UNIVERSIDADE DE SÃO PAULO

INSTITUTO DE GEOCIÊNCIAS

\title{
CARACTERIZAÇÃO METAMÓRFICA E GEOCRONOLÓGICA DAS ROCHAS PROTEROZÓICAS DO MACIÇO DE GARZÓN - SUDESTE DOS ANES DA COLÔMBIA
}

\author{
DIANA MARIA JIMÉNEZ MEJÍA
}

Orientador: Prof. Dr. Umberto Giuseppe Cordani

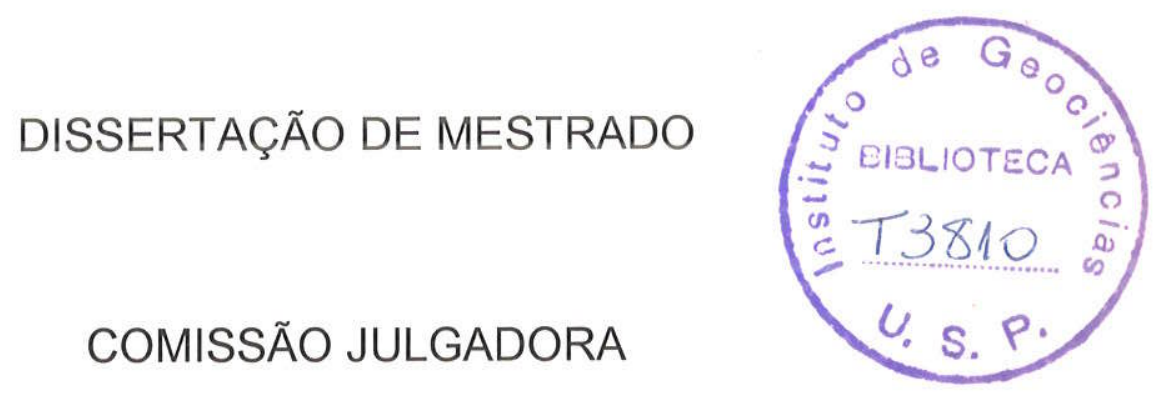

Nome

Assinatura

Presidente: Prof. Dr. Umberto Giuseppe Cordani

Examinadores: Prof. Dr. Marcos Aurélio Farias de Oliveira

Prof. Dr. Mario da Costa Campos Neto

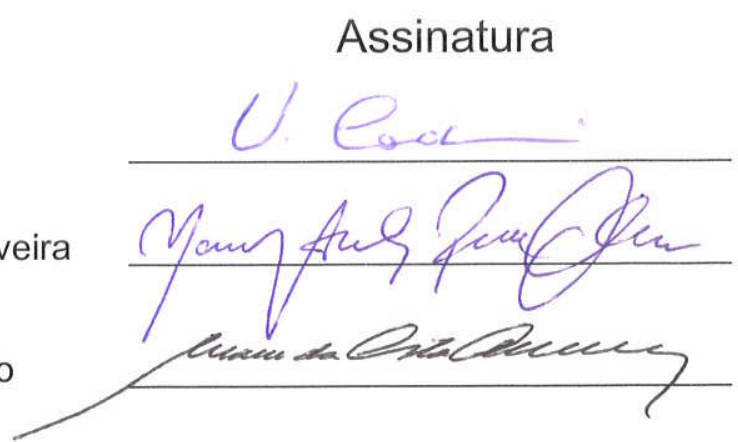

SÃO PAULO

2003 


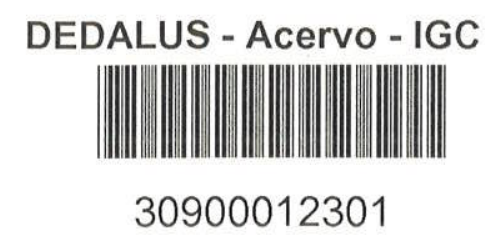

UNIVERSIDADE DE SÃO PAULO INSTITUTO DE GEOCIÊNCIAS

\section{* CARACTERIZAÇÃo METAMÓRFICA E GEOCRONOLÓGICA DAS ROCHAS PROTEROZÓICAS DO MACIÇO DE GARZÓN - SUDESTE DOS ANDES DA COLÔMBIA}

Diana Maria Jiménez Mejía

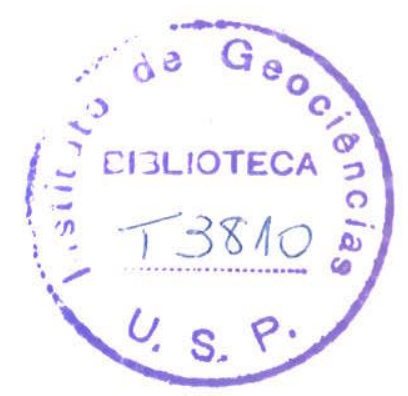

Orientador: Prof. Dr. Umberto Giuseppe Cordani

$$
\text { DISSERTAÇÃO DE MESTRADO }
$$

Programa de Pós-Graduação em Geoquímica e Geotectônica

SÃO PAULO

2003 


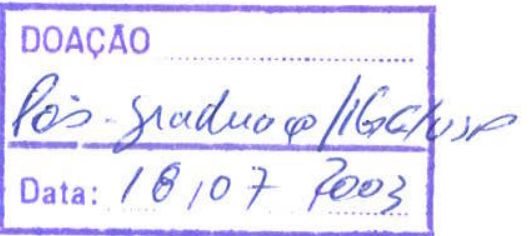

A Javier y a nuestra hija Paula Andrea

Por el apoyo incondicional de ambos, fuerza en los momentos dificiles, y el profundo amor recibido que fue el motor inspirador. 


\section{AGRADECIMENTOS}

A meu orientador Prof. Dr. Umberto Cordani por brindar-me com a oportunidade de realizar estudos de pós-graduação e pelo apoio recebido ao longo deste processo de formação acadêmica.

A INGEOMINAS e a os subdiretores Georgina Guzman e Fernando Muñoz pela comissão de estudos otorgada, pelas amostras cedidas e pelas folhas geológicas que serviram de base para a realização desta pesquisa. Em especial gostaria de agradecer à geologa Gloria Ines Rodríguez e Mayeli Gomez pelo apoio na petrografia, e aos geologos, Jose Fernando Osorno, Jaime Alberto Fuquen, Germán Marquinez, Francisco Velandia, Eduardo Lopez e Alberto Nuñez.

Ao Instituto de Geociências da Universidade de São Paulo pela formação acadêmica recebida e pelo apoio logístico de sua estrutura laboratorial. A seus professores pelas orientações oportunas em muitas disciplinas, especialmente aos Profs Drs: Colombo Tassinari, José Moacyr Couthinho, Kei Sato, Silvio Vlach e a Caetano Guliani.

Ao Prof. José Munhá pelas orientações práticas em petrologia e geotermobarometria.

Ao pessoal técnico do Centro de Pesquisas Geocronológicas da USP, Helen, Ivone, Liliane, Mitzi, Vasco, Vera, Veridiana, Solange, e Arthur pela colaboração na parte de preparação das amostras e nas diversas técnicas analíticas da geocronologia, e a Marcos, do Laboratório de Microssonda.

Aos colegas, especialmente Agustín pelas discussões enriquecedoras, e a Tatiana, Victor, Zibeli, Anabel, Cely, Leonardo pela amizade e ajuda no decorrer da pesquisa.

A Liu Dunyi da Academia Chinesa de Ciências Geológicas pelas análises de U/Pb SHRIMP em zircão.

A Javier pela colaboração na edição do trabalho final 


\section{SUMÁRIO}

Dedicatória

Agradecimentos

Lista de figuras

iii

Lista de tabelas

vii

Lista de quadros

viij

Lista de pranchas

ix

Resumo

xii

Abstract

xiii

1 INTRODUÇÃO

1.1 Objetivos específicos

1.2 Localização da área

2 GEOLOGIA

2.1 Geotectônica: generalidades e arcabouço 4

2.2 Histórico dos trabalhos geológicos no Maciço de Garzón 6

2.3 Dados geocronológicos existentes 8

2.4 Correlaçōes regionais previas 9

2.5 Geologia local $\quad 12$

2.5.1 Gnaisse de Guapotón-Mancagua 13

2.5.2 Complexo Garzón 14

2.5.2.1 Granulitos do Vergel $\quad 15$

2.5.2.2 Gnaisse das Margaritas 16

$3 \quad$ PETROLOGIA E ASPECTOS DO METAMORFISMO 19

3.1 Gnaisse de Guapotón-Mancagua 19

3.2 Granulitos do Vergel $\quad 20$

3.3 Gnaisse das Margaritas $\quad 22$

4 GEOTERMOBAROMETRIA $\quad 27$

4.1 Métodos geotermobarométricos $\quad 27$

4.2 Granulitos do Vergel 29

4.2.1 Química mineral $\quad 29$

4.2.2 Resultados geotermobarométricos 31 
4.3 Gnaisse das Margaritas 33

4.3.1 Química mineral 34

4.3.2 Resultados geotermobarométricos 37

4.4 Considerações geotermobarométricas 42

5 METODOLOGIAS GEOCRONOLÓGICAS 44

5.1 Análises U-Pb em zircão 44

5.1.1 Separação mineral e procedimento analítico 45

5.2 Análises $\mathrm{Sm}-\mathrm{Nd} \quad 46$

5.2.1 Preparação das amostras e procedimento analítico 48

5.3 Análises $\mathrm{Rb}-\mathrm{Sr} \quad 48$

5.3.1 Preparação das amostras e procedimento analítico 50

5.4 Análises Ar-Ar $\quad 50$

6 INTERPRETAÇÃO DOS DADOS GEOCRONOLÓGICOS 52

6.1 Datações U-Pb em zircão 52

$\begin{array}{lll}6.2 & \text { Sistemática Sm-Nd } & 59\end{array}$

5.2.3 Geoquímica isotópica $\mathrm{Rb}-\mathrm{Sr} \quad 64$

5.2.4 Datações Ar-Ar em minerais separados $\quad 71$

7 CARACTERIZAÇÃO GEOTECTÔNICA DO MACIÇO DE GARZÓN 88

7.1 Evolução tectono-metamórfica 88

7.2 Correlações regionais e participação no supercontinente de Rodínia 95

REFERÊNCIAS BIBLIOGRÁFICAS $\quad 99$

\begin{abstract}
ANEXOS
Anexo 1 - Mapa geológico com localização das amostras estudadas

Anexo 11 - Características gerais dos minerais das rochas regionais do Maciço de Garzón

Anexo III - Análises de microssonda eletrônica e composição mineralógica

Anexo IV - Lista de abreviações para minerais formadores de rochas

Anexo V - Descrição petrográfica das amostras utilizadas para as análises geotermobarométricas e isotópicas

Anexo VI - Dados isotópicos U-Pb SHRIMP em zircão

Anexo VII - Dados analíticos ${ }^{40} \mathrm{Ar} /{ }^{39} \mathrm{Ar}$
\end{abstract}




\section{LISTA DE FIGURAS}

FIGURA 1 Mapa de localização

FIGURA 2 Províncias geográficas da Colômbia 5

FIGURA 3 Diagramas ACFN de coexistência de hornblenda em rochas de transição de fácies anfibolito-granulito, tomados de SPEAR (1985) para rochas máficas ricas em $\mathrm{Fe}$ onde são mostradas as associações $\mathrm{Hbl}+\mathrm{Grt}+\mathrm{Opx}+\mathrm{Pl}, \mathrm{Hbl}+\mathrm{Grt}+\mathrm{Cpx}+\mathrm{Pl}$ e $\mathrm{Hbl}+\mathrm{Grt}+\mathrm{Cpx}+\mathrm{Opx}$

FIGURA 4 Composição da granada do granulito charnockítico V-332: = núcleo e posições intermediárias, $=$ borda em contato com biotita.

FIGURA 5 Perfil composicional da granada V-332: análises: $15=$ contato granadabiotita, 18 e $21=$ posições intermediárias, $19=$ núcleo, e $20=$ borda

FIGURA 6 Classificação do ortopiroxênio do granulito charnockítico V-332, análises 1-11 no perfil px-grt1: $=$ núcleo e posições intermediárias, $\quad$ = borda emcontato com granada, $=$ alteração.

FIGURA 7 Composição dos feldspatos do granulito charnockítico V-332: ortoclásio pertítico, $\quad=$ pertita, $\nabla=$ contato plagioclásio-granada, $=$ núcleo do plagioclásio.

FIGURA 8 Diagrama Ti/Al das biotitas do granulito charnockítico V-332: = inclusão em granada, $\%=$ núcleo e posições intermediárias, $\nabla=$ borda em contato com granada, 0 = formada pela quebra de granada e piroxênio.

FIGURA 9 Diagrama P-T do granulito charnockitico V-332 dos Granulitos do Vergel obtido com o TWQ do intercepto das reações entre plagioclásioortopiroxênio-granada-biotita-quartzo. Ponto triplo $\mathrm{Al}_{2} \mathrm{SiO}_{5}$ de HOLDAWAY(1971). As setas indicam a trajetória anti-horária.

FIGURA 10 Resultados dos cálculos TWQ da associação mineral em equilíbrio V332-1do granulito charnockítico, usando os núcleos da granada, biotita, ortopiro-xênio e borda do plagioclásio em contato com granada, mais quartzo.

FIGURA 11 Composição da granada do quartzo-plagioclásio gnaisse Gr-15: $\nabla=$ borda em contato com biotita, $=$ núcleo e posições intermediárias.

FIGURA 12 Perfil composicional da granada do quartzo-plagioclásio gnaisse Gr-15: análises $3=$ contato granada-biotita, 1,2 e $4=$ núcleo e posições intermediárias.

FIGURA 13 Composição da granada do gnaisse migmatítico Z-365-1: = contato granada-plagioclásio, $\nabla=$ contato granada-biotita, $\nabla=$ núcleo e posições intermediárias.

FIGURA 14 Perfil composicional da granada do gnaisse migmatítico Z-365-1: análises $1-3=$ núcleo, $4=$ contato granada-biotita, $6=$ borda . 
FIGURA 15 Diagrama TI/AI das biotitas do quartzo-plagioclásio gnaisse $\mathrm{Gr}-15: \mathrm{F}=$ biotita verde do núcleo, $=$ biotita verde em contato com granada, $=$ biotita simplectítica do núcleo, $\quad=$ biotita simplectítica em contato com granada,. =biotita da matriz, = biotita cloritizada.

FIGURA 16 Diagrama Ti/AI das biotitas do gnaisse migmatítico Z-365-1, $\mathrm{E}=$ = biotita associada à sillimanita, 0 biotita da matriz, $\mathrm{p}=$ núcleo e posiçőes intermediárias, $\nabla=$ contato granada-biotita.

FIGURA 17 Composição da granada do granulito máfico C-32: = contato granadaortopiroxênio, $O=$ granada em contato com inclusão de biotita, $\square=$ contato granada biotita, $=$ núcleo e posições intermediarias, $+=$ inclusão de granada em ortopiroxênio, $\diamond=$ contato granada hornblenda.

FIGURA 18 Perfil composicional da granada do granulito máfico $\mathrm{C}_{-32}$ : análises 29 =contato granada-ortopiroxênio, 30,31,32 e $35=$ posições intermediarias e núcleo, 33 e 34 = contato granada-inclusão de biotita.

FIGURA 19 Diagrama Ti/AI de todas as biotitas C-32, = inclusões em granada, $=$ contato biotita piroxênio, $\nabla=$ contato biotita granada,$\quad=$ núcleo $e$ posições intermediarias, $0=$ contato biotita hormblenda , $=$ biotita sindeformação.

FIGURA 20 Composição do anfibólio do granulito máfico $\mathrm{C}-32$ = anfibólio em contato com biotita, $=$ núcleo e posições intermediarias.

FIGURA 21 Diagrama P-T do granulito máfico, gnaisse migmatítico, e quartzoplagioclásio gnaisse pertencentes ao Gnaisse das Margaritas obtido com - TWQ.1) reação de fusão-desidratação $\mathrm{bt}+\mathrm{pl}+\mathrm{Al}_{2} \mathrm{SiO}_{5}+q \mathrm{tz}=$ grt+kfsl+fundido de LE BRETON \& THOMPSON $(1988)$, 2) reação $m s+a b+q t z=k f s+s i l+L$ de PETÖ(1976) apud LE BRETON \& THOMPSON (1988), 3) Curva de cristalização do granito de HUANG \& WYLLIE (1973) apud LE BRETON \& THOMPSON (1988). Ponto triplo $\mathrm{Al}_{2} \mathrm{SiO}_{5}$ de HOLDAWAY (1971). A seta indica a trajetória de descompressão aproximadamente isotérmica-ITD (near-isothermal decompression) em sentido horário.

FIGURA 22 Resultados dos cálculos TWQ da associação mineral Z-365-12 do gnaisse migmatítico, usando a paragênese granada-sillimanita-biotitafeldspato potássico-quartzo.

FIGURA 23 Resultados dos cálculos TWQ da associação mineral C-32-7 do granulito máfico, usando os núcleos da granada, ortopiroxênio e plagioclásio, inclusões de biotita mais quartzo.

FIGURA 24 Diagrama Concórdia do ortognaisse V-198.

FIGURA 25 Imagens de catodoluminiscência do ortognaisse V-198, análises de núcleo em amarelo e de bordas em vermelho; observa-se núcleo e borda do zircão

FIGURA 26 Diagrama Concórdia do granulito enderbítico Gr-29. 
FIGURA 27 Diagrama Tera-Wasserburg do granulito enderbítico Gr-29.

FIGURA 28 Diagrama Concórdia do quartzo-feldspato-biotita gnaisse (leucossoma 2de injeção, amostra Gr-15a).

FIGURA 29 Diagrama Tera-Wasserburg do granodiorito gnáissico A-746.

FIGURA 30 Imagens de catodoluminiscência do granodiorito gnáissico A-746.

FIGURA 31 Isócronas Sm-Nd em rocha total e granada do granulito charnockítico V332 e do quartzo-feldspato gnaisse D-982, pertencentes aos Granulitos do Vergel.

FIGURA 32 Isócronas Sm-Nd em rocha total e granada do biotita-granada gnaisse Gr-15p e do granulito máfico C-32, pertencentes ao Gnaisse das Margaritas.

FIGURA 33 Isócrona Sm-Nd em rocha total, plagioclásio e piroxênio do granulito enderbítico Gr-29, pertencente aos Granulitos do Vergel.

FIGURA 34 Gráfico $T_{D M}$ das rochas do Maciço de Garzón. Inclui as rochas V-198, V314, Gr-29b e d, V-332, D-982, C-32 e Gr-15a deste trabalho em azul, e as HP-3 e SnAnKr-1 de RESTREPO-PACE (1995) em verde.

FIGURA 35 Diagrama Isocrónico $\mathrm{Rb}-\mathrm{Sr}$ em rocha total das amostras regionais do Maciço de Garzón. Inclui dados isotópicos desta pesquisa (amostras Gr29, Gr-29a, b, d, e, f, h, i, D-806 a,b,c, V-332, D-982, V-314, V-290, Gr-15 A, Gr-15p e V-198), de ALVAREZ (1981 a) (JAA-1174,1177,1179 e 1180), e de PRIEM et al. (1989) ( CIA-1, 3, 10, 14)

FIGURA 36 Gráfico $\epsilon_{\mathrm{Nd}} / \epsilon_{\mathrm{Sr}}$ para as amostras do Maciço de Garzón. As rochas dos Granulitos do Vergel estão em azul, do Gnaisse das Margaritas em verde, e do Gnaisse de Guapotón-Mancagua em vermelho.

FIGURA 37 Diagrama isocrônico Rb-Sr para as amostras cogenéticas de rocha total Gr-29 e Gr-29a,b, d, e, f, h, i pertencentes aos Granulitos do Vergel.

FIGURA 38 Isócrona $\mathrm{Rb}-\mathrm{Sr}$ em rocha total, plagioclásio e biotita da amostra Gr-29 pertencente ao Granulitos do Vergel.

FIGURA 39 Isócrona $\mathrm{Rb}-\mathrm{Sr}$ em rocha total das amostras do granulito bandado D$806 \mathrm{a}, \mathrm{b}, \mathrm{c}$ pertencentes aos Granulitos do Vergel.

FIGURA 40 Espectro de degaseificação da hornblenda, amostra V-198.

FIGURA 41 Espectro de degaseificação da biotita, amostra V-198.

FIGURA 42 Espectro de degaseificação da biotita, amostra V-332.

FIGURA 43 Espectro de degaseificação da biotita, amostra Gr-29.

FIGURA 44 Ideogramas para os grãos das biotitas das amostras Gr-29 e V-332 . 
FIGURA 45 Espectro de degaseificação da biotita, amostra D-982. 76

FIGURA 46 Espectro de degaseificação da hornblenda, amostra D-986. 77

FIGURA 47 Espectro de degaseificação da biotita, amostra D-986. 77

FIGURA 48 Espectro de degaseificação da hornblenda, amostra V-309. 78

FIGURA 49 Ideograma para os grãos da hornblenda, amostra V-309 78

FIGURA 50 Espectro de degaseificação da biotita, amostra V-309. 79

FIGURA $51 \quad$ Ideograma para os grãos da biotita, amostra V-309. 79

FIGURA 52 Espectro de degaseificação da biotita, amostra C-302. 80

FIGURA 53 Ideograma para os grãos da biotita, amostra C-302. 80

FIGURA 54 Espectro de degaseificação da biotita, amostra C-271. 81

FIGURA 55 Ideograma para os grãos da biotita, amostra C-271. 81

FIGURA 56 Espectro de degaseificação da hornblenda, amostra C-299. 81

FIGURA 57 Espectro de degaseificação da biotita, amostra C-299. 82

FIGURA 58 Ideograma para os grãos da biotita, amostra C-299. 82

FIGURA 59 Espectro de degaseificação da hornblenda, amostra C-32. 83

FIGURA 60 Ideograma para os grãos da hornblenda, amostra C-32. 83

FIGURA 61 Espectro de degaseificação da biotita, amostra C-32. 84

FIGURA 62 Ideograma para os grãos da biotita, amostra C-32. 84

FIGURA 63 Espectro de degaseificação da biotita, amostra Gr-15p. 84

FIGURA 64 Ideograma para os grãos da biotita, amostra Gr-15p. 85 .

FIGURA 65 Espectro de degaseificação da hornblenda, amostra A-746. 86

FIGURA 66 Espectro de degaseificação da biotita, amostra A-746. 86

FIGURA 67 Ideograma para os grãos da biotita, amostra A-746. 87

FIGURA 68 Diagrama T-t para os Granulitos do Vergel. 94

FIGURA 69 Diagrama T-t para o Gnaisse das Margaritas. 94 


\section{LISTA DE TABELAS}

TABELA 1 Idades U-Pb SHRIMP em zircão de amostras do Maciço de Garzón e Complexo Migmatítico da Cocha Rio Tellez.

TABELA 2 - Análises $\mathrm{Sm-Nd} \mathrm{em} \mathrm{rocha} \mathrm{total} \mathrm{e} \mathrm{mineral} \mathrm{de} \mathrm{amostras} \mathrm{do} \mathrm{Maciço} \mathrm{de}$ Garzón

TABELA 3 - Análises Rb-Sr em rocha total e mineral de amostras do Maciço de Garzón

TABELA 4 - Idades Ar-Ar em biotita e hornblenda de amostras do Maciço de Garzón e do Complexo Migmatítico da Cocha Rio Tellez 


\section{LISTA DE QUADROS}

QUADRO 1 Geocronologia e geoquímica isotópica de rochas do Maciço de Garzón.

QUADRO 2 Nomenclatura estratigráfica do Maciço de Garzón.

QUADRO 3 Fácies e paragêneses metamórficas das rochas do Complexo Garzón.

QUADRO 4 Temperaturas e Pressões médias das associações núcleo e borda da Lâmina V-332 obtidas por geotermobarometria clássica.

QUADRO 5 Composições médias dos núcleos das granadas do Gnaisse das Margaritas, lâminas Gr-15, Z-365 e C-32.

QUADRO 6 Temperatura média das associações núcleo $(\mathrm{n})$ da lâmina Gr-15 obtidas por geotermobarometria clássica.

QUADRO 7 Temperatura média das associações núcleo (n) da lâmina Z-365 obtidas por geotermobarometria clássica.

QUADRO 8 Temperaturas e Pressões médias das associações núcleo ( $\mathrm{n}$ ) e borda (b) da lâmina C-32, obtidas por geotermobarometria clássica.

QUADRO 9 Resumo dos eventos tectono-magmáticos reconhecidos no Maciço de Garzón nesta pesquisa 


\section{LISTA DE PRANCHAS}

PRANCHA 1.

FOTO 1. Gnaisse quartzo-feldspático com hornblenda e biotita. Observam-se os cristais augen de $k$-feldspato e quartzo (INGEOMINAS \& GEOESTUDIOS, 2001 a).

FOTO 2. Granulitos com bandas félsicas e máficas (INGEOMINAS \& GEOESTUDIOS, 2001 a).

FOTO 3. Seqüência migmatítica constituída por intercalações de quartzo plagioclásio-biotita gnaisses cinza (mesossoma) e granito gnaisses rosa pálido (leucossoma 2). O mesossoma esta assimilado pelo leucossoma 2. Boudins de anfibolitos cinza escuros intercalam-se nos migmatitos. O granito pegmatito rosa (leucossoma 3) corta o migmatito e está deslocado por uma falha dextral.

FOTO 4. Metatexito constituído por biotita gnaisses escuros e quartzo-plagioclásio gnaisses com granada (leucossoma 1). O leucossoma 2 injeta o metatexito.

FOTO 5. Bolsões de quartzo-plagioclásio gnaisse (leucossoma 1) em biotita gnaisse escuro. A granada está concentrada nas segregações leucocráticas.

FOTO 6. Detalhe do quartzo-feldspato gnaisse cinza injetado pelo granito gnaisse rosa pálido (leucossoma 2).

FOTO 7. Migmatito dobrado constituído por intercalações estromáticas de quartzo feldspato-biotita gnaisses cinza e quartzo-feldspato gnaisses rosa. Outra geração de gnaisses rosa preenchem o eixo da dobra e desenvolvem estrutura ptigmática.

FOTO 8. Detalhe do pegmatito com biotita de até $10 \mathrm{~cm}$ de comprimento (leucossoma 3).

PRANCHA 2.

FOTO 1 Associação mineral ortopiroxênio-plagioclásio-biotita-hornblenda do plagioclásio-quartzo gnaisse com biotita. Hornblenda formada pela quebra do ortopiroxênio. Nícois paralelos, lâmina C-299.

FOTO 2. K-feldspato mesopertítico do granulito charnockítico. Observa-se a deformação do k-feldspato, lâmina V-332.

FOTO 3. Pertitas flame de substituição desenvolvidas na borda do k-feldspato em contato com plagioclásio, lâmina Z-365-2. 
FOTO 4. Plagioclásio mirmequítico entre cristais do k-feldspato pertítico. Observa-se os dois sets de pertitas no k-feldspato, uma muito fina regular e a outra mais grossa e elipsoidal, lâmina D-806.

FOTO 5. Granada com inclusões arredondadas de quartzo; nas margens contatos lobados com quartzo. Feições típicas de metamorfismo prógrado. Lâmina Gr-15.

FOTO 6. Metatexito constituído por melanossoma (Me) e leucossoma 1, (Le), lâmina Z-365. O melanossoma consiste de quartzo, ortoclásio pertítico, plagioclásio e biotita sem orientação preferencial. O leucossoma 1 fino consiste de quartzo, microclínio, granada e biotita. Níveis máficos (M) de sillimanita e biotita seguindo a segunda foliação cortam o mesossoma.

FOTO 1. Detalhe da associação sillimanita e biotita da lâmina Z 365. A sillimanita altera-se a argila e entre os interstícios dos cristais de biotita gera-se moscovita em condições retrógradas.

FOTO 2. Detalhe do leucossoma 1 da lâmina Z-365. Granada com inclusões de sillimanita, esta última como resquício de uma fase mineral pre-migmatítica.

FOTO 3. Detalhe do leucossoma 1 da lâmina Z-365. K-feldspato com inclusão de sillimanita, esta última como resquício de uma fase mineral pre-migmatítica. O k-feldspato inverte-se a microclínio nas bordas do cristal.

FOTO 4. Simplectitas de biotita e plagioclásio formadas às expensas da granada e microclínio. O arranjo simplectítico está reabsorvendo a granada. Nícois paralelos, lâmina Gr-15.

FOTO 5. Simplectitas de biotita e plagioclásio formadas às expensas da granada e microclínio. $O$ arranjo simplectítico está reabsorvendo a granada. Nícois cruzados, lâmina Gr-15.

FOTO 6. Detalhe da simplectita, lâmina Gr-15. Borda de plagioclásio ao redor da granada restante da reação entre k-feldspato, granada, biotita, plagioclásio e quartzo mais água.

FOTO 7. Plagioclásio antipertítico com desenvolvimento de pertitas em duas direções refletindo processos diferentes. As pertitas sub-horizontais seguem a direção da biotita (indicada pela seta) formada durante a segunda foliação do granulito. Lâmina C-32.

FOTO 8 Desenvolvimento de biotita (Bt2) e plagioclásio (PI2) numa segunda foliação, bordejando o plagioclásio (PI1). O plagioclásio (Pl1) faz parte da associação mineral granulítica (Grt-Opx-Hbl-PI-Qtz) desta rocha máfica. Lâmina C-32 


\section{RESUMO}

Maciço de Garzón, ao sudeste dos Andes da Colômbia, contém uma zona bem exposta de rochas metamórficas de alto grau na transição anfibolito-granulito, constituída pelas seguintes unidades, de oeste para leste: Gnaisse de Guapotón-Mancagua, Granulitos do Vergel e o Gnaisse das Margaritas.

Trajetórias geotermobarométricas P-T das rochas metamórficas de alto grau integradas com dados geocronológicos U-Pb SHRIMP em zircão, Sm-Nd em rocha total e mineral, Rb-Sr em rocha total e mineral e Ar-Ar em biotita e hornblenda, permitiram caracterizar dois eventos tectonotermais relacionados com magmatismo de arco e orogênese colisional posterior.

O Gnaisse de Guapotón-Mancagua, registra idades de $1148 \pm 69 \mathrm{Ma}$ e $1005 \pm 26 \mathrm{Ma}$ através de resultados U-Pb SHRIMP em zircão, relacionadas com a sua evolução em arco magmático e deformação tectônica posterior em condições de fácies anfibolito.

As rochas do Gnaisse das Margaritas apresentam condições máximas de metamorfismo de aproximadamente $8 \mathrm{kbar}$ e $780^{\circ} \mathrm{C}$ e trajetória retrógrada $\mathrm{ITD}$, em sentido horário. $\mathrm{O}$ retrometamorfismo foi acompanhado por extensa migmatização relacionada com fusão parcial insaturada em água, e geração local de leucossomas de injeção. Deformação posterior em condições de alto grau deu lugar a uma foliação milonítica. Os resultados geocronológicos indicam idade minima do metamorfismo de $1034 \pm 6 \mathrm{Ma}$ (Sm-Nd em RTgranada), enquanto que o leucossoma de injeção fornece idade de $1006 \pm 6.4 \mathrm{Ma}$ (U-Pb SHRIMP em zircão). As idades de resfriamento Ar-Ar em hornblenda e biotita, próximas a $1000 \mathrm{Ma}$, sugerem taxas moderadas de resfriamento em torno de $3.5^{\circ} \mathrm{C} / \mathrm{Ma}$. A evolução tectônica desta unidade estaria relacionada a espessamento crustal inerente a um processo de subducção tipo $B$, o qual também teria formado os protolitos do Gnaisse de GuapotónMancagua. Posteriormente um evento colisional acarretou a trajetória retrógrada observada.

Em contraste, os Granulitos do Vergel apresentam metamorfismo de aproximadamente 6 kbar e $700^{\circ} \mathrm{C}$ e trajetória anti-horária relacionada ao re-equilibrio após metamorfismo prógrado. A época do metamorfismo desta unidade encontra-se próxima a $1000 \mathrm{Ma}$, obtida da sistemática SHRIMP U-Pb em zircão metamórfico e Sm-Nd em rocha total-granada. A trajetória de resfriamento teria sido caracterizada inicialmente por taxas baixas $\left(2.8^{\circ} \mathrm{C} / \mathrm{Ma}\right)$ entre 1000 e $930 \mathrm{Ma}$ (Sm-Nd em rocha total-granada), seguido por taxas mais rápidas de $23^{\circ} \mathrm{C} / \mathrm{Ma}$ de acordo com as idades aparentes Ar-Ar em biotita de $917 \pm 3 \mathrm{Ma}$. A trajetória 
anti-horária pode estar relacionada ao reajuste orogênico associado com fase colisional, o que teria permitido o desencadeamento das falhas de empurrão que justapõem esta unidade contra o Gnaisse das Margaritas e causado reaquecimento posterior, responsável pela obliteração da história isotópica inicial.

As idades modelo Sm-Nd $\mathrm{T}_{\mathrm{DM}}(1.4$ e $2.0 \mathrm{Ga})$, integradas com indicadores petrogenéticos de $\mathrm{Sr}$ e Nd de todas as unidades, sugerem que os protolitos foram formados em domínio crustal altamente evoluído, caracterizado pela mistura de componentes mesoproterozóicos juvenís com componentes crustais mais velhos.

O registro litoestratigráfico, metamórfico e isotópico $\mathrm{Sm}-\mathrm{Nd}$ das rochas do Maciço de Garzón tem semelhança com o de outros domínios proterozóicos dos Andes Setentrionais da Colômbia (Guajira, Santa Marta, Santander), sugerindo a presença de processos similares e uma evolução tectônica comum. Além disso, as rochas proterozóicas do terreno Oaxaquia, no México, apresentam tanto magmatismo de arco, como metamorfismo de alto grau com idades similares às determinadas no Maciço de Garzón, o que sugere uma estreita relação genética.

Além disso, as características metamórficas de alto grau e as idades dos domínios proterozóicos da Colômbia, México e Andes do Sul (Peru, Chile e Argentina) são também correlacionáveis com a Provincia Grenville da América do Norte, o que sugere que estes domínios do embasamento são peças importantes do extenso cinturão orogênico que participou da aglutinação do Supercontinente Rodínia. 


\begin{abstract}
The Garzon Massif in the south-eastern Colombian Andes is made up by an extensive highgrade metamorphic zone at the amphibolite-granulite facies transition, and can be divided from west to east in three main informal lithostratigraphic units (Guapoton-Mancagua Gneiss, Vergel Granulite and Las Margaritas Gneiss).
\end{abstract}

Geotermobarometric P-T paths for the high grade metamorphic rocks, integrated with zircon $\mathrm{U}-\mathrm{Pb}$ SHRIMP, Sm-Nd mineral-whole rock, $\mathrm{Rb}-\mathrm{Sr}$ mineral-whole rock, and Ar-Ar hornblendebiotite ages show two metamorphic events related to arc magmatism and late collision orogeny.

Zircon U-Pb SHRIMP geochronology from the Guapotón-Mancagua Gneiss records $1148 \pm$ $69 \mathrm{Ma}$ and $1005 \pm 26 \mathrm{Ma}$ ages related to the magmatic evolution and tectonic deformation in the amphibolite facies.

Rocks from Las Margaritas Gneiss show metamorphic peak conditions around 8 kbar and $780^{\circ} \mathrm{C}$, and a retrograde ITD clockwise path associated with migmatization formed in insaturated partial fusion conditions, with generation of an injection leucosome and a later high grade milonytic foliation. Geochronological contraints indicate a minimum metamorphic age close to $1034 \pm 6 \mathrm{Ma}$ ( $\mathrm{Sm}$-Nd in RT-garnet), whereas a late metamorphic leucosome shows $1006 \pm 6.4 \mathrm{Ma}$ (zircon U-Pb SHRIMP). Biotite-hornblende Ar-Ar cooling ages are close to $1000 \mathrm{Ma}$, and may be related to slow cooling rates around $3.5^{\circ} \mathrm{C} / \mathrm{Ma}$. The tectonic evolution of this unit was probably related to B-type subduction and the crustal thickening that also formed the Guapoton-Mancagua protoliths, followed by a collisional event that caused the observed retrograde path.

In contrast, the Vergel Granulites present metamorphic conditions around 6 kbar e $700^{\circ} \mathrm{C}$ and a counter-clockwise path related to re-equilibrium after the prograde metamorphism. The age of this metamorphism is temporally constrained at $1000 \mathrm{Ma}$ (zircon U-Pb SHRIMP and whole-rock Sm-Nd). Cooling path is characterized by slow initial $\left(2.8^{\circ} \mathrm{C} / \mathrm{Ma}\right)$ rates between 1000-930 Ma, followed by a faster $23^{\circ} \mathrm{C} / \mathrm{Ma}$ rate as shown by the $917 \mathrm{Ma}$ biotitehornblende Ar-Ar apparent ages. The counter-clockwise path can be related to an orogenic re-adjustment associated to a late collisional phase that also produced internal thrust faults juxtaposing the unit against the Las Margaritas Gneiss, and causing a late re-heating obliterating the isotopic history. 
Sm-Nd $\mathrm{T}_{\mathrm{DM}}$ model ages $(1.4$ e $2.0 \mathrm{Ga}$ ), integrated with Sr-Nd petrogenetic data suggest that the protoliths of the regional rock units where formed in a highly evolved crustal domain, characterized by a mixture of juvenile mesoproterozoic material plus older crustal components.

The lithostratigraphic, metamorphic and $\mathrm{Sm}-\mathrm{Nd}$ isotopic record of the rocks from the Garzon Massif bear similarities with other proterozoic domains within the northern Colombian Andes (Guajira, Santa Marta, Santander), suggesting the presence of similar geological processes and a common tectonic evolution. Additionally, the proterozoic rocks from the Mexican Oaxaquia terrain record both arc magmatism and high-grade metamorphic phases present in the Garzón Massif, suggesting a close correlation.

The high grade metamorphic characteristic of the proterozoic domains from Colombia, Mexico and the southern Andes (Peru, Chile e Argentina) of similar age can be correlated with the North American Grenville Province. This basement domains can be considered important pieces of the orogenic belt that took part of the agglutination of the Rodinia Supercontinent. 


\section{INTRODUÇÃO}

Na região Andina da Colômbia estão expostos de maneira segmentada uma serie de domínios crustais (maciços de Garzón, Santander, Santa Marta, e Guajira) cujas idades radiométricas disponiveis estão entre 900 e $1200 \mathrm{Ma}$. Destes, o Maciço de Garzón, o mais meridional, corresponde à maior exposição de rochas do embasamento, e é o que melhor preserva a historia Mesoproterozóica. Em outras palavras, a complexa atividade tectônica superposta desde seu geração até a formação da cadeia Andina não consegue obliterar o registro mais antigo.

Nesta pesquisa são apresentados dados geotermobarométricos, geocronológicos e isotópicos (U/Pb SHRIMP, Rb-Sr, Sm-Nd e Ar-Ar) desse maciço visando caracterizar os principais eventos tectônicos, e desta forma compreender a sua evolução geológica. Alem disto, pretende-se identificar o caráter geral dos processos relacionados à gênese das rochas para sua correlação temporal com os domínios mais a norte na Colômbia e com o domínio localizado ao sul da sutura Ouachita do México. O conhecimento particular dos principais eventos tectono-magmáticos do Maciço de Garzón traz novos elementos de juízo para as correlações globais com outros domínios formados durante a orogênese de idade Grenvilliana, uma vez que Garzón e os demais dominios foram sido formados durante sucessivas fases de colisão de placas, e têm sido considerados peças importantes na reconstrução do Supercontinente Rodínia (DALZIEL, 1997; SADOWSKY \& BETTENCOURT, 1996; TOSDAL, 1996, entre outros).

Terrenos metamórficos de alto grau proporcionam uma boa oportunidade para definir as trajetórias P-T devido à disponibilidade de geotermobarômetros. Porém, para uma historia geológica completa, é necessário caracterizar os caminhos do metamorfismo com a informação do tempo em que os processos tectônicos aconteceram (MEZGER, 1990). Neste sentido as ferramentas geocronológicas de alta precisão, como as datações, U/Pb em zircão, permitem obter informação da cristalização magmática ou recristalização metamórfica, e desta forma sugerir o tipo de ambiente geológico que precedeu o ápice das condições metamórficas. A historia do metamorfismo prógrado nem sempre fica gravada na memória dos minerais empregados nas análises geotermobarométricas, especialmente para as rochas metamórficas na fácies anfibolito superior ou granulito. $\mathrm{O}$ cronômetro $\mathrm{Sm} / \mathrm{Nd}$ em granada pode indicar as condições próximas ao pico metamórfico (MEZGER et al., 1992). Finalmente, a historia da exumação e do resfriamento do orógeno é obtida pelas idades Ar-Ar em micas, de acordo com a respectiva temperatura de fechamento (DODSON, 1973; MCDOUGALL \& HARRISON, 1999). 
A obtenção destas idades de resfriamento, alem de dar informação relativa do soerguimento, permitem também determinar o possivel levantamento diferencial entre os blocos de um orógeno (RIDLEY, 1989).

\subsection{Objetivos especificos}

Os objetivos específicos desta pesquisa são:

- Obter dados geotermobarométricos das unidades metamórficas para caracterizar o metamorfismo e a história geológica, por meio das trajetórias P-T.

- Determinar traçadores de tempo em vários estágios do caminho P-T das rochas por meio da geocronologia:

- por meio de dados U/Pb SHRIMP em zircão obter o tempo em que os eventos pré e sin-orogenéticos aconteceram.

- por meio de dados Sm-Nd e Rb-Sr determinar o ápice dos principais eventos tectonometamórficos.

- por meio de dados isotópicos de Sr e Nd caracterizar, de maneira geral, os principais processos atuantes na formação das rochas (participação do manto ou retrabalhamento crustal).

- por meio de dados isotópicos Ar-Ar em hornblenda e biotita, obter informação da história do resfriamento e da exumação dos blocos tectônicos.

- Finalmente, o conjunto de dados geotermobarométricos, geocronológicos e isotópicos poderá permitir correlações gerais com os dominios congêneres dos Andes Setentrionais e do Cinturão de Grenville.

\subsection{Localização da área}

O Maciço de Garzón, localizado no setor sul da Cordilheira Oriental da Colômbia, a $300 \mathrm{~km}$ a Sul de Bogotá, forma um bloco alongado na direção NNE-SSW, com extensão aproximada de $10.000 \mathrm{~km}^{2}$. Estende-se desde a nascente do Rio Guayabero, a norte, até quase o Rio Caquetá, a sul. A área de estudo está situada no setor centro-sul do maciço e abrange os terrenos compreendidos entre o vilarejo do Recreo, a norte, a cidade de Florencia, a sul, o vilarejo de Puerto Rico, a leste, e Guadalupe a oeste (FIGURA 1).

O principal acesso à zona é a estrada que comunica a cidade de Garzón com Guadalupe e Florencia. A porção ocidental da área é alcançada por meio de estradas que ligam a cidade de Florencia com os vilarejos de Guayabal e Guadalupe. Ao nordeste da cidade de Florencia, na porção oriental da zona, o acesso é feito pela estrada que liga este centro urbano com os vilarejos de Montañita e El Doncello. 


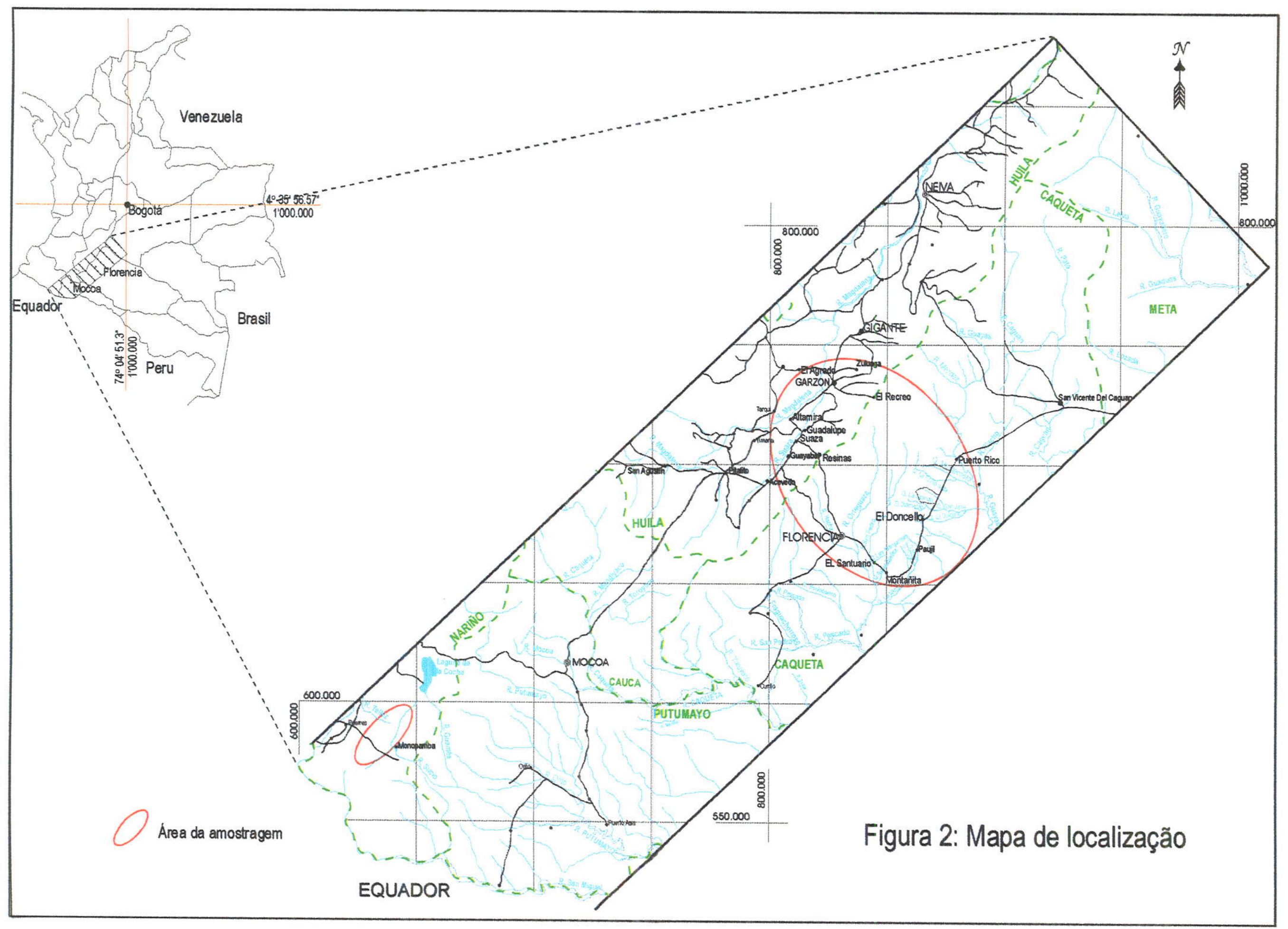




\section{GEOLOGIA}

Neste capítulo são compiladas as principais generalidades da geologia da Colômbia, bem como os estudos geológicos e geocronológicos já realizados no Maciço de Garzón. Alem disso, apresentam-se as características geológicas locais do Complexo Garzón.

\subsection{Geotectônica: generalidades e arcabouço}

Colômbia localiza-se no extremo noroeste da América do Sul e seu território divide-se em duas provincias geográficas: (i) Província Oriental (PO), que corresponde aos Llanos Orientais, e caracteriza-se por grandes planícies irrigadas por importantes rios, e, (ii) Provincia Ocidental (PW), conhecida como a região andina da Colômbia, onde emergem as cordilheiras Ocidental (CW), Central (CC) e Oriental (CO) (FIGURA 2).

Atualmente, a deformação intracontinental nos Andes da Colômbia resulta de uma complexa interação entre a placa da América do Sul com as placas oceânicas de Nazca e do Caribe (Kellog \& Vega apud TABOADA et al., 2000). O limite ao longo do qual acontece a atual transpressão nos Andes do Norte, no sentido NE, com relação à placa Sul-Americana, corresponde ao sistema de falhas de Algeciras, o qual conecta-se para NE com o sistema de falhas de Guaicaramo. Esta megaestructura transcorrente deslizante, com importante componente vertical que afeta tanto rochas de embasamento (Maciço de Garzón) como da cobertura sedimentar (VELANDIA et al., 2001), formou-se numa tectônica de convergência predominantemente oblíqua (FREYMUELLER et al., 1993).

As provincias geográficas, além de possuir uma marcante diferença fisiográfica, apresentam também características geológicas diferentes. Por isto os investigadores pioneiros, e recentemente Ordoñez (1997), propõem um modelo alóctone para explicar a configuração da região dentro da teoria de tectônica de placas. Neste modelo, para o Proterozóico tardio, a PO considera-se autóctone e parte integrante da Plataforma da América do Sul. Esta comporta-se como uma porção cratônica, tectonicamente estável, para os episódios tectono-magmáticos ocorridos no Fanerozóico dentro do cinturão andino (CORDANI \& SATO, 1999). Contrariamente, a PW (constituída por vários terrenos de origem diversa), considerada alóctone com respeito ao cráton, tem como característica principal o retrabalhamento do seu embasamento Proterozóico e a interação da margem continental da plataforma da América do Sul com uma serie de domínios de afinidade oceânica, acrescidos durante o Meso-Cenozóico.

A PO, cujas rochas cristalinas estão expostas a aproximadamente $300 \mathrm{~km}$ da frente de deformação dos Andes da Colômbia, é formada por rochas Proterozóicas, incluidas 


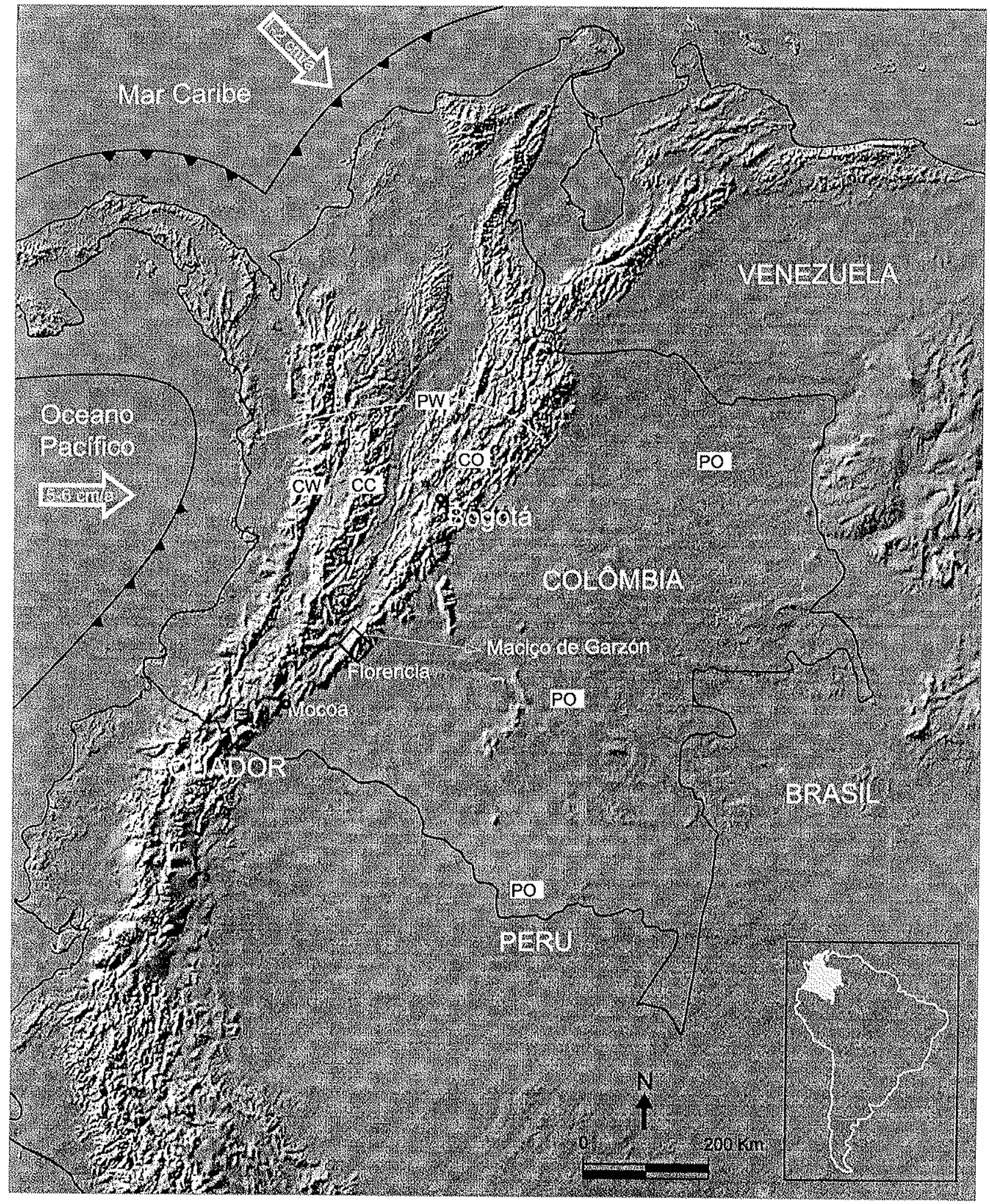

PO: Provincia Oriental; Província ocidental da Colômbia conformada por CC: Cordilheira Central, CO: Cordilheira Oriental, CW: Cordilheira Ocidental.

$\square$ Zona de amostragem

FIGURA 2. Províncias geográficas da Col ômbia 
temporalmente na província geocronológica Rio Negro-Juruena do Craton Amazônico (TASSINARI, 1996), com coberturas sedimentares proterozóicas a meso-cenozóicas Litologicamente as rochas do embasamento correspondem a uma associação de paragnaisses e migmatitos na fácies anfibolito superior, com granitóides associados de caráter sin e postectônico (GALVIS, 1979). PRIEM et al. (1989) identificaram: um evento tectono-magmático de 1560-1450 Ma que retrabalhou material mais antigo (de 1850 - 1750 Ma), e um evento termal entre 1350 e $1250 \mathrm{Ma}$, com base em datações Rb-Sr, U-Pb e K-Ar.

$\mathrm{Na}$ zona andina, a $\mathrm{CO}$ e o flanco Oriental da $\mathrm{CC}$ fazem parte do assim denominado terreno Chibcha, de origem continental, constituido por rochas ígneo-metamórficas pré-mesozóicas, as quais atingiram sua posição atual no Paleozóico Superior (RESTREPO \& TOUSSAINT, 1988). O embasamento está sobreposto por rochas sedimentares paleozóicas e por uma seqüência de rift mesozóica. Este embasamento pré-mesozóico está exposto desde o segmento sul oriental da cadeia Andina no Maciço de Garzón (Complexo Garzón), até as regiões mais setentrionais no Maciço de Santander (Gnaisse de Bucaramanga), Serra Nevada de Santa Marta (Granulito dos Mangos) e a Península da Guajira (Gnaisse de Jojoncito) (TSCHANZ et al., 1974; ALVAREZ, 1967; CARDONA, 2003). Esporadicamente aparece também, no flanco oriental da CC (Anfibolitos do Vapor, Anfibolitos de Tierradentro) (ORDOÑEZ, 1997; VESGA \& BARRERO, 1978), onde estos domínios aparecem segmentados. Numerosos corpos batolíticos e plutões graníticos jurássicos intrudem o embasamento. O magmatismo Jurássico está claramente identificado na região de Santander e Guajira, e afeta parcialmente o embasamento de Santa Marta (CARDONA, 2003). Os limites tectônicos do terreno Chibcha são falhas regionais que o limitam a leste com a $P O$, e a oeste com a região setentrional da CC (terreno Tahamí).

A região setentrional da CC (Terreno Tahami) constitui-se por complexos metamórficos prémesozóicos, cuja natureza e idade são ainda desconhecidas (TOUSSAINT, 1993), com coberturas de rochas sedimentares marinhas do Cretáceo Inferior e granitóides associados do Cretáceo Superior. Neste terreno foram identificados dois eventos tectono-magmáticos, um deles no Devoniano-Carbonifero (TOUSSAINT, 1993), e o outro no Triássico (ORDOÑEZ, 2001; VINASCO et al., 2001). O terreno Tahamí está limitado a leste com o Terreno Chibcha, e a oeste com terrenos de afinidade oceânica, por meio de importantes falhas regionais.

\subsection{Histórico dos trabalhos geológicos no Maciço de Garzón}

Diversos trabalhos foram realizados sobre a geologia do Maciço de Garzón, dos quais apresenta-se uma breve resenha, em ordem cronológico: 
GROSSE (1935) reporta pela primeira vez a existência de rochas metamórficas precambrianas a nordeste de Garzón e a leste-sudeste de Santa Librada, formando uma faixa estreita na borda oeste da Cordilheira Oriental. As rochas são anfibolitos e gnaisses anfibolíticos com intrusões de granitos e pegmatitos.

RADELLI (1962) descreve as feições petrográficas das rochas expostas na estrada AltamiraFlorencia e destaca seu caráter anatéctico numa expedição geológica realizada no Maciço de Garzón. As rochas do maciço, entre Guadalupe e Resinas, são descritas como augen gnaisses e epibolitos (migmatitos com porções graníticas concordantes), migmatitos heterogêneos e menores intercalações de granitos de anatexia. Entre Resinas e o Km 118 da rodovia são caracterizados augen gnaisses com alguns elementos melanocráticos, gradando a granitos de anatexia com textura xistosa ainda reconhecivel. Nesse setor desaparecem os anfibolitos, e aplitos-pegmatitos intrudem a seqüência sem direção preferencial. Estes últimos são considerados como produto das últimas etapas de anatexia, pelo fato de conterem os mesmos minerais dos granitos encaixantes.

KROONENBERG (1982) descreve a litologia e as paragêneses minerais das rochas precambrianas encontradas na região entre Algeciras e Acevedo (Huila) e as divide em: Grupo Garzón e Granitos de Guapotón e Mancagua. Este autor, além de discutir as prováveis condições de metamorfismo, apresenta também um modelo de colisão continental para explicar a origem dos granulitos da Faixa Garzón - Santa Marta. Neste modelo, os protolitos foram gerados num ambiente cálcio-alcalino do tipo arco andino a oeste do Craton Amazônico, e metamorfizados durante um evento orogênico próximo a $1.2-1.4 \mathrm{Ga}$, possivelmente relacionado com a orogenia de Grenville.

RODRIGUEZ (1985) diferenciou cartograficamente no Maciço de Garzón o granito de anatexia de El Recreo, a leste de Garzón. O autor interpreta esta rocha como o núcleo do maciço com transição de rochas bandadas para monzogranitos, feldspato alcalino granito, sienogranito e localmente granulitos charnockíticos. Alem disso, descreve a petrografia e microtexturas do Grupo Garzón e considera que algumas das pertitas e antipertitas têm origem metassomática, onde o k-feldspato (neossoma) infiltra-se no plagioclásio (paleossoma).

RESTREPO-PACE (1995) concorda com o caráter supracrustal das rochas do Maciço de Garzón, as quais incluem metavulcânicas e paragnaisses, bem como rochas plutônicas ricas em k-feldspato e cumulatos, com base em dados geoquímicos. O espectro das REE varía desde padrões planos a enriquecidos com LREE; as anomalias de Eu variam desde altamente 
negativas, para os gnaisses félsicos e paragnaisses, até a altamente positivas para os ortognaisses máficos.

INGEOMINAS \& GEOESTUDIOS LTDA, (2001 a,b) dividem informalmente o Grupo Garzón nos Granulitos do Vergel, Gnaisse das Margaritas, Gnaisse do Toro e Gnaisse do Recreo. As três primeiras unidades são definidas pela primeira vez, de acordo com o predomínio da litologia e sua extensão cartografável. O Gnaisse do Toro corresponde a hornblenda gnaisses de composição monzonítica a diorítica, e pode ter relação litológica com as rochas do Gnaisse de Guapotón-Mancagua.

KROONENBERG (2001) apresenta a geoquímica de elementos maiores e menores para os granulitos félsicos, intermediários, máficos e ultramáficos. Seus resultados indicam uma tendência cálcio-alcalina, com origem de rochas igneas em parte supracrustais. $\mathrm{Cr}$ e $\mathrm{Ni}$ tem sido fortemente enriquecidos nos granulitos ultramáficos e decrescem com o aumento da razão $\mathrm{FeO} / \mathrm{MgO}$. Os elementos compativeis ( $\mathrm{Sc}, \mathrm{V}, \mathrm{Co}$ ) decrescem com o aumento da diferenciação. Os granulitos máficos pertencem ao campo cálcio-alcalino o toleitico com baixo K. O comportamento das REE confirma os resultados de Restrepo-Pace (1995).

RODRIGUEZ, et al. (2002) realizam uma análise do trabalho de Ingeominas \& Geoestudios Ltda (2001 a,b) e incluem novas análises petrográficas. Propõem substituir o nome de Grupo Garzón por Complexo Garzón, e o subdividem com base no grau de conhecimento geológico das unidades propostas, em Migmatitos de Florencia e Granito-Granofels de Recreo. Os Migmatitos de Florencia agrupam os Granulitos do Vergel e o Gnaisse das Margaritas de INGEOMINAS \& GEOESTUDIOS Ltda. (2001 a,b).

\subsection{Dados geocronológicos existentes}

ALVAREZ \& CORDANI (1980); ALVAREZ (1981 a,b); ALVAREZ \& LINARES (1985) sugerem que as rochas precambrianas do embasamento do Maciço de Garzón, com idades em torno de $1100 \mathrm{Ma}$, expostas nos Andes da Colômbia, constituem remanescentes do cinturão metamórfico grenvilliano.

Com base nos dados geocronológicos surgem duas hipóteses: a primeira, de ALVAREZ (1981 a) e em parte apoiada por PRIEM et al. (1989), diz que pelo menos uma porção do embasamento do Maciço de Garzón correlaciona-se litológica e geocronologicamente com a parte adjacente do Craton de Guiana; a segunda trazida por KROONENBERG (1982), considera que a faixa granulítica Garzón-Santa Marta é diferente petrográfica e geocronologicamente da parte adjacente do Craton de Guiana, e formou-se na borda ocidental desse craton durante o evento orogênico de $\sim 1200-1400$ Ma. 
PRIEM et al. (1989) caracterizam dois eventos metamórficos com base em dados Rb-Sr rocha total e mineral, e K-Ar em micas. O primeiro, no Gnaisse de Guapotón-Mancagua, é sugerido por idades em torno de $1600 \mathrm{Ma}$ e se relaciona temporalmente com a parte adjacente do Escudo de Guiana. O segundo, evento metamórfico de alto grau, afeta o Grupo Garzón, com idade em torno de $1170 \mathrm{Ma}$ e resfriamento por volta de 975 e $915 \mathrm{Ma}$. O último evento é determinado por intrusão de veios pegmatíticos a $850 \mathrm{Ma}$.

RESTREPO-PACE (1995) \& RESTREPO-PACE et al. (1997) confirmam que as rochas do embasamento de Garzón foram metamorfoseadas durante o episódio tectonotermal regional de $\sim 1100 \mathrm{Ma}$, denominado de Orinoquiense na América do Sul, com base em dados U-Pb convencional, $\mathrm{Ar}-\mathrm{Ar}$ e $\mathrm{Sm}-\mathrm{Nd}$. As rochas formadas neste evento aparecem expostas esporadicamente ao longo dos Andes da Colômbia, e continuam no Peru, no Maciço de Arequipa, e no Sul do Craton Amazônico na Bolívia e no Brasil, até o nordeste da Precorditheira da Argentina.

Os dados geocronológicos citados acima foram compilados e estão apresentados no QUADRO 1.

\subsection{Correlações regionais prévias}

KROONENBERG (1982) considera o Maciço de Garzón como um fragmento do cinturão de alto grau que formou-se durante a aglutinação do Supercontinente de Rodinia. Devido a este fato, e pela sua posição estratégica nos Andes de Colômbia, os geólogos mexicanos estabelecem uma possivel conexão do maciço com o terreno Oaxaquia do México, com base nos dados isotópicos de Pb e U-Pb obtidos por RESTREPO-PACE (1995). Dados isotópicos de $\mathrm{Pb}$, obtidos por RUIZ et al. (1999), permitem fazer correlações dos maciços colombianos de Santa Marta e Garzón com os complexos mesoproterozóicos Oaxaca e Guichicovi (Terreno Oaxaquia) ao sul do México. Os autores sugerem que os blocos do embasamento de idade Grenville compartilham uma história comum para o Proterozóico tardio, e que foram parte de Gondwana durante o Paleozóico. Particularmente, as composições isotópicas de $\mathrm{Pb}$ do Maciço de Garzón são semelhantes às de Complexo Guichicovi, e além disso também são similares às das provincias Rio Negro Juruena e Rondônia-San Ignacio do Craton Amazônico.

A semelhança litológica, petrográfica, geocronológica e da trajetória P-T-t dos terrenos orogênicos de Oaxaquia do México, Adirondack Highlands da América do Norte, a parte interna do orógeno Grenville no Canadá, permite a KEPPIE \& ORTEGA-GUTIERREZ (1999) e KEPPIE et al. (2001) correlacioná-los entre si e com o Maciço de Garzón, ainda que, para este último, não houvessem dados da sua evolução P-T-t. Nesta correlação, os autores sugeriram 
QUADRO 1 - Geocronologia e geoquímica isotópica do Maciço de Garzón.

\begin{tabular}{|c|c|c|c|c|c|}
\hline Localização & Unidade & Litologia & Material e Método & $\begin{array}{c}\text { Idade em } \mathrm{Ma} \text {. } \\
\text { Características isotópicas }\end{array}$ & Autor \\
\hline $\begin{array}{l}\text { Estrada Florencia-Gua- } \\
\text { dalupe e San Antonio } \\
\end{array}$ & $\begin{array}{l}\text { Granulitos do } \\
\text { Vergel }\end{array}$ & $\begin{array}{l}\text { granulitos } \\
\text { charnockíticos, } n=4\end{array}$ & rocha total, Isócrona $\mathrm{Rb} / \mathrm{Sr}$ & $\begin{array}{l}1180 \pm 310 \mathrm{Ma} \\
\mathrm{RI}=0.704\end{array}$ & Alvarez (1981) \\
\hline $\begin{array}{l}\text { Estrada Florencia- } \\
\text { Guadalupe } \\
\end{array}$ & $\begin{array}{l}\text { Granulitos do } \\
\text { Vergel }\end{array}$ & granulito básico, $n=1$ & hornblenda, K/Ar mineral & $925 \pm 50$ & $\begin{array}{c}\text { Alvarez \& Linares } \\
(1985)\end{array}$ \\
\hline Rio Suaza & $\begin{array}{l}\text { Gnaisse de } \\
\text { Guapotón }\end{array}$ & augen gnaisse, $n=6$ & rocha total, Isócrona $\mathrm{Rb} / \mathrm{Sr}$ & $\begin{array}{l}1596 \pm 300 \\
R I=0.702 \pm 0.005\end{array}$ & \multirow{12}{*}{ Priem et al . (1989) } \\
\hline $\begin{array}{l}\text { Córrego Aguacaliente e } \\
\text { Rio suaza } \\
\end{array}$ & $\begin{array}{l}\text { Granulitos do } \\
\text { Vergel } \\
\end{array}$ & $\begin{array}{l}\text { gnaisses, } n=3+5 \\
\text { Alvarez, (1981) }\end{array}$ & rocha total, Isócrona $\mathrm{Rb} / \mathrm{Sr}$ & $\begin{array}{l}1172 \pm 90 \\
R I=0.704 \pm 0.002\end{array}$ & \\
\hline Rio Suaza & $\begin{array}{l}\text { Granulitos do } \\
\text { Vergel } \\
\end{array}$ & $\begin{array}{l}\text { granitoide pegma- } \\
\text { títico, } n=2\end{array}$ & rocha total, Isócrona $\mathrm{Rb} / \mathrm{Sr}$ & $847, \mathrm{RI}=0.709$ & \\
\hline Rio Suaza & $\begin{array}{l}\text { Granulitos do } \\
\text { Vergel } \\
\end{array}$ & $\begin{array}{l}\text { granitoide pegma- } \\
\text { títico, } n=1\end{array}$ & $\begin{array}{l}\text { k-feldspato, Isócrona con- } \\
\text { vencional } \mathrm{Rb} / \mathrm{Sr}\end{array}$ & $\begin{array}{l}895 \pm 16 \\
\text { (convencional) }\end{array}$ & \\
\hline Córrego Aguacaliente & $\begin{array}{l}\text { Granulitos do } \\
\text { Vergel }\end{array}$ & anfibolito-cpx, $n=1$ & hornblenda, KAr mineral & $971 \pm 19$ & \\
\hline Rio Suaza & $\begin{array}{l}\text { Granulitos do } \\
\text { Vergel } \\
\end{array}$ & anfibolito, $n=1$ & hornblenda, K/Ar mineral & $955 \pm 19$ & \\
\hline Rio Suaza & $\begin{array}{l}\text { Granulitos do } \\
\text { Vergel }\end{array}$ & anfibolito, $n=1$ & hornblenda, KIAr mineral & $1000 \pm 25$ & \\
\hline \multirow[t]{2}{*}{ Córrego Aguacaliente } & Granulitos do & \multirow[t]{2}{*}{ mármore, $n=1$} & $\begin{array}{l}\text { rocha total e mineral, Isócrona } \\
\mathrm{Rb} / \mathrm{Sr}\end{array}$ & $918 \pm 27$ & \\
\hline & Vergel & & flogopita, K/Ar mineral & $912 \pm 35$ & \\
\hline \multirow[t]{2}{*}{ Rio Suaza } & Gnaisse de & \multirow[t]{2}{*}{ augen gnaisse, $n=1$} & rocha total e mineral, Isócrona $\mathrm{Rb} / \mathrm{Sr}$ & $390 \pm 19$ & \\
\hline & Guapotón & & biotita, K/Ar mineral & $216 \pm 5$ & \\
\hline Rio Paez & embasamento* & $\begin{array}{l}\text { gnaisse } \\
\text { trondhjemítico, } n=1\end{array}$ & $\begin{array}{l}\text { rocha total e mineral, Isócrona } \\
\mathrm{Rb} / \mathrm{Sr}\end{array}$ & $136 \pm 4$ & \\
\hline
\end{tabular}

** Precambriano do ocidente da Corditheira Central da Colombia 
QUADRO 1 - Geocronologia e geoquímica isotópica de rochas do Maciço de Garzón.

\begin{tabular}{|c|c|c|c|c|c|}
\hline Localização & Unidade & Litologia & Material e Método & $\begin{array}{c}\text { Idade em Ma. } \\
\text { Características isotópicas }\end{array}$ & Autor \\
\hline Não indicada & \begin{tabular}{|l} 
Gnaisse de \\
Guapotón
\end{tabular} & augen gnaisse, $n=1$ & $\begin{array}{l}6 \text { zircões, U/Pb convencional e } \\
\text { Sm/Nd }\end{array}$ & $\begin{array}{l}1088 \pm 6 \\
\text { (concordia-2 zrn) }\end{array}$ & \multirow{8}{*}{$\begin{array}{c}\text { Restrepo-Pace } \\
\text { (1995) }\end{array}$} \\
\hline $\begin{array}{l}\text { Estrada Florencia- } \\
\text { Guadalupe }\end{array}$ & $\begin{array}{l}\text { Gnaisse de } \\
\text { Guapotón }\end{array}$ & augen gnaisse, $n=1$ & $\begin{array}{l}\text { hornblenda, Ar/Ar steps } \\
\text { rocha total, Nd }\end{array}$ & $\begin{array}{ll}890 \text { máxima } & T_{D M}=1500 \\
180 \text { mínima } & \epsilon_{\mathrm{Nd}}=-0.7_{(1100)}\end{array}$ & \\
\hline Córrego El Higado & embasamento ${ }^{\star \star}$ & $\begin{array}{l}\text { anfibolito gná issico, } \\
n=1\end{array}$ & $\begin{array}{l}\text { hornblenda e rocha total, } \mathrm{Ar} / \mathrm{Ar} \\
\text { steps e } \mathrm{Sm} / \mathrm{Nd}\end{array}$ & $\begin{array}{l}T_{D M}=1970 \\
\epsilon_{N d}=+0.2(1100)\end{array}$ & \\
\hline $\begin{array}{l}\text { Estrada Florencia- } \\
\text { Guadalupe }\end{array}$ & \begin{tabular}{|l} 
Granulitos do \\
Vergel
\end{tabular} & hornblendito op $x, n=1$ & $\begin{array}{l}\text { hornblenda, Ar/Ar steps } \\
\text { espectro Ar excesso }\end{array}$ & 1074 & \\
\hline $\begin{array}{l}\text { Estrada Florencia- } \\
\text { Guadalupe }\end{array}$ & $\begin{array}{l}\text { Granulitos do } \\
\text { Vergel }\end{array}$ & & rocha total, Sm/Nd & $\begin{array}{l}T_{D M}=1460 \\
\epsilon_{\mathrm{Nd}}=+0.91_{\{100\}}\end{array}$ & \\
\hline $\begin{array}{l}\text { Estrada Florencia- } \\
\text { Guadalupe }\end{array}$ & $\begin{array}{l}\text { Granulitos do } \\
\text { Vergel }\end{array}$ & $\begin{array}{l}\text { gnaisse } \\
\text { charnockítico, } n=1\end{array}$ & rocha total, Sm/Nd & $\begin{array}{l}T_{D M}=1460 \\
\varepsilon_{\mathrm{Nd}}=+0.92_{(1100)}\end{array}$ & \\
\hline Não indicada & $\begin{array}{l}\text { Granulitos do } \\
\text { Vergel } \\
\end{array}$ & & rocha total, $\mathrm{Sm} / \mathrm{Nd}$ & $\begin{array}{l}T_{D M}=1460 \\
\epsilon_{N d}=+0.93_{(100)}\end{array}$ & \\
\hline $\begin{array}{l}\text { Estrada Florencia- } \\
\text { Guadalupe }\end{array}$ & $\begin{array}{l}\text { Granulitos do } \\
\text { Vergel }\end{array}$ & anfibolito, $n=1$ & rocha total, $\mathrm{Sm} / \mathrm{Nd}$ & $\begin{array}{l}T_{D M}=1460 \\
\epsilon_{N d}=+0.94_{(1100)}\end{array}$ & \\
\hline Não indicada & $\begin{array}{l}\text { Gn.Guapotón e } \\
\text { G. Vergel } \\
\end{array}$ & $\begin{array}{l}\text { augen } \text { gn, gnaisse } \\
\begin{array}{l}\text { m. e f., granulitos } \\
n=11\end{array}\end{array}$ & rocha total, $\mathrm{Pb} / \mathrm{Pb}$ & $\begin{array}{l}{ }^{206} \mathrm{~Pb}{ }^{204} \mathrm{~Pb}=17.8-24.4 \\
{ }^{207} \mathrm{~Pb}{ }^{204} \mathrm{~Pb}=15.5-16.1 \\
{ }^{208} \mathrm{~Pb}{ }^{204} \mathrm{~Pb}=36.8-41.1\end{array}$ & Ruiz et al . (1999) \\
\hline $\begin{array}{l}\text { Estrada Florencia- } \\
\text { Guadalupe }\end{array}$ & \begin{tabular}{|l}
$\begin{array}{l}\text { Granulitos do } \\
\text { Vergel }\end{array}$ \\
\end{tabular} & $n=1$ & hornblenda, K/Ar mineral & $902 \pm 20$ & $\begin{array}{l}\text { Van der Wiel } \\
\text { (1991) }\end{array}$ \\
\hline
\end{tabular}

$n=$ No. de amostras

* Maciço da Plata

** Precambriano do ocidente da Cordihheira Central da Colômbia 
que os mesmos terrenos foram partes de arcos vulcânicos, formados no Oceano Grenville entre Laurêntia, Báltica e Amazônia, os quais foram circundados pelas maiores massas continentais. De acordo com os dados existentes para Oaxaquia, este terreno estaria situado na margem noroeste da Amazônia a $990 \mathrm{Ma}$, de modo que KEPPIE et al. (2001) sugeriram que o metamorfismo na fácies granulito de Oaxaquia não teria sido gerado pela colisão continente-continente, mas pela colisão do arco de Oaxaquia com o Craton Amazônico.

\subsection{Geologia local}

O Maciço de Garzón forma um bloco tectônico alongado na direção NE, o qual está cortado por falhas de empurrão concomitantes com o levantamento da Cordilheira Oriental da Colômbia, e resultantes da deformação compressional na borda noroeste da América do Sul (DENGO \& COVEY, 1993). Encontra-se limitado a oeste pela falha de Altamira do sistema de Falhas de Algeciras, que serve de contato tectônico com rochas sedimentares do Vale Superior do Magdalena. Entretanto, a leste, embora algumas falhas menores o coloquem em contato com rochas sedimentares cretáceas ou sedimentos terciarios das bacias de Caquetá e Putumayo, seu limite não está determinado por uma megaestrutura. Uma possível prolongação para nordeste deste maciço são as rochas metamórficas da Serrania da Macarena, consideradas proterozóicas pelas suas relações estratigráficas.

Uma seqüência sedimentar cambro-ordovícica de $1.500 \mathrm{~m}$ de espessura, com trilobitas Ehmania e Paraxides, sobrepöe-se discordantemente às rochas do Maciço de Garzón na Serrania da Macarena (BRIDGER, 1982). No extremo sudeste, o embasamento está coberto por rochas vulcano-sedimentares jurássicas da Formação Saldaña. Associado a este magmatismo têm-se os equivalentes plutônicos cálcio-alcalinos do Batólito de Mocoa, com desenvolvimento de importantes jazidas minerais. O magmatismo tardio estende-se ao norte do maciço, ao longo da Falha de Altamira, onde stocks graníticos pós-orogénicos do Granito de Altamira intrudem as rochas metamórficas.

VAN DER WIEL (1991) obteve taxas do levantamento e erosão por médio de traços de fissão em apatitas, em amostras da porção oeste do maciço e da adjacente bacia de Neiva. No tempo transcorrido entre $12 \mathrm{Ma}$ até o presente, o maciço foi soerguido $6.5 \mathrm{~km}$ em pelo menos dois pulsos. O episódio mais antigo ocorreu a $\sim 12 \mathrm{Ma}$ e se caracterizou por um rápido levantamento, e o mais jovem começou a 6.4 Ma e terminou possivelmente há 3.3 Ma.

Compila-se no QUADRO 2 a nomenclatura estratigráfica do Maciço de Garzón segundo vários autores. Para a área amostrada nesta pesquisa, adota-se a denominação de Rodriguez et al. (2002) de Gnaisse de Guapotón-Mancagua e Complexo Garzón. Porem este último foi 
subdividido informalmente nos Granulitos do Vergel e Gnaisse das Margaritas, como aparece nas cartas geológicas em escala 1:100.000, que servem de base para o desenvolvimento desta pesquisa. Esta calcificação baseia-se no predominio de uma determinada litologia e sua extensão cartografável, conforme INGEOMINAS \& GEOESTUDIOS Ltda. (2001 a,b).

As folhas empregadas $(367,368,389,390,414,448)$ foram elaboradas pelo Instituto de Investigación e Información Geocientifica, Minero-Ambiental y Nuclear (INGEOMINAS) e seguem a nomenclatura do IGAC. A resultante carta está compilada no ANEXO I. Com base nesta cartografia revisaram-se duas seções geológicas, uma na folha 389 , na estrada Florencia - Guayabal, e a outra na folha 414, no córrego das Margaritas, onde as boas exposições das rochas permitiram um melhor detalhe geológico e petrológico para este setor.

\section{QUADRO 2. NOMENCLATURA ESTRATIGRÁFICA DO MACIÇO DE GARZÓN}

\begin{tabular}{|c|c|c|c|c|c|c|c|c|c|}
\hline Autor & $\begin{array}{l}\text { Grosse } \\
(1935)\end{array}$ & $\begin{array}{l}\text { Radelli } \\
(1962) \\
\end{array}$ & $\begin{array}{c}\text { Kroonenberg } \\
(1982)\end{array}$ & $\begin{array}{c}\text { Van der Wiel } \\
\text { (1991) }\end{array}$ & $\begin{array}{c}\text { Rodriguez } \\
\text { (1985) }\end{array}$ & \multicolumn{2}{|c|}{$\begin{array}{c}\text { Ingeominas \& } \\
\text { Geoestudios } \\
(2001 \mathrm{a} . \mathrm{b})\end{array}$} & \multicolumn{2}{|c|}{ Rodriguez et al. (2002) } \\
\hline \multirow{3}{*}{$\begin{array}{l}\text { Nomen- } \\
\text { clatura }\end{array}$} & \multirow{3}{*}{$\begin{array}{l}\text { anfibolitos } \\
\text { gnaisses } \\
\text { e granitos }\end{array}$} & $\begin{array}{l}\text { Augen } \\
\text { gnaisses }\end{array}$ & $\begin{array}{lr}\text { Granitos } & \text { de } \\
\text { Guapotón } & \mathrm{e} \\
\text { Mancagua } & \end{array}$ & $\begin{array}{l}\text { Gnaisse } \\
\text { augen } \\
\text { Mancagua e } \\
\text { Guapoton }\end{array}$ & $\begin{array}{l}\text { Gnaisse de } \\
\text { Mancagua e } \\
\text { Guapotón }\end{array}$ & Gnaisse & de Guapotón & $\begin{array}{l}\text { Gnaisse d } \\
\text { Mancagua }\end{array}$ & e Guapotón- \\
\hline & & \multirow{2}{*}{$\begin{array}{l}\text { epibolitos, } \\
\text { migmatitos, } \\
\text { granitos de } \\
\text { anatexia }_{s} \\
\text { pegmatitos }\end{array}$} & \multirow[b]{2}{*}{ Grupo Garzón } & \multirow[b]{2}{*}{$\begin{array}{l}\text { Grupo } \\
\text { Garzón }\end{array}$} & $\mid \begin{array}{ll}\text { Granito } & \text { de } \\
\text { anatexia } & \text { do } \\
\text { Recreo } & \end{array}$ & \multirow[b]{2}{*}{$\begin{array}{l}\text { Grupo } \\
\text { Garzón }\end{array}$} & $\begin{array}{l}\text { do Toro } \\
\text { Gnaisse do } \\
\text { Recreo }\end{array}$ & \multirow[b]{2}{*}{$\begin{array}{l}\text { Complexo } \\
\text { Garzón }\end{array}$} & $\begin{array}{l}\text { Granito- } \\
\text { Granofels } \\
\text { do Recreo }\end{array}$ \\
\hline & & & & & $\begin{array}{l}\text { Grupo } \\
\text { Garzón }\end{array}$ & & \begin{tabular}{|l|}
$\begin{array}{l}\text { Granulitos do } \\
\text { Vergel }\end{array}$ \\
$\begin{array}{l}\text { Gnaisse das } \\
\text { Margaritas }\end{array}$ \\
\end{tabular} & & $\begin{array}{l}\text { Migmatitos } \\
\text { de } \\
\text { Florencia }\end{array}$ \\
\hline
\end{tabular}

\subsubsection{Gnaisse de Guapotón-Mancagua}

Esta unidade é formada por duas faixas de gnaisses, localizadas ao longo do Vale do Rio Suaza, uma ao norte de Guadalupe, e outra ao norte de Guayabal. Além destas, outra faixa localiza-se perto dos córregos de Santa Helena e das Doradas.

Constitui-se de quartzo-feldspato ortognaisses, cinza claro esverdeado e rosa, com megacristais augen de k-feldspato e quartzo (PRANCHA 1 - Foto 1) que atingem dimensões entre 1 $3 \mathrm{~cm}$ (KROONENBERG, 1982). Em nivel de afloramento estas rochas näo têm bandamento composicional nem evidências de processos migmatíticos; ao contrário, os minerais máficos estão concentrados em agregados glomeroporfiriticos (INGEOMINAS \& GEOESTUDIOS, 2001 a). O contato desta unidade com os Granulitos do Vergel é concordante e localmente falhado. 
Perto do vilarejo de Guayabal, o gnaisse granitico, intensamente alterado, é atravessado por diques anfibolíticos, dioríticos e graníticos-pegmatíticos, com magnetita e biotita de até $5 \mathrm{~cm}$ de comprimento.

Pelo fato desta unidade ser extensa e de composição homogênea, considera-se a sua provável origem magmática.

\subsubsection{Complexo Garzón}

Corresponde a uma seqüência metamórfica bandada de rochas de alto grau de metamorfismo (fácies granulito e anfibolito), que ocupa a maior extensão do Maciço de Garzón. Sua composição predominante é quartzo-feldspática, com intercalações pelíticas, máficas, ultramáficas e calcio-silicáticas, cortada por diques de granito pegmatítico e lamprófiros (KROONENBERG, 1982).

As rochas quartzo-feldspáticas consistem de granulitos charnockiticos a enderbíticos e gnaisses, nos quais intercalam-se bandas decimétricas de anfibolitos. Os gnaisses pelíticos estão intercalados nos granulitos em varias localidades como em San Antonio, córrego Aguacaliente, bacia do Rio Neiva e córrego das Margaritas. As rochas calcio-silicáticas e ultramáficas são mais restritas e afloram na porção ocidental do maciço e as calcio-silicáticas localizam-se no córrego Aguacaliente ao sudeste da Jagua (KROONENBERG, 1982). mesmo autor observou, em seixos roeados do Rio Neiva, coroas de reação de cordierita, ortopiroxênio, magnetita e ás vezes espinélio verde ao redor de granada e quartzo, indicando metamorfismo de contato sobreposto aos granulitos já formados.

De modo geral observou-se uma mudança no grau metamórfico de oeste para o leste. A oeste, quartzo-feldspato gnaisses e gnaisses charnockíticos atingiram o fácies granulito; na porção média, os gnaisses possuem minerais típicos do facies anfibolito e granulito (zona de transição). A leste encontram-se somente gnaisses com paragênese representativa do facies anfibolito (QUADRO 3). Relações semelhantes foram descritas por COLLERSON (1976) para rochas metamórficas de alto grau da Austrália central.

$\mathrm{Na}$ porção mais a leste, as rochas sofreram retrometamorfismo na fácies xisto verde, com desenvolvimento de clorita (a partir de biotita e granada), arfvedsonita (a partir de hornblenda), actinolita (a partir de clinopiroxênio) e moscovita.

A transição no grau metamórfico (anfibolito a granulito) é de particular importância pois as condições de pressão e temperatura prevalescentes coincidem com as condições para gerar 
QUADRO 3. FACIES EPARAGÊNESES METAMÓRFICAS DAS ROCHAS DO COMPLEXO GARZÓN

\begin{tabular}{|l|l|}
\hline FACIES METAMÓRFICA & \multicolumn{1}{|c|}{ PARAGÊNESES } \\
\hline Granulito & $\begin{array}{l}\text { quartzo + plagioclásio + ortopiroxênio + k-feldspato mesopertítico + } \\
\text { biotita } \pm \text { hornblenda }\end{array}$ \\
\hline $\begin{array}{l}\text { Transição granulito- } \\
\text { anfibolito }\end{array}$ & $\begin{array}{l}\text { quartzo + plagioclásio + ortopiroxênio } \pm k \text {-feldspato } \pm \text { granada } \pm \\
\text { biotita e plagioclásio com microclínio antipertítico; ou quartzo + } \\
\text { plagioclásio + microclínio + biotita } \pm \text { granada } \pm \text { sillimanita e k- } \\
\text { feldspato com plagioclásio mesopertítico }\end{array}$ \\
\hline Anfibolito & $\begin{array}{l}\text { biotita + granada + microclínio (com geminação em grade } \\
\text { proeminente) } \pm \text { sillimanita }\end{array}$ \\
\hline
\end{tabular}

fusão parcial (anatexia) e formação de migmatitos. As texturas migmatíticas são comuns e encontram-se desde a estromática, onde bandas centimétricas a métricas de leucossoma e mesossoma alternam-se monotonamente, até texturas dobrada, ptigmática, agmatítica e boudinada com arranjos mais complexos que envolvem paleossoma, melanossoma, leucossoma e pegmatitos.

\subsubsection{Granulitos do Vergel}

As melhores exposições dessa unidade estão no perfil aflorante na estrada que liga Guayabal com Florencia. Correspondem principalmente a uma seqüência bandada de alto grau de bandas félsicas (aproximadamente $80 \%$ ) e máficas cujos contatos são muito claros (PRANCHA 1 - Foto 2). Em alguns lugares encontram-se niveis onde os componentes máficos e félsicos estão misturados. Esta seqüência está cortada por lentes e diques pegmatíticos quartzo-feldspáticos de espessura variável, com texturas mirmequítica, gráfica e pertítica, e ocasionalmente, por lamprófiros de até $1 \mathrm{~m}$ de espessura.

As bandas félsicas consistem principalmente de charnockito gnaisses (granulitos) e quartzofeldspato gnaisses, bandados centimétrica a decimetricamente, e com porções menores de granito e quartzo-sienito gnaisses de possivel origem anatéctica. Paralelamente ao bandamento e à foliação, intercalam-se bandas máficas de até $5 \mathrm{~m}$ de espessura, constituídas por hornblenda-piroxênio granulito e anfibolito. Esporádicos niveis de granulito ultramáfico estão presentes.

Os granulitos são granoblásticos, de granulação média a grossa, de verde cinzento a negro esverdeado, dando à rocha uma falsa aparência de rocha máfica. Consistem de plagioclásio, piroxênio, k-feldspato, quartzo, biotita marrom, hornblenda, granada e em menor quantidade ilmenita. A composição mineralógica do granulito varia localmente pelo conteúdo dos minerais máficos e félsicos, encontrando-se setores em que a rocha é biotita e/ou piroxênio granulito 
pela concentração destes minerais, dispostos em lâminas centimétricas.

Os gnaisses têm foliação marcada por minerais máficos. São granoblásticos, de granulação fina a grossa e localmente faneriticos, rosa e cinza claro, e consistem principalmente de $k$ feldspato, plagioclásio e quartzo em proporções variáveis, e em menor quantidade de clinopiroxênio, hornblenda, biotita e granada.

\subsubsection{Gnaisse das Margaritas}

As melhores exposições dessa unidade encontram-se no córrego das Margaritas, localizado $20 \mathrm{~km}$ a leste de Florencia. A nivel de afloramento a rocha corresponde a um migmatito com alternância de bandas estromáticas de mesossomas (60\%) e leucossomas (35\%) centimétricas, com menores intercalações de pacotes de anfibolitos (5\%). Localmente, pela mistura das bandas claras e escuras, é difícil a distinção entre mesossoma e leucossoma, resultando um gnaisse cinza claro com menores remanescentes das porções mais claras. Toda a seqüência está cortada por diques pegmatiticos que atravessam a rocha em diferentes direções, com espessuras desde centimétricas até métricas (PRANCHA 1 - Foto 3 ).

Em escala de afloramento, apresentam estrutura estromática em $80 \%$ dos casos. Estruturas em dobras que afetam o leucossoma e mesossoma; agmatítica e ptigmática nos leucosomas rosa, e boudinada nos anfibolitos (PRANCHA 1 - Foto 3 ) constituem os $20 \%$ restantes. Pela presença de dobras e boudins pode-se concluir que uma fase de deformação dúctil afetou toda a seqüência migmatítica.

Os mesossomas consistem principalmente de gnaisses granoblásticos cinza constituídos por quartzo - plagioclásio - microclínio - biotita, às vezes com granada, e de gnaisses lepidoblásticos biotíticos escuros com sillimanita. Esta associação sugere protolitos psamíticos (grauváquicos), que se alternam com niveis menores pelíticos. Outro tipo de mesossoma mais restrito, em esporádicas intercalações na seqüência, corresponde a anfibolitos granoblásticos cinza escuro constituídos de hornblenda, plagioclásio e biotita; particularmente estes níveis não foram afetados pela migmatização.

Distinguem-se três tipos diferentes de leucossomas em relação a composição, posição estrutural e gênese:

(1) quartzo-feldspato gnaisses brancos, associados aos biotita-gnaisses, que correspondem a segregações leucossomaticas concentradas, em laminas milimétricas ou em bolsões (PRANCHA 1 - Fotos 4,5). Estes leucossomas, cristalizados in situ, de grão fina a média, 
consistem principalmente de quartzo, k-feldspato e granada, e foram formados por fusão parcial dos biotita-gnaisses, dando lugar a metatexitos onde o mesossoma restítico alterna-se com o leucossoma.

Provavelmente, este leucossoma migmatítico formou-se por fusão parcial em condições anidras (fundido silicático insaturado em água), onde a biotita foi uma fase importante na sua produção. A presença de uma fase incongruente como granada concentrada nos leucosomas (PRANCHA 1 - Fotos 4 e 5) aponta para uma fusão insaturada de água (KRIEGSMAN, 2001).

(2) granito-gnaisses rosa de grão fina a muito grossa, constituídos por microclínio, plagioclásio, quartzo, biotita e localmente granada. Estes leucossomas dão origem a bandas graníticas desde milimétricas a centimetricas que injetam os gnaisses cinza (PRANCHA 1 - Foto 6). Possivelmente correspondem aos produtos de fundidos graníticos remobilizados, pois aparecem freqüentemente preenchendo lugares de dilatação das rochas deformadas em estado plástico (PRANCHA 1 - Foto 7).

(3) leucossomas pegmatíticos rosa consistentes de k-feldspato, plagioclásio, quartzo, e biotita com até $10 \mathrm{~cm}$ de comprimento (PRANCHA 1 - Foto 3,8). Estes granitos pegmatíticos podem refletir a cristalização final de um fundido granítico rico em água, formado quando o sistema atravessa o solidus saturado em água a pressões mais baixas (THOMPSON, 2001).

Nos Gnaisses das Margaritas desenvolve-se uma foliação $\left(S_{1}\right)$ N50 $E / 80 S E$, e localmente uma foliação milonítica sobreposta $\left(S_{2}\right), N 5^{\circ} E / 34^{\circ} \mathrm{W}$, possivelmente associada com 0 crescimento de biotita e sillimanita nos gnaisses (PRANCHA 2 - Foto 6), e de biotita e plagioclásio nos granulitos (PRANCHA 3 - Fotos 7 e 8). Posterior ao cisalhamento em condições de alto strain dúctil desenvolveu-se uma tectônica rúptil de falhamentos que deslocam os pegmatitos, estes interpretados como as últimas fases geradas no metamorfismo de alto grau (PRANCHA 1 - Foto 3). Estas falhas podem estar associadas ao Falhamento do Rio San Pedro que corresponde ao empurrão mais oriental responsável pelo soerguimento do maciço durante a tectônica transcorrente andina. 


\section{PRANCHA 1}

FOTO 1. Gnaisse quartzo-feldspato com homblenda e biotita. Observam-se os cristais augen de k-feldspato e quartzo (INGEOMINAS \& GEOESTUDIOS, 2001).

FOTO 2. Granulitos com bandas félsicas e máficas (INGEOMINAS \& GEOESTUDIOS, 2001).

FOTO 3. Sequêencia migmatítica constituída por intercalações de quartzo-plagioclásio-biotita gnaisses cinza (mesossoma) e granito gnaisses rosa pálido (leucossoma 2). O mesossoma esta assimilado pelo leucossoma 2. Boudins de anfibolitos cinza escuros intercalam-se nos migmatitos. O granito pegmatito rosa (leucossoma 3) corta o migmatito e está destocado por uma falha dextral.

FOTO 4 Metatexito constituído por biotita gnaisses escuros e quartzo-plagioclásio gnaisses com granada (leucossoma 1). O leucossoma 2 injeta o metatexito.

FOTO 5. Bolsões de quartzo-plagioclásio gnaisse (leucossoma 1) em biotita gnaisse escuro. A granada está concentrada nas segregações leucocráticas.

FOTO 6. Detalhe do quartzo-feldspato gnaisse cinza injetado pelo granito gnaisse rosa pálido (leucossoma 2).

FOTO 7. Migmatito dobrado constituído por intercalações estromáticas de quartzo-feldspatobiotita gnaisses cinza e quartzo-feldspato gnaisses rosa. Outra geração de gnaisses rosa preenchem o eixo da dobra e desenvolvem estrutura ptigmática.

FOTO 8. Detalhe do pegmatito com biotita de até $10 \mathrm{~cm}$ de comprimento (leucossoma 3 ). 

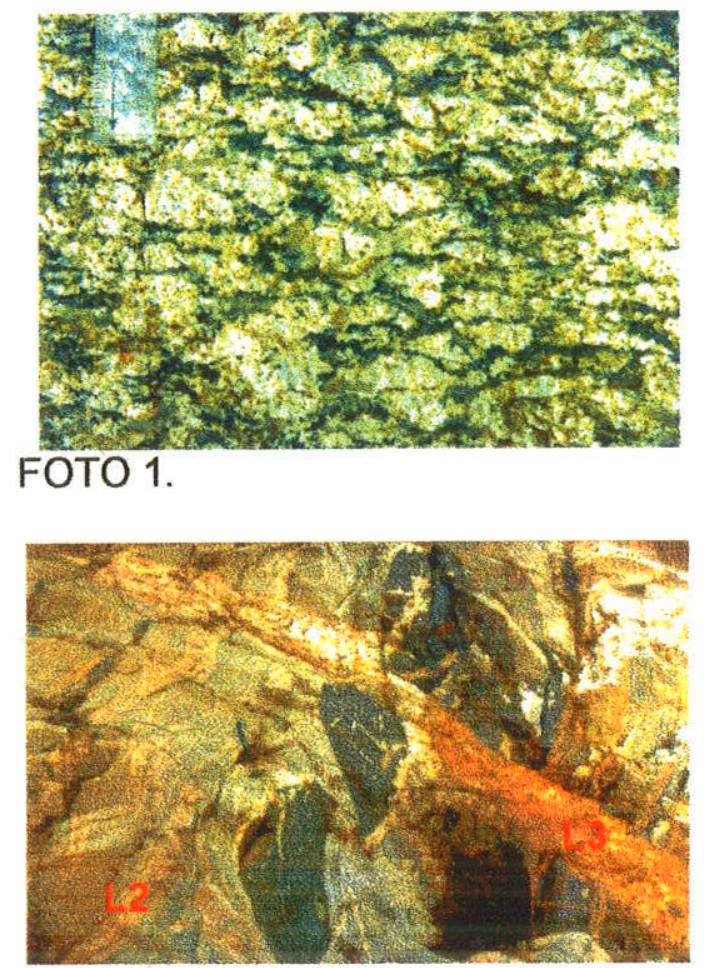

FOTO 3.
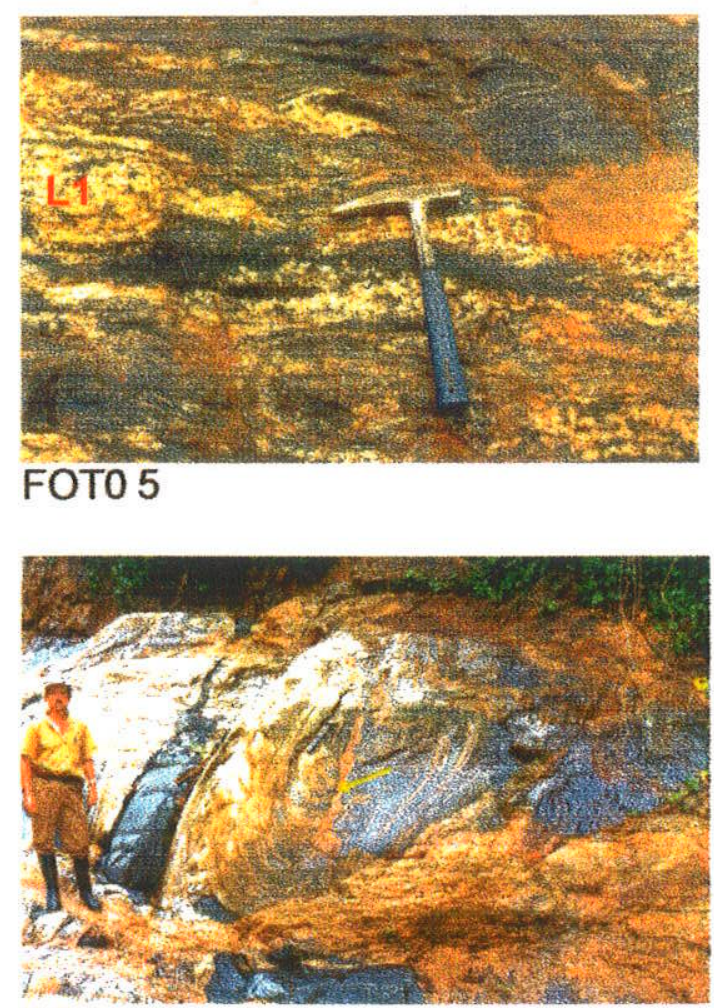

FOTO 7.

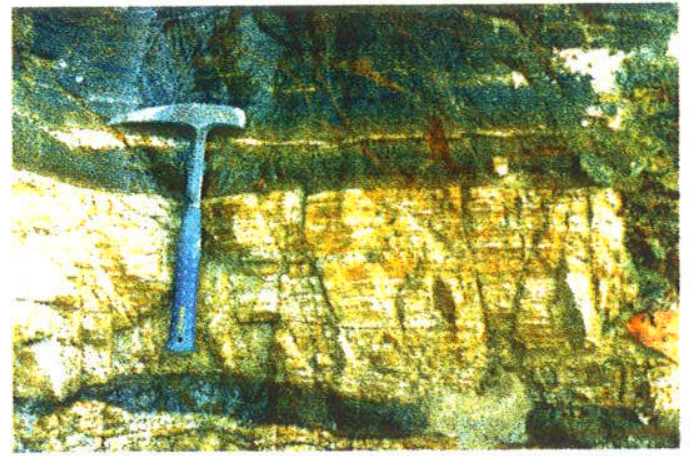

FOTO 2

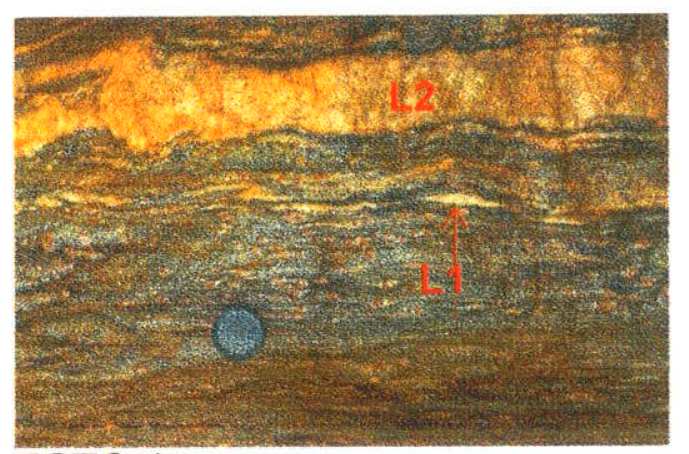

FOTO 4.

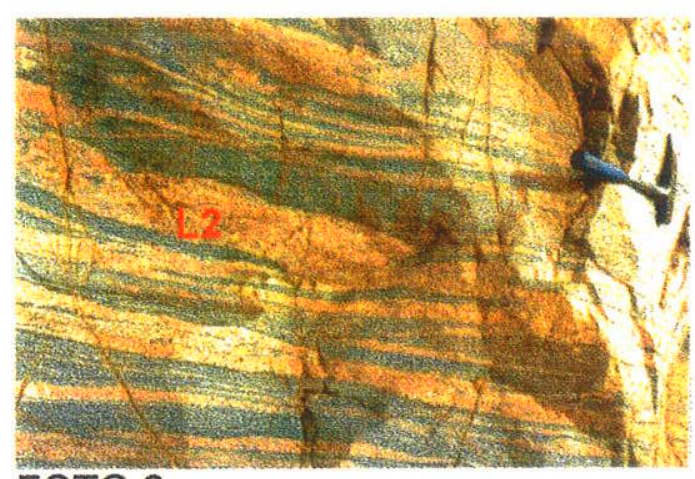

FOTO 6.

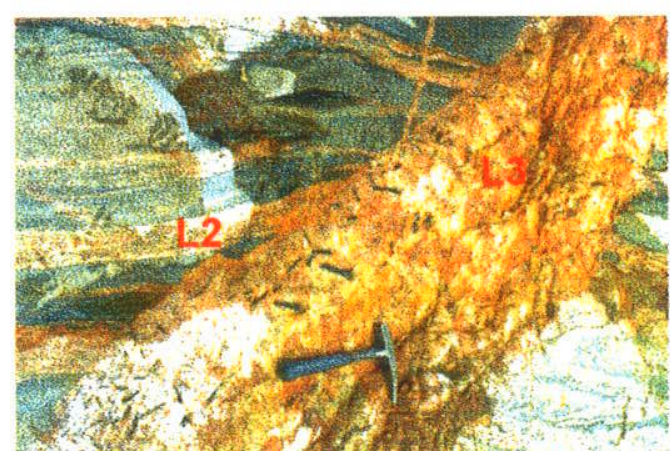
FOTO 8. 


\section{PETROLOGIA E ASPECTOS DO METAMORFISMO}

O estudo petrológico das unidades do Maciço de Garzón tem como objetivo fundamental conhecer as principais paragêneses, reações e condições do metamorfismo. Por meio desta ferramenta, ainda que as feições iniciais das rochas sejam pouco preservadas durante o metamorfismo de alto grau, pretende-se determinar os seus protolitos.

As rochas do maciço foram metamorfoseadas nas fácies anfibolito superior e granulito. Apesar de que a fácies granulito predomina na porção oeste e a fácies anfibolito na borda leste do maciço, existem intercalações de gnaisses e anfibolitos nos granulitos. Isto ocorre possivelmente devido à alternância de leitos com diferentes composições químicas mineralógicas.

Foram estudadas 23 lâminas delgadas neste trabalho e foram revisadas as descrições petrográficas de 28 lâminas delgadas de ANNICCHIARICO (2000) e 20 de GOMEZ (2002) para as diversas unidades do maciço. No total, 38 lâminas pertencem aos Granulitos do Vergel, 25 lâminas ao Gnaisse das Margaritas, e 8 lâminas ao Gnaisse de GuapotónMancagua.

\subsection{Gnaisse de Guapotón-Mancagua}

Correspondem a hornblenda - biotita e hornblenda - piroxênio gnaisses de composição granítica e gabro-norítica, respectivamente. Os gnaisses compõem-se de quartzo, plagioclásio $\left(A n_{20-35}\right), k$-feldspato, microclínio, hornblenda, biotita, magnetita, apatita e zircão (ANEXO If). O feldspato está caulinizado e sericitizado, e o epidoto e moscovita preenchem micro-veios como resultado de alteração hidrotermal.

Entre os megacristais de quartzo, k-feldspato pertítico e plagioclásio desenvolve-se uma fase cristalina mais fina constituida por quartzo, plagioclásio, microclínio e k-feldspato e cristais glomeroporfiriticos de biotita e hornblenda, junto com magnetita, apatita e zircão. Os intercrescimentos principais são mirmequiticos, formados entre os megacristais de k-feldspato, vermiformes entre quartzo e biotita, pertíticos bead com 1 a $50 \%$ da fase sódica inserida em microclínio e k-feldspato, e antipertíticos. Os cristais grandes de plagioclásio e k-feldspato contem inclusões de quartzo anedral (lâmina $\mathrm{V}$-198).

A associação mineral típica é quartzo + plagioclásio + microclínio + hornblenda \pm biotita da fácies anfibolito de alta temperatura. Não se descarta que estas rochas atingiram a fácies 
granulito, uma vez que k-feldspato mesopertitico foi identificado. O protolito do ortognaisse corresponde a um biotita-hornblenda granito.

\subsection{Granulitos do Vergel}

Os granulitos com textura granoblástica são máficos (lâminas D-986, V-309, D-806 banda máfica) e félsicos (lâminas V-332, Gr-29, D-806 banda felsica), com niveis onde predomina kfeldspato, plagioclásio e quartzo em relação a piroxênio e hornblenda, e niveis onde concentram-se em maior quantidade os minerais máficos. Os minerais essenciais são: plagioclásio $\left(A n_{23-41}\right)$, quartzo, k-feldspato, ortopiroxênio, e às vezes egirina, hornblenda, biotita e granada. Como acessórios aparecem titanita, magnetita, zircão, apatita e monazita (ANEXO II).

O metamorfismo das rochas máficas atingiu a fácies granulito e apresenta as seguintes associações, plagioclásio + augita + granada (de alta pressão) e plagioclásio + augita + ortopiroxênio (de mais baixa pressão). Estas associações localizam-se numa faixa, onde ocorre a reação (1) que separa o piroxênio- granulito entre 5-7 Kbar, dos granada - granulito de pressão superiores a 5-7 Kbar (BUCHER \& FREY, 1994).

$$
\begin{aligned}
& 4 \mathrm{MgSiO}_{3}+1 \mathrm{CaAl}_{2} \mathrm{Si}_{2} \mathrm{O}_{8}=1 \mathrm{CaMgSi}_{2} \mathrm{O}_{6}+1 \mathrm{SiO}_{2}+1 \mathrm{Mg}_{3} \mathrm{Al}_{2} \mathrm{Si}_{3} \mathrm{O}_{12} \quad \text { reação (1) } \\
& \mathrm{En}^{+} \mathrm{An}_{\mathrm{N}}=\mathrm{Di}+\mathrm{Qtz}+\operatorname{Prp}
\end{aligned}
$$

Nem todas as rochas máficas contêm associações minerais da fácies granulito, algumas outras apresentam associação plagioclásio + hornblenda + clinopiroxênio \pm biotita da fácies anfibolito superior. Nestas rochas geralmente a hornblenda forma-se por rehidratação a partir do piroxênio (PRANCHA 2 - Foto 1). A formação de hornblenda se dá pelas reações (2) e (3) para rochas granulíticas com ou sem granada, respectivamente, de acordo com os diagramas da FIGURA 3, os quais exibem as possiveis associações encontradas em rochas ricas em $\mathrm{Fe}$ na zona de transição anfibolito-granulito.

$$
\begin{array}{ll}
H b|+Q t z=G r t+O p x+C p x+P|+H_{2} O & \text { reação (2) } \\
H b|+Q t z=O p x+C p x+P|+H_{2} O & \text { reação (3) }
\end{array}
$$

Os protolitos dos granulitos máficos são possivelmente rochas magmáticas básicas. Entretanto, não se descartam protolitos vulcânicos básicos ou subvulcânicos. As rochas félsicas, com composições mais ácidas, são principalmente de afinidade charnockítica, 
mangerítica e enderbítica.

Os gnaisses félsicos (lâminas D-982, V-290) estão constituídos principalmente por: plagioclásio, quartzo, k-feldspato e menores quantidades de biotita, hornblenda, granada, clinopiroxênio e microclínio (ANEXO II); localmente observa-se ortoclásio transformando-se em microclínio na borda. Esta transformação sugere que o feldspato potássico formado a maior temperatura possivelmente inverteu-se para microclinio durante o resfriamento. Os gnaisses félsicos que contêm hornblenda e biotita (lâmina V-314) sugerem uma origem ígnea, mas não pode ser descartada uma origem sedimentar. A associação quartzo + plagioclásio + clinopiroxênio + hornblenda \pm biotita, dos gnaisses com maior conteúdo de máficos é típica da transição entre a fácies anfibolito superior e granulito (BUCHER \& FREY, 1994).

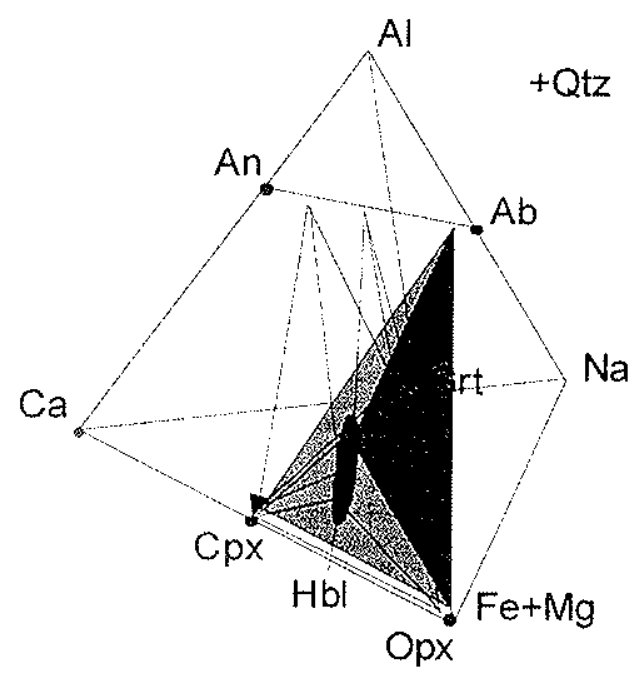

FIGURA 3. Diagrama ACFN de coexistência de hornblenda em rochas de transição de fácies anfibolito-granulito, tomado de SPEAR (1985), para rochas máficas ricas em $\mathrm{Fe}$ onde são mostradas as associações $\mathrm{Hbl}+\mathrm{Grt}+\mathrm{Opx}+\mathrm{Pl}, \mathrm{Hbl}+\mathrm{Grt}+\mathrm{Cpx}+\mathrm{Pl}$ e $\mathrm{Hbl}+\mathrm{Grt}+\mathrm{Cpx}+\mathrm{Opx}$.

Os anfibolitos, granoblásticos e de granulação média a grossa, estão compostos por hornblenda verde, plagioclásio com geminação da Lei da Albita, biotita castanha e em menor quantidade quartzo. Adicionalmente o quartzo forma intercrescimentos simplectíticos com biotita e hornblenda, além de se apresentar como inclusões arredondadas em hornblenda. $O$ protolito corresponde a hornblendito.

Em geral, uma feição característica das rochas desta unidade é o feldspato potássico pertítico (com 20 a $45 \%$ de fase sódica) e ocasionalmente mesopertítico com pertitas stringlets e strings, originadas por exsolução durante o metamorfismo na fácies granulito (PRANCHA 2 Foto 2). Às vêzes, os cristais de feldspato pertítico apresentam dois sistemas de pertitas de diferentes tamanhos, um muito fino com distribuição regular, e outro, mais grosso, elipsoidal e 
irregular (pertita flame, PRANCHA 2 - Foto 3). As duas fases pertíticas refletem estados de dissolução a diferentes temperaturas, o primeiro gerado a temperatura mais elevada, e o outro formado substituição em estado sub-sólido, conforme observado por RODRIGUEZ (1985). Outros intercrescimentos típicos são os antipertíticos bead com < $1 \%$ ortoclásio em plagioclásio, mirmequíticos (PRANCHA 2 - Foto 4) nas bordas de plagioclásio, simplectíticos entre hornblenda-quartzo e biotita-quartzo, e arranjos que incluem inclusões de quartzo em feldspatos, e granada poikiloblástica com quartzo e biotita.

\subsection{Gnaisse das Margaritas}

Os paragnaisses desta unidade são principalmente quartzo-feldspáticos com biotita, granada \pm sillimanita e clinopiroxênio, cujos protolitos são semi-pelíticos (lâminas Z-365, Gr-15, e amostra Gr-15p). Os principais minerais são: quartzo, plagioclásio, k-feldspato, biotita vermelha e granada, em menor quantidade microclinio com geminação em grade, clinopiroxênio (augitaegirina), sillimanita e magnetita, e como acessórios zircão, apatita e monazita (ANEXO II). A granada contém grandes inclusões ovais de quartzo e nas margens possui contatos lobados com este mesmo mineral (PRANCHA 2 - Foto 5). A forma irregular do quartzo e a continuidade óptica das duas fases sugerem que a granada e o quartzo cresceram juntos num arranjo microestrutural típico do metamorfismo prógrado (WATERS, 2001).

Os granulitos enderbíticos (lâminas C-32, C-271) são similares aos encontrados nos Granulitos do Vergel; constituem-se de ortopiroxênio, plagioclásio, granada e ocasionalmente hornblenda e biotita.

Os gnaisses são meta-máficos (meta-hornblenditos e meta-gabro-noritos) e meta-félsicos (lâminas C-299, C-302). Atingiram o metamorfismo de fácies anfibolito de alta temperatura com paragêneses de hornblenda + plagioclásio + ortopiroxênio \pm biotita para os máficos, e de quartzo + plagioclásio + microclínio para os gnaisses de composição félsica. Os anfibolitos apresentam textura gnáissica com remanescentes de textura hipidiomórfica, e constituem-se de hornblenda pardo-esverdeada, plagioclásio, clinopiroxênio e biotita verde. Seu protolito é hornblenda gabro e sua paragênese plagioclásio + hornblenda + clinopiroxênio indica que esta rocha atingiu a fácies anfibolito de alta temperatura.

Os fundidos anatécticos (leucossomas 1, niveis félsicos do gnaisse migmatítico, Lâmina Z-365) podem ser produzidos durante a descompressão por meio da reação (4) que involucrou fases hidratadas (biotita) em pelitos. Sillimanita, biotita, quartzo e k-feldspato aparecem do lado esquerdo desta reação, na qual a biotita quebra em ausência de fluidos, e por fusão parcial 
gera o leucossoma constituído por granada, microclínio e fundido (PRANCHA 2 - Foto 6 , PRANCHA 3 - Foto 1).

$B \dagger+S i l+Q \dagger z \pm K f s=G r \dagger+M c+$ fundido $\quad$ reação (4)

As paragêneses minerais de melanossoma e leucossoma constituem um forte argumento indicativo da fusão parcial, complementadas com as evidências seguintes observadas em afloramento e lâmina:

- A granada geralmente está concentrada nos gnaisses leucossomáticos, formando um nível enriquecido (PRANCHA 1 - Fotos 4 e 5, PRANCHA 2 - Foto 6).

- Inclusões de sillimanita residual ocorrem dentro de granada e k-feldspato (PRANCHA 3 Fotos 2 e 3 ).

Segundo Powell; Ashworth \& Brown (apud KRIEGSMAN \& HENSEN, 1998) a proximidade entre o leucossoma e o mesossoma restítico indica que pelo menos parte do fundido cristalizou in situ, em conseqüência os minerais e o fundido puderam reagir em determinado grau. A associação biotita sillimanita e moscovita que corta os gnaisses (PRANCHA 2 - Foto 6, PRANCHA 3 - Foto 1) pode formar-se por reação retrograda de fundido cristalizado in situ (KRIEGSMAN, 2001). Este mecanismo faz com que o leucossoma, produto de fusão, libere a água responsável pela hidratação das associações minerais nas encaixantes. Num segundo estágio a água reage com as fases sólidas (microclínio e granada) para formar simplectitas laminares de biotita verde e plagioclásio nos quartzo-plagioclásio gnaisses (Lâmina Gr-15) (PRANCHA 3 - Fotos 4 e 5) segundo a reação (5). Conforme Brown \& Raith; Stevens; Raith \& Harley (apud SAWYER, 1999) as texturas produzidas por estas reações têm sido utilizadas para deduzir a trajetória P-T durante o resfriamento metamórfico.

$\mathrm{Kfs}+\mathrm{Gr} \dagger+\mathrm{H}_{2} \mathrm{O}=\mathrm{B} \dagger$ verde $+\mathrm{Pl}+\mathrm{Q} \nmid z$ reação retrógrada (5)

Estreitos filmes de plagioclásio e plagioclásio mirmequítico, produtos da reação (5), localizamse ao redor da granada $e$ ao longo dos interstícios dos cristais, e são evidências texturais do resfriamento acompanhado por perda de pressão (PRANCHA 3-Foto 6).

Os granito-gnaisses (leucossoma 2, Lâmina $\mathrm{Gr}$-15a) constituídos de quartzo, feldspatos e biotita foram formados durante as condições da fácies anfibolito pela associação plagioclásio + quartzo + biotita + microclínio pertítico. 
Os principais intercrescimentos nas rochas desta unidade são antipertíticos bead de plagioclásio com 1 a 10\% de microclínio (PRANCHA 3 - Foto 7). Na mesma amostra, localmente observam-se, pertitas a mesopertitas tipo stringlets, strings e bead, e antipertitas com conteúdos de microclínio na fase sódica até $1 \%$. Outros intercrescimentos são mirmequiticos formados nas bordas do plagioclásio, e menos freqüentes, micrográficos, simplectíticos de quartzo-biotita, e arranjos poikiloblásticos de hornblenda - quartzo e granada quartzo. 


\section{PRANCHA 2}

FOTO 1. Associação mineral ortopiroxênio-plagioclásio-biotita-homblenda do plagioclásioquartzo gnaisse com biotita. Hornblenda formada pela quebra do ortopiroxênio. Nícois paralelos, lâmina C-299.

FOTO 2. K-feldspato mesopertítico do granulito charnockítico. Observa-se a deformação do k-feldspato, lâmina V-332.

FOTO 3. Pertitas flame de substituição desenvolvidas na borda do k-feldspato em contato com plagioclásio, lâmina Z-365-2.

FOTO 4. Plagioclásio mirmequítico entre cristais do $k$-feldspato pertítico. Observa-se os dois sets de pertitas no k-feldspato, uma muito fina regular e a outra mais grossa e elipsoidal, lâmina D-806.

FOTO 5. Granada com inclusões arredondadas de quartzo; nas margens contatos lobados com quartzo. Feições típicas de metamorfismo prógrado. Lâmina Gr-15.

FOTO 6. Metatexito constituído por melanossoma (Me) e leucossoma 1 (Le), lâmina Z-365. O leucossoma consiste de quartzo, ortoclásio pertítico, plagioclásio e biotita sem orientação preferencial. O leucossoma 1 fino consiste de quartzo, microclínio, granada e biotita. Niveis máficos $(M)$ de sillimanita e biotita seguindo a segunda foliação cortam o mesossoma 

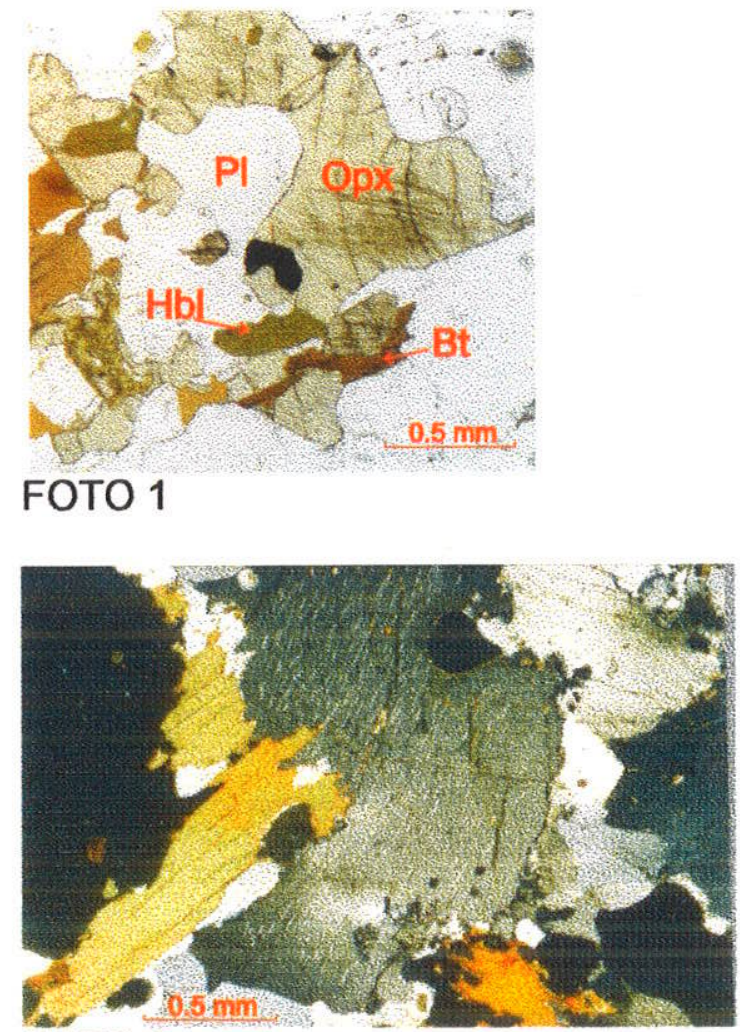

FOTO 2
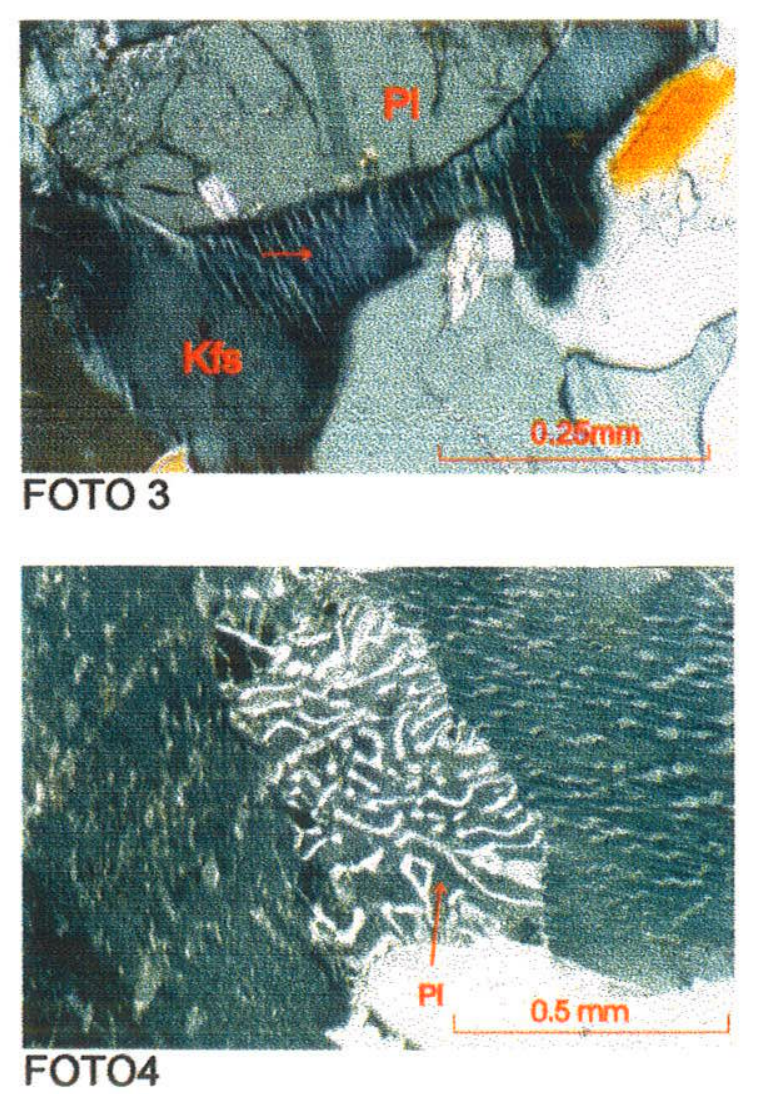
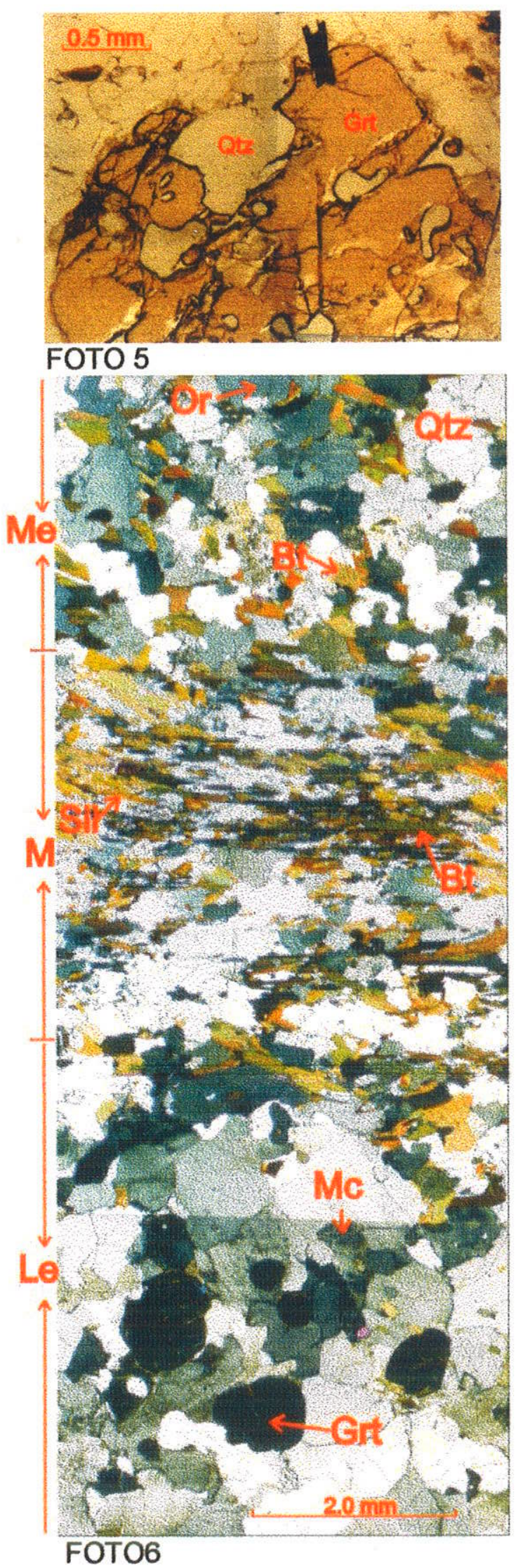


\section{PRANCHA 3}

FOTO 1. Detalhe da associação sillimanita e biotita da lâmina Z-365. A sillimanita altera-se a argila e entre os intersticios dos cristais de biotita gera-se moscovita.

FOTO 2. Detalhe do leucossoma 1 da lâmina Z.-365. Granada com inclusões de sillimanita, esta última como resquício de uma fase mineral pre-migmatítica.

FOTO 3 Detalhe do leucossoma 1 da lâmina Z-365. K-feldspato com inclusão de sillimanita, esta última como resquício de uma fase mineral pre-migmatitica. $O \mathrm{k}$-feldspato inverte-se a microclínio nas bordas do cristal.

FOTO 4. Simplectitas de biotita e plagioclásio formadas às expensas da granada e microclínio. O arranjo simplectítico está reabsorvendo a granada. Nicois paralelos, lâmina Gr-15.

FOTO 5. Simplectitas de biotita e plagioclásio formadas às expensas da granada e microclínio. O arranjo simplectítico está reabsorvendo a granada. Nícois cruzados, lâmina Gr-15.

FOTO 6. Detalhe da simplectita, lâmina Gr-15. Borda de plagioclásio ao redor da granada restante da reação mineral entre k-feldspato, granada, biotita, plagioclásio e quartzo mais água.

FOTO 7. Plagioclásio antipertítico com desenvolvimento de pertitas em duas direções refletindo processos diferentes. As pertitas sub-horizontais seguem a direção da biotita (indicada pela seta) fomada durante a segunda foliação do granulito. Lâmina C-32.

FOTO 8 Desenvolvimento de biotita (Bt2) e plagioclásio (PI2) numa segunda foliação, bordejando o plagioclásio (PI1). O plagioclásio (PI1) faz parte da associação mineral granulitica (Grt-Opx-Hbl-PI-Qtz) desta rocha máfica. Lâmina C-32 


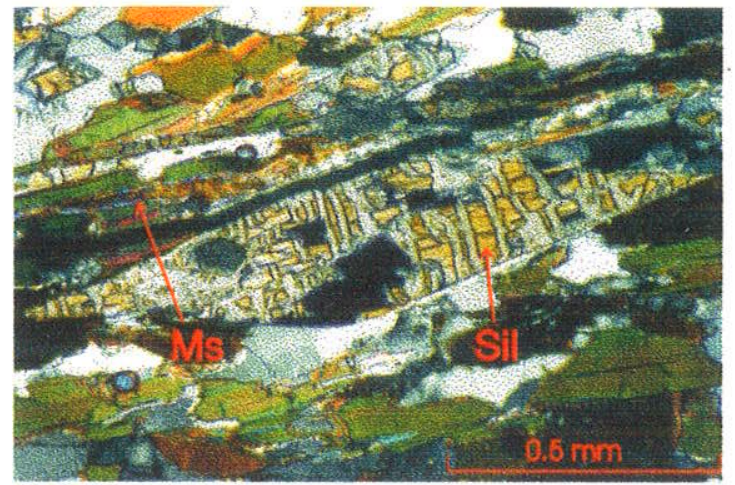

FOTO 1
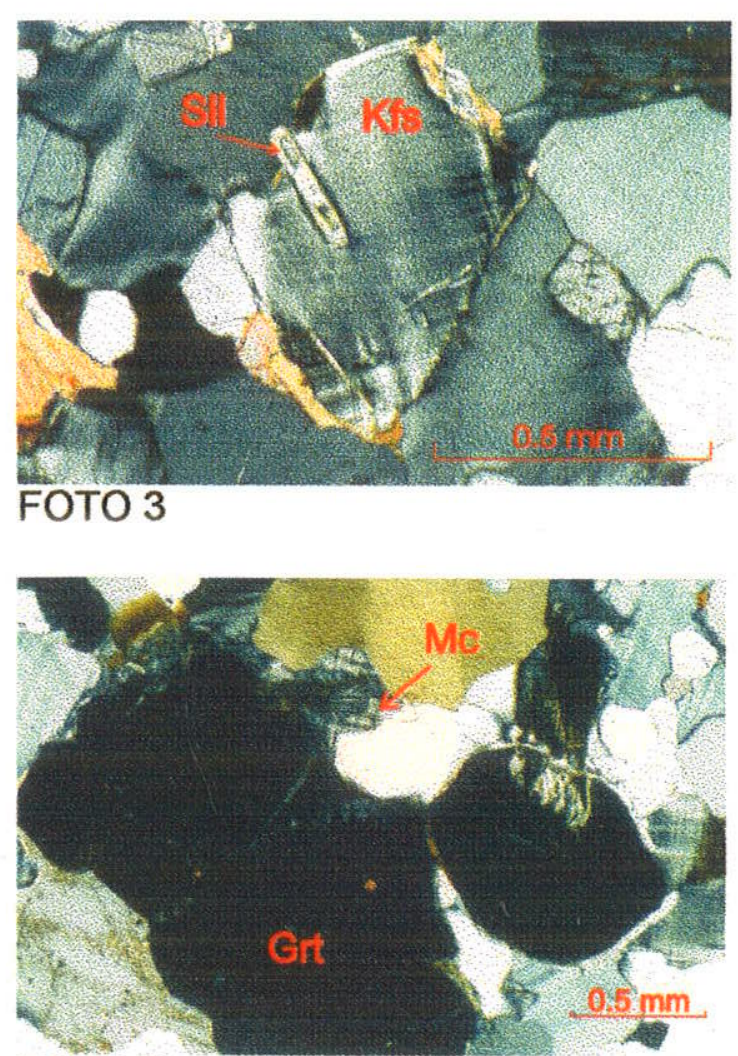

FOTO 5

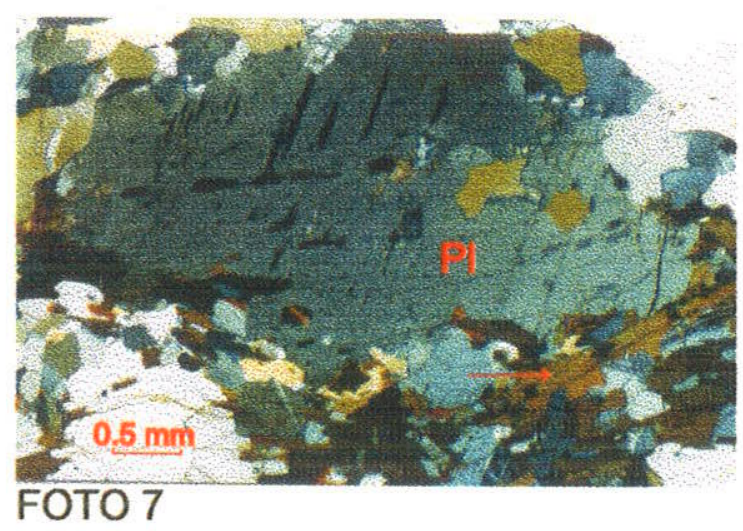

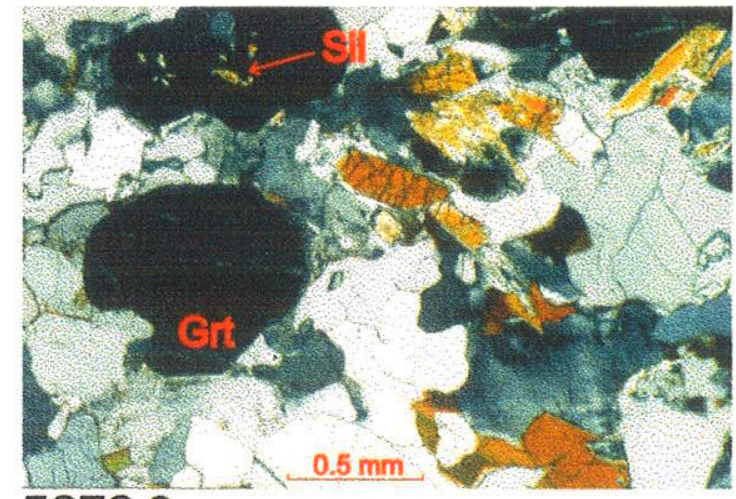

FOTO 2

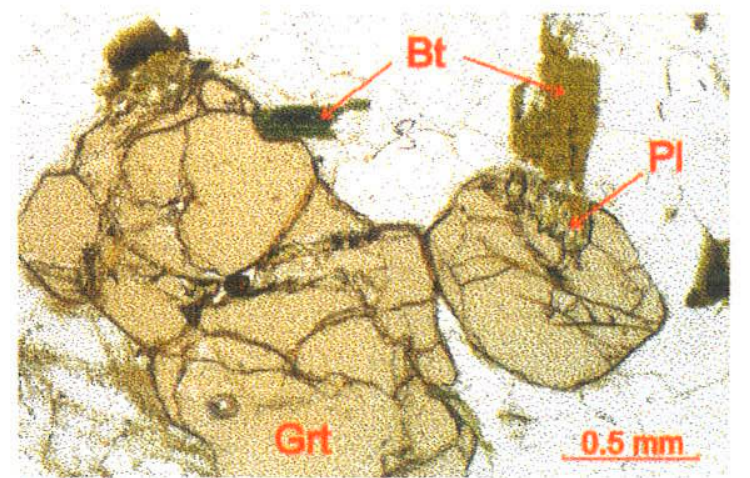

FOTO 4

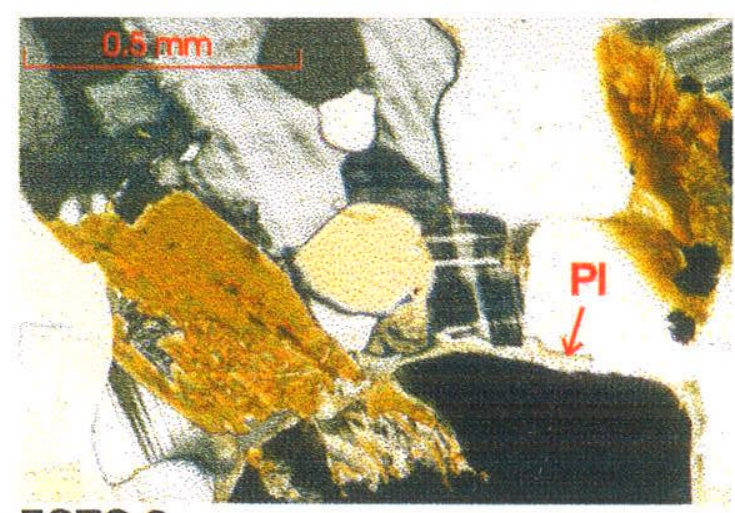

FOTO 6

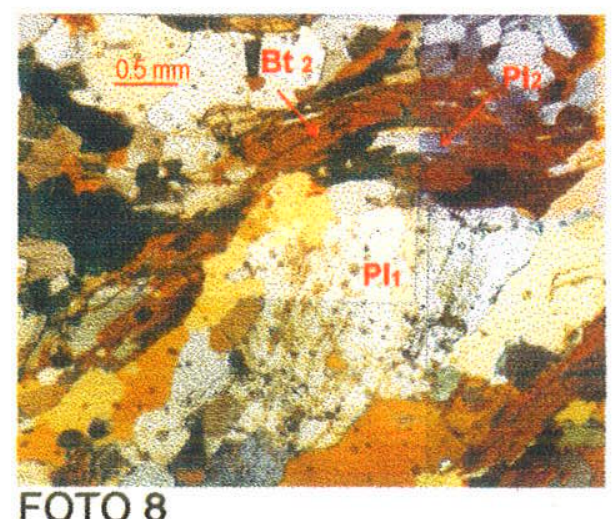




\section{GEOTERMOBAROMETRIA}

Os estudos geotermobarométricos provêm dados quantitativos no campo P-T (pontos especificos) que refletem as condições locais de equilibrio do sistema químico em algum ponto da sua historia, através das fases minerais participantes de reações sensitivas à pressão ou temperatura. Além disso, revelam as mudanças nas condições $\mathrm{P}-\mathrm{T}(\Delta \mathrm{P}, \Delta T)$ da rocha por meio das variações químicas deduzidas de estudos de zonação ou inclusões minerais.

A informação geotermobarométrica permite obter trajetórias Pressão-Temperatura de paragêneses minerais em equilibrio, re-equilíbrio e desequilibrio em rochas metamórficas de fácies anfibolito e granulito, e derivar o modelo de evolução metamórfica para um orógeno especifico (BROWN, 1993). Nesta pesquisa o conceito do metamorfismo progressivo como a mudança seqüencial do grau de metamorfismo deixado pelas associações ao longo do gradiente metamórfico foi substituido pela visão dinâmica, na qual as rochas individuais (ex. THOMPSON \& ENGLAND, 1984) e minerais (ex. SPEAR \& SELVERSTONE, 1983) podem ser usados para obter trajetórias no campo P-T. Estes caminhos podem ser relacionados ao ambiente tectônico responsável pela orogênese (ENGLAND \& THOMPSON, 1984).

Apesar das rochas da transição anfibolito-granulito terem minerais geotermobarômetros, a interpretação da trajetória P-T nem sempre é simples, uma vez que as altas taxas de difusão catiônica impedem geralmente a preservação dos segmentos prévios da trajetória do metamorfismo progressivo. Levando em consideração esta limitação na interpretação da evolução tectono-metamórfica, compararam-se os segmentos da trajetória retrógrada de metamorfismo obtidos para as rochas pertencentes ao Granulitos do Vergel e Gnaisse das Margaritas. Na escolha das amostras para as análises, selecionaram-se as que melhor preservaram o equilíbrio característico das fácies granulito e anfibolito, e as que exibiram alguma feição textural de desequilibrio, indicada por substituição dos minerais metamórficos de alta $\mathrm{P}-\mathrm{T}$ pelas fases minerais retrógradas.

\subsection{Métodos geotermobarométricos}

Realizaram-se 291 análises químicas pontuais por microssonda eletrônica em 5 lâminas delgadas (V-332, Gr-15, C-32, Z-365-1, Z-365-2). As análises estão distribuidas nos seguintes minerais: 107 em granada, 84 em biotita, 47 em piroxênio, 32 em plagioclásio, 13 em anfibólio, 4 em ilmenita, 2 em k-feldspato e 2 em moscovita (ANEXO III). Com o propósito de determinar 
as variações dos seus componentes, os estudos foram efetuados em seções transversais centro-borda

As composições químicas foram obtidas por meio de equipamento JEOL JXA 8600 , no Laboratório de Microssonda Eletrônica do Instituto de Geociências da Universidade de São Paulo. Utilizou-se corrente de aceleração de feixe de elétrons de $20 \pm 0,1 \eta \mathrm{A}$, tensão de $15 \mathrm{kV}$ e diâmetro do feixe de elétrons de $10 \mu \mathrm{m}$ para análises de feldspatos e $5 \mu \mathrm{m}$ para os demais minerais.

As fórmulas estruturais de granada, ortopiroxênio, biotita e plagioclásio foram obtidas com o programa Minpet 2.02, assumindo $\mathrm{Fe}^{2+}$ como $\mathrm{Fe}_{\text {total. }}$ No caso da biotita, a classificação foi feita com base em 22 cargas positivas assumindo um grupo anion idealizado, de acordo com às recomendações de RIEDER et al. (1998) para análises de microssonda sem determinação de $\mathrm{H}_{2} \mathrm{O}$. As composições de anfibólios foram recalculadas a 23 átomos de oxigênio, com a base estequiométrica da média de todos os cátions, exceto $\mathrm{Na}$ e K, normalizados a 15 e de todos os cátions, exceto $\mathrm{Ca}, \mathrm{Na}$ e $\mathrm{K}$, normalizados a 13. Este procedimento foi testado com o programa NEWAMPHCAL para calcular as fórmulas estruturais de análises de anfibólios de microssonda segundo a classificação proposta pela International Mineralogical Association (IMA) de LEAKE et al. (1997).

Neste trabalho, Os dados geotermobarométricos foram obtidos com o programa TWQ (v. 2.02) de BERMAN (1991), que calcula multi-equilibrios com uma base de dados termodinâmica, internamente consistente, $e$ incorpora modelos de atividade-composição não ideal para granada (BERMAN, 1990), biotita (MCMULLIN et al., 1991), ortopiroxênio - ideal mixing (NEWTON, 1983), plagioclásio (FUHRMAN \& LINDSLEY, 1988), e inclui propriedades dos endmembers (BERMAN, 1988; 1990). O programa fornece pontos invariantes no campo $P-T$, nos interceptos de linhas bivariantes de equilibrio.

Os valores de P-T obtidos por meio do programa TWQ foram testados com o programa GPT de RECHÉ \& MARTINEZ (1996), que compila diversos termômetros e barômetros calibrados por diferentes autores. A comparação foi feita para litotipos de rocha de condições de metamorfismo anfibolito-granulito, levando em conta os limites químicos dos minerais empregados nos experimentos ou testes naturais.

Nas abreviações dos minerais empregados na apresentação dos dados geotermobarométricos, nas reações citadas no texto, nas descrições mineralógicas e petrológicas, e no tratamento dos 
dados isotópicos em tabelas e anexos adotou-se a simbologia de KRETZ (1983) complementada com a de SPEAR (1985) (ANEXO IV).

\subsection{Granulitos do Vergel}

\subsubsection{Química Mineral}

O granulito charnockítico (Lâmina V-332, ANEXO V) apresenta paragênese típica de metamorfismo de alto grau, dentro da transição fácies anfibolito superior a granulito.

A composição química média do núcleo da granada é almandina $72,8 \%$, piropo $17,4 \%$, grossularia $7,3 \%$, espessartita $2,1 \%$ e uvarovita $0,3 \%$. Este padrão composicional é resultado da homogeneização por difusão intracristalina atingida em altas temperaturas, a qual tende a apagar qualquer zoneamento composicional inicial (HODGES, 1991), e mantém-se constante até nos lugares vizinhos das inclusões de biotita. A composição na borda da granada em contato com biotita varia para almandina $71,6 \%$, piropo $14 \%$, grossularia $11,9 \%$, espessartita $2,1 \%$ e uvarovita $0,2 \%$ (FIGURA 4), evidenciando uma reaçăo retrógrada por um sutil decrescimento da razão $\mathrm{Fe} / \mathrm{Fe}+\mathrm{Mg}$. A granada tem perfil composicional caracterizado por ter núcleos homogêneos mais ricos em $\mathrm{Fe}$ e $\mathrm{Mg}$ e bordas ricas em Ca e pobres em $\mathrm{Mg}$, sem mudança no teor de Mn, como mostra a FIGURA 5.
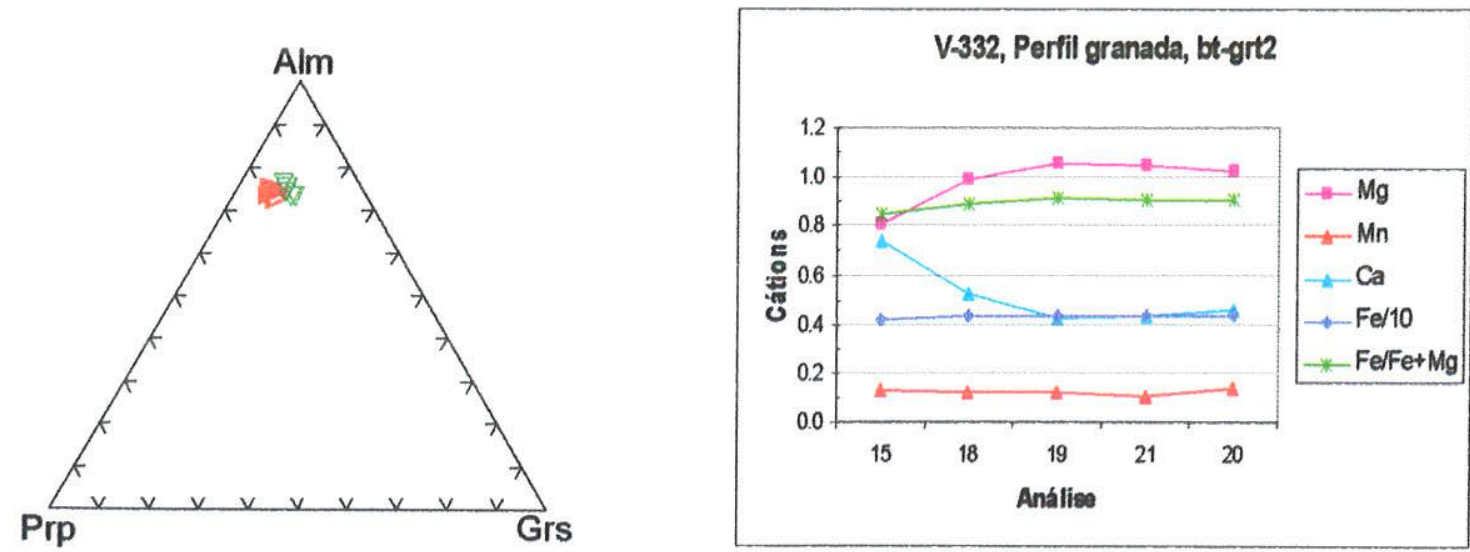

FIGURA 4 - Composição da granada do granulito chamockítico V-332: $\triangleright$ = núcleo e posições intermediárias, $\nabla=$ borda em contato com biotita.

FIGURA 5 - Perfil composicional bt-grt2 da granada V-332: análises: $15=$ contato granadabiotita, 18 e 21 = posições intermediárias, 19 = núcleo, e 20 = borda.

A ferrosilita não apresenta zoneamento químico nítido, mas quando está em contato com granada observa-se um leve enriquecimento de Fe em suas bordas (FIGURA 6). Já o feldspato da lâmina consiste de plagioclásio e ortoclásio. O plagioclásio da matriz (andesina sódica), do mesmo modo que o piroxênio, não varia em sua composição. O ortoclásio é 
pertítico, e suas exsoluções finas apresentam composiçao entre a fase hospedeira e exsolvida (FIGURA 7).

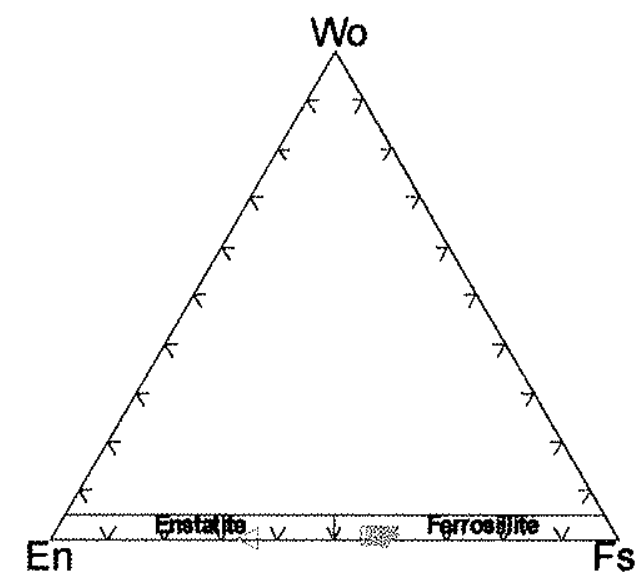

FIGURA 6 - Classificação do ortopiroxênio do granulito charnockitico V-332, análises 1-11 no perfil px-grt1: $=$ núcleo e posições intermediárias, $=$ borda em contato com granada, $=$ alteração.

Os valores de $\mathrm{Ti}$ variam substancialmente nos diversos tipos de biotita como mostra $\circ$ diagrama Ti/AI da FIGURA 8. Os teores mais altos de Ti, aproximadamente 0,70, são da biotita inserida na granada com $6,11 \% \mathrm{TiO}_{2}$ e valores de $\mathrm{X}_{\mathrm{Mg}}$ de 2,52; esta biotita não foi reequilibrada e representa as condições mais altas do metamorfismo de acordo com GUIDOTTI (1984) e SPEAR et al. (1990). Concentraçôes intermediarias de Ti, entre 0,54-0,64, observamse nos núcleos da biotita que estão em equilíbrio com granada e ferrosilita com 4,62-5,6\% $\mathrm{TiO}_{2}$ e valores de $X_{\mathrm{Mg}}$ de 2,48-2,63. Os teores mais baixos de $\mathrm{Ti}$, entre 0,51 . 0,52, são das bordas da biotita em contato com a granada e da biotita formada a partir de granada, ortopiroxênio e ilmenita com 4,44-4,46\% $\mathrm{TiO}_{2}$ e valores de $\mathrm{X}_{\mathrm{Mg}}$ de 2,34-2,89.
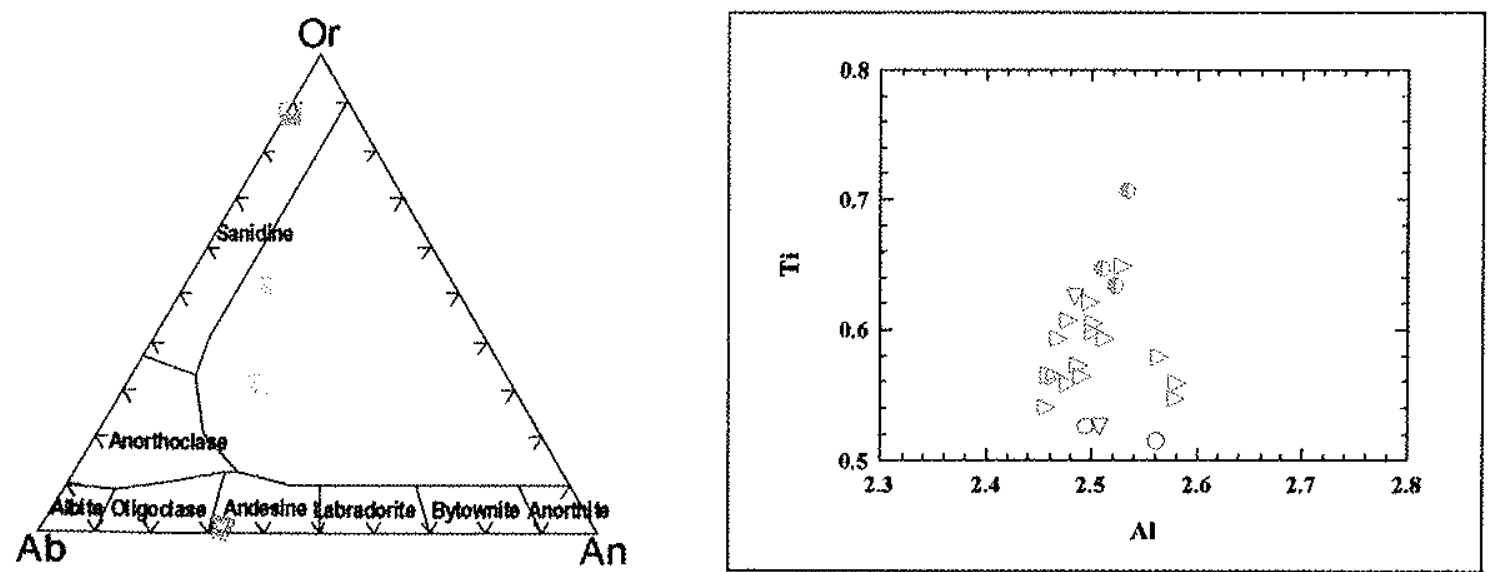

FIGURA 7 - Composição dos feldspatos do granulito charnockítico V-332: = ortoclásio pertítico, = pertita, $\nabla=$ contato plagioclásio-granada, $\nabla=$ núcleo do plagioclásio .

FIGURA 8 - Diagrama Ti/AI das biotitas do granulito charnockítico V-332: = inclusão em granada, = núcleo e posições intermediárias, $\square=$ borda em contato com granada, $0=$ formada pela quebra de granada e piroxênio. 


\subsubsection{Resultados geotermobarométricos}

Foi obtida uma estimativa das condições de temperatura e pressão próximas ao pico térmico do metamorfismo para o granulito charnockítico (Lâmina V-332) com ○ TWQ, com base no padrão composicional dos minerais da rocha, usando a composição do núcleo da granada com o núcleo do plagioclásio, e os núcleos da biotita ou a inclusão da biotita de alto Ti na granada (núcleo, associações V-332-1,2,3,5,6,7,9). A estimativa das condições metamórficas de reequilibrio foi obtida utilizando as composições da borda da granada e plagioclásio em contato com a biotita (borda, associações V-332-4,8,13,15). Os cálculos geotermobarométricos das associações núcleo e borda definem a parte retrógrada da trajetória antihorária no campo P.T, onde o decréscimo em Fe/Fe+Mg da granada implica num sutil incremento da temperatura, acompanhado de um aumento da pressão definido pelo aumento do teor de Ca na granada (FIGURA 9).

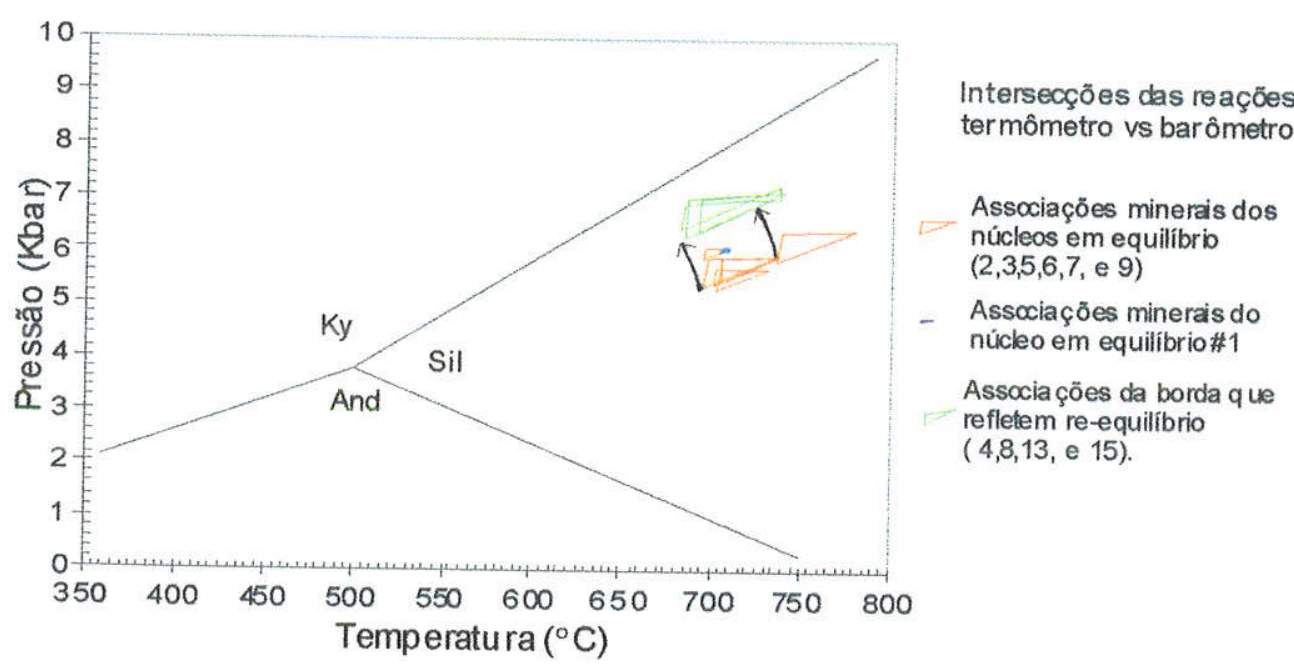

FIGURA 9 - Diagrama P-T do granulito chamockítico V-332 dos Granulitos do Vergel obtido com o TWQ do intercepto das reações entre plagioclásio-ortopiroxênio-granada-biotita quartzo. Ponto triplo $\mathrm{Al}_{2} \mathrm{SiO}_{5}$ de HOLDAWAY, 1971. As setas indicam a trajetória anti-horária.

A associação mineral em equilibrio do granulito (V-332-1) define um ponto de $700^{\circ} \mathrm{C}$ e $6 \mathrm{kbar}$, onde se intersectam as reações de equilibrio, baixo $\triangle \mathrm{P} / \Delta \mathrm{T}$ (geotermômetro) de troca $\mathrm{Fe}-\mathrm{Mg}$ entre Opx - Bt (6), Opx - Grt (7), Grt - Bt (8), e reações de alto $\Delta \mathrm{P} / \Delta \mathrm{T}$ (geobarômetro), Grt $\mathrm{Qtz}$ - Opx - PI (membros ferroso 9 e magnesiano 10), e a reação $\mathrm{Grt}$ - Bt - Qtz - Opx - PI (11) como mostra a FIGURA 10.

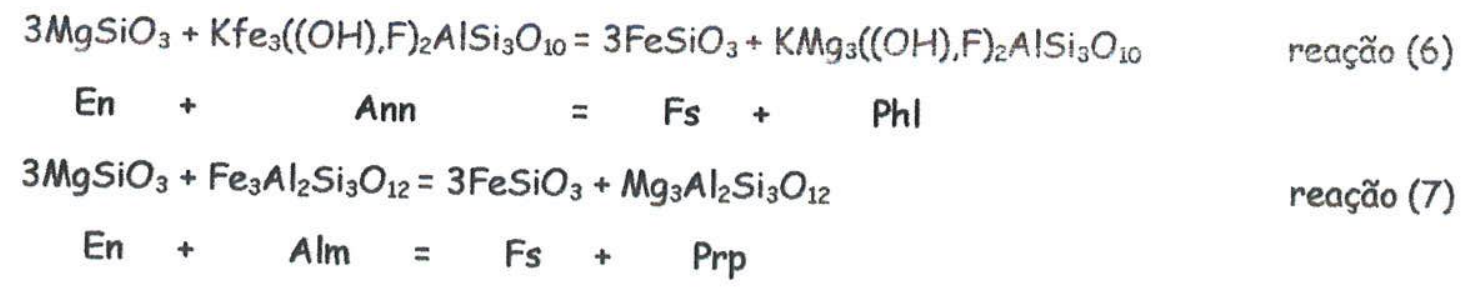


$\mathrm{Fe}_{3} \mathrm{Al}_{2} \mathrm{Si}_{3} \mathrm{O}_{12}+\mathrm{KMg}_{3}((\mathrm{OH}), \mathrm{F})_{2} \mathrm{AlSi}_{3} \mathrm{O}_{10}=\mathrm{Mg}_{3} \mathrm{Al}_{2} \mathrm{Si}_{3} \mathrm{O}_{12}+\mathrm{Kf} e_{3}((\mathrm{OH}), \mathrm{F})_{2} \mathrm{AlSi}_{3} \mathrm{O}_{10}$ reação (8) $\mathrm{Alm}+\mathrm{Phl}=\operatorname{Prp}+$ Ann

$2 \mathrm{Fe}_{3} \mathrm{Al}_{2} \mathrm{Si}_{3} \mathrm{O}_{12}+\mathrm{Ca}_{3} \mathrm{Al}_{2} \mathrm{Si}_{3} \mathrm{O}_{12}+3 \mathrm{SiO}_{2}=6 \mathrm{FeSiO}_{3}+3 \mathrm{CaAl}_{2} \mathrm{Si}_{2} \mathrm{O}_{8}$

reação (9)

$\mathrm{Alm}+\mathrm{Grs}+\mathrm{Qtz}=\mathrm{Fs}+\mathrm{An}$

$\mathrm{Ca}_{3} \mathrm{Al}_{2} \mathrm{Si}_{3} \mathrm{O}_{12}+2 \mathrm{Mg}_{3} \mathrm{Al}_{2} \mathrm{Si}_{3} \mathrm{O}_{12}+3 \mathrm{SiO}_{2}=6 \mathrm{MgSiO}_{3}+3 \mathrm{CaAl}_{2} \mathrm{Si}_{2} \mathrm{O}_{8}$

reação (10)

Grs $+\operatorname{Prp}+Q t z=E n+A n$

$2 \mathrm{Fe}_{3} \mathrm{Al}_{2} \mathrm{Si}_{3} \mathrm{O}_{12}+\mathrm{Ca}_{3} \mathrm{Al}_{2} \mathrm{Si}_{3} \mathrm{O}_{12}+2 \mathrm{KMg}_{3}\left((\mathrm{OH}), \mathrm{F}_{2} \mathrm{AlSi}_{3} \mathrm{O}_{10}+3 \mathrm{SiO}_{2}=6 \mathrm{MgSiO}_{3}+3 \mathrm{CaAl}_{2} \mathrm{Si}_{2} \mathrm{O}_{8}\right.$

$+2 \mathrm{Kfe}_{3}((\mathrm{OH}), \mathrm{F})_{2} \mathrm{AlSi}_{3} \mathrm{O}_{10}$

reação (11)

$\mathrm{Alm}+\mathrm{Grs}+\mathrm{Phl}+\mathrm{Qtz}=\mathrm{En}+\mathrm{An}+\mathrm{Ann}$

Os resultados obtidos com o programa TWQ foram testados com a geotermobarometria clássica, utilizando as mesmas associações minerais. Os cálculos geotermométricos tradicionais mostraram, em geral, temperaturas menores com o par granada-biotita comparadas com as obtidas da granada-ortopiroxênio. A pressão foi melhor contrastada com o barômetro de NEWTON \& PERKINS (1982) e BHATTACHARYA et al. (1991), com valores semelhantes para os equilibrios de $\mathrm{Fe}$ e $\mathrm{Mg}$ (barômetro granada-piroxênio-plagioclásioquartzo). Os valores P-T, para a associação V-332-1, definem um campo entre 4,8 e 5,55 Kbar e 685 e $740^{\circ} \mathrm{C}$, baseado nos termômetros granada-biotita de HODGES \& SPEAR (1982), PIGAGE \& GREENWOOD (1982), WILLIAMS \& GRAMBLING (1990), e termômetro entre granada-piroxênio de SEN \& BHATTACHARYA (1984), BHATTACHARYA et al. (1991), LAVRENTEVA \& PERCHUK (1990), e LAL (1993). Estas calibrações são as mais consistentes com os valores obtidos a traves do TWQ.

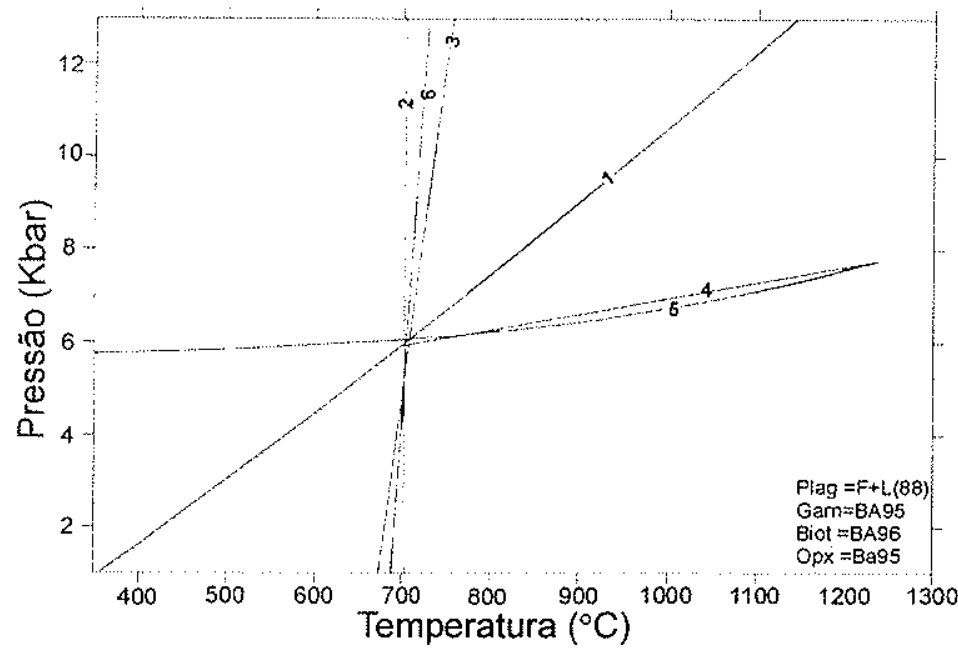

1): $2 \mathrm{Alm}+\mathrm{Grs}+3 \mathrm{aQtz}=6 \mathrm{Fs}+3 \mathrm{An}$

2): $3 E n+A n n=3 F s+P h l$

3): $3 \mathrm{En}+\mathrm{Alm}=3 \mathrm{Fs}+\mathrm{Prp}$

4): $2 \mathrm{Alm}+\mathrm{Grs}+2 \mathrm{Phl}+3 \mathrm{aQtz}=6 \mathrm{En}+3 \mathrm{An}+2 \mathrm{Ann}$

5): $\mathrm{Grs}+2 \mathrm{Prp}+3 \mathrm{aQtz}=6 \mathrm{En}+3 \mathrm{An}$

6): Alm + Phl $=$ Prp + Ann

FIGURA 10 - Resultados dos cálculos TWQ da associação mineral em equilíbrio V-332-1 do granulito charnockítico, usando os núcleos da granada, biotita, ortopiroxênio e borda do plagioclásio em contato com granada, mais quartzo. 
Os valores da geotermobarometria clássica das demais associações minerais (núcleo, associações $V$-332-2,3,5,6,7,9, e borda, associações 4,13 e 15) mostraram maior espalhamento que os valores do TWQ; contudo, registram o mesmo padrão de aumento da pressão dos equilibrios da borda com respeito aos núcleos (QUADRO 4)

QUADRO 4. TEMPERATURAS E PRESSÕES MÉDIAS DAS ASSOCIAÇÕES NÚCLEO (n) E BORDA (b) DA LÂMINA V-332 OBTIDAS POR GEOTERMOBAROMETRIA CLÁSSICA.

\begin{tabular}{|c|c|c|}
\hline Associações & $\mathrm{P}$ (Kbar) & $\mathrm{T}\left({ }^{\circ} \mathrm{C}\right)$ \\
\hline$V-332-2 n$ & $4,1-5,45$ & $690-790$ \\
\hline$V-332-3 n$ & $4,55-5,55$ & $665-740$ \\
\hline$V-332-5 n$ & $4,2-5,35$ & $685-762,5$ \\
\hline$V-332-6 n$ & $4,47-5,6$ & $705-774$ \\
\hline$V-332-7 n$ & $4,3-5,6$ & $690-774$ \\
\hline$V-332-9 n$ & $4,85-6,0$ & $735-798$ \\
\hline$V-332-4 n$ & $6,67-8,75$ & $640-770$ \\
\hline$V-332-13 b$ & $7,12-8,7$ & $665-770$ \\
\hline$V-332-15 b$ & $6,82-8,67$ & $635-750$ \\
\hline
\end{tabular}

O resseting do termômetro granada-biotita com relação a granada-piroxênio é obvio já que a maioria destes termômetros, GOLDMAN \& ALBEE (1977) e FERRY \& SPEAR (1978), são calibrados para rochas pelíticas e semi-pelíticas da fácies anfibolito medio. As inconsistências observadas no termômetro granada-biotita permitiram a BOHLEN \& ESSENE (1980) afirmar que as calibrações deste par mineral são inadequadas para avaliar a temperatura em terrenos metamórficos de alto grau, nos quais as variações de Ti e Al nas biotitas são mais extremas a temperaturas acima de $650^{\circ} \mathrm{C}$. Esta limitação foi considerada no termômetro de INDARES \& MARTIGNOLE (1985), no qual se considera o conteúdo de Ti e Al nas biotitas, entretanto a composição das biotitas empregadas nos experimentos não permitiu correção satisfatória para uma composição modal mais abrangente.

\subsection{Gnaisse das Margaritas}

Desta unidade foram escolhidas três amostras: quartzo-plagioclásio gnaisse (Lâmina Gr-15); quartzo-plagioclásio-biotita gnaisse migmatitico bandado, com níveis de minerais micáceos (mesossoma) e félsicos (leucossoma) (Lâmina Z-365); granulito máfico (Lâmina C-32). As respectivas descrições petrográficas estão compiladas no ANEXO V. 


\subsubsection{Química Mineral}

O quartzo-plagioclásio gnaisse e o gnaisse migmatítico, localizados no mesmo afloramento (Lâminas Gr-15 e Z-365), pertencem à subfácies sillimanita-almandina da fácies anfibolito superior. O granulito máfico (Lâmina C-32) esta dentro da zona de transição fácies anfibolito a granulito, cuja hornblenda foi gerada pela quebra de hiperstênio e granada.

\section{Lâminas Gr-15 e Z-365:}

As granadas com inclusões de quartzo destas duas lâminas exibem núcleos homogêneos com composições médias que aproximam-se a uma mistura ternária almandina-piropo-grossulária com subordinadas concentrações de espessartita (QUADRO 5, FIGURAS 11 e 13); entretanto, na lâmina Z-365 o núcleo da granada é mais rico em Mg por ter sido produto de fusão parcial (ROBINSON, 1991). Os cristais nas bordas apresentam zoneamento com incremento em Fe, decréscimo em Mg e teores de Mn e Ca quase constantes, exceto na lâmina $\mathrm{Gr}-15$, onde há um incremento sutil de Mn (FIGURAS 12 e 14). Este padrão composicional de aumento de $\mathrm{Fe} / \mathrm{Fe}+\mathrm{Mg}$ nas bordas da granada é provocado principalmente pela troca $\mathrm{Fe}-\mathrm{Mg}$ dos cristais em contato com a biotita durante o resfriamento.
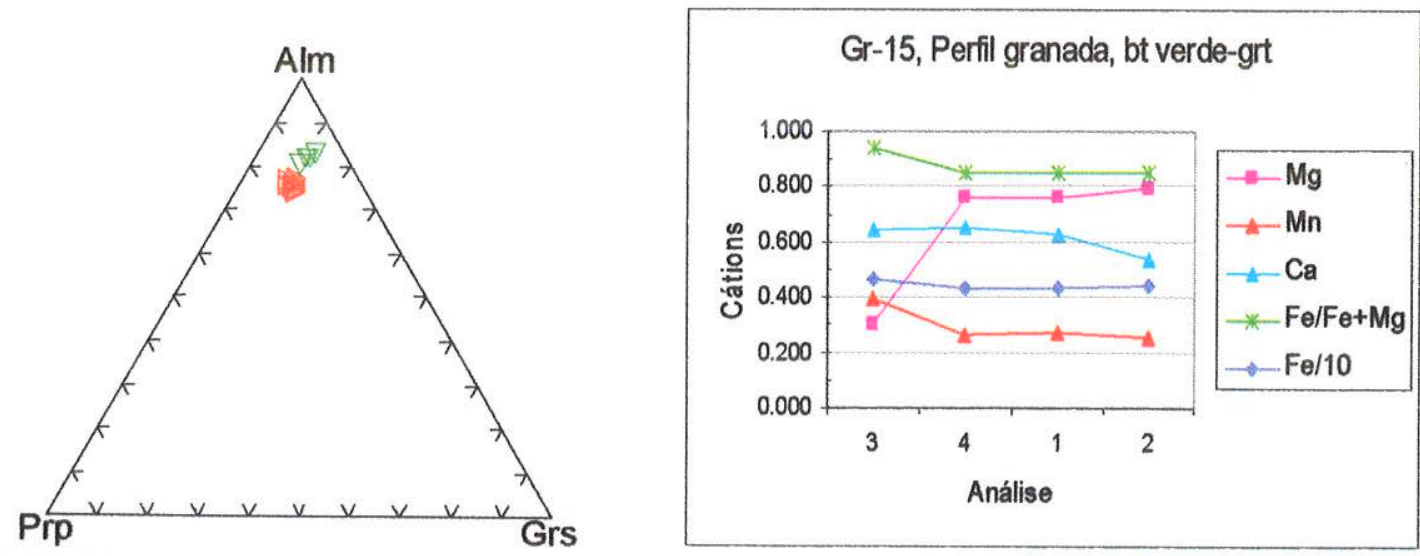

FIGURA 11 - Composição da granada do quartzo-plagioclásio gnaisse $\mathrm{Gr}-15$ : $\nabla=$ borda em contato com biotita, $\triangleright=$ núcleo e posições intermediárias.

FIGURA 12 - Perfil composicional bt verde-grt da granada do quartzo-plagioclásio gnaisse $\mathrm{Gr}$ 15: análises 3 = contato granada-biotita, 1,2 e 4 = núcleo e posições intermediárias.

QUADRO 5. COMPOSIÇÕES MÉDIAS DOS NÚCLEOS DAS GRANADAS DO GNAISSE DAS MARGARITAS, LÂMINAS Gr-15, Z-365, C-32

\begin{tabular}{|l|c|c|c|c|}
\hline & Almandina (\%) & Piropo (\%) & Grossulária (\%) & Espessartita (\%) \\
\hline Gr-15 & 72 & 13 & 11 & 4 \\
\hline Z-365 & 71 & 24 & 3 & 2 \\
\hline C-32 & 61 & 19 & 15 & 5 \\
\hline
\end{tabular}



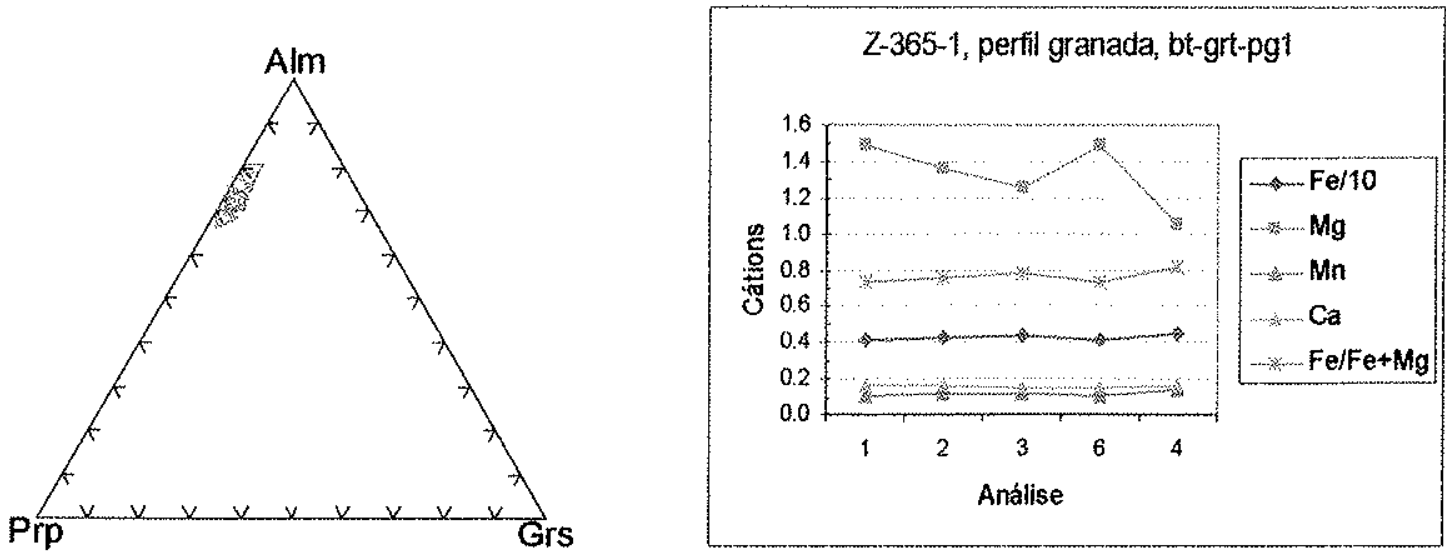

FIGURA 13 - Composição da granada do gnaisse migmatítico Z-365-1:: = contato granadaplagioclásio, $\nabla=$ contato granada-biotita, $D=$ núcleo e posições intermediarias.

FIGURA 14 - Perfil composicional bt-grt-pg1 da granada do gnaisse migmatítico Z-365-1: análises $1-3=$ núcleo, $4=$ contato granada-biotita, $6=$ borda.

As biotitas da lâmina $\mathrm{Gr}-15$ exibem diferenças no teor de $\mathrm{Ti}$ como ilustrado no diagrama $\mathrm{Ti} / \mathrm{Al}$ (FIGURA 15). A biotita verde apresenta os maiores conteúdos de Ti, representativos das condições metamórficas mais altas, com valores de $2,8-3,17 \% \mathrm{TiO}_{2}$, teores de $\mathrm{Ti} \sim 0,36$ e $\mathrm{X}_{\mathrm{Mg}}$ de $\sim 1,64$. Já as biotitas da matriz e as simplectíticas apresentam composiçöes que refletem re-equilíbrio com valores entre $1,34-2,28 \% \mathrm{TiO}_{2}$, teores de $\mathrm{Ti}$ de $0,15-0,27$ e $\mathrm{X}_{\mathrm{Mg}}$ de $1,74-1,91$. Descartaram-se as análises das biotitas verde e simplectítica com conteúdos de Ti menor a 0,1 por tratar-se de pequenos cristais cuja composição diferia com respeito às biotitas maiores, permitindo maior fluxo de $\mathrm{Fe}$ e $\mathrm{Mg}$. As biotitas grandes comportaram-se analogamente a reservatórios infinitos, nos quais a composição não muda com o tempo (SPEAR et al., 1990). Na lâmina Z-365, a biotita associada à sillimanita e aquela da matriz contêm maior $\mathrm{Ti}$ com valores entre $0,46-0,59\left(4,0-5,1 \% \mathrm{TiO}_{2}\right)$ e $\mathrm{X}_{\mathrm{Mg}}$ de $2,24-2,37$. A biotita em contato com granada reflete condições de re-equilibrio, com conteúdos de Ti 0,28 $0,31\left(\sim 2,6 \% \mathrm{TiO}_{2}\right)$ e $X_{\text {Mg }}$ de 2,54-3,04 (FIGURA 16).

Os plagioclásios das lâminas $\mathrm{Gr}-15$ e Z-365 são oligoclásios. Na lâmina $\mathrm{Gr}-15$, os cristais da matriz e aqueles em contato com granada são cálcicos, já o plagioclásio simplectítico e aquele presente ao redor da granada têm um leve enriquecimento em $\mathrm{Na}$. Estas observações implicam que o plagioclásio, na fase retrógrada, chega a ser mais albítico. Na lâmina Z-365 o oligoclásio é pouco mais sódico, para os cristais corroídos, com respeito aos cristais em contato com granada e biotita.

\section{Lâmina C-32:}

Nesta rocha a granada é mais rica no componente grossulária que as das rochas Gr-15 \& Z- 

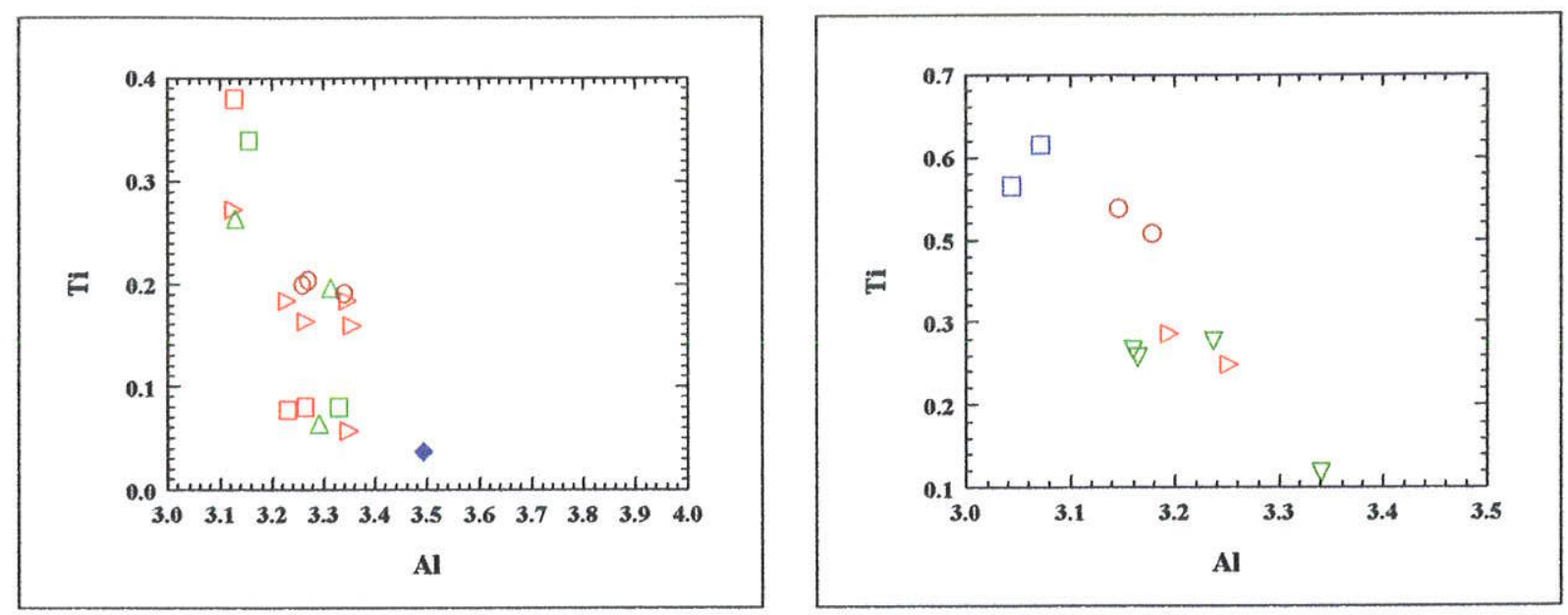

FIGURA 15 - Diagrama Ti/Al das biotitas do quartzo-plagioclásio gnaisse Gr-15: $\square$ = biotita verde do núcleo, $\square=$ biotita verde em contato com granada, $\triangleright=$ biotita simplectítica do núcleo, $\nabla=$ biotita simplectítica em contato com granada,,$\quad=$ biotita da matriz, $=$ biotita cloritizada. FIGURA 16 - Diagrama Ti/AI das biotitas do gnaisse migmatítico Z-365-1, $\square=$ biotita associada à sillimanita, $\circ=$ biotita da matriz, $\triangleright=$ núcleo e posições intermediárias, $\nabla=$ contato granadabiotita.

365 (QUADRO 5), e a sua composição não muda muito com respeito às análises de núcleo eborda (FIGURA 17). Apresenta núcleo homogêneo, com diminuição de Mg, sutil incremento em $\mathrm{Fe}$ e $\mathrm{Ca}$ nas bordas dos cristais em contato com a biotita e nas análises próximas a algumas inclusões de biotita, onde a troca química Fe-Mg foi efetiva durante o resfriamento (FIGURA 18). Este zoneamento com aumento relativo de $\mathrm{Fe}, \mathrm{Fe} / \mathrm{Fe}+\mathrm{Mg}$ e $\mathrm{Ca}$, e decréscimo de $\mathrm{Mg}$ nas bordas dos cristais de granada em contato com biotita, reflete mudança química durante a queda da temperatura.
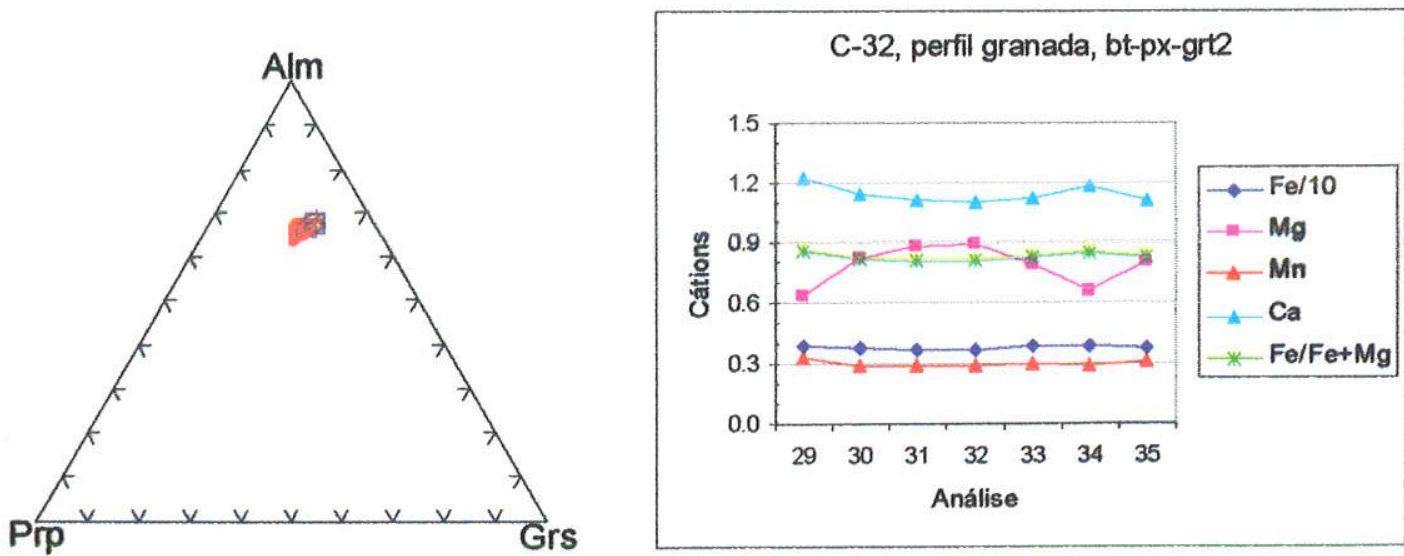

FIGURA 17 - Composição da granada do granulito máfico C-32: $\square$ = contato granadaortopiroxênio, $O=$ granada em contato com inclusão de biotita, $\nabla=$ contato granada-biotita, $\triangleright=$ núcleo e posições intermediárias, $+=$ inclusão de granada em ortopiroxênio, $\diamond=$ contato granada hornblenda

FIGURA 18 - Perfil composicional bt-px-grt2 da granada do granulito máfico C-32: análises 29 = contato granada-ortopiroxênio, 30,31,32 e 35 = posições intermediárias e núcleo, 33 e 34 = contato granada-inclusão de biotita. 
A FIGURA 19 representa um diagrama Ti/Al para todas as biotitas analisadas. Algumas inclusões de biotita nas granadas, onde não houve troca química de $\mathrm{Fe}-\mathrm{Mg}$ entre as duas fases, preservaram as condições de maior grau metamórfico, com conteúdos de $\mathrm{Ti} \sim 0,67$ e $X_{M g} \sim 2,42$. As demais biotitas foram re-equilibradas durante o desenvolvimento da foliação, com valores de $\mathrm{Ti} \sim 0,53-0,65$ e $\mathrm{X}_{\mathrm{Mg}} \sim 2-2,35$.

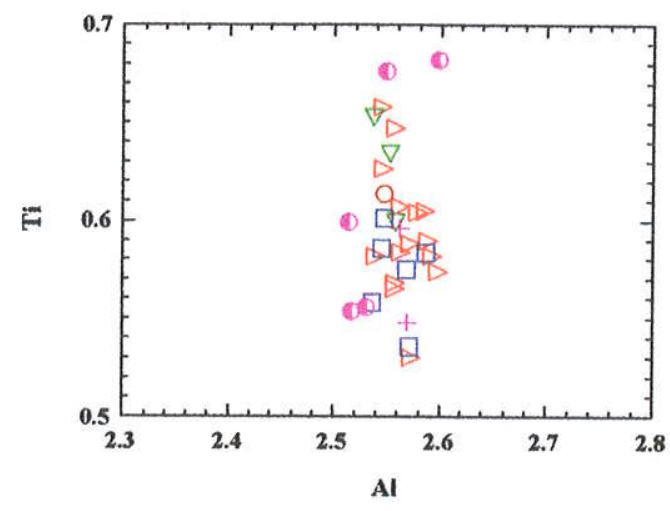

FIGURA 19 - Diagrama Ti/AI de todas as biotitas $\mathrm{C}-32, \quad=$ inclusões em granada, + = contato biotita piroxênio, $\nabla=$ contato biotita granada , $\triangleright=$ núcleo e posições intermediarias, $0=$ contato biotita hornblenda,$\square=$ biotita sin-deformação.

O ortopiroxênio corresponde a ferrosilita e o anfibólio a ferropargasita (FIGURA 20) sem mudança de composição; ambos os plagioclásios, pré e sin-deformação, são andesina.

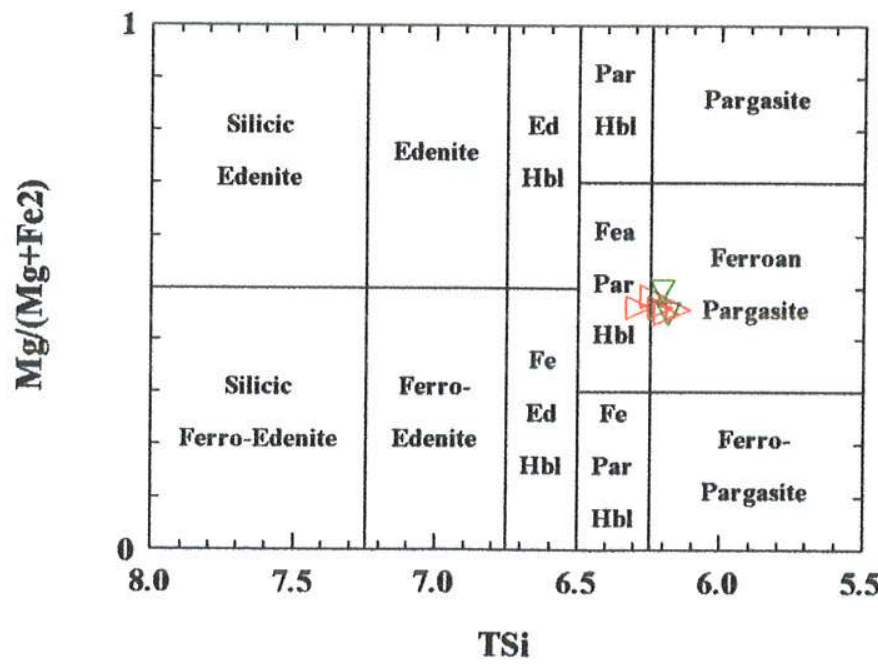

FIGURA 20 - Composição do anfibólio do granulito máfico C-32. $\nabla=$ anfibólio em contato com biotita, $\triangleright=$ núcleo e posições intermediarias.

\subsubsection{Resultados geotermobarométricos}

Para o quartzo-plagioclásio gnaisse (Lâmina $\mathrm{Gr}$-15) obtiveram-se temperaturas de $\sim 890^{\circ} \mathrm{C}$ (núcleo, associações $\mathrm{Gr}-15-11,11 \mathrm{~A}, 12,14)$. por meio do termômetro granada-biotita das 
análises: biotita-matriz e granada-núcleo. Esta temperatura foi confirmada por meio das associações (Gr-15-1,3,6) correspondentes aos núcleos das biotitas em contato com granada $\left(\sim 825-850^{\circ} \mathrm{C}\right)$. Condições de menor temperatura foram obtidas com as análises das biotitas simplectiticas com as respectivas bordas da granada, que re-equilibraram entre $625-640^{\circ} \mathrm{C}$ (borda, associações Gr-15-4,7). Na FIGURA 21, observam-se os valores médios destas temperaturas.

Os cálculos com a termometria clássica, utilizando as calibrações de THOMPSON (1976); HODGES \& SPEAR (1982); GANGULY \& SAXENA (1984); PERCHUK \& LAVRENT'EVA (1983) e INDARES \& MARTIGNOLE (1985) confirmam os valores obtidos com O TWQ. A temperatura média para as associações núcleo, segundo estes termômetros, esta compilada no QUADRO 6.

QUADRO 6. TEMPERATURA MÉDIA DAS ASSOCIAÇÕES NÚCLEO (n) DA LÂMINA Gr-15 OBTIDAS POR GEOTERMOBAROMETRIA CLÁSSICA.

\begin{tabular}{|l|c|c|}
\hline \multicolumn{1}{|c|}{ Associações } & $\mathrm{T}\left({ }^{\circ} \mathrm{C}\right)$ para 4 Kbar & $\mathrm{T}\left({ }^{\circ} \mathrm{C}\right)$ para 13 Kbar \\
\hline Gr-15-11n & 815 & 870 \\
\hline Gr-15-12n & 834 & 890 \\
\hline Gr-15-1n & 805 & 860 \\
\hline Gr-15-3n & 794 & 850 \\
\hline Gr-15-6n & 750 & 800 \\
\hline
\end{tabular}

No gnaisse migmatítico (Lâmina Z-365) observa-se uma temperatura de $\sim 800^{\circ} \mathrm{C}$ para as associações núcleo, (Z-365-1,3,4,6,11,12), conseguidas com o termômetro granada-biotita, utilizando as análises do núcleo da granada com a biotita da matriz. Já as temperaturas de reequilibrio obtidas das análises das bordas da granada em contato com biotita refletem valores de $\sim 650^{\circ} \mathrm{C}$, para as associações da borda, Z-365-2,8,9 (FIGURA 21). Os cálculos geotermobarométricos com 0 TWQ da paragênese mineral granada com inclusão de sillimanita - biotita - feldspato potássico - quartzo, e das associações núcleo (Z-365-1,3,4,6,11,12), definem um campo P-T entre $780-826^{\circ} \mathrm{C}$ e 6,3-8,0 Kbar (FIGURA 21). Nesse intervalo P.T obtido, além do termômetro granada-biotita, a temperatura foi confirmada pela reação de fusão (12), e a pressão pela reação de troca química entre PI-Grt-Sil-Qtz (13) como mostra a FIGURA 22. 


$$
\begin{gathered}
\mathrm{KMg}_{3}\left((\mathrm{OH}), \mathrm{F}_{2} \mathrm{AlSi}_{3} \mathrm{O}_{10}+2 \mathrm{SiO}_{2}+\mathrm{Al}_{2} \mathrm{SiO}_{5}=\mathrm{Mg}_{3} \mathrm{Al}_{2} \mathrm{Si}_{3} \mathrm{O}_{12}+\mathrm{KAlSi} 3 \mathrm{O}+\mathrm{H}_{2} \mathrm{O}\right. \\
\mathrm{Phl}+\mathrm{Qtz}+\mathrm{Sil}=\mathrm{Prp}+\mathrm{kfs}+\text { água } \\
3 \mathrm{CaAl}_{2} \mathrm{Si}_{2} \mathrm{O}_{8}=\mathrm{Ca}_{3} \mathrm{Al}_{2} \mathrm{Si}_{3} \mathrm{O}_{12}+\mathrm{SiO}_{2}+2 \mathrm{Al}_{2} \mathrm{SiO}_{5}
\end{gathered}
$$

$$
A_{n}=\text { Grs }+Q t z+\text { Sil }
$$

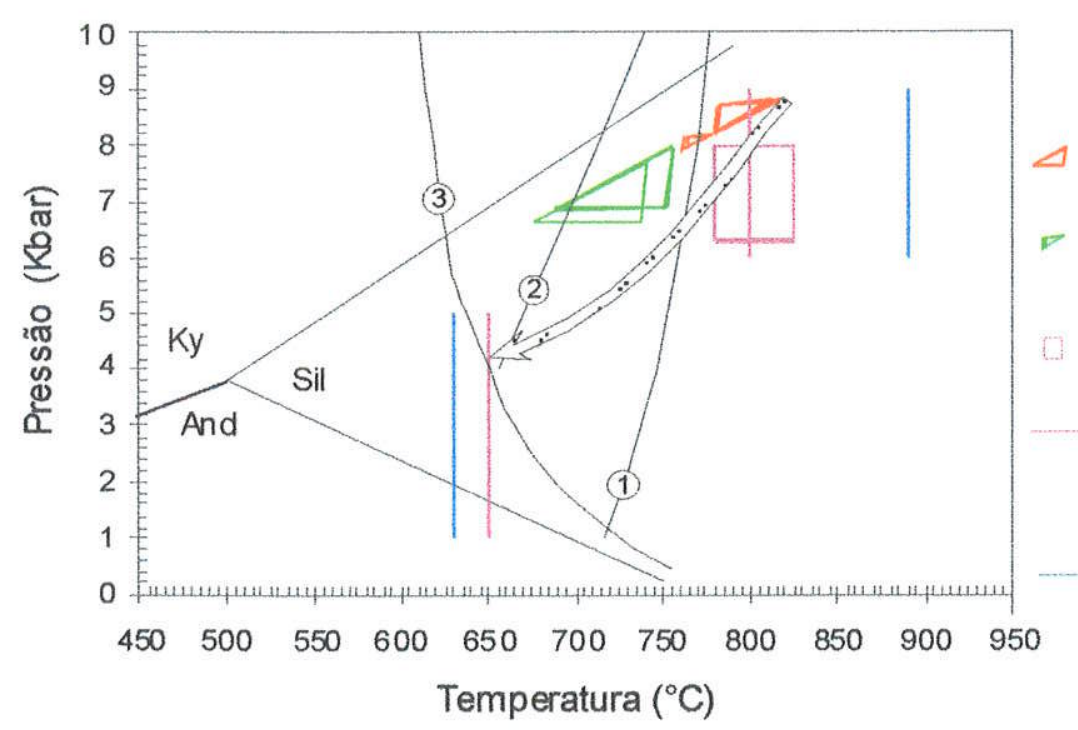

Inters ecções das reações termôm etro vs barômetro

\section{Granulito máfico (C-32)}

Associações minerais dosnúcleos em equilibrio de grt-opx-bt-pl, C-32 - 3,7,8 e 11

Associações em re-equilbrio de grt-opx-bt-pl, C-32 - 4, 16 e17.

Gnaisse migmatitico (Z-365)

Associações minerais dos núcleos de grt-silbt-kfs-qtz, media de Z-365 - 1,3,4,6,11,12

Termômetro granada-biotita, de alta e bai xa temperatura

Quartzo-plagioclásio gnaisse (Gr-15)

Termômetro granada-biotita, de alta e baixa temperatura

FIGURA 21 - Diagrama P-T do granulito máfico, gnaisse migmatítico, e quartzo-plagioclásio gnaisse pertencentes ao Gnaisse das Margaritas, obtido com o TWQ. 1) reação de fusãodesidratação $b t+p l+\mathrm{Al}_{2} \mathrm{SiO}_{5}+q \mathrm{tz}=\mathrm{grt+kfs} \mid+$ fundido de LE BRETON \& THOMPSON (1988), 2) reação $m s+a b+q t z=k f s+s i l+L$ de Petö (1976) apud LE BRETON \& THOMPSON (1988), 3) Curva de cristalização do granito de Huang \& Wyllie (1973) apud LE BRETON \& THOMPSON (1988). Ponto triplo $\mathrm{Al}_{2} \mathrm{SiO}_{5}$ de HOLDAWAY (1971). A seta indica a trajetória de descompressão aproximadamente isotérmica-ITD (near-isothermal decompression) em sentido horário.

Os cálculos da temperatura média para as associações núcleo (Z-365-1,3,4,6,11,12), obtidos com o termômetro granada-biotita de THOMPSON (1976), HODGES \& SPEAR (1982), PERCHUK \& LAVRENT'EVA (1983), LAVRENT'EVA \& PERCHUK (1981), e HOLDAWAY \& LEE (1977), confirmam os resultados do TWQ e estão compilados no QUADRO 7.

Para o granulito máfico (Lâmina C-32) obtiveram-se duas regiões no campo P-T, por meio da geotermobarometria núcleo-borda no TWQ, utilizando as análises que preservam as condições de equilíbrio granulítico de inclusão de biotita em granada com os núcleos da granada, ortopiroxênio e plagioclásio (núcleo, associações C-32-3,7,8,11), e as que refletem condições de re-equilibrio paragenético granulítico com as bordas dos mesmos minerais (borda, associações C-32-4,16,17). Condições metamórficas entre $751-778^{\circ} \mathrm{C}$ e $7,7-8,1$ kbar para as associações núcleo, e entre $688-752^{\circ} \mathrm{C}$ e $6,8-7,9 \mathrm{Kbar}$ para as associações borda. A 
relação entre as duas regiões define uma trajetória near-isothermal decompression (ITD) que reflete a porção retrógrada do metamorfismo com perda de temperatura e de pressão (FIGURA 21). Os cálculos geotermobarométricos com o TWQ, baseados nas reações dos geotermômetros $(6,7$ e 8$)$ e geobarômetros $(9,10)$, confirmam estas regiões no campo $P_{-}$, , e na FIGURA 23 observam-se as reações de equilibrio desta amostra (associação mineral C-327).

QUADRO 7. TEMPERATURA MÉDIA DAS ASSOCIAÇÕES NÚCLEO (n) DA LÂMINA Z-365 OBTIDAS POR GEOTERMOBAROMETRIA CLÁSSICA.

\begin{tabular}{|l|c|c|}
\hline \multicolumn{1}{|c|}{ Associações } & $\mathrm{T}\left({ }^{\circ} \mathrm{C}\right)$ para $4 \mathrm{Kbar}$ & $\mathrm{T}\left({ }^{\circ} \mathrm{C}\right)$ para 10 Kbar \\
\hline$Z-365-1 n$ & 795 & 818 \\
\hline$Z-365-3 n$ & 798 & 820 \\
\hline$Z-365-4 n$ & 802 & 825 \\
\hline$Z-365-6 n$ & 793 & 815 \\
\hline$Z-365-11 n$ & 800 & 823 \\
\hline$Z-365-12 n$ & 797 & 820 \\
\hline
\end{tabular}

Da paragênese mineral granada-horblenda-biotita obteve-se uma temperatura do par granadabiotita entre $770-790^{\circ} \mathrm{C}$ das associações núcleo $(\mathrm{C}-32-1,2,14,15,17 \mathrm{~A}, 18)$ e de $730-740{ }^{\circ} \mathrm{C}$ para as associações borda (C-32-4,16,17). Neste cálculo não foi incluída a hornblenda ferropargasítica, visto que esta é formada pela quebra de hiperstênio, possivelmente em condições de menor temperatura com respeito às associações minerais formadas durante o metamorfismo granulítico (granada-hiperstênio-biotita).

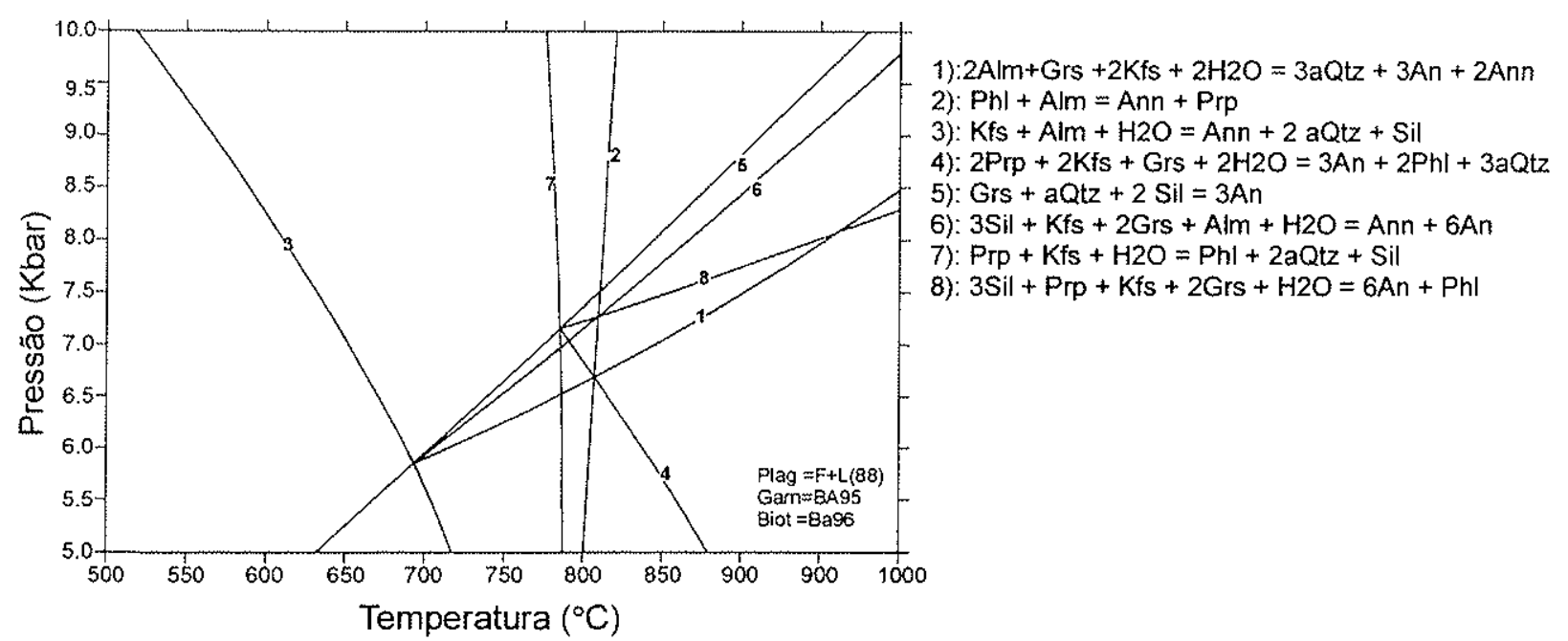

FIGURA 22 - Resultados dos cálculos TWQ da associação mineral Z-365-12 do gnaisse migmatítico, usando a paragênese granada - sillimanita - biotita - feldspato potássico - quartzo 


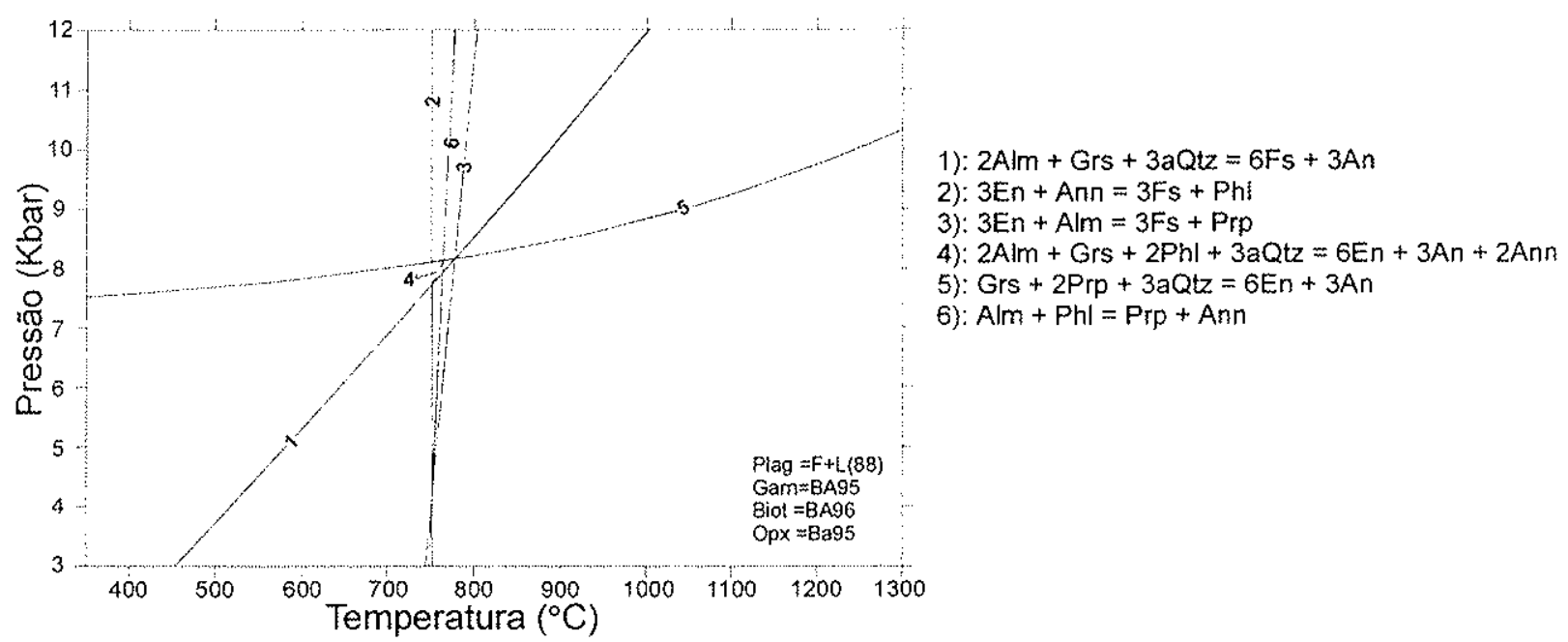

FIGURA 23 - Resultados dos cálculos TWQ da associação mineral C-32-7do granulito máfico, usando os núcleos da granada, ortopiroxênio e plagioclásio, inclusões de biotita mais quartzo.

A tendência na trajetória com o TWQ foi testada com a geotermobarometria clássica, utilizando as mesmas associaçōes minerais. Os cálculos geotermométricos tradicionais mostraram em geral temperaturas menores com a associação granada-biotita do que as obtidas da granadaortopiroxênio. A temperatura média obteve-se segundo as calibrações granada-biotita de HODGES \& SPEAR (1982), PERCHUK et al. (1985), DASGUPTA et al. (1991), e granadapiroxênio de SEN \& BHATTACHARYA (1984), BHATTACHARYA et al. (1991), LAVRENT'EVA \& PERCHUK (1990), e LAL (1993). A pressão foi verificada com o barômetro de BHATTACHARYA et al. (1991) de Fe e Mg, e NEWTON \& PERKINS (1982) (QUADRO 8).

QUADRO 8. TEMPERATURA-PRESSĀO MÉDIA DAS ASSOCIAÇÕES NÚCLEO (n) E BORDA (b) DA LÂMINA C 32 OBTIDAS POR GEOTERMOBAROMETRIA CLÁSSICA.

\begin{tabular}{|l|c|c|}
\hline \multicolumn{1}{|c|}{ Associações } & $\mathrm{P}$ (Kbar) & $\mathrm{T}\left({ }^{\circ} \mathrm{C}\right)$ \\
\hline $\mathrm{C}-32-3 n$ & $6,37-7,25$ & $717-757$ \\
\hline$C-32-7 n$ & $6,37-7,27$ & $717-761$ \\
\hline$C-32-8 n$ & $6,67-8,02$ & $745-798$ \\
\hline$C-32-11 n$ & $6,65-8,30$ & $742-857$ \\
\hline$C-32-4 b$ & $5,15-6,57$ & $610-718$ \\
\hline$C-32-16 b$ & $5,34-6,87$ & $618-734$ \\
\hline$C-32-17 b$ & $5,34-6,85$ & $620-734$ \\
\hline
\end{tabular}




\subsection{Considerações geotermobarométricas}

Para o Gnaisse das Margaritas obteve-se uma trajetória (ITD), a qual indica a porção retrógrada de um caminho horário. Na parte superior está definida pelos campos no espaço P. $\mathrm{T}$ da amostra $\mathrm{C}-32$. Na parte inferior pelos termômetros de baixa temperatura das amostras Gr-15 e Z-365, e pelo desenvolvimento de uma segunda associação de Bt-Sil-Ms (lâmina Z-

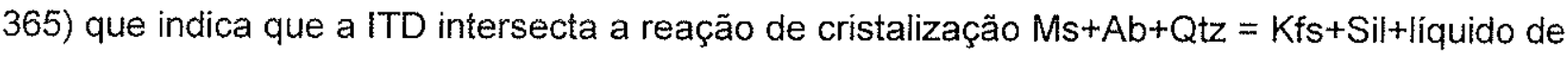
Petö (1976) apud LE BRETON \& THOMPSON (1988) a uma pressão maior que 4 kbar (FIGURA 21). A trajetória (ITD) da parte oriental do orógeno é confirmada por evidência textural, como o desenvolvimento de biotita-plagioclasio simplectíticas a partir de granada e moats de plagioclásio em gnaisses e granulitos félsicos, respectivamente. As duas texturas, geradas durante o resfriamento, refletem queda de temperatura, acompanhada por uma relativa queda de pressão.

As condições de maior temperatura obtidas para os gnaisses Gr-15 e Z-365, desta unidade, estão acima dos $760^{\circ} \mathrm{C}$ que correspondem à temperatura sob a qual inicia-se a fusãodesidratação da biotita de acordo a reação $\mathrm{Bt}+\mathrm{PI}+\mathrm{Sil}+\mathrm{Qtz}=\mathrm{Kfs}+\mathrm{Grt+fundido} \mathrm{de} \mathrm{LEBRETON} \mathrm{\&}$ THOMPSON, 1988. Contudo, as temperaturas obtidas para estas duas amostras podem estar superestimadas, como e o caso do valor de $890^{\circ} \mathrm{C}$ do gnaisse $\mathrm{Gr}-15$ (FIGURA 21). Nesta rocha, alem da reação de fusão-desidratação, ocorreu a reação retrograda $\mathrm{Grt}+\mathrm{KfS}+\mathrm{H} 2 \mathrm{O}=$ Sil+Bt, durante a qual a granada é reabsorvida pelo fluido aquoso e suas bordas se enriquecem em $\mathrm{Mn}$ e $\mathrm{Fe}$ e se empobrecem em $\mathrm{Mg}$. Este processo de difusão, embora não consiga apagar completamente o registro composicional inicial da granada, oblitera a composição inicial das fases da matriz, como por ex. da biotita (ROBINSON, 1991). Neste tipo de reação retrograda, geralmente não sobra registro da biotita que originalmente esteve em equilíbrio com a granada, e dessa forma os valores da temperatura conseguidos da granadanúcleo e biotita-matriz, são sempre mais altos do que a verdadeira temperatura máxima (ROBINSON, 1991). Por esta razão, o valor de maior temperatura para o gnaisses Gr-15 não é considerado no caminho definido pela trajetória ITD.

Em contraste, na parte ocidental do orógeno (amostra V-332) a trajetória retrógrada P-T registra aumento da pressão com sutil incremento de temperatura, o que sugere um caminho anti-horário (FIGURA 9).

Ambos os tipos de tendências, horária e anti-horária têm sido constatados em terrenos granulíticos. A trajetória em sentido horário, particularmente ITD, esta bem demonstrada. Por outro lado, a de sentido anti-horário, indicada pelo enriquecimento da componente grossulária 
na granada, pode não representar a verdadeira direção da trajetória P-T seguida pela rocha. No caso, a amostragem foi mais restrita para esta parte do orógeno, e além disso não há evidências texturais que confirmem a tendência. A possibilidade de que a trajetória do aumento da pressão possa ser causada por intercambio intercristalino entre granada e plagioclásio (conforme a SPEAR \& SELVERSTONE, 1983) é descartada, já que o aumento do Ca na granada acontece quando está em contato com biotita, não sendo possivel que ocorra reação com uma fase rica em cálcio. 


\section{METODOLOGIAS GEOCRONOLÓGICAS}

Em total foram feitas 105 análises geocronológicas, 50 análises U.Pb SHRIMP em zircão, 17 $\mathrm{Sm}-\mathrm{Nd}$ em rocha total e minerais, $20 \mathrm{Rb}-\mathrm{Sr}$ em rocha total e minerais, e $18 \mathrm{Ar}-\mathrm{Ar}$. As análises foram realizadas no Centro de Pesquisas Geocronológicas (CPGeo) do Instituto de Geociências da Universidade de São Paulo, exceto as análises U-Pb em zircão, que foram obtidas no SHRIMP II da Chinese Academy of Geological Sciences, em Beijing (China) por Liu Dunyi e Umberto Cordani. Os cálculos geocronológicos e a apresentação dos dados isotópicos foi feita através dos programas Isoplot e Squid 1.02 de LUDWIG $(1999,2001)$, utilizando, as constantes de desintegração recomendadas pela IUGS (STEIGER \& JÄGER, 1977).

\subsection{Análises U-Pb em zircão}

O urânio possui dois isótopos naturais, ${ }^{235} \mathrm{U}$ e ${ }^{238} \mathrm{U}$. Esses isótopos originam duas series de desintegração radioativa, tendo como produto final os isótopos radiogênicos estáveis de ${ }^{207} \mathrm{~Pb}$ $e^{206} \mathrm{~Pb}$ respectivamente $\left({ }^{235} \mathrm{U} \rightarrow{ }^{207} \mathrm{~Pb} \mathrm{e}^{238} \mathrm{U} \rightarrow{ }^{206} \mathrm{~Pb}\right)$. Do sistema geocronológico $\mathrm{U}-\mathrm{Pb}$ podemse obter três idades, dois de ${ }^{207} \mathrm{~Pb} /{ }^{235} \mathrm{U}$ e ${ }^{206} \mathrm{~Pb} /{ }^{238} \mathrm{U}$ (pais-filhos), e a outra idade conseguida da combinação, ${ }^{207} \mathrm{P} /{ }^{206} \mathrm{~Pb}$ (fitho-filho). Discussão adequada desta serie radioativa e do método de datação encontra-se em FAURE (1986) e DICKIN (1995).

O método de datação U-Pb em zircão é utilizado em rochas igneas para obter a idade da cristalização. Já em rochas metamórficas existem várias possíveis interpretações, posto que o zircão pode ser formado por processos de recristalização em estado sólido, processos subsolidus envolvendo fluido, ou em processos de cristalização após fusão parcial em rochas de alto grau. Nesses processos de fusão parcial o zircão pode participar em eventos de novo crescimento e/ou de dissolução das fases preexistentes, dependendo do teor de Zr presente no sistema (WATSON \& HARRISON, 1983). Em terrenos metamórficos de alto grau, o zircão pode-se formar por recristalização apenas parcial nas bordas de zircão igneo mais antigo, produto de cristalização magmática. Nestes casos é possivel observar zonação oscilatória que pode ser usada como testemunha de sua origem ígnea, e áreas recristalizadas sem zonação, indicando que estas porções externas do mineral foram formadas em condições sólidas (HOSKIN \& BLACK, 2000; NUTMAN, 2000).

O mineral incorpora $U$ em seu retículo durante a cristalização, e embora algum $\mathrm{Pb}$ radiogênico pode-se possa ser perdido durante metamorfismo, intemperismo ou lixiviação, sua idade de cristalização normalmente é possivel de determinação. 
Dessa forma, a sistemática U-Pb em zircão é considerada difícil de reajustar isotopicamente, até em condições de metamorfismo do fácies granulito, devido à alta temperatura do fechamento $\left(T_{f}\right)$ do sistema e a natureza refratária do zircão. Depois de sua cristalização, cristais de zircão podem permanecer estáveis na crosta durante processos de fusão e metamorfismo, que venham a ocorrer na evolução da rocha. Por este motivo, o método U-Pb em zircão é o mais confiável para determinar a idade do pico metamórfico, visto que a $T_{f}$ para este mineral é considerada $>800^{\circ} \mathrm{C}$.

O equipamento SHRIMP (Sensitive High Resolution Ion Microprobe) permite analisar diferentes áreas do zircão $(\sim 25 \mu \mathrm{m})$ pela incidência de um feixe de ions negativos de oxigênio que libera íons positivos na superfície polida do cristal. Os íons de $\mathrm{U}$ e $\mathrm{Pb}$ assim liberados são em seguida analisados em um espectrômetro de massa de alta resolução.

A vantagem desta técnica é que o sobrecrescimento ou recristalização em condições metamórficas podem ser datados ao lado de domínios correspondentes a zircão formado em ambiente magmático. As análises de zircão normalmente são acompanhadas de imagens de catodoluminiscência de luz transmitida para entender a sistemática de cristalização ou recristalização, par ter maior segurança que as idades obtidas refletem eventos magmáticos, metamórficos, anatexia ou possiveis heranças.

\subsubsection{Separação mineral e procedimento analítico}

A preparação da amostra e concentração dos zircões foi feita nos laboratórios de separação mineral do CPGeo segundo a seguinte rotina: fragmentação de amostras de 2 a $10 \mathrm{~kg}$, diminuição do tamanho dos grãos no britador de mandíbulas e moinho de disco, concentração da fração entre 100 e 250 mesh. O material coletado passa pela mesa gravitatória, pelo separador eletromagnético tipo Frantz, e pelos líquidos densos bromofórmio e iodeto de metileno, até a obtenção de um concentrado de zircões o mais puro possivel.

A montagem dos zircões em discos de resina epóxi foi feita no Laboratório da Academia Chinesa de Geociências, onde foram fotografados e analisados os zircões. As imagens de catodoluminiscência do ortognaisse $(\mathrm{V}-198)$ e o gnaisse granítico (A-746) foram obtidas posteriormente às análises isotópicas, no laboratório do $\mathrm{CPGeo}$, visto que os equipamentos da Academia Chinesa de Geociências não se encontravam funcionando.

Os erros analíticos do método U-Pb SHRIMP são expressos em $1 \sigma$. Os dados analíticos obtidos nesta pesquisa são plotados no diagrama de WETHERILL (1956), cuja curva 
Concórdia representa as razões ${ }^{206} \mathrm{~Pb} /{ }^{238} \mathrm{U}$ e ${ }^{207} \mathrm{~Pb} /{ }^{235} \mathrm{U}$ para todas as idades concordantes destes dois cronômetros. Na amostra Gr-29 optou-se também pelo diagrama TeráWasserburg, visto que a sistemática deste digrama permite visualizar melhor as trajetórias de perda de $\mathrm{Pb}$ recentes (NUTMAN, 2000). As idades aparentes ${ }^{207} \mathrm{~Pb} / 206 \mathrm{~Pb}$ são médias ponderadas de um grupo de dados concordantes (com $95 \%$ de nivel de confiança) e no caso da amostra V-198 correspondem a porções cristalinas dentro do zircão, corrigidas para $\mathrm{Pb}$ comum usando as medidas de ${ }^{204} \mathrm{~Pb}$.

De modo geral, em zircões velhos, pelas maiores quantidades de $\mathrm{Pb}$ radiogênico produzido, utilizam-se de preferência as idades aparentes ${ }^{207} \mathrm{~Pb} /{ }^{206} \mathrm{~Pb}$, visto que seus erros analiticos são menores comparados com aqueles gerados no cálculo das idades ${ }^{206} \mathrm{~Pb} /{ }^{238} \mathrm{U}$. Ao contrario, em zircões jovens, com menor produção de ${ }^{207} \mathrm{~Pb}$, são mais precisas as idades ${ }^{206} \mathrm{~Pb} / 238 \mathrm{U}$. Os termos velho e jovem são relativos, e no intervalo de tempo decorrido entre 1300 e $800 \mathrm{Ma}$, é difícil decidir qual idade aparente usar $\left({ }^{207} \mathrm{~Pb} /{ }^{206} \mathrm{~Pb}\right.$ ou $\left.{ }^{206} \mathrm{~Pb} /{ }^{238} \mathrm{U}\right)$ já que a decisão depende da concordância e do conteúdo de U no zircão (NUTMAN, 2000).

$\mathrm{Na}$ amostra A-746, com zircões mais jovens, foram utilizadas as idades aparentes ${ }^{206} \mathrm{~Pb} /{ }^{238} \mathrm{U}$ por serem mais precisas, mesmo tendo em conta seus erros de calibração de 1.5 a $2.5 \%$. Estas idades foram corrigidas para ${ }^{208} \mathrm{~Pb}$, e foram apresentadas no diagrama Tera-Wasserburg com proporções isotópicas totais.

Outro aspecto considerado foi o grau de discordância de cada idade aparente, que pode indica até que ponto o sistema permaneceu fechado. Nesta pesquisa considerou-se, no cálculo dos valores médios, as análises com porcentagem de discordância inferior a $5 \%$.

\subsection{Análises Sm-Nd}

$\mathrm{O}^{147} \mathrm{Sm}$ é um isótopo radioativo (pai) que desintegra-se no isótopo radiogênico ${ }^{143} \mathrm{Nd}$ (filho) com uma meia vida $T_{1 / 2}=$ Ga. A descrição completa do sistema isotópico e do método geocronológico Sm-Nd são encontradas em FAURE (1986), DICKIN (1995) e SATO et al. (1995).

$\mathrm{Sm}$ e $\mathrm{Nd}$ são elementos das terras raras (ETR), com comportamentos geoquímicos semelhantes. Estos elementos são encontrados em muitos minerais como substitutos de íns grandes. As proporções $\mathrm{Sm} / \mathrm{Nd}$ das rochas, no sistema rocha total, não se modificam significativamente por processos posteriores à sua formação, tais como hidrotermalismo ou intemperização (FAURE, 1986; DePAOLO, 1988). No momento de formação da rocha, e 
dependendo de sua aluminosidade, de modo geral, alguns minerais acessórios como monazita e allanita são ricos nas terras raras leves, e outros como zircão, xenotima e apatita nas pesadas (BEA, 1996). Dessa forma, quando a rocha é enriquecida nesses minerais e se a proporção deles foi modificada durante os processos evolutivos da rocha, pode ocorrer fracionamento de $\mathrm{Sm}$ e de $\mathrm{Nd}$, modificando substancialmente a razão inicial. Além disso, em alguns minerais, tais como (clinopiroxênio, anfibólio, apatita e granada) pode ocorrer certo fracionamento, com enriquecimento na razão $\mathrm{Sm} / \mathrm{Nd}$.

O sistema $\mathrm{Sm-Nd}$ é útil para determinar idades de cristalização de rochas igneas e metamórficas por meio de isócronas em rocha total, e idade da paragênese metamórfica por meio de isócrona rocha total-mineral desde que o processo metamórfico proporcione considerável fracionamento entre $\mathrm{Sm}$ e $\mathrm{Nd}$ (por ex. em RT-granada). A interpretação geológica de uma isócrona de dois pontos (rocha total-mineral) requer que a rocha total represente um sistema fechado, e que tenha sido o último reservatório com que o mineral equilibrou (MEZGER et al., 1992).

A temperatura de fechamento $\left(T_{f}\right)$ da granada no sistema isotópico Sm-Nd pode ser determinada empiricamente. Para a sua estimação é preciso comparar as idades da granada com idades obtidas de outros cronômetros com $\mathrm{T}_{\mathrm{f}}$ conhecidas, para a mesma unidade geológica, ou então determiná-la por geotermometria. $T_{f}$ de $600 \pm 30^{\circ} \mathrm{C}$ são reportadas por MEZGER et al. (1992) por meio da comparação do sistema Sm-Nd em granada com outros dados geocronológicos para terrenos metamórficos com exumação e resfriamento lentos.

A modificação mais significativa da razão $\mathrm{Sm} / \mathrm{Nd}$ em sistemas geológicos acontece durante o processo de diferenciação manto-crosta oceânica. A litosfera oceânica, no momento de formação, tem a mesma composição isotópica de Nd que o manto. Entretanto, por estar isolada quimicamente e por ter menor proporção $\mathrm{Sm} / \mathrm{Nd}$, sua composição de $\mathrm{Nd}$ evolui negativamente com respeito à do manto. Na crosta, os processos petrogenéticos (fusão parcial, metamorfismo, diagênese e alteração hidrotermal), a maioria da vezes não modificam a proporção $\mathrm{Sm} / \mathrm{Nd}$ adquirida na diferenciação inicial. Com esta premissa, pode-se fazer uma regressão das razões isotópicas atuais da rocha até interceptar a curva isotópica de Nd para o manto empobrecido (DM), e então estabelecer a idade modelo Sm-Nd T DM (SATO et al., 1995). A $T_{D M}$ pode representar o tempo em que uma rocha ou seu precursor separou-se do manto. Entretanto, segundo ARNDT \& GOLDSTEIN, 1987 para rochas formadas em processos de fusão parcial de sedimentos crustais mais antigos, o $T_{D M}$ representa um média ponderada das idades das diferentes fontes envolvidas. 
$O \epsilon_{\mathrm{Nd}}$ é um indicador petrogenético, obtido da comparação entre a razão ${ }^{143} \mathrm{Nd} /{ }^{144} \mathrm{Nd}$ da amostra para a época de sua formação com a razão de um reservatório condrítico uniforme padrão (CHUR) (FAURE, 1986). Este parâmetro permite diferenciar a derivação de fontes mantélicas ou crustais, sendo que material juvenil é sugerido por valores positivos ou levemente negativos de $\epsilon_{N d}$, e material retrabalhado (de origem sedimentar ou anatéctico) por valores altamente negativos de $\epsilon_{\mathrm{Nd}}$.

\subsubsection{Preparação das amostras e procedimento analítico}

Foram analisadas 10 amostras pelo método $\mathrm{Sm}-\mathrm{Nd}$ em rocha total e minerais (granada, plagioclásio, biotita e piroxênio) das unidades do Complexo Garzón.

A preparação e o tratamento analítico das amostras acham-se descritos em SATO et al. (1995) e SATO (1998), e incluem trituração e peneiramento, escolha criteriosa dos cristais de granada, piroxênio e biotita, ataque químico para dissolução do material, e separação dos elementos em coluna de troca iônica.

As razões isotópicas ${ }^{143} \mathrm{Nd} /{ }^{144} \mathrm{Nd}$ foram obtidas em espectrômetro de massa multi-coletor (VG 354) com precisão analítica de $0,014 \%(2 \sigma)$. Os erros máximos calculados para a razão ${ }^{147} \mathrm{Sm} /{ }^{144} \mathrm{Nd}$ são de $0,52 \%$. Brancos para o ataque químico durante as análises foram de 0,4 ng para Nd e 0,7 ng para Sm. Valores médios medidos no laboratório, no período em que as presentes análises foram efetuadas, para os padrões de $\mathrm{Nd}$ La Jolla e BCR-1 foram ${ }^{143} \mathrm{Nd} /{ }^{144} \mathrm{Nd}=0,511849 \pm 0,000025(1 \sigma)$ e $0,512662 \pm 0,000027(1 \sigma)$, respectivamente.

Os cálculos das idades modelo Sm-Nd $T_{D M}$ foram feitos de acordo com o modelo de estágio simples de DEPAOLO (1981), e para as amostras com $\mathrm{f}_{\mathrm{Sm} / \mathrm{Nd}}$ anômalos com o modelo de duplo-estágio de DEPAOLO et al. (1991). As constantes utilizadas no cálculo dos TDM e dos parâmetros $\epsilon_{\mathrm{Nd}}$, foram ${ }^{143} \mathrm{Nd} /{ }^{144} \mathrm{Nd}(\mathrm{CHUR})_{0}=0,512638$ e ${ }^{147} \mathrm{Sm} /{ }^{144} \mathrm{Nd}(\mathrm{CHUR})_{0}=0,1967$ (MICHARD et al., 1985).

\subsection{Análises $\mathrm{Rb}-\mathrm{Sr}$}

$O{ }^{87} \mathrm{Rb}$ é um isótopo radioativo (pai) que desintegra-se no isótopo radiogênico ${ }^{87} \mathrm{Sr}$ (filho) com meia vida $T_{1 / 2}=49 \mathrm{Ga}$. A sistemática $\mathrm{Rb}-\mathrm{Sr}$ e o método de datação isotópica estão detalhadamente expostos em FAURE, 1986, e DICKIN, 1995.

O Rb é um metal alcalino, e o $\mathrm{Sr}$ um metal alcalino-terroso. O primeiro substitui o $\mathrm{K}$ em micas, k-feldspatos, e minerais de argila, enquanto o segundo pode substituir o $\mathrm{Ca}$ em plagioclásio, 
apatita e carbonatos (FAURE \& POWELL, 1972). Este par de elementos tem comportamento geoquímico diferente, o $\mathrm{Sr}$ é relativamente imóvel em condições hidrotermais enquanto que o $\mathrm{Rb}$ é mais móvel, e dessa forma apresentem certo fracionamento nos processos de diferenciação manto-crosta. Durante a cristalização de magmas, o $\mathrm{Sr}$ concentra-se no plagioclásio, enquanto que o $\mathrm{Rb}$ permanece na fase liquida; conseqüentemente, a razão $\mathrm{Rb} / \mathrm{Sr}$ do magma residual aumenta gradualmente durante os processos progressivos de cristalização. Assim, quanto mais diferenciado é o material, maior é a razão $\mathrm{Rb} / \mathrm{Sr}$ (FAURE, 1986).

O sistema $\mathrm{Rb}-\mathrm{Sr}$ rocha total é um dos métodos isotópicos mais usados em rochas ácidas a intermédiarias, enriquecidas em $\mathrm{Rb}$ e/ou empobrecidas em $\mathrm{Sr}$, como também em minerais individuais. A pesar da ampla aplicabilidade, a geocronologia $\mathrm{Rb} / \mathrm{Sr}$ não é de fácil interpretação, visto que os dois elementos são móveis em muitos processos geológicos. sistema isotópico pode ser perturbado facilmente por influxo de fluidos ou por eventos termais tardios que favorecem a mobilidade do $\mathrm{Rb}$ e/ou $\mathrm{Sr}$, desta forma modificando as razões $\mathrm{Rb} / \mathrm{Sr}$ do sistema.

Por outro lado, se em amostras cogenéticas for obtido um alinhamento razoável em diagrama isocrónico, à linha de melhor ajuste pode atribuir-se a um evento geologicamente significativo tal como cristalização, metamorfismo ou alteração hidrotermal.

As idades isocrônicas minerais $\mathrm{Rb} / \mathrm{Sr}$ assumem uma condição de equilibrio isotópico, com total homogeneização isotópica dos minerais durante o metamorfismo (FAURE, 1986) e tem relação com uma temperatura característica, abaixo da qual o processo difusivo deixa de ser eficiente $e$, consequentemente, o decaimento radioativo (intragranular) evolui como num sistema fechado. De acordo com MUNHÁ \& TASSINARI (1999), para taxas de resfriamento moderadas $\left(10-30^{\circ} \mathrm{C} / \mathrm{Ma}\right)$ e granulação $\varphi=2 \mathrm{~mm}$, as $\mathrm{T}_{\mathrm{f}}(\mathrm{Sr})$ do $k$-feldspato, plagioclásio (albita) e apatita são de $500 \pm 50^{\circ} \mathrm{C}$, enquanto que para a biotita a $T_{f}(\mathrm{Sr})$ é de $350 \pm 50^{\circ} \mathrm{C}$. Para moscovita, apesar de não existirem dados experimentais, é geralmente aceita uma $\mathrm{T}_{\mathrm{f}}(\mathrm{Sr}) \sim$ $500^{\circ} \mathrm{C}$.

A razão $\mathrm{Rb} / \mathrm{Sr}$ aumenta com a diferenciação do material do manto para a crosta continental. Isto acarreta um aumento importante na razão inicial $\left({ }^{87} \mathrm{Sr} /{ }^{86} \mathrm{Sr}\right)_{\text {i }}$ em rochas com evolução crustal, se comparadas com os sistemas mantélicos.

$0{ }^{87} \mathrm{Sr}{ }^{86} \mathrm{Sr}$ inicial é indicador petrogenético importante, e identifica a participação de material juvenil (valores entre 0,699 e 0,703) ou de protolitos crustais (valores normalmente superiores 
a 0,705) (CORDANI et al., 2000). No intervalo entre 0,703 a 0,706 a procedência é incerta devido aos problemas de heterogeneidade do manto, como também no caso de mistura de materiais de fontes distintas, manto-crosta (SATO et al., 1995).

\subsubsection{Preparação das amostras e procedimento analítico}

Foram analisadas 18 amostras pelo método $\mathrm{Rb}-\mathrm{Sr}$ em rocha total e mineral (biotita e plagioclásio) das unidades do Complexo Garzón.

A preparação das amostras de rocha e mineral foi similar àquela das amostras analisadas pelo método $\mathrm{Sm} / \mathrm{Nd}$. O procedimento químico foi feito de acordo com as rotinas do laboratório do CPGeo, onde o branco laboratorial foi de $4 \mathrm{ng}$ de $\mathrm{Sr}$. As razões ${ }^{87} \mathrm{Sr} /{ }^{86} \mathrm{Sr}$ foram determinadas em espectrômetro de massa Isomass $354 \mathrm{com}$ um só coletor, tendo sido corrigidas para o valor médio do padrão NBS-987 $(0,710254 \pm 0.000022$ a $2 \sigma)$ e normalizadas $a{ }^{86} \mathrm{Sr} /{ }^{88} \mathrm{Sr}=$ 01194. A proporção ${ }^{87} \mathrm{Rb} /{ }^{86} \mathrm{Sr}$ foi obtida através de cálculos, a partir dos valores de $\mathrm{Rb}$ total $\mathrm{e}$ Sr total. Os teores de Rb-Sr das amostras Gr-15A, V-314, V-332, Gr-15, D-982, V-198, D-806$a, b$ foram determinados por fluorescência de Raio- $X$, com uma precisão de $\leq 1.4 \%$ para $R b$ e $\leq 1.0 \%$ para Sr. Já as concentrações Rb-Sr das amostras Gr-29, Gr-29 a,b,d,e,f,h,i, V-290 e D 806-c foram obtidas por diluição isotópica, com precisão superior.

\subsection{Análises Ar-Ar}

O método ${ }^{40} \mathrm{Ar}-{ }^{39} \mathrm{Ar}$, cujos fundamentos apojam-se no método $\mathrm{K}-\mathrm{Ar}$, fol empregado em anfibólios e biotitas separados das rochas regionais do Complexo Garzón. A preparação das amostras e os procedimentos de rotina efetuados no CPGeo, para este método, estão incluidos em VASCONCELOS et al. (2002).

Os grãos dos minerais selecionados foram montados em discos de aluminio para irradiação no reator nuclear tipo IEA-R1 no IPEN em São Paulo, cujo fluxo integrado é de $10^{16}-10^{18}$ nêutrons rápidos $/ \mathrm{cm}^{2}$ durante um período longo de irradiação (duas semanas). O material foi irradiado conjuntamente com amostras padrão de idade Ar/Ar bem conhecida, estrategicamente localizadas no mesmo recipiente. Após a irradiação, dois ou três grãos de cada amostra foram montados num porta-amostras de cobre, e a extração do gás foi realizada em espectrômetro de massa de alta sensibilidade MAP-215-50, acoplado a um sistema de ultra-alto vácuo com feixe de raios laser.

As análises foram efetuadas pelo método de fusão por etapas, em que varias idades aparentes (normalmente entre 5 e 10) são determinadas para cada amostra. 
$\mathrm{Na}$ interpretação de datacões ${ }^{40} \mathrm{Ar}-{ }^{39} \mathrm{Ar}$ normalmente utiliza-se a idade plateau, que corresponde a um patamar atingido por várias idades concordantes, relativas a diferentes frações do gás liberado, as quais juntas representam mais do que $50 \%$ de ${ }^{39} \mathrm{Ar}$ liberado da amostra, sem diferenças na idade aparente que possam ser detectadas a um nível de $2 \sigma$ (Fleck et al., 1977 apud McDOUGALL \& HARRISON, 1999).

Alternativamente, neste método de datação pode utilizar-se a idade integrada que utiliza a quantidade total de argônio liberado na análise, e sua interpretação é similar à do método K-Ar. Por outro lado, uma idade Ideograma corresponde a um diagrama dos picos de probabilidade estatística para a amostra em questão. Nos casos de amostras com história térmica bem definida, os três tipos de idades (plateau, integrada, ideograma) são concordantes dentro do êrro experimental.

As idades obtidas em biotita, nos casos de rochas igneas resfriadas lentamente, e de rochas metamórficas, refletem a época do abaixamento da temperatura sob $300-350^{\circ} \mathrm{C}$. No caso de hornblenda, mineral muito retentivo para argônio radiogênico, a idade reflete normalmente o resfriamento abaixo de $T_{f} \sim 500^{\circ} \mathrm{C}$ (MCDOUGALL \& HARRISON, 1999). 


\section{INTERPRETAÇÃO DOS DADOS GEOCRONOLÓGICOS}

A geocronologia é aplicada a diversas rochas do Maciço de Garzón com o propósito de obter informação dos eventos geológicos que atuaram na sua evolução. Com a interpretação conjunta das idades, da temperatura de fechamento $\left(T_{f}\right)$ dos minerais, e da temperatura máxima atingida pelo metamorfismo, é possivel determinar aproximadamente as épocas do seu pico metamórfico ou do metamorfismo retrogressivo. De esta forma, pode-se construir a trajetória P-T-t do metamorfismo com a combinação dos dados de idade, temperatura, pressão e evidência textural. Alem disso, pode-se obter informação da história do resfriamento, acompanhando a exumação.

Com a utilização da termocronologia em rochas metamórficas, podem ser obtidas diferentes idades de sistemas geocronológicos com caracteristicas cinéticas distintas (MUNHÁ \& TASSINARI, 1999). Tais idades refletem as várias temperaturas de fechamento $\left(\mathrm{T}_{f}\right)$ de DODSON (1973), ou seja, aquela temperatura limite abaixo da qual a difusão deixa de ser eficiente $e$, conseqüentemente, o decaimento radioativo (intragranular) evolui como num sistema fechado. Entretanto, em rochas metamórficas, a presença de fluidos a baixa temperatura, associados a fases de deformação, podem afetar a $T_{f}$ e apagar o sistema isotópico inicial (VILLA, 1998), sendo que para cada sistema geocronológico a Tié variável, e depende dos coeficientes de difusão iônica dos elementos, taxa de resfriamento, granulação efetiva, bem como do modelo de difusão adotado (SPEAR, 1991).

Por meio da geoquimica isotópica ( $\mathrm{Sr}$ e $\mathrm{Nd}$ ) pretende-se indagar a respeito dos processos que contribuíram na formação do orógeno. Ora distinguir assinaturas juvenís ou processos de contaminação crustal em rochas magmáticas, ora fornecer idades médias de residência crustal para rochas de origem sedimentar ou vulcânico.

Os dados geocronológicos obtidos serão apresentados em seqüência, de acordo com cada metodología empregada. A descrição petrográfica das amostras empregadas para datação está compilada no ANEXO $V$ e a localização das mesmas aparece no ANEXO I.

\subsection{Datações U-Pb em zircão}

As análises isotópicas foram realizadas em zircões de três amostras das unidades do Complexo Garzón: Gnaisse de Guapotón-Mancagua (V-198), Granulitos do Vergel (Gr-29), e Gnaisse das Margaritas ( $\mathrm{Gr}-15 \mathrm{~A}$ ). Adicionalmente foi analisado um granodiorito gnáissico da Cocha Rio Tellez (A-746), localizado ao sudeste do Maciço de Garzón. 
Os resultados $\mathrm{U}-\mathrm{Pb}$ SHRIMP para todas as amostras são apresentados sucintamente na TABELA 1 e de forma completa no ANEXO VI.

A FIGURA 24 é um diagrama Concórdia que inclui os pontos analíticos de um ortognaisse (V198) do Gnaisse de Guapotón-Mancagua. Os zircões desta amostra são rosa pálido, com formas alongadas, arredondados e multifacetados, e proporções comprimento/largura 3:1. As imagens de catodoluminiscência mostram núcleos com fraca zonação oscilatória, o qual sugere crescimento magmático, e sobrecrescimentos de moderada a baixa luminosidade, de origem metamórfica (FIGURA 25). As doze análises realizadas em 11 zircões podem ser agrupadas em duas populações. A primeira, definida por três dados concordantes (análises 5 , 6 e 11 dos núcleos), fornece uma idade média de $1148 \pm 69$ (MSWD $=2,3$ ). Os quatro outros dados concordantes (análises 2,7,10,12 das bordas) representam a segunda população, com idade média de $1005 \pm 26$ (MSWD = 0,7). As proporções $T h / U$ dos zircões änalisados estão entre 0,21-0,46, típicas de zircões ígneos e metamórficos de alto grau (VABRA et al., 1999). Descartaram-se no cálculo de idade as análises discordantes com respeito à concórdia (1,3,4,8 e 9), e/ou com grandes erros analíticos. A idade mais antiga se interpreta como o tempo de cristalização de um precursor granítico, e a mais jovem reflete o metamorfismo superimposto sobre o precursor, na transição entre as fácies anfibolito-granulito. A interpretação é feita com base nas imagens de catodoluminiscência, e de acordo com os dados geoquímicos de KROONENBERG (2001) e RESTREPO-PACE (1995) que indicam um ambiente cálcio-alcalino para a seqüência de rochas do maciço, e sugerem uma fase de magmatismo antes da colisão final. A idade de intrusão do batolito de $1148 \pm 69 \mathrm{Ma}$, levando em conta o erro, se sobrepõe ao valor de $1098 \pm 9$ Ma reportado por RESTREPO-PACE et al. (1997) dos zircões analisados pelo método U-Pb convencional.

Na FIGURA 26 estão os dados analíticos dos zircões do granulito de composição enderbítica (Gr-29) pertencente aos Granulitos do Vergel. Duas populações são identificadas com base na morfologia, uma de zircões arredondados castanho escuros com proporções comprimento/largura de $2: 1$, e outra de zircões mais alongados. Os zircões são altamente metamictos, com altos conteúdos de $\mathrm{U}$, o que facilita perdas de $\mathrm{Pb}$ pela maior destruição do retículo cristalino. As idades são discordantes, contudo podem-se determinar três tendências diferentes. Duas análises discordantes $(8,12)$ indicam a presença de componentes $>1300 \mathrm{Ma}$, três análises $(1,3,14)$ definem um arranjo que corta a concórdia ao redor de $1100 \mathrm{Ma}$ com intercepto inferior a $400 \mathrm{Ma}$, e outras três análises de zircões arredondados $(2,4, e$ 13) também sugerem um grupo por volta de $1000 \mathrm{Ma}$. No diagrama de TERA \& WASSERBURG (1972) (FIGURA 27) verifica-se que as demais análises $(5,6,7,9,10,11)$, que têm os maiores conteúdos de $\mathrm{U}$, 
TABELA 1. Idades U-Pb SHRIMP em zircão de amostras do Maciço de Garzón e Complexo Migmatítico da Cocha Rio Tellez

\begin{tabular}{|c|c|c|c|c|c|c|c|c|c|}
\hline \multirow[t]{2}{*}{ Rocha } & \multirow[t]{2}{*}{ Análise } & \multirow[t]{2}{*}{ Hábito } & \multirow{2}{*}{$\frac{U}{(\mathrm{ppm})}$} & \multirow{2}{*}{$\frac{\mathrm{Pb}}{(\mathrm{ppm})}$} & \multicolumn{5}{|c|}{ Idades $(M 0)$} \\
\hline & & & & & ${ }^{206} \mathrm{~Pb} /{ }^{238} \mathrm{U}$ & \pm & ${ }^{207} \mathrm{~Pb} /{ }^{206} \mathrm{~Pb}$ & \pm & $\%$ Disc. \\
\hline \multicolumn{10}{|l|}{ Ortognaisse bt-hbl } \\
\hline \multirow{12}{*}{$V-198$} & 1 & $f$ & 38 & 6,0 & 1073 & 23 & 743 & 220 & -44 \\
\hline & 2 & $p, b, h$ & 338 & 49,1 & 1007 & 18 & 996 & 27 & -1 \\
\hline & 3 & $\mathrm{p}, \mathrm{m}$ & 174 & 30,7 & 1200 & 20 & 1067 & 42 & -12 \\
\hline & 4 & $p, m, o s c$ & 99 & 15,8 & 1098 & 21 & 1255 & 48 & 12 \\
\hline & 5 & $p, n$ & 227 & 38,7 & 1165 & 19 & 1118 & 30 & -4 \\
\hline & 6 & $f, n, o s c$ & 387 & 64,4 & $114 i$ & 18 & 1183 & 20 & 4 \\
\hline & 7 & $f, b$ & 80 & 11,8 & 1014 & 18 & 1019 & 93 & 1 \\
\hline & 8 & $f, h$ & 319 & 52,0 & 1111 & 18 & 918 & 130 & -21 \\
\hline & 9 & $p$ & 197 & 28,9 & 1012 & 18 & 946 & 44 & .7 \\
\hline & 10 & b & 495 & 74,9 & 1045 & 16 & 1020 & 19 & -2 \\
\hline & 11 & $f, n$ & 202 & 34,7 & 1175 & 23 & 1132 & 22 & -4 \\
\hline & 12 & $p, b$ & 411 & 61,0 & 1025 & 16 & 984 & 26 & -4 \\
\hline \multicolumn{10}{|l|}{ Granulito opx-cpx } \\
\hline \multirow{14}{*}{ Gr-29 } & 1 & $\mathrm{i}$ & 1066 & 162 & 1050 & 12 & 1091 & 8.9 & 4 \\
\hline & 2 & $\mathrm{i}$ & 1214 & 162 & 932 & 11 & 1017 & 9.1 & 8 \\
\hline & 3 & $\mathrm{i}$ & 1312 & 203 & 1066 & 13 & 1106 & 7.5 & 4 \\
\hline & 4 & $\mathrm{i}$ & 877 & 113 & 897 & 11 & 1000 & 13 & 10 \\
\hline & 5 & $\mathrm{i}$ & 1280 & 165 & 899 & 12 & 1361 & 13 & 34 \\
\hline & 6 & $i$ & 1611 & 154 & 679 & 9.2 & 1178 & 41 & 42 \\
\hline & 7 & $\mathrm{i}$ & 1500 & 162 & 759 & 9.3 & 1390 & 93 & 45 \\
\hline & 8 & $\mathrm{i}$ & 898 & 175 & 1320 & 15 & 1402 & 6.8 & 6 \\
\hline & 9 & $\mathrm{i}$ & 1256 & 180 & 995 & 15 & 1089 & 11 & 9 \\
\hline & 10 & $\mathrm{i}$ & 869 & 92.6 & 753 & 9.2 & 1160 & 12 & 35 \\
\hline & 11 & $\mathrm{i}$ & 564 & 74.2 & 912 & 11 & 1160 & 59 & 21 \\
\hline & 12 & $i$ & 634 & 119 & 1276 & 15 & 1423 & 9.6 & 10 \\
\hline & 13 & i & 745 & 96.8 & 908 & 11 & 1035 & 11 & 12 \\
\hline & 14 & $i$ & 1077 & 172 & 1097 & 16 & 1139 & 12 & 4 \\
\hline \multicolumn{10}{|l|}{ Gnaisse $q t z-k f d-b t$} \\
\hline \multirow{12}{*}{ Gr-15 } & 1 & $f$ & 431 & 60.4 & 973 & 22 & 998 & 17 & 2 \\
\hline & 2 & $f$ & 655 & 92.5 & 981 & 22 & 1005 & 14 & 2 \\
\hline & 3 & $f$ & 637 & 90.0 & 981 & 12 & 1028 & 11 & 5 \\
\hline & 4 & $p$ & 470 & 66.5 & 983 & 12 & 1006 & 14 & 2 \\
\hline & 5 & $p$ & 897 & 127 & 985 & 17 & 1024 & 9,8 & 4 \\
\hline & 6 & $p$ & 429 & 61.1 & 988 & 12 & 1036 & 13 & 5 \\
\hline & 7 & $p$ & 484 & 67.5 & 970 & 16 & 1006 & 15 & 4 \\
\hline & 8 & $f$ & 415 & 58.2 & 973 & 12 & 999 & 15 & 3 \\
\hline & 9 & $p$ & 264 & 37.2 & 980 & 12 & 1034 & 18 & 5 \\
\hline & 10 & $p$ & 460 & 66.1 & 997 & 12 & 1017 & 14 & 2 \\
\hline & 11 & $f$ & 377 & 53.2 & 978 & 12 & 1003 & 17 & 2 \\
\hline & 12 & $p$ & 447 & 64.2 & 996 & 12 & 1002 & 15 & 1 \\
\hline \multirow[t]{13}{*}{ Granodiorito gnaiss. } & & & & & * & & & & \\
\hline & 1 & $p$ & 39 & 0,9 & 165 & 6.8 & ----- & $\cdots \cdots$ & $\cdots$ \\
\hline & 2 & $p$ & 164 & 3,7 & 164.9 & 6.6 & ------ & $\cdots$ & $\cdots$ \\
\hline & 3 & $p$ & 24 & 0,6 & 173 & 8.7 & -..--- & -- & $\cdots$ \\
\hline & 4 & $p$ & 325 & 7,5 & 168 & 6.4 & ------- & $\cdots$ & -- \\
\hline & 5 & $p$ & 62 & 1,4 & 156 & 6.3 & $\ldots$ & --- & $\cdots$ \\
\hline & 6 & coberto & 65 & 1,6 & 175 & 6.5 & $+\cdots+\infty+\infty$ & $\ldots$ & --- \\
\hline & 7 & $p$ & 57 & 1,4 & 172 & 6.4 & .......... & --- & $\cdots$ \\
\hline & 8 & $p$ & 33 & 0,8 & 162 & 11 & --.-.-- & --- & $-\cdots$ \\
\hline & 9 & $p$ & 53 & 1,2 & 161 & 6.7 & -......- & -- & --- \\
\hline & 10 & $p$ & 62 & 1,5 & 173 & 6.4 & -.....- & -- & $\cdots$ \\
\hline & 11 & $\mathrm{p}$ & 61 & 1,3 & 159 & 6.0 & גב...... & --- & $\cdots$ \\
\hline & 12 & $f$ & 164 & 3,8 & 166 & 6.4 & $\ldots . . . \cdots \cdot$ & $\ldots$ & -- \\
\hline
\end{tabular}

Hábitos: $p=$ prismático, i=isométrico, f=fragmento

Sitio da análises: $b=b o r d a, ~ n=$ núcleo, $m=$ intermediario

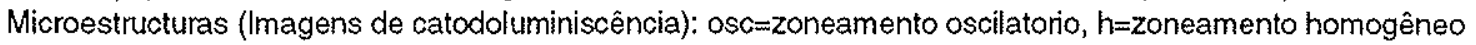

* = Idades obtidas com razões corregidas para $\mathrm{Pb} \mathrm{cm}$ assumindo idade concordante $206 \mathrm{~Pb} / 238 \mathrm{U}-208 \mathrm{~Pb} / 232 \mathrm{Th}$ 


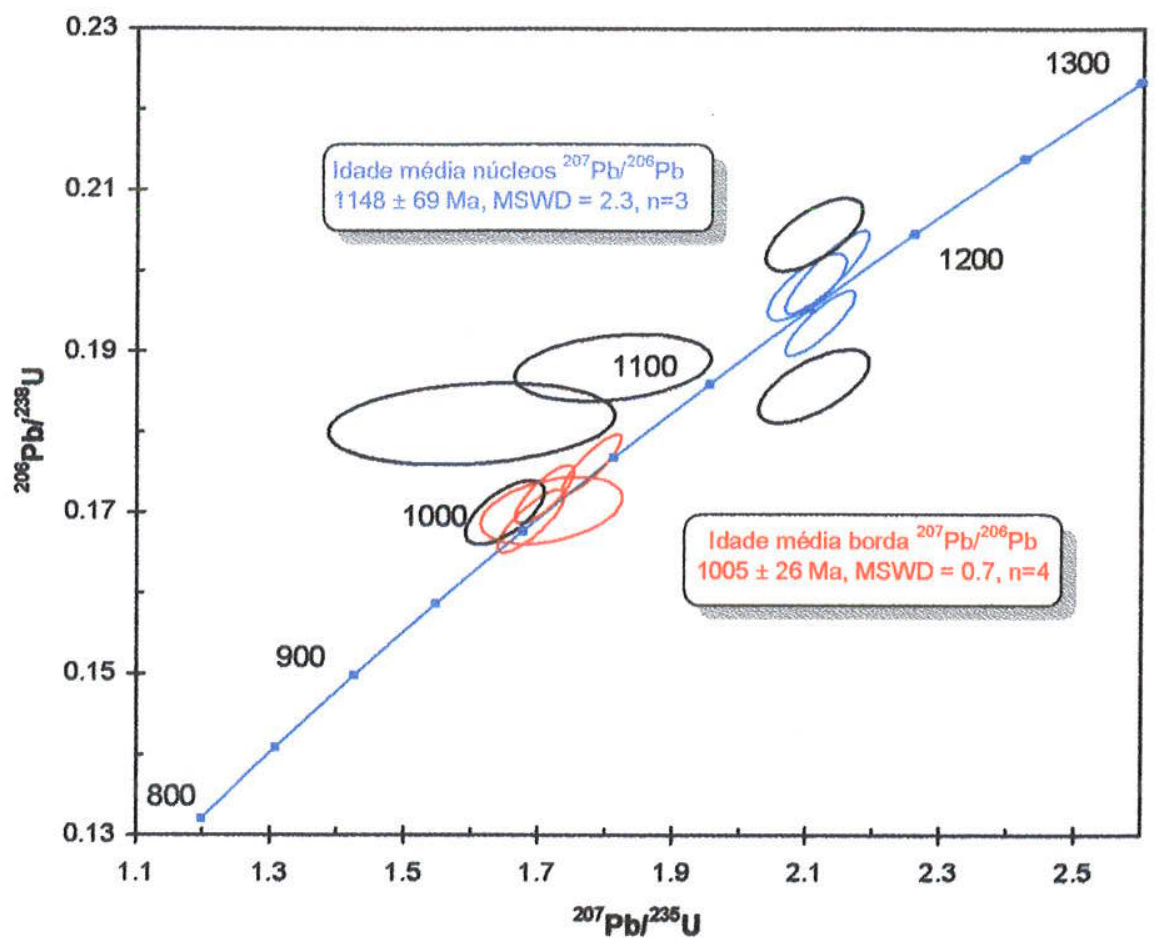

FIGURA 24 - Diagrama Concórdia do ortognaisse V-198.
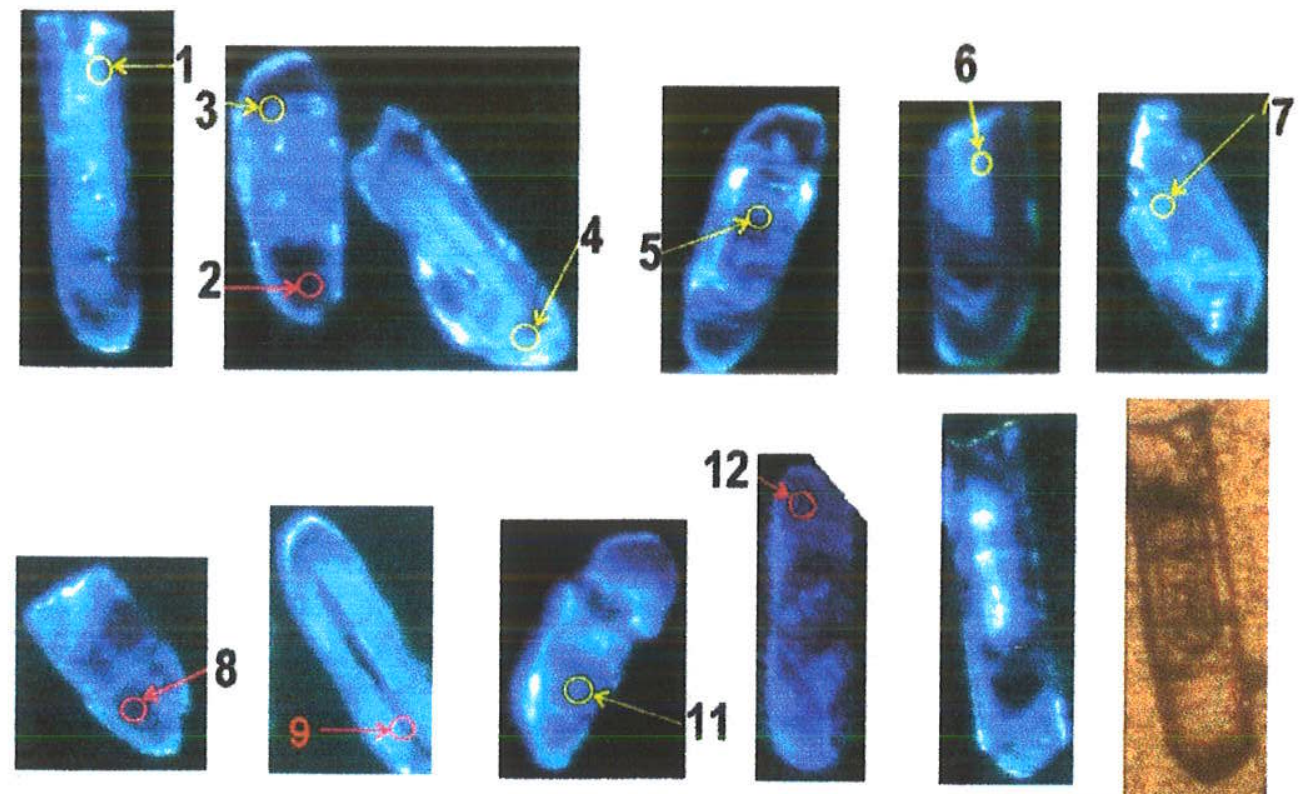

$0.536 \mathrm{~mm}$

FIGURA 25 - Imagens de catodoluminiscência do ortognaisse V-198, análises de núcleo em amarelo e de bordas em vermelho. 


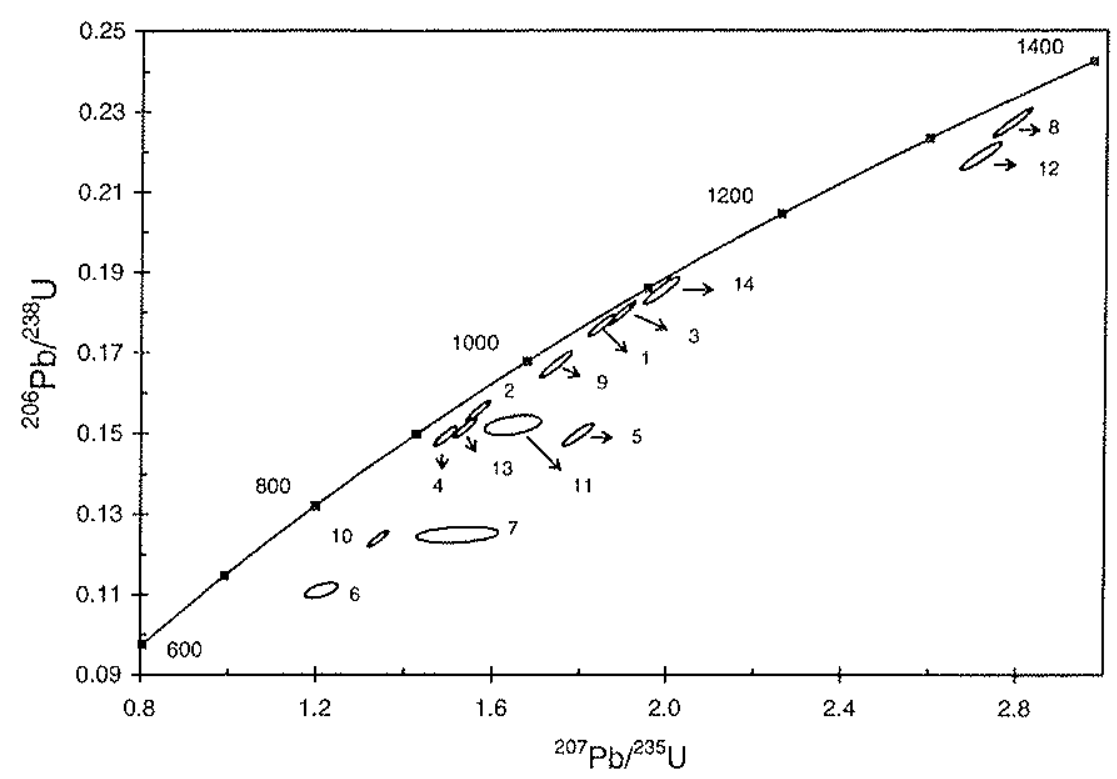

FIGURA 26 - Diagrama Concórdia do granulito enderbítico Gr-29.

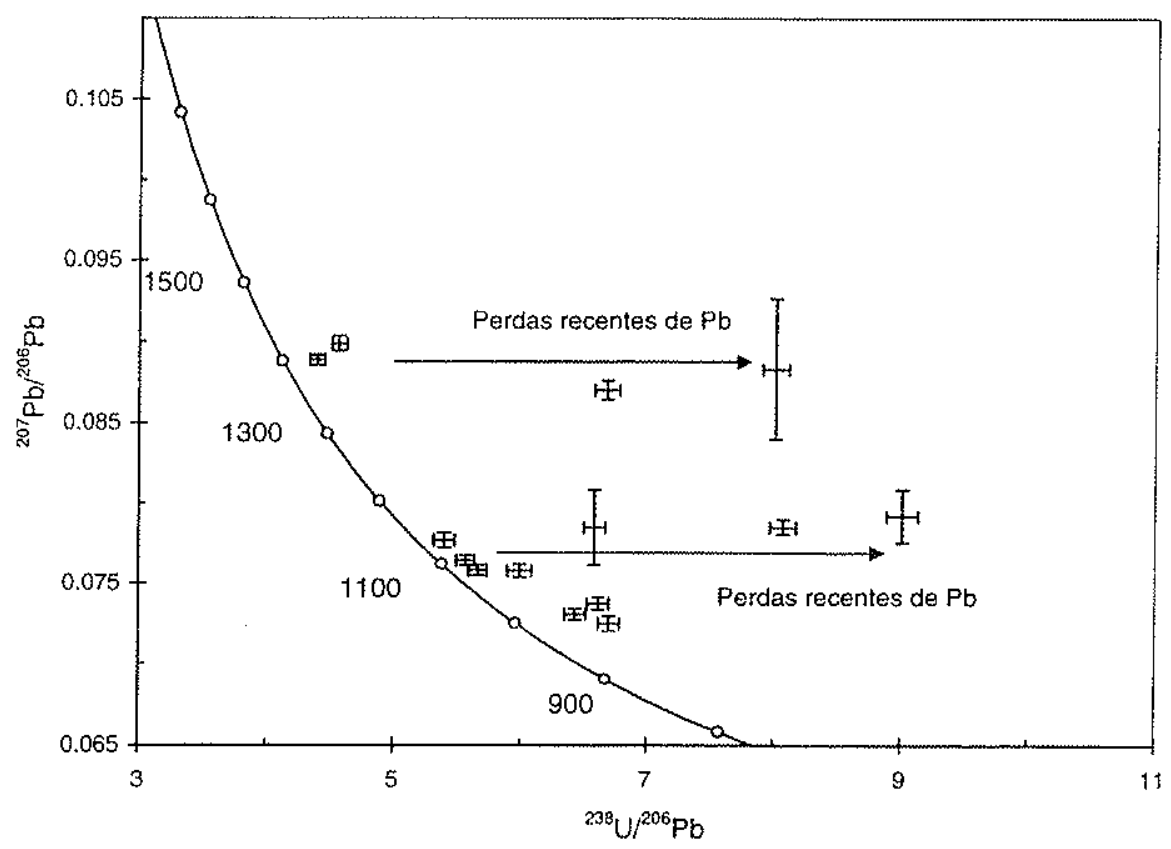

FIGURA 27 - Diagrama Tera-Wasserburg do granulito enderbítico Gr-29.

sugerem perdas recentes de $\mathrm{Pb}$, evidenciadas pelo deslocamento em sentido linear ao interior do diagrama (NUTMAN, 2000). A metamictização aconteceu em condições de temperatura $<300^{\circ} \mathrm{C}$ visto que a idade Ar-Ar na biotita de 914 Ma da mesma amostra (FIGURA 43) não foi rejuvenescida. As formas arredondadas dos grãos, a variedade de tamanhos e as tendências 
diferentes na idade indicam a origem detrítica dos zircões. Neste sentido os valores de $\sim 1100$ e 1400 Ma representem fontes com idades mínimas mesoproterozóicas, e o valor próximo de $\sim 1000 \mathrm{Ma}$ representa um evento metamórfico, apoiado na isócrona mineral Sm-Nd de $929 \pm$ $32 \mathrm{Ma}$, e também na idade Ar-Ar mencionada em biotita do granulito.

A FIGURA 28 é o diagrama Concórdia para o granito-gnaisse (leucossoma 2 de injeção, amostra Gr-15-a) do Gnaisse das Margaritas. Os zircões são prismas rosados, biterminados e com faces bem formadas. Das doze análises, nove dados $(1,2,4,5,7,8,10,11,12)$ são concordantes e definem uma idade média de $1006 \pm 6.4 \mathrm{Ma}$ (MSWD =0.51), a qual representa a idade de cristalização magmática para esta amostra.

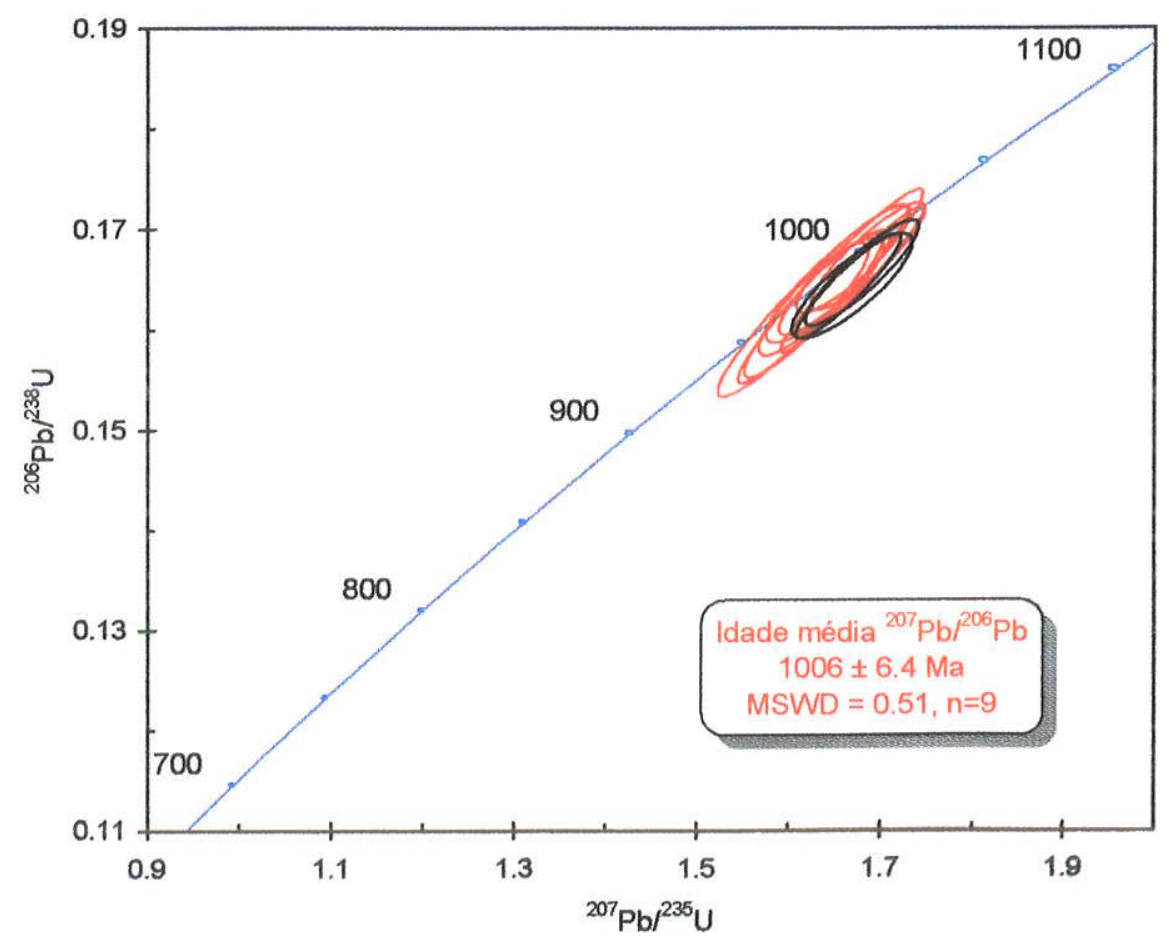

FIGURA 28 - Diagrama Concórdia do quartzo-feldspato-biotita gnaisse (leucossoma 2 de injeção, amostra Gr-15a). 


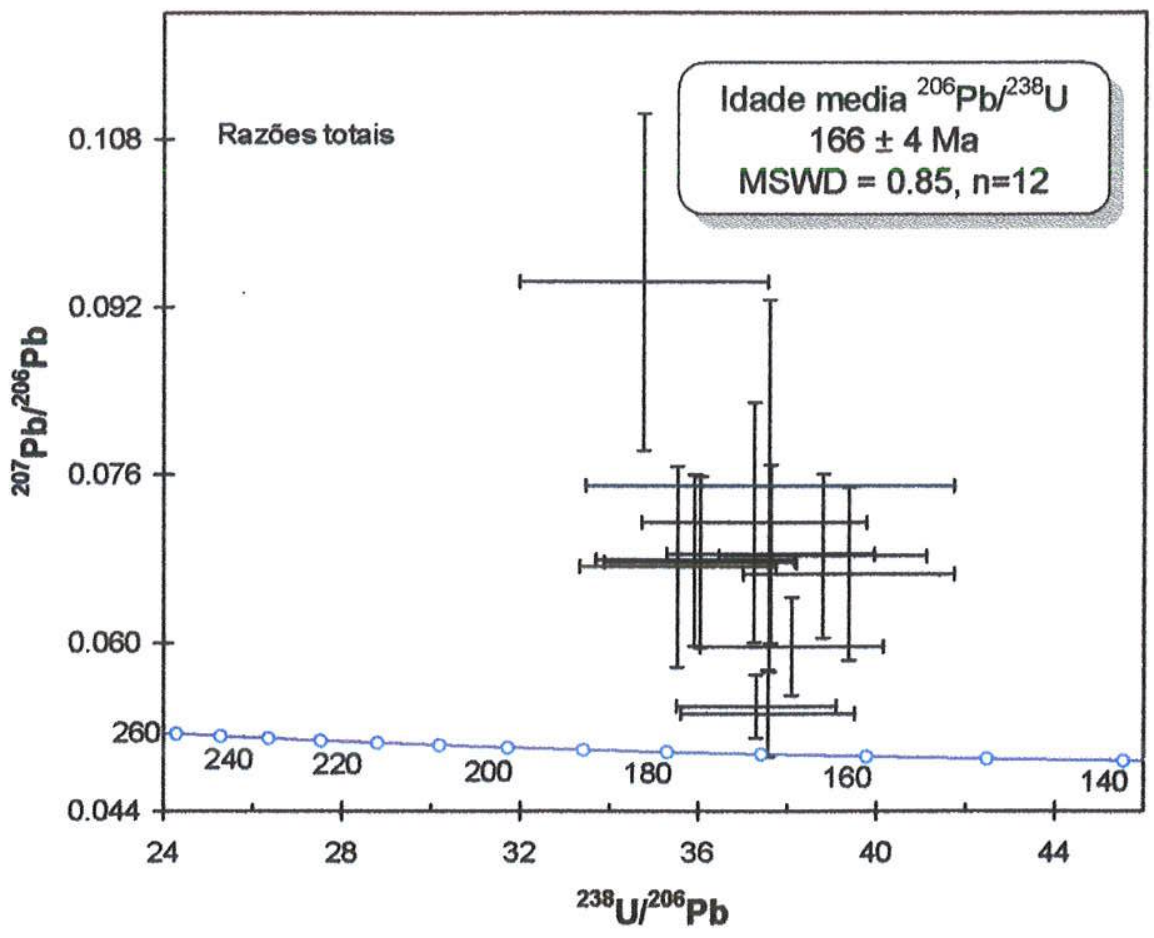

FIGURA 29 - Diagrama Tera-Wasserburg do granodiorito gnáissico A-746
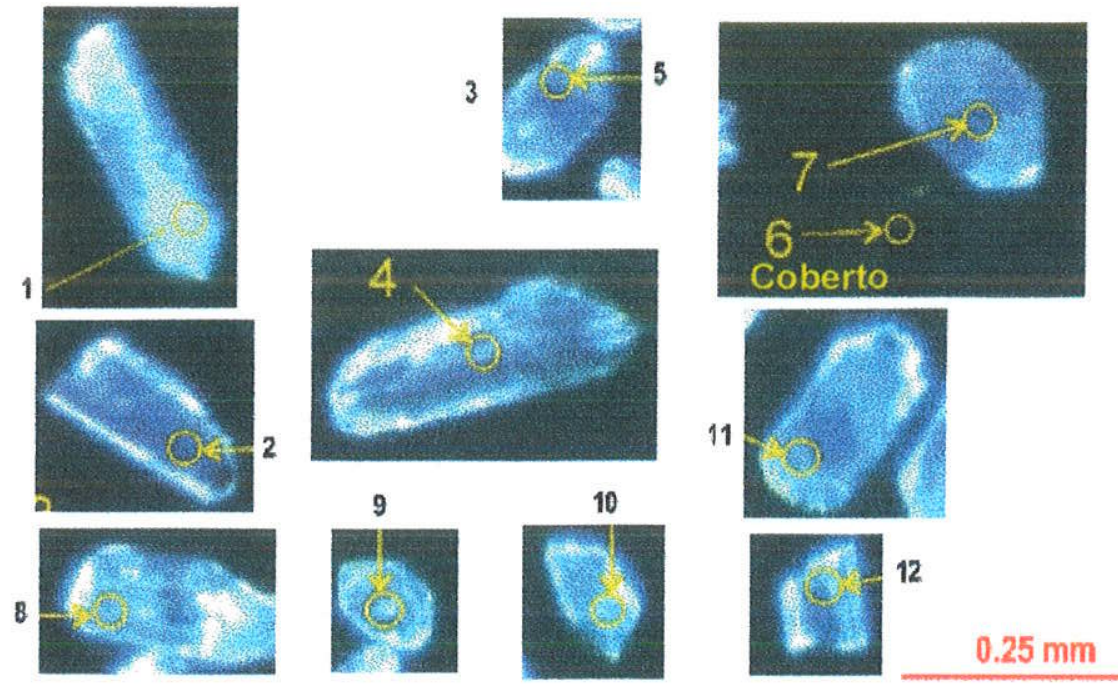

FIGURA 30 - Imagens de catodoluminescência do granodiorito gnáissico A-746 
de 1,5:1 a 3:1, rosa translúcidos, com faces bem definidas e terminações bipiramidadas. Os doze dados analíticos definem uma idade média de $166 \pm 4 \mathrm{Ma}$ (MSWD $=0.85$ ), interpretada como a época de colocação do ortognaisse. Nestes zircões a produção de ${ }^{207} \mathrm{~Pb}$ foi baixa, e as razões medidas ${ }^{207} \mathrm{~Pb} /{ }^{206} \mathrm{~Pb}$ apresentam pouca precisão, originando razões ${ }^{207} \mathrm{~Pb} /{ }^{235} \mathrm{U}$ com erros muito altos, de modo que as razões radiogênicas das análises $(1,3,5,6,7,8,9)$ não são calculadas pelo programa Squid 1.02 de LUDWIG (2001) (ANEXO VI).

\subsection{Sistemática Sm-Nd}

Os resultados isotópicos das análises $\mathrm{Sm}-\mathrm{Nd}$ em rocha total (RT) e mineral são listados na TABELA 2. Os gráficos das figuras 31 a 34 representam as interpretações escolhidas para este trabalho, e incluem:

- quatro isócronas em RT e granada das amostras V-332 e D-982 dos Granulitos do Vergel, e C-32 e Gr-15 p do Gnaisse das Margaritas.

- uma isócrona mineral com plagioclásio, piroxênio e a rocha total da amostra Gr-29 dos Granulitos do Vergel.

- dez idades TDM das amostras: V-198 do Gnaisse de Guapotón-Mancagua, D-982,V-332,V314,Gr-29,Gr-29b,Gr-29d dos Granulitos do Vergel, e C-32,Gr-15p,Gr-15-A do Gnaisse das Margaritas.

Granadas separadas do granulito charnockítico (V-332) e do gnaisse quartzo-feldspático (D982), que fazem parte dos Granulitos do Vergel, fornecem idades Sm-Nd em RT-granada de $935 \pm 5$ e $925 \pm 7 \mathrm{Ma}$, respectivamente (FIGURA 31). Os valores das idades aparentes para estas duas rochas são similares dentro dos erros experimentais. As idades $S \mathrm{~m} / \mathrm{Nd} \mathrm{RT}$ granada de um gnaisse biotítico com granada (Gr-15p) e um granulito com ortopiroxêniogranada-hornblenda (C-32), do Gnaisse das Margaritas, são mais antigas, com valores de $1034 \pm 6$ e $991 \pm 8 \mathrm{Ma}$, respectivamente (FIGURA 32).

As idades de $~ 930 \mathrm{Ma}$ dos Granulitos do Vergel são significativamente mais jovens do que o metamorfismo de - $1000 \mathrm{Ma} \mathrm{U-Pb}$ SHRIMP em zircão reportado no granulito Gr-29. Dessa forma, são interpretadas como idades de resfriamento deste evento abaixo de $600^{\circ} \mathrm{C}$, considerando-se o valor de $T_{f}$ da granada (MEZGER et al., 1992).

As idades Sm-Nd em RT-granada por volta de 1034 e 990 Ma do Gnaisse das Margaritas interpretam-se como a época do resfriamento do evento metamórfico prógrado de alto grau. $\mathrm{A}$ primeira idade, do gnaisse biotítico Gr-15p, representa o resfriamento abaixo da $T_{f}$ de $600^{\circ} \mathrm{C}$ de MEZGER et al. (1992). A segunda idade, do granulito máfico C-32 é mais jovem, e pode 
TABELA 2 - Análises Sm-Nd em rocha total e mineral das amostras do Maciço Garzón

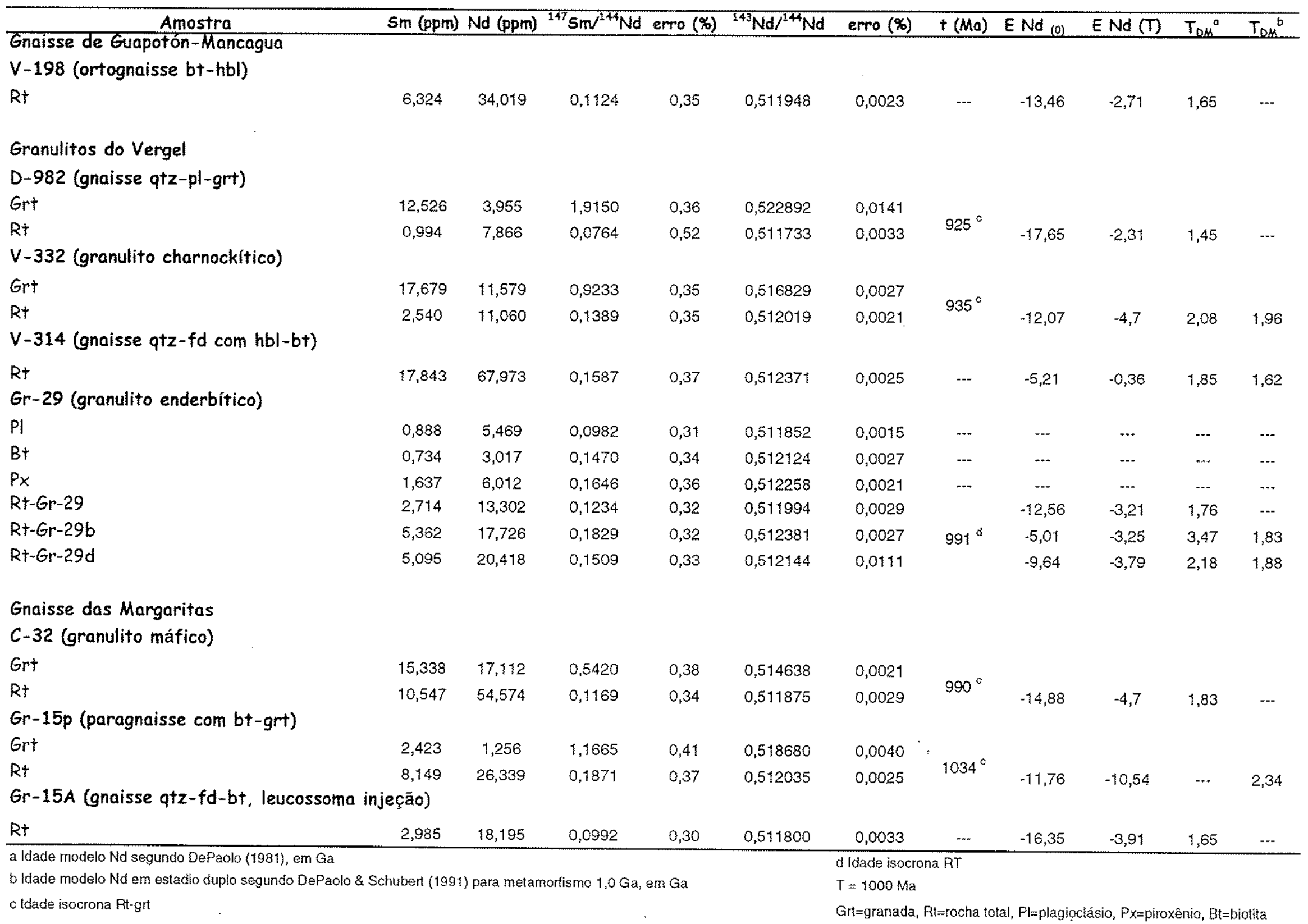




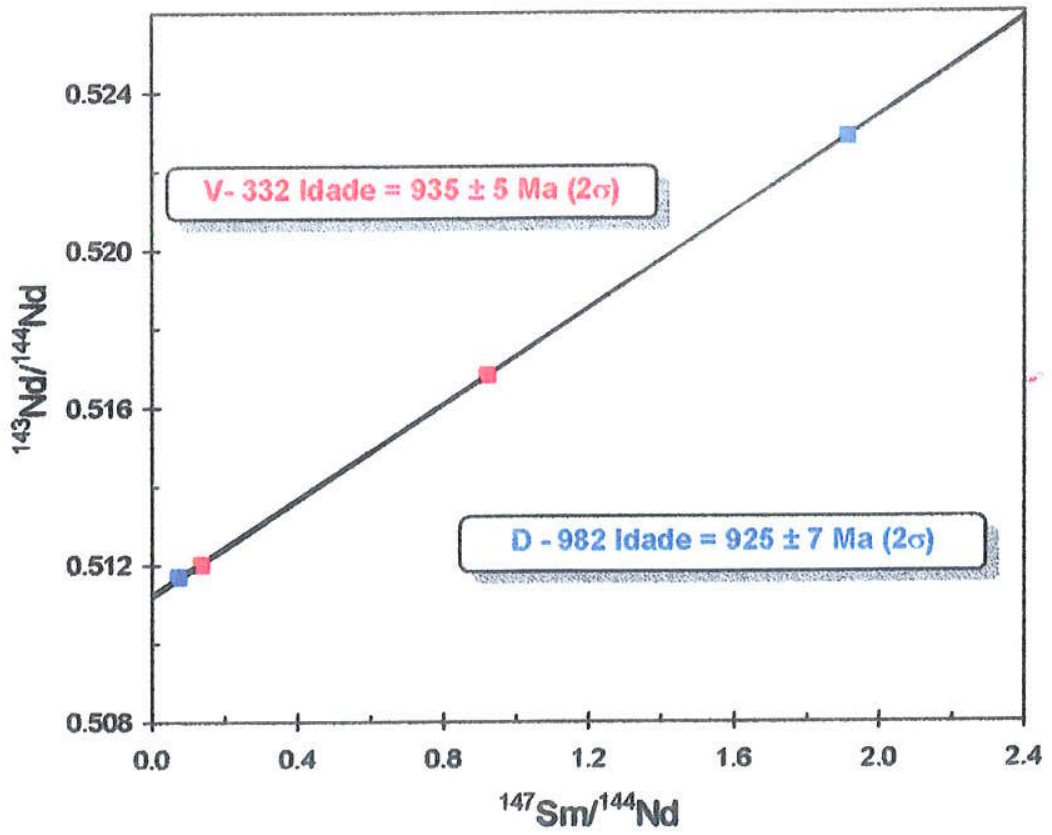

FIGURA 31 - Isócronas Sm-Nd em rocha total e granada do granulito charnockítico V-332 e do quartzo-feldspato gnaisse D- 982, pertencentes aos Granulitos do Vergel.

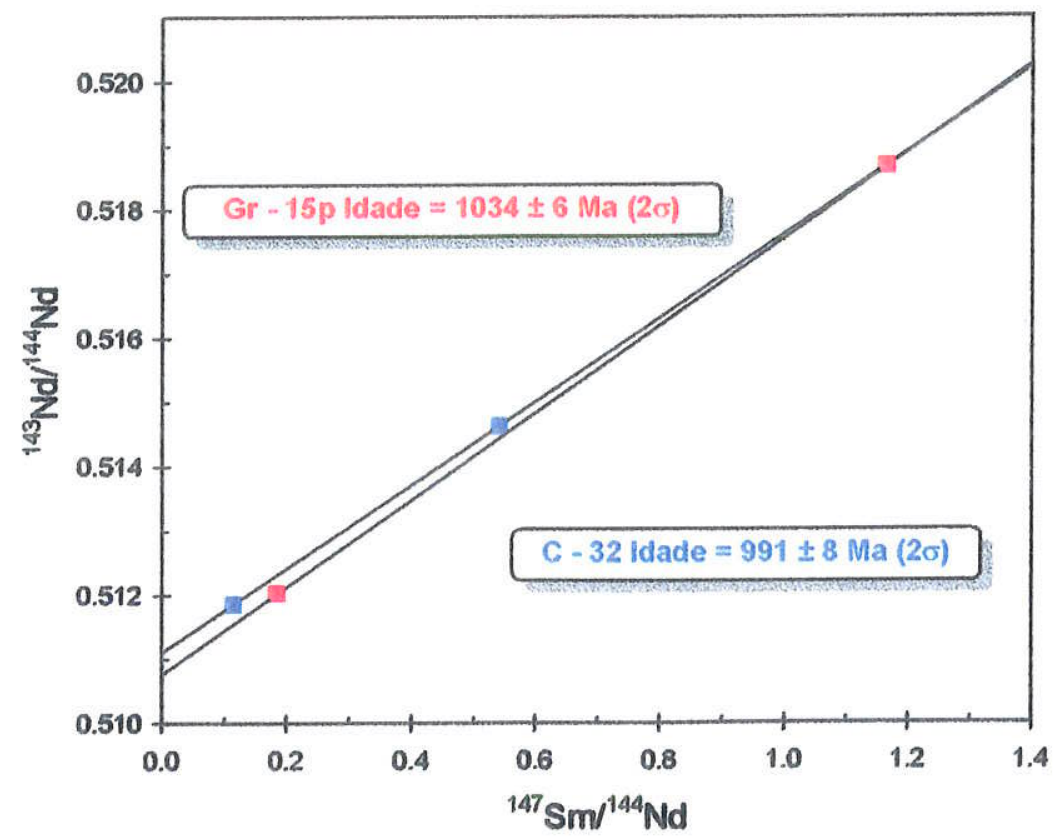

FIGURA 32 - Isócronas Sm-Nd em rocha total e granada do biotita-granada gnaisse $\mathrm{Gr}$-15p e do granulito máfico C-32, pertencentes ao Gnaisse das Margaritas.

representar a época do equilíbrio em facies granulito desta porção do orógeno. Seu valor, de $990 \mathrm{Ma}$, é similar à idade aparente Ar-Ar na hornblenda, de $980\left(T_{f} \sim 500^{\circ} \mathrm{C}\right)$ obtida na mesma amostra (FIGURA 59). A incoerência aparente nas épocas metamórficas pode ser dirimida ao 
interpretar a evolução do granulito máfico C-32 como tendo sido afetado pelo cisalhamento dúctil, em condições de alto grau, com desenvolvimento de $\mathrm{Bt}+\mathrm{Pg} \pm$ Sil em uma segunda foliação milonítica com respeito ao equilíbrio granulítico, fornecendo idade aparente mais jovem (PRANCHA 3 - Fotomicrografias 7 e 8 ).

$O$ equilíbrio da associação mineral no diagrama P-T do gnaisse biotítico Gr-15p, o qual se localiza no mesmo afloramento da amostra Z-365, esta próximo ao campo definido pela associação do granulito C-32 (FIGURA 21). Este campo representa a parte de mais alta temperatura da trajetória ITD, a qual define o retrometamorfismo do evento prógrado (FIGURA 21). A idade mínima para este evento metamórfico prógrado, ao redor de 1034 Ma para esta unidade, é maior do que idade de $1006 \mathrm{Ma}$ (U-Pb SHRIMP em zircão) obtida do leucossoma (Gr-15 A) que injeta os gnaisses (Gr-15p, Gr-15 e Z-365).

O granulito com ortopiroxênio e clinopiroxênio Gr-29, pertencente aos Granulitos do Vergel, exibe uma isócrona mineral $\mathrm{Sm}-\mathrm{Nd}$ com plagioclásio e piroxênio de $929 \pm 32 \mathrm{Ma}$ (MSWD=2.0) (FIGURA 33). A biotita desta associação mineral possivelmente foi equilibrada a uma temperatura menor, fornecendo uma idade aparente mais jovem, ao redor de $915 \mathrm{Ma}$, com erro elevado. A idade aparente em torno de $930 \mathrm{Ma}$ representa o resfriamento do evento metamórfico de - $1000 \mathrm{Ma}$ indicado pelo zircão da mesma amostra pela técnica U-Pb SHRIMP, sendo concordante com as idades Ar-Ar em biotita em torno de $917 \mathrm{Ma}$ obtidas para as amostras GR-29 e V-332 da mesma unidade (FIGURA 44).

As idades modelo $\mathrm{Sm}-\mathrm{Nd} \mathrm{T}_{\mathrm{DM}}$ foram calculadas usando o modelo simples para as amostras regionais do maciço (V-198, D-982, Gr-29, C-32, Gr-15p e Gr-15 A) em que a razão ${ }^{147} \mathrm{Sm} /{ }^{144} \mathrm{Nd}$ entre 0.085 a 0.125 , pode ser considerada dentro da normalidade.

Entretanto, em algumas amostras, o metamorfismo granulítico de aproximadamente $1000 \mathrm{Ma}$ parece ter originado considerável fracionamento na razão $\mathrm{Sm} / \mathrm{Nd}$, na escala da rocha total. Nestas amostras preferiu-se optar pelo modelo em estágio duplo (DE PAOLO et al., 1991). Isto aconteceu para as amostras (V-332, V-314, Gr-29 b e d,), as quais contem respectivamente granada, clinopiroxênio e hornblenda. De acordo com BEA (1996), as granadas de fácies granulito têm notável enriquecimento em Sm e $\mathrm{Nd}$, e os clinopiroxênios e anfibólios tem conteúdos apreciáveis de ETR.

As idades modelo Sm-Nd $T_{D M}$ foram incluídas na FIGURA 34, inclusive o hornblendaplagioclásio-quartzo gnaisse (HP-3) e o plagioclásio-quartzo-hornblenda ortognaisse (SnAnKr1) de RESTREPO- PACE et al. (1997), que apresentam valores entre 1.45 e 1.96 Ga. Não foi 
incluido Tu da amostra Gm 150 (2.35 Ga), um paragnaisse com valor axcessivo na razäo Sm/Nd, por estar muto dierente dos valores medios des demais amostras.

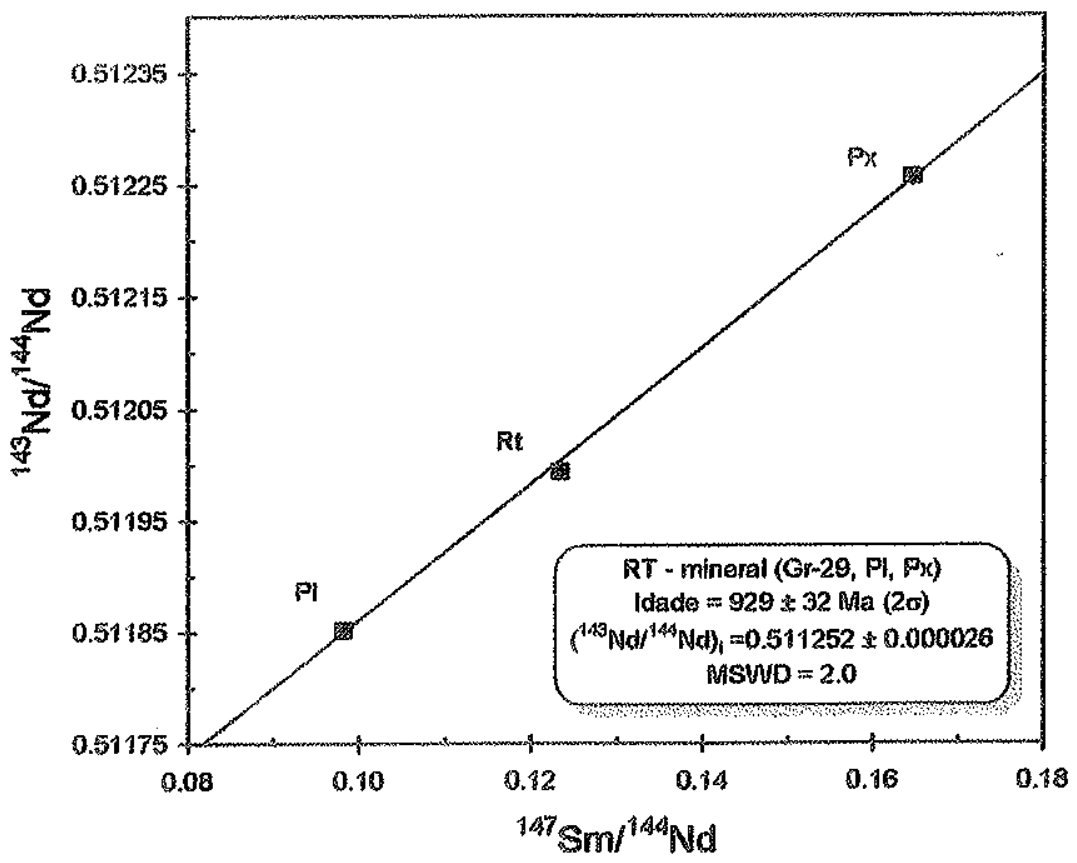

FIGURA 33 - Isóchona Sm-Nd em pocha total, plagioclásio a piroxênio do granuliro enderbítico Gr-29, pertencente aos Granultios do Vergel.

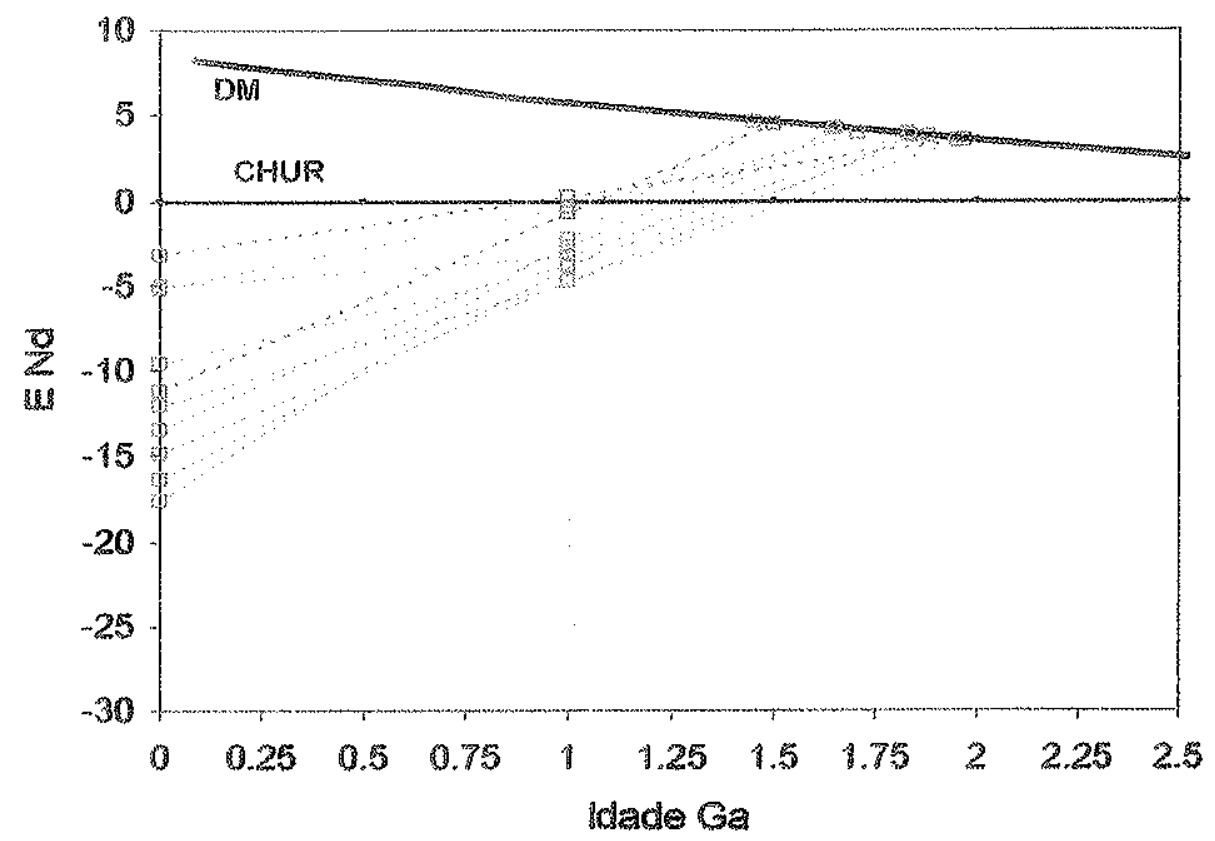

FGURA 34 - Grático Tw das rochas do Macico de Garzón. Inchi as rochas V-198, V-314, Gr-

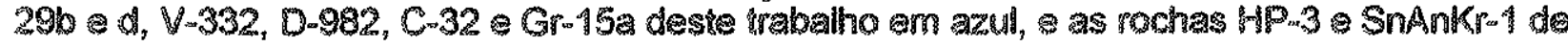
RESTREPO-PACE, ax (1997) am verdo. 
Devido à possivel origem sedimentar das rochas do Maciço de Garzón (KRONENBERG, 1982), e à presença de fontes com diferentes idades sugeridas pela geocronologia do zircão (várias populações de idade do granulito Gr-29), as idades modelo Sm-Nd TDM representam seguramente uma mistura de diferentes fontes, algumas delas mais antigas do que o Mesoproterozóico.

Os valores indicativos de residência crustal sugerem uma possível diferença nas idades dos protolitos. As idades mais antigas devem representar precursores sedimentares com influência de fontes crustais retrabalhadas, e os valores mais jovens implicam na participação de fontes juvenís e até misturas de fontes na formação das rochas. Particularmente, as idades de residência crustal do ortognaisse do Gnaisse de Guapotón-Mancagua sugerem participação de fontes juvenis, mais se pressupõe contaminação do magma original com material da crosta, levando em conta o caráter crustal das unidades adjacentes e o intervalo de tempo decorrido até a cristalização do seu protolito.

\subsection{Geoquímica isotópica $\mathrm{Rb}-\mathrm{Sr}$}

Os dados $\mathrm{Rb} / \mathrm{Sr}$ em rocha total e mineral são apresentados na TABELA 3. Incluíram-se aí os dados de Alvarez (1981 a) e Priem et al. (1989). Os gráficos das FIGURAS 35,36,37 e 38 apresentam a interpretação escolhida para este trabalho, e incluem:

- um diagrama isocrônico rocha total de todas as amostras regionais, e duas isócronas em RT de amostras do mesmo afloramento Gr-29, Gr-29 a,b,d,f,i,e,h e D-806a, D-806b, D-806c.

- Uma isócrona mineral com biotita, plagioclásio e rocha total da amostra Gr-29.

A FIGURA 35 contém todos os dados Rb-Sr em rocha total de 26 amostras disponíveis das rochas regionais do Maciço de Garzón. As 26 amostras não são evidentemente cogenéticas, e seus pontos analíticos estão dispersos no diagrama isocrónico, evidenciando em muitos casos sistemas abertos e mobilidade de $\mathrm{Rb}$ e/ou $\mathrm{Sr}$. Em vista da idade preferencial do metamorfismo regional, de $1000 \mathrm{Ma}$ (U-Pb SHRIMP em zircão da amostra V-198) foi traçada a isócrona de referência de $1000 \mathrm{Ma}$ com uma razão inicial $\left({ }^{87} \mathrm{Sr} /{ }^{86} \mathrm{Sr}\right)_{i}=0.709$, valor médio estimado.

$\mathrm{Na}$ figura 35 estão assinalados os conjuntos formados pelas amostras dos afloramentos Gr-29 e D-806, que serão melhor analisados nas figuras 37 e 39 . Estão assinalados também os pontos analíticos das determinações fornecidas por ALVAREZ (1981 a) e PRIEM et al. (1989). As idades em torno de $1200 \mathrm{Ma}$ (ALVAREZ, 1981a e PRIEM et al., 1989) foram interpretadas como a época do metamorfismo dos Granulitos do Vergel. Os pontos analíticos de ALVAREZ (1981 a) estão próximos à isócrona de referência de 1000 Ma. Entretanto, os dados de 
TABELA 3 - Análises $\mathrm{Rb}-\mathrm{Sr}$ em rocha total e mineral de amostras do Maciço de Garzón

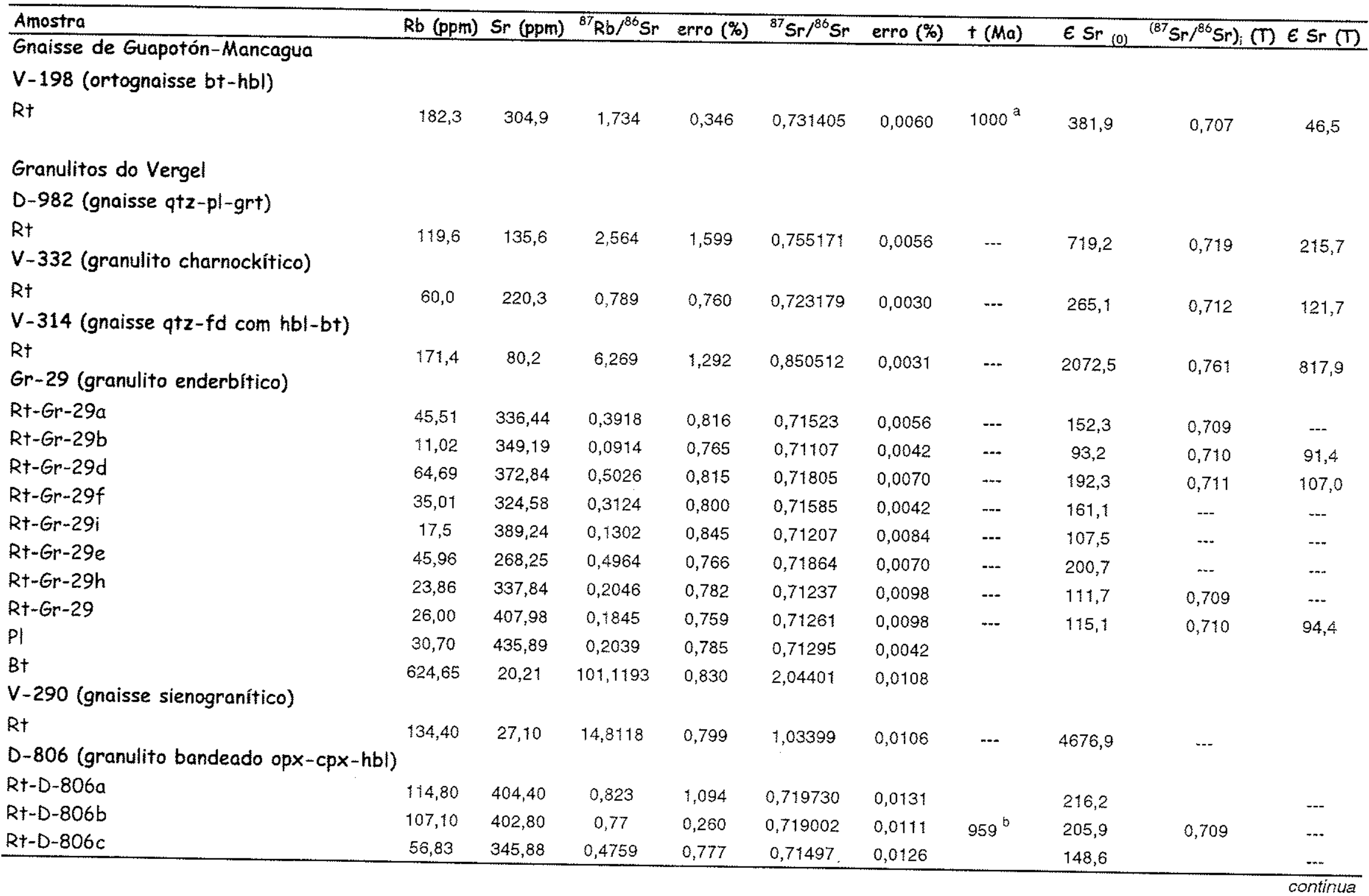




\begin{tabular}{|c|c|c|c|c|c|c|c|c|c|c|}
\hline Amostra & $\mathrm{Rb}(\mathrm{ppm})$ & Sr (ppm) & ${ }^{87} \mathrm{Rb} /{ }^{86} \mathrm{Sr}$ & erro (\%) & ${ }^{87} \mathrm{Sr} /{ }^{86} \mathrm{Sr}$ & erro $(\%)$ & $+(M a)$ & $\epsilon \mathrm{rr}_{(0)}$ & $\left.{ }^{(87} \mathrm{Sr} /{ }^{86} \mathrm{Sr}\right)_{1}(\mathrm{~T})$ & $E \mathrm{Sr}(\mathrm{T})$ \\
\hline \multicolumn{11}{|l|}{ CIA-1 (gnaisse hbl-bt) ** } \\
\hline Rt & 162 & 169 & 2,775 & 0,5 & 0,749165 & 0,02 &.-- & $\cdots$ & $\cdots$ & --- \\
\hline \multicolumn{11}{|l|}{ CIA-3 (gnaisse hbl-bt) ** } \\
\hline Rt & 151 & 175 & 2,503 & 0,5 & 0,745809 & 0,02 & $-\cdots$ & -- & --- & $\ldots$ \\
\hline \multicolumn{11}{|l|}{$\begin{array}{l}\text { CIA-10 (gnaisse granítico) } * * \\
\text { Rt }\end{array}$} \\
\hline 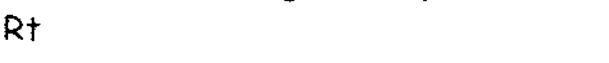 & 78,7 & 309 & 0,7369 & 0,5 & 0,721156 & 0,02 & $\cdots$ & --- &.-- & --- \\
\hline \multicolumn{11}{|l|}{ CIA-14 (aplito grt) $\star \star$} \\
\hline Rt & 187 & 120 & 4,555 & 0,5 & 0,796238 & 0,02 & $\cdots$ & $\cdots$ & $\cdots$ & -- \\
\hline \multicolumn{11}{|l|}{$\begin{array}{l}\text { JAA-1177 (leucossoma } q t z-f d-b t) * \\
\text { Pt }\end{array}$} \\
\hline$R+$ & $\{79,4$ & 226,5 & 2,30 & 0,05 & 0,7428 & 0,0007 &.-- & $\cdots$ & $\cdots$ & 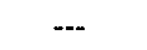 \\
\hline \multicolumn{11}{|l|}{ JAA-1174 (gnaisse $q^{t z-f d-b t) *}$} \\
\hline Rt & $\{15,8$ & 334 & 1,00 & 0,02 & 0,7210 & 0,0016 & $\cdots$ & $\cdots$ & $\cdots$ & $\cdots$ \\
\hline \multicolumn{11}{|l|}{ JAA-1179 (leucossoma qtz-fd-bt) * } \\
\hline Rt & 129,5 & 515 & 0,73 & 0,01 & 0,7145 & 0,0018 & $\cdots$ & -- & --- & -- \\
\hline \multicolumn{11}{|l|}{ JAA-1180 (gnaisse $q t z-f d-b t) *$} \\
\hline$R+$ & 120,5 & 370,0 & 0,94 & 0,02 & 0,7207 & 0,0009 &.-- & --- & $\ldots$ & $\cdots$ \\
\hline \multicolumn{11}{|l|}{ Gnaisse das Margaritas } \\
\hline \multicolumn{11}{|l|}{ Gr-15p (paragnaisse com bt-grt) } \\
\hline Rt & 145,5 & 101,0 & 4,206 & 1,070 & 0,797340 & 0,0070 & -- & 1317,8 & 0,737 & 481,4 \\
\hline \multicolumn{11}{|c|}{ Gr-15A (gnaisse qtz-fd-bt, leucossoma injeção) } \\
\hline Rt & 156,4 & 376,5 & 1,205 & 0,249 & 0,726955 & 0,0130 & $1000^{\circ}$ & 318,7 & 0,710 & 90,8 \\
\hline${ }^{*}$ Dados de Alvarez (1981a) & & & $a=R_{i} d e 0.7$ & & $\mathrm{~T}=1000 \mathrm{Ma}$ & & & & & \\
\hline $\begin{array}{l}\text { ** Dados de Priem et al. }(1989) \\
\mathrm{Rt}=\text { rocha total, } \mathrm{Pl}=\text { plagioclásio, } \mathrm{Bt}=\text { biotita }\end{array}$ & & & $\begin{array}{l}b=\text { Ri de } 0.7 \\
c=\text { Pi de } 0.7\end{array}$ & & & & & & & \\
\hline
\end{tabular}


PRIEM et al. (1989) encontram-se muito dispersos com respeito a essa isócrona de referência, e tem que ser vistos com precaução.

A amostra V-198 do Gnaisse de Guapotón-Mancagua fornece idade U-Pb SHRIMP em zircão, de cristalização magmática, ao redor de $1140 \mathrm{Ma}$ posterior metamorfismo a $1005 \mathrm{Ma}$. Seu ponto analítico $\mathrm{Rb}-\mathrm{Sr}$ situamse praticamente sobre a isócrona de referencia, confirmando a idade metamórfica U-Pb. O valor de $1596 \pm 300$ Ma (PRIEM et al., 1989), o qual sustenta a correlação litológica e geocronológica dos gnaisses de Guapotón-Mancagua com os gnaisses do Escudo de Guiana, ao que parece, não tem significado geológico.

O leucossoma Gr-15 do Gnaisse das Margaritas (FIGURA 35), com idade de cristalização de $1005 \mathrm{Ma} \mathrm{U}-\mathrm{Pb}$ em zircão, apresenta também o seu ponto analítico próximo da isócrona de referência. Desta forma, pode ser considerado como concordante em idade, desde que para a sua razão inicial $\left({ }^{87} \mathrm{Sr} /{ }^{86} \mathrm{Sr}\right)$, seja assumido o valor de 0.712 .

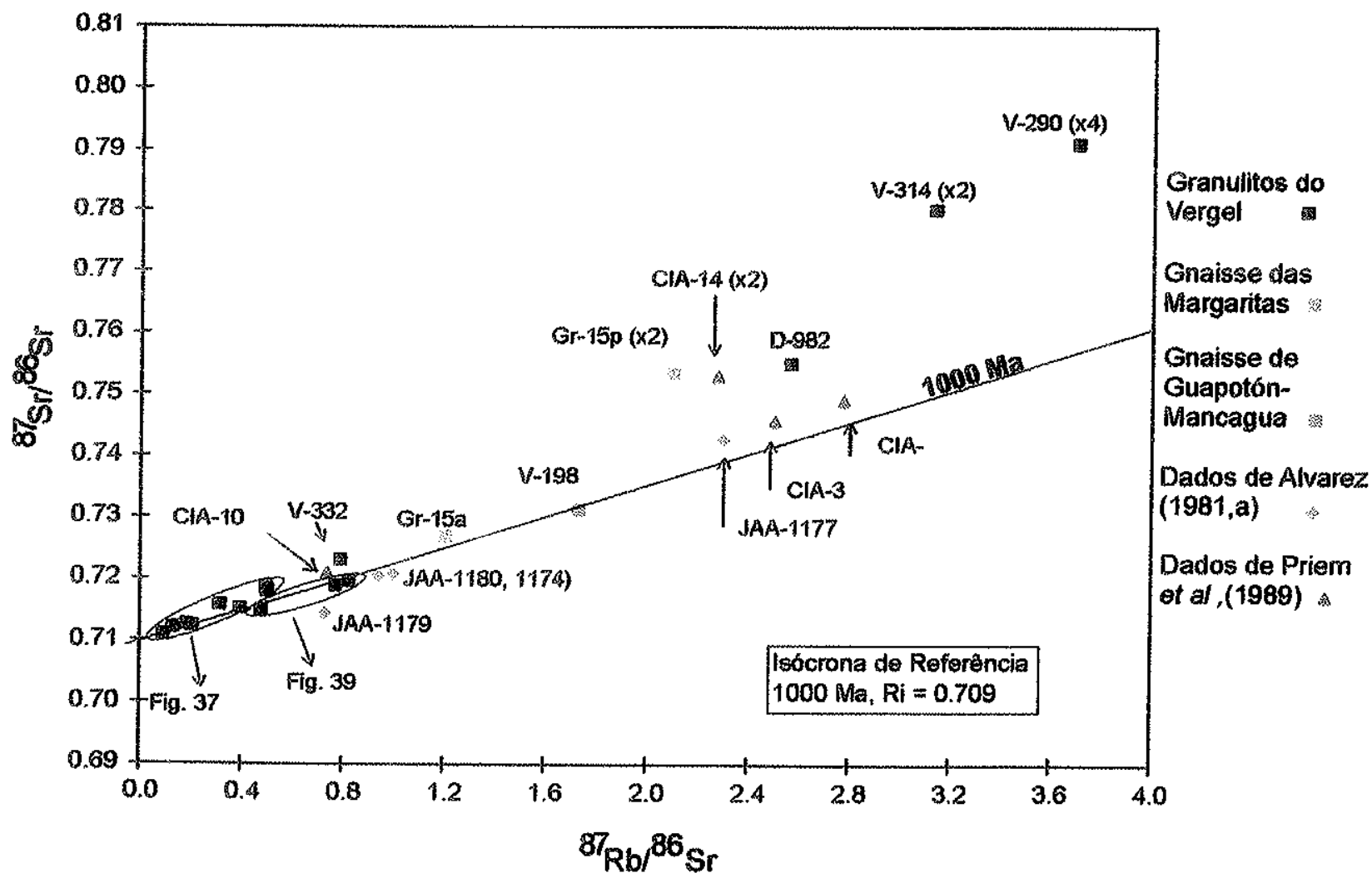

FIGURA 35 -Diagrama isocrónico Rb-Sr em rocha total das amostras regionais do Maciço de Garzón. Inclui dados isotópicos desta pesquisa (amostras Gr-29, Gr-29a, b, d, e, f, h, i, D-806 a,b,c, V-332, D-982, V-314, V-290, Gr-15 A, Gr-15p e V-198), de ALVAREZ, 1981 (JAA$1174,1177,1179$ e 1180), de PRIEM ar al., 1989 (CIA-1, 3, 10, 14)

Os pontos analíticos das amostras V-314, V-290, D-982 e Gr-15p desta pesquisa, bem como a ClA-14 de Priem of al. (1989) condicionam pelo menos duas interpretaçóes alternativas. A 
primeira é aquela já mencionada, de mobilidade química durante o metamorfismo provocando dispersão no diagrama isocrónico. Na segunda, as amostras de rocha total preservariam de alguma forma a herança de razões isotópicas de $\mathrm{Sr}$ mais elevadas, correspondendo a protolitos de idade mesoproterozóica. Embora o sistema $\mathrm{Rb}-\mathrm{Sr}$ experimente mobilidade durante o metamorfismo, segundo FAURE \& POWELL (1972) esta mobilidade afetaria em algum grau a razão ${ }^{87} \mathrm{Sr} /{ }^{86} \mathrm{Sr}$ das amostras mas não apagaria completamente a sua origem, sobretudo quando a rocha tivesse razões ${ }^{87} \mathrm{Sr} /{ }^{86} \mathrm{Sr}$ elevadas.

As razões iniciais a $1000 \mathrm{Ma}\left({ }^{87} \mathrm{Sr}{ }^{86} \mathrm{Sr}\right)_{i-1000}$ para as amostras aparentemente menos mobilizadas (V-332, Gr-29-a,h, D-806-a,b,c) dos Granulitos do Vergel e a amostra Gr-15a do Gnaisse das Margaritas estão acima de 0.709. Tais elevadas razões iniciais podem indicar participação de material siálico em sua origem, o que é também sugerido pelas idades modelo Sm-Nd T TM. A amostra V-198 de um ortognaisse do Gnaisses de Guapotón-Mancagua tem o valor de 0.707 para sua razão inicial a $1000 \mathrm{Ma}$ (TABELA 3). Este valor mais baixo, se comparado com os granulitos e gnaisses, sugere participação de maior proporção de material mantélico na formação do seu protolito.

Os parâmetros $\epsilon_{\mathrm{Nd}}$ e $\epsilon_{\mathrm{Sr}}$ para todas as amostras regionais do Maciço de Garzón são incluídos no diagrama da FIGURA 36, e confirmam a derivação crustal das rochas estudadas com valores negativos de $\epsilon_{\mathrm{Nd}}$ e altamente positivos do $\epsilon_{\mathrm{S} r}$.

O diagrama isocrónico Rb-Sr (FIGURA 37) contem os dados de rocha total de 8 amostras cogenéticas, do mesmo afloramento, (granulitos enderbíticos Gr-29, Gr-29-a,b,d,e,f,i,h) pertencentes aos Granulitos do Vergel, com baixos valores da razão $\mathrm{Rb} / \mathrm{Sr}$. As amostras formam uma nuvem no diagrama, e definem apenas uma tendência. Para este granulito Gr-29 foi obtida uma idade do metamorfismo de aproximadamente $1000 \mathrm{Ma}$ com base na datação U$\mathrm{Pb}$ SHRIMP em zircão. Todas as amostras posicionam-se à esquerda e acima da isócrona de referência construída para $1000 \mathrm{Ma}$ com razão inicial de 0.709 . Este sistema isotópico, na escala de afloramento, parece indicar mobilidade, da mesma forma que os granulitos em geral na escala regional. O espalhamento observado nos valores $\mathrm{Rb} / \mathrm{Sr}$ pode-ser devido ao comportamento isotópico variável durante o metamorfismo granulítico, com empobrecimento relativo em $\mathrm{Rb}$, o qual nessas condições é mais móvel do que o $\mathrm{Sr}$. Com efeito, na Tabela 3 pode ser verificado que os teores de $\mathrm{Rb}$ das amostras do afloramento $\mathrm{Gr}-29$ são as menores reportadas para os Granulitos do Vergel.

O sistema isotópico da isócrona mineral $\mathrm{Rb}-\mathrm{Sr}(\mathrm{Gr}-29, \mathrm{Bt}, \mathrm{Pl})$ forneceu uma idade de $923 \pm 8$ Ma (MSWD $=0.6)$ (FIGURA 38). Isto indica que, mesmo que o sistema de rocha total desta 


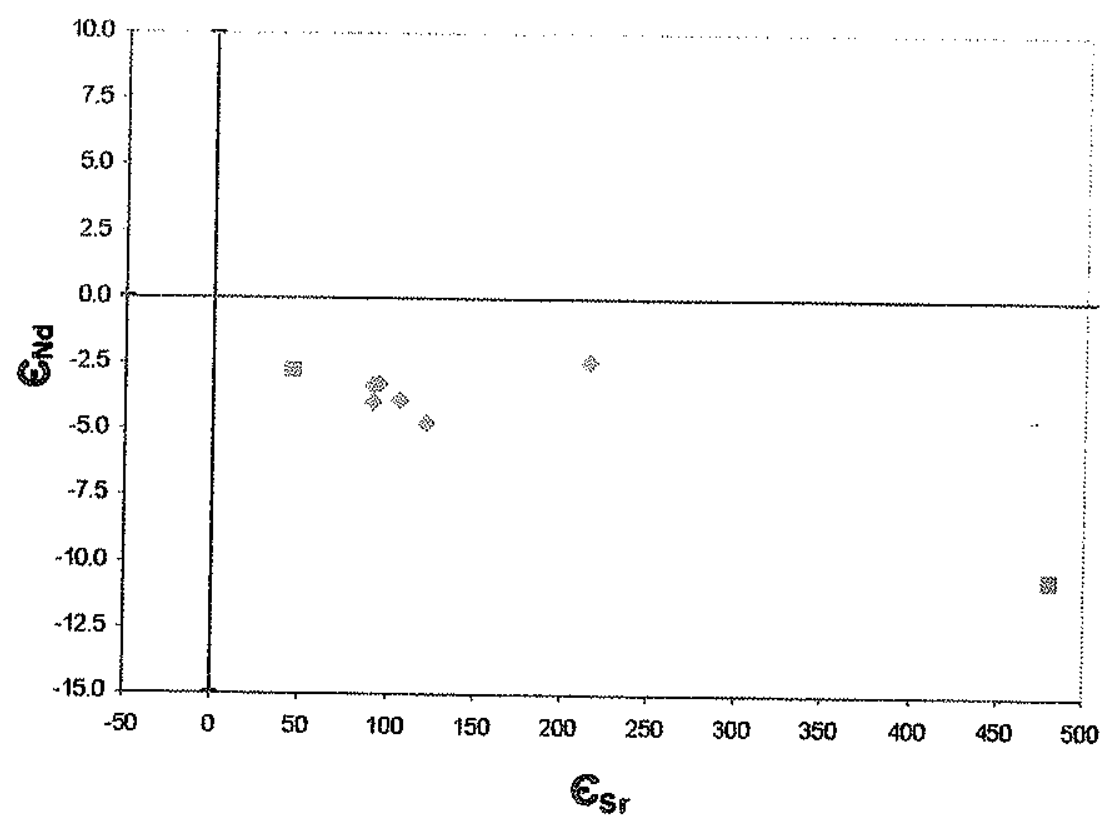

FIGURA 36 - Gráfico $\epsilon_{\text {Ndd }} / \epsilon_{\text {Sr }}$ para as amostras do Maciço de Garzón. As rochas dos Granulitos do Vergel estäo em azul, do Gnaisse das Margaritas em verde, e do Gnaisse de
Guapotón-Mancagua em vermelho.

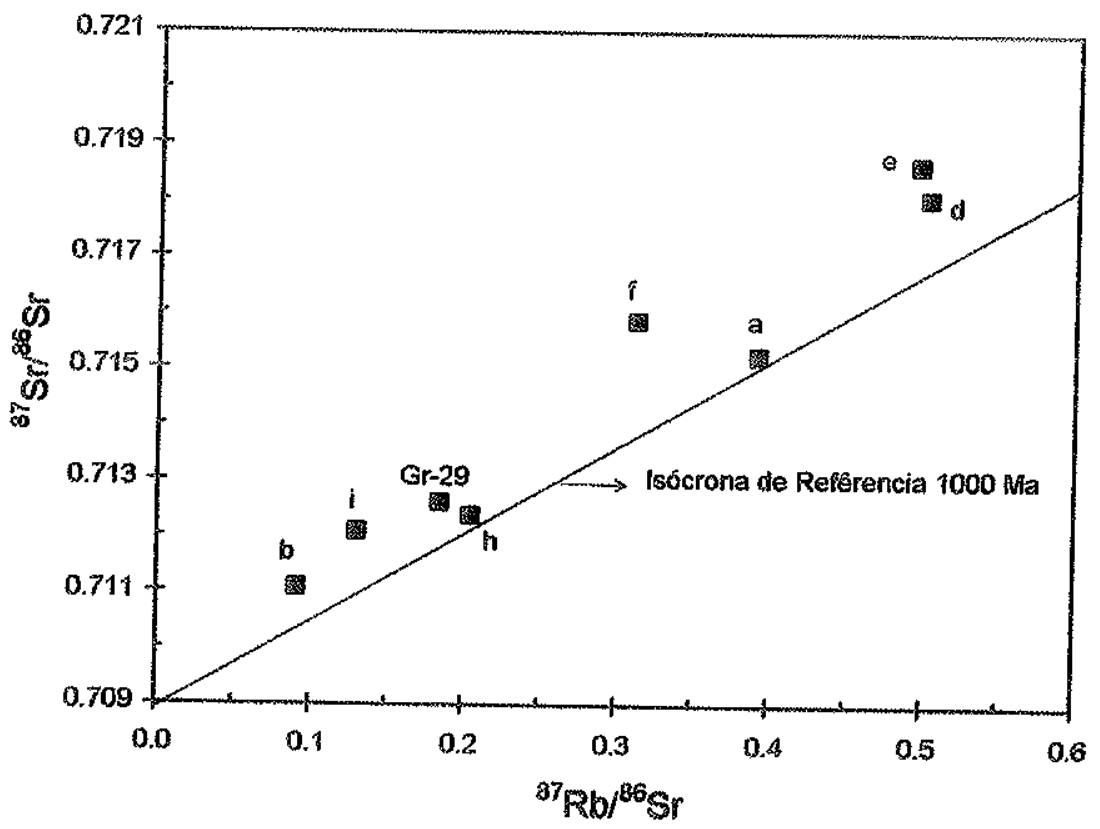

FIGURA 37 - Diagrama isocrônico Rlo-Sr para as amostras cogenéticas de rocha total Gr-29 Gr-29a, b, d, e, f, $h$, i pertencentes aos Granulitos do Vergel. 


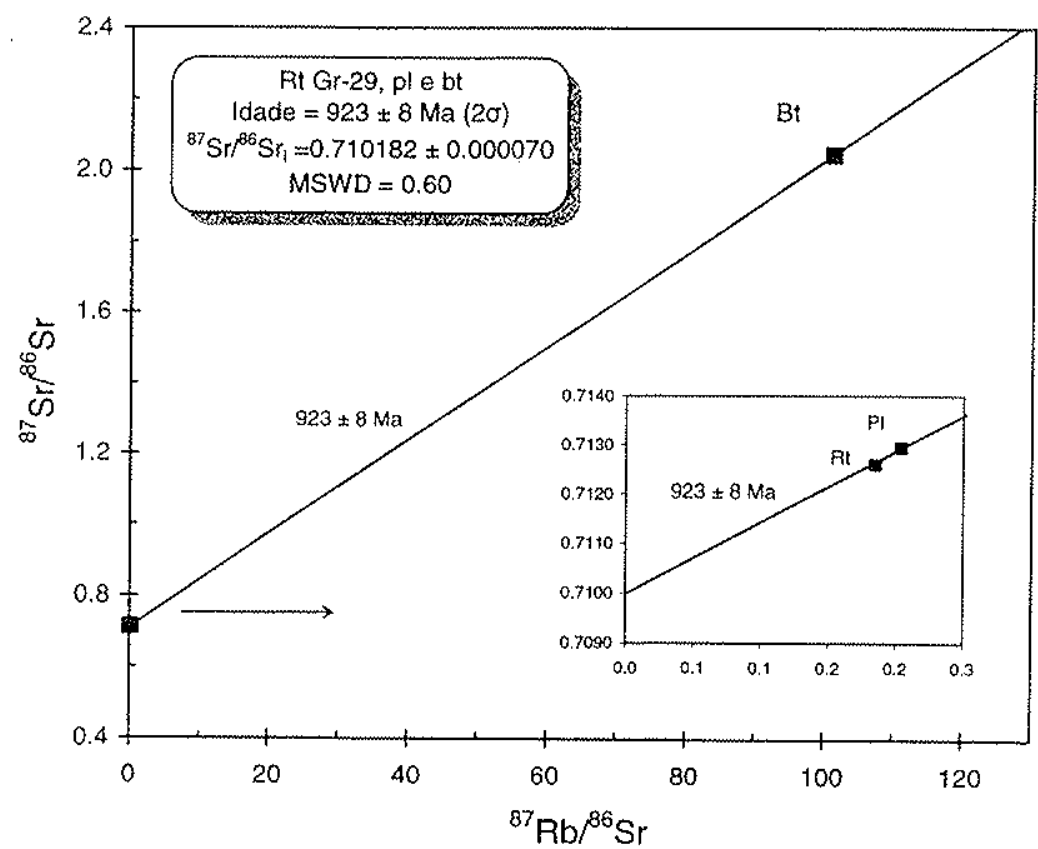

FIGURA 38 - Isócrona Rb-Sr em rocha total, plagioclásio e biotita da amostra Gr-29, pertencente aos Granulitos do Vergel.

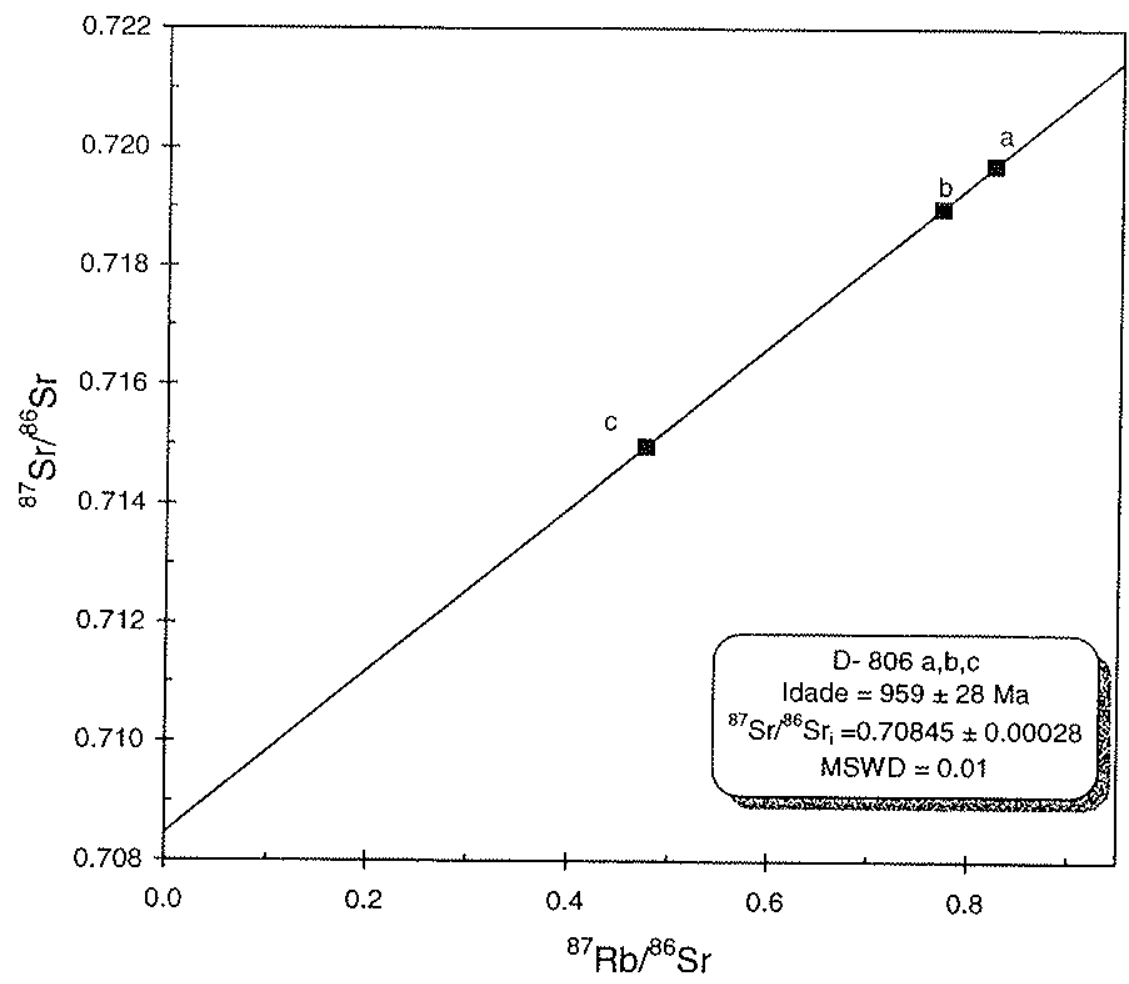

FIGURA 39 - Isócrona Rb-Sr em rocha total das amostras do granulito bandado D-806a, b, c pertencentes aos Granulitos do Vergel.

amostra tenha sido aberto e modificado durante o metamorfismo a $1000 \mathrm{Ma}$ (FIGURA 35), OS seus minerais foram isotopicamente homogeneizados (FAURE \& POWELL, 1972). Esta idade 
representa essencialmente o fechamento da biotita abaixo de temperatura de $350^{\circ} \mathrm{C}$ (MUNHÁ \& TASSINARI, 1999) durante a exumação e o concomitante resfriamento do metamorfismo de $1000 \mathrm{Ma}$, sendo concordante com a idade Ar-Ar da mesma biotita de $914 \pm 3 \mathrm{Ma}$ (FIGURA 43).

A isócrona de três amostras de rocha total de um granulito bandado (D-806-a,b,c) fomece uma idade de $959 \pm 28$ (FIGURA 39), aqui interpretada como apresentando possivelmente a época do metamorfismo granulítico. Esta idade não difere muito, considerando a sua pouca precisão, daquela obtida para o metamorfismo da amostra Gr-29 (U-Pb em zircão), de $1000 \mathrm{Ma}$.

\subsection{Datações Ar-Ar em minerais separados}

46 idades Ar-Ar em 18 minerais separados (biotita e hornblenda) de 12 amostras foram obtidas do Gnaisse de Guapotón-Mancagua (V-198), Granulitos do Vergel (V-332, Gr-29, D-986, D982, V-309), Gnaisse das Margaritas (C-302, C-271, C-299, C-32, Gr-15p), e do gnaisse granodioritico do Complexo Migmatítico da Cocha Rio Tellez (A-746), pelo método de aquecimento por etapas. As idades são compiladas na TABELA 4, as amostras estão localizadas no ANEXO I, e os dados analíticos completos estão no ANEXO VII.

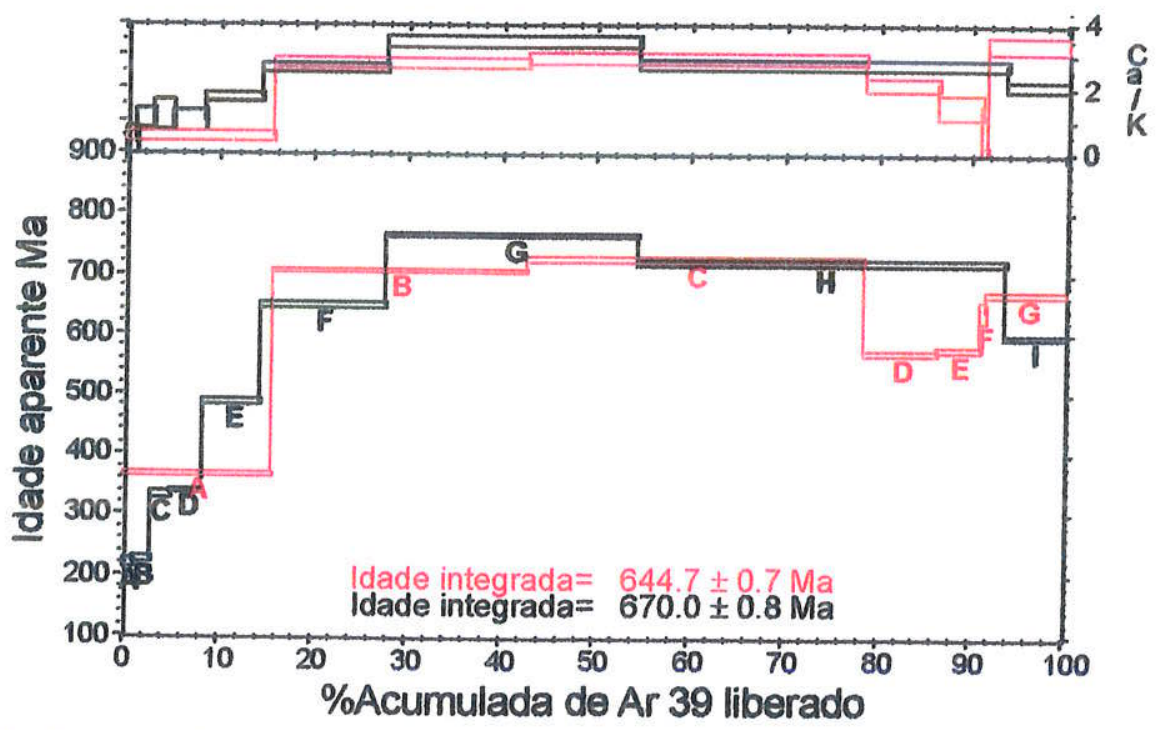

FIGURA 40 - Espectro de degaseificação da hornblenda, amostra V-198

Do Gnaisse de Guapotón-Mancagua foi analisada a amostra V-198. Dois gräos de hornblenda definem espectros, semelhantes com importantes perdas de argônio nas primeiras etapas (FIGURA 40). As etapas intermediarias definem um pseudo-plateau em torno de $710 \mathrm{Ma}$. Os três grãos de biotita, embora tenham espectros com comportamento intemo similar de liberação do gás e perdas de argônio nos primeiros steps, mostram idades aparentes muito diferentes, e idades integradas entre 299 e $480 \mathrm{Ma}$ (FIGURA 41). Tais espectros indicam aquecimentos, possivelmente associados com hidrotermalismo, com idade máxima em torno 
TABELA 4 - Idades Ar-Ar em biotita e hornblenda das amostras do Maciço de Garzón e do Complexo Migmatitico da Cocha Rio Tellez

\begin{tabular}{|c|c|c|c|}
\hline \multirow[t]{2}{*}{ Amostra } & Idade & Idade Integrada & Idade \\
\hline & Plateau Ma & Ma & Ideograma* Mo \\
\hline \multicolumn{4}{|c|}{ Gnaisse de Guapotón-Mancagua } \\
\hline \multicolumn{4}{|l|}{ V-198 (ortognaisse bt-hbl) } \\
\hline \multirow[t]{3}{*}{$\mathrm{Bt}$} & & $479.0 \pm 0.5$ & \\
\hline & & $417.0 \pm 0.4$ & \\
\hline & & $298.8 \pm 0.4$ & \\
\hline \multirow[t]{2}{*}{$H|-|$} & & $644.7 \pm 0.7$ & \\
\hline & & $670 \pm 0.8$ & \\
\hline
\end{tabular}

\section{Granulitos do Vergel}

V-332 (granulito charnockítico)

$\mathrm{B}+$

Gr-29 (granulito enderbítico)

$\mathrm{B \dagger}$

D-986 (granulito máfico)

$\mathrm{B}+$

$\mathrm{Hbl}$

D-982 (gnaisse com bt-grt)

$\mathrm{Bt}$

V-309 (granulito máfico)

B十

$\mathrm{Hbl}$

$\begin{array}{ccc}919.7 \pm 0.8 & 918.8 \pm 0.8 & \\ 985 \pm 3^{\star *} & 919.2 \pm 0.8 & 917 \pm 3 \\ 907.4 \pm 1.0 & 904.2 \pm 0.8 & \\ & & \\ 914.3 \pm 1.3 & 914.3 \pm 1.3 & \\ 913.6 \pm 1.1 & 912.1 \pm 1.1 & 914 \pm 3 \\ & 937.1 \pm 1.2 & \end{array}$

$782.3 \pm 0.8$

$863.6 \pm 0.8$

$834 \pm 0.8$

$6980 \pm 50$

$6520 \pm 40$

$857.4 \pm 0.7$

$859.8 \pm 0.8$
$928.2 \pm 1.2 \quad 930.4 \pm 0.9$
$976 \pm 0.9 \quad 974.8 \pm 0.9$
$964 \pm 1.0 \quad 963 \pm 1$

$977.7 \pm 1.6 \quad 1002 \pm 1.3$

$981 \pm 1.6 \quad 999.5 \pm 1.5$

$979 \pm 3$

993.9 (step I) $\quad 1044 \pm 1.6$

Gnaisse das Margaritas

C-302 (gnaisse qtz-pl com biotita)

$\mathrm{B}+$
$1007.3 \pm 0.9 \quad 1006.6 \pm 0.8$

$956.1 \pm 1.1 \quad 947.3 \pm 0.9$

$1011.6 \pm 1.1 \quad 1007.6 \pm 0.9$
$1009 \pm 2$

continua 


\begin{tabular}{|c|c|c|c|}
\hline & & & $\begin{array}{l}\text { continua } \\
\text { conclusão }\end{array}$ \\
\hline \multirow[t]{2}{*}{ Amostra } & Idade & Idade Integrada & Idade \\
\hline & Plateau Ma & $\mathrm{Ma}$ & Ideograma* Ma \\
\hline C-271 (granulito enderbítico) & $1044.7 \pm 1.1$ & $1034.1 \pm 0.9$ & \\
\hline Bt & $\begin{array}{c}1017.8 \pm 1.2 \\
1032.9 \pm 1.1^{\star \star}\end{array}$ & $\begin{array}{l}1015.2 \pm 1.2 \\
1028.2 \pm 1.0\end{array}$ & $1032 \pm 6$ \\
\hline \multicolumn{4}{|c|}{ C-299 (gnaisse com bt-opx-cpx-hbl) } \\
\hline Bt & $\begin{array}{l}977.3 \pm 1.9 \\
981.1 \pm 1.2\end{array}$ & $\begin{array}{l}972.6 \pm 1.1 \\
980.1 \pm 0.8\end{array}$ & $980 \pm 2$ \\
\hline $\mathrm{Hbl}$ & & $\begin{array}{l}1076.5 \pm 1.1 \\
1067.5 \pm 1.2\end{array}$ & \\
\hline C-32 (granulito máfico) & & & \\
\hline $\mathrm{B}+$ & $\begin{array}{l}954.6 \pm 1.3 \\
948.3 \pm 1.1\end{array}$ & $\begin{array}{l}954.8 \pm 0.8 \\
945.2 \pm 0.8\end{array}$ & $951 \pm 3$ \\
\hline $\mathrm{Hbl}$ & $982.3 \pm 1.6$ & $\begin{array}{c}992.2 \pm 1.0 \\
1001.2 \pm 0.9\end{array}$ & $984 \pm 3$ \\
\hline Gr-15p (gnaisse biotitico) & & & \\
\hline Bt & $\begin{array}{c}964 \pm 1.1 \\
974.2 \pm 1.1 \\
962 \pm 1.1 \\
\end{array}$ & $\begin{array}{c}960.9 \pm 1.0 \\
966.3 \pm 0.9 \\
957 \pm 1.1 \\
\end{array}$ & $967 \pm 3$ \\
\hline $\begin{array}{l}\text { Complexo migmatitico da Cocha } \\
\text { A-746 (granodiorito gnaissico }\end{array}$ & & & \\
\hline$B+$ & $\begin{array}{c}22.6 \pm 0.3 \\
22.8 \pm 0.18 \\
22.6 \pm 0.2^{* \star}\end{array}$ & $\begin{array}{c}24.6 \pm 0.4 \\
22.8 \pm 0.18 \\
21.17 \pm 0.14\end{array}$ & $22.4 \pm 0.4$ \\
\hline $\mathrm{Hbl}$ & $36.4 \pm 0.6$ & $\begin{array}{l}35 \pm 0.4 \\
40 \pm 0.5\end{array}$ & \\
\hline
\end{tabular}

* Idade média ponderada dos dois ou três grãos, tomando apenas as etapas que formam plateau ${ }^{* *}$ Pseudoplateau 
de $200 \mathrm{Ma}$. Os eventos térmicos teriam ocasionado perdas parciais de Ar radiogênico nos dois minerais, sendo que a hornblenda foi mais retentiva do que a biotita. A presença de plagioclásio sericitizado na lâmina delgada reforça a interpretação de alteração hidrotermal, a qual pode ter relação com a fase de magmatismo Triássico a Jurássico que afeta a borda ocidental do Maciço de Garzón.

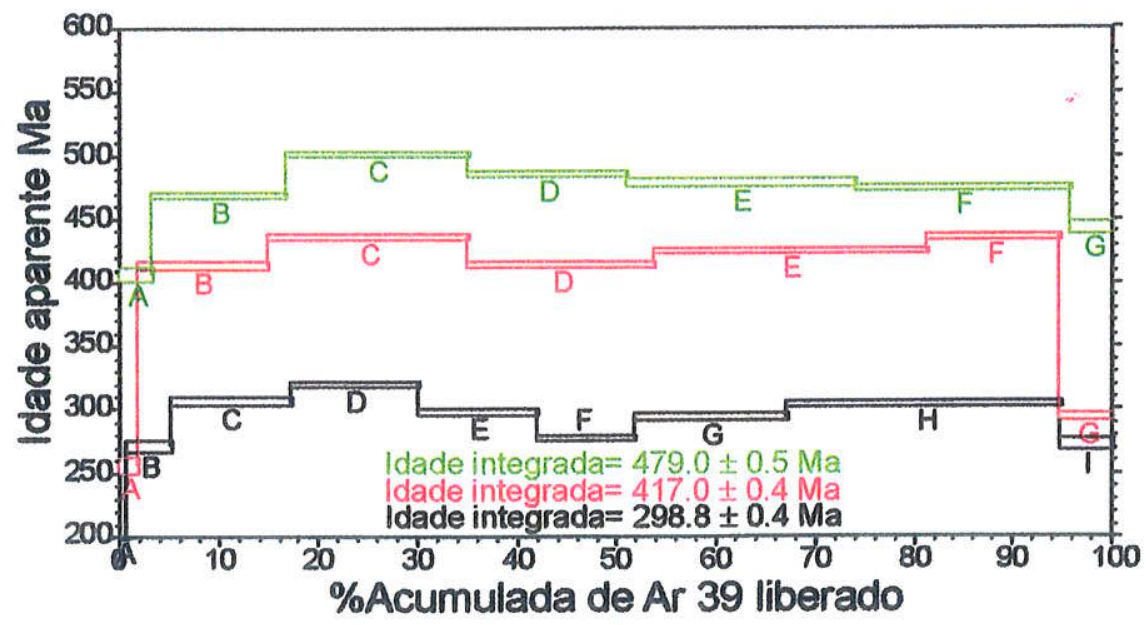

FIGURA 41 - Espectro de degaseificação da biotita, amostra V-198

Dos Granulitos do Vergel, realizaram-se datações Ar-Ar nas amostras V-332, Gr-29, D-986, D982 e V-309.

Os três grãos da biotita da amostra V-332 apresentam espectros regulares com plateaus de até $95 \%$ do gás liberado e pequenas perdas de argônio nas primeiras etapas. Dois grãos apresentam idades próximas de $920 \mathrm{Ma}$, e o terceiro apresenta idade pouco menor, de $907 \mathrm{Ma}$ (FIGURA 42).

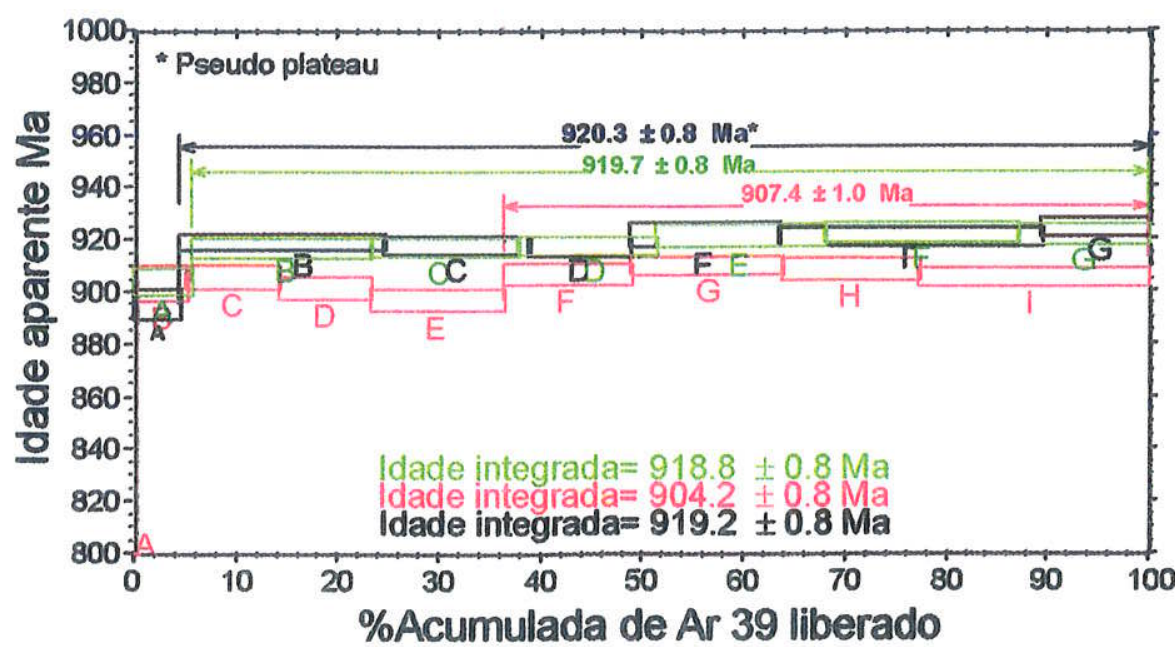

FIGURA 42 - Espectro de degaseificação da biotita, amostra V-332 
Dos três grãos de biotita da amostra $\mathrm{Gr}$-29, dois apresentaram espectros que definem bons patamares com pequenas perdas de argônio nas primeiras etapas de degaseificação, possivelmente por alteração nas bordas dos cristais. Os dois plateaus, representados por 95 e $100 \%$ do gás liberado, fornecem idade de 914 Ma. O terceiro grão apresenta idade aparente maior, de $937 \mathrm{Ma}$ (FIGURA 43).

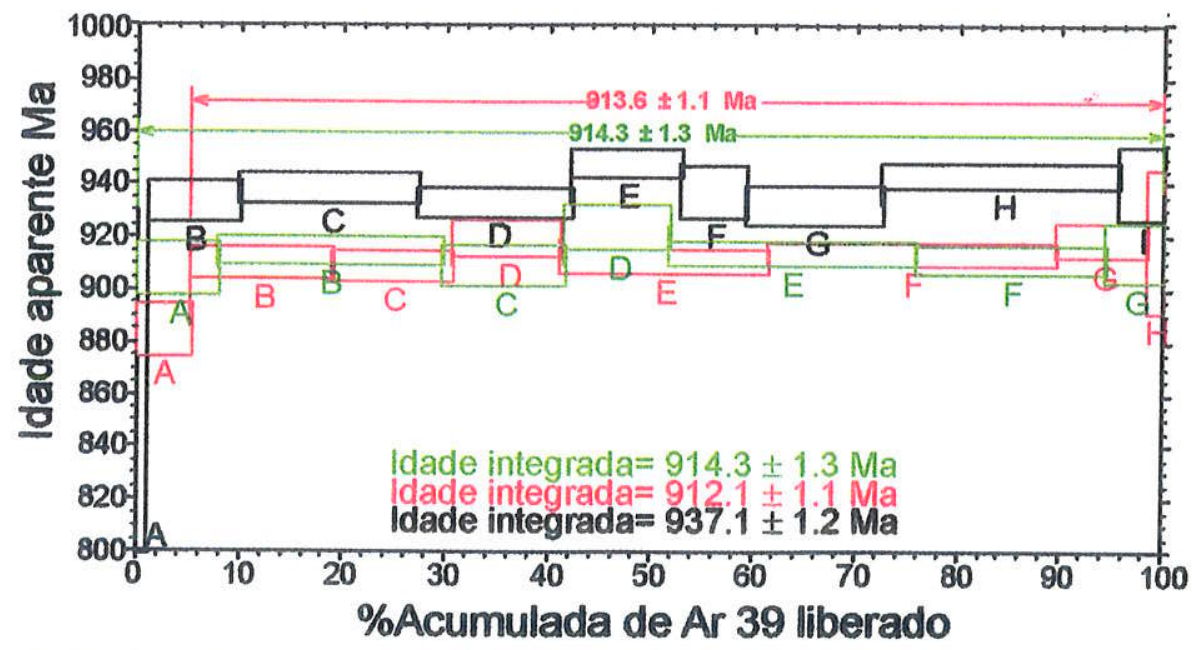

FIGURA 43 - Espectro de degaseificação da biotita, amostra Gr-29

As idades dos ideogramas que incluem os plateaus atingidos pelas amostras V-332 e Gr-29 são de 917 \& $3 \mathrm{Ma}$ e $914 \pm 3 \mathrm{Ma}$, respectivamente (FIGURA 44). Estas idades são interpretadas como o resfriamento do metamorfismo de $1000 \mathrm{Ma}$, determinado pela datação U/Pb SHRIMP em zircão metamórfico. O resfriamento da biotita metamórfica, ao redor de 915 Ma a uma temperatura de $350^{\circ} \mathrm{C}$ para esta parte do orógeno, pode ser comparada com a

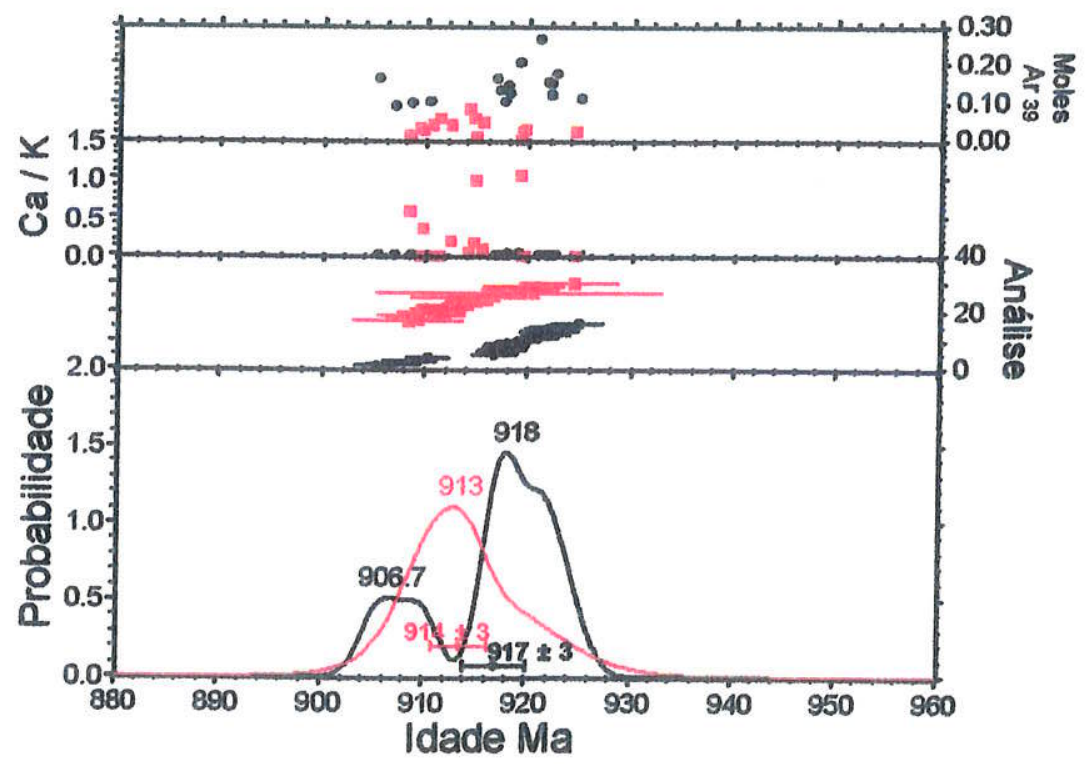

FIGURA 44 - Ideogramas para os grãos das biotitas das amostras Gr-29 e V-332 
idade Sm-Nd da isócrona RTgranada, de $935 \mathrm{Ma}$, ama temperaura de 600 "C para a amostra $\mathrm{V}-332$. A taxa de resfriamento correspondente é relativamente rápida, de $23^{\circ} \mathrm{C} / \mathrm{Ma}$ (FIGURA 68).

Os dois grãos de biotita da amostra D-982 apresentam espectros irregulares com idades integradas de 858 e 860 Ma (FIGURA 45), indicando claramente perdas de argônio. A amostra deve ter sido afetada por evento térmico posterior ao metamorfismo, datado em 1000 Ma pelo método U/Pb SHRIMP em zircão.

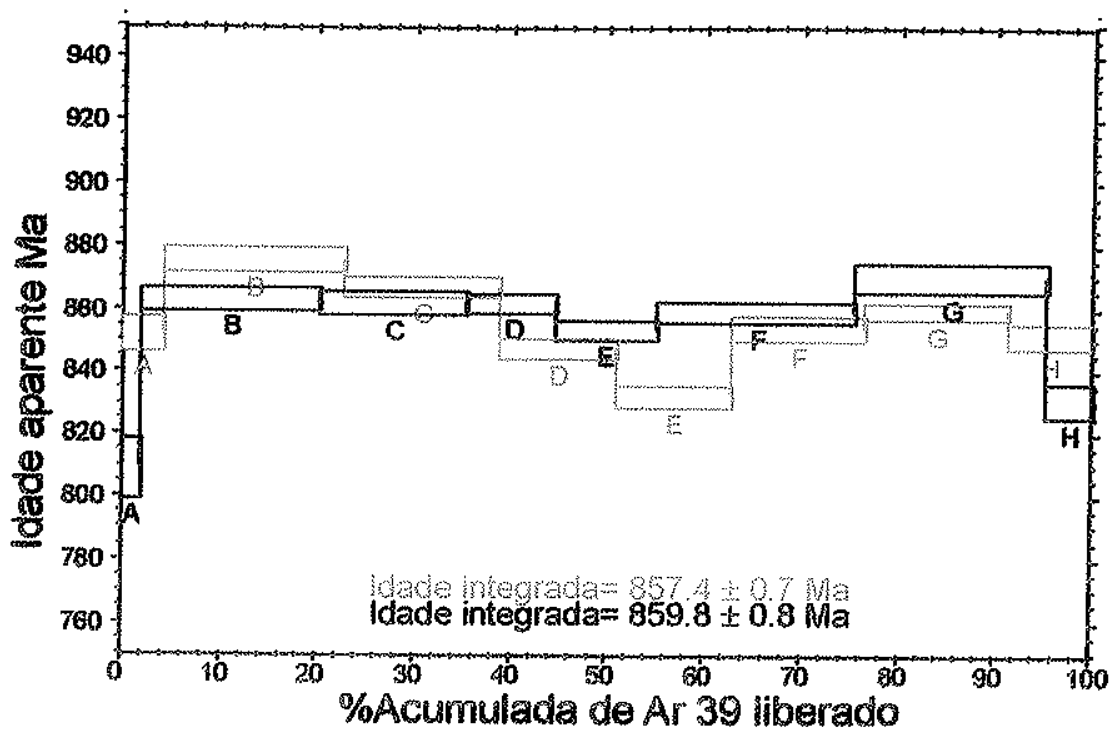

FIGURA 45 - Espectro de degaseificação da biotita, amostra 0-982

Dois grãos da homblenda da amostra D-986 mostraram espectros complexos com idades integradas absurdas, maiores que $6000 \mathrm{Ma}$ (FIGURA 46). Este sistema isotópico está afetado svidentemente por ${ }^{40} \mathrm{Ar}$ em excesso, fomecendo idades sem significado geológico. Os tres grãos da biotita da mesma amostra D-986 apresentam espectros irregulares com pequena evidência de ${ }^{40} \mathrm{Ar}$ em excesso, e idades integradas entre 782 a $863 \mathrm{Ma}$ (FIGURA 47). A amostra foi provavelmente afetada por um evento térmico, podendo-se inferir que a idade ao redor de 860 Ma do grão com o espectro mais homogêneo possa talvez indicar a idade mínima para o resfriamento do metamortismo. Este valor é similar às idades integradas das biotitas da amostra D-982.

As idades aparentes de aproximadamente $860 \mathrm{Ma}$, obtidas nas biotitas das amostras D-986 D-982, localizadas na parte ocidental dos Granulitos do Vergel, são portanto atribuídas a processos de hidrotemalismo que podem ter sido locais, näo afetando toda a unidade. Tais aquecimentos podem ter sido a causa da liberação de Ar das fases potássicas (micas e 
feldspatos), incorporando argônio 40 em excesso nas fases de pouco K, como os anfibólios.

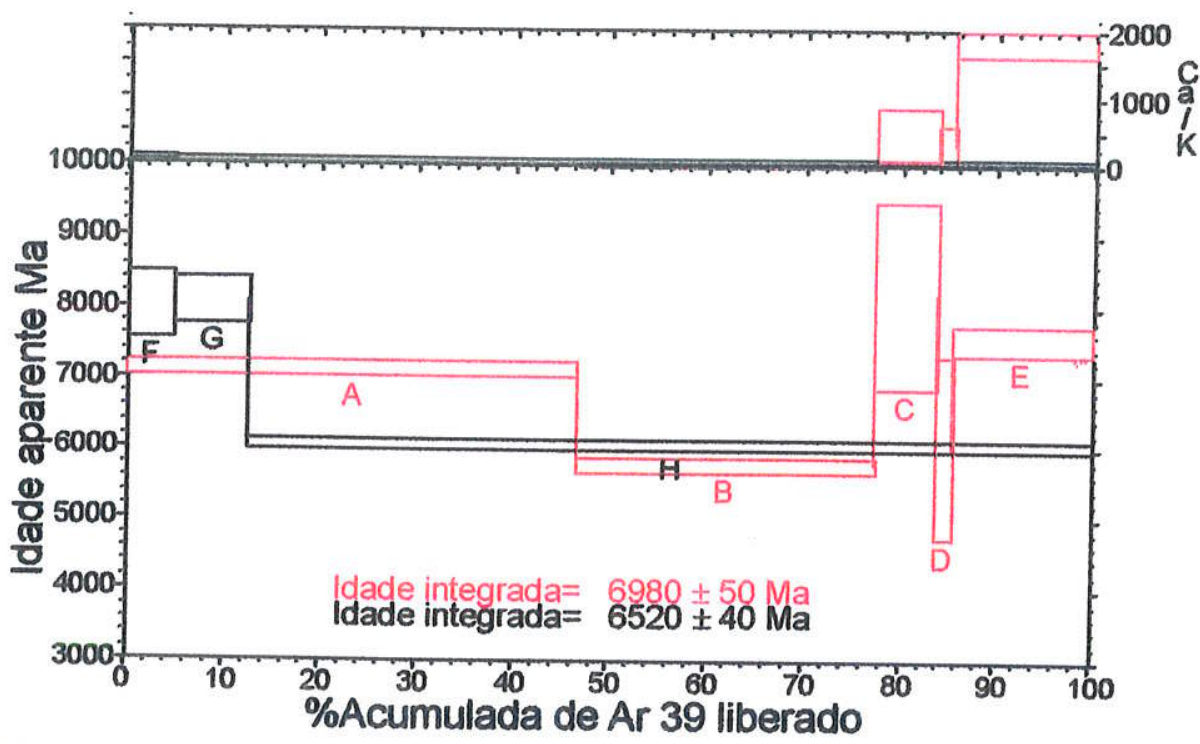

FIGURA 46 - Espectro de degaseificação da hornblenda, amostra D-986

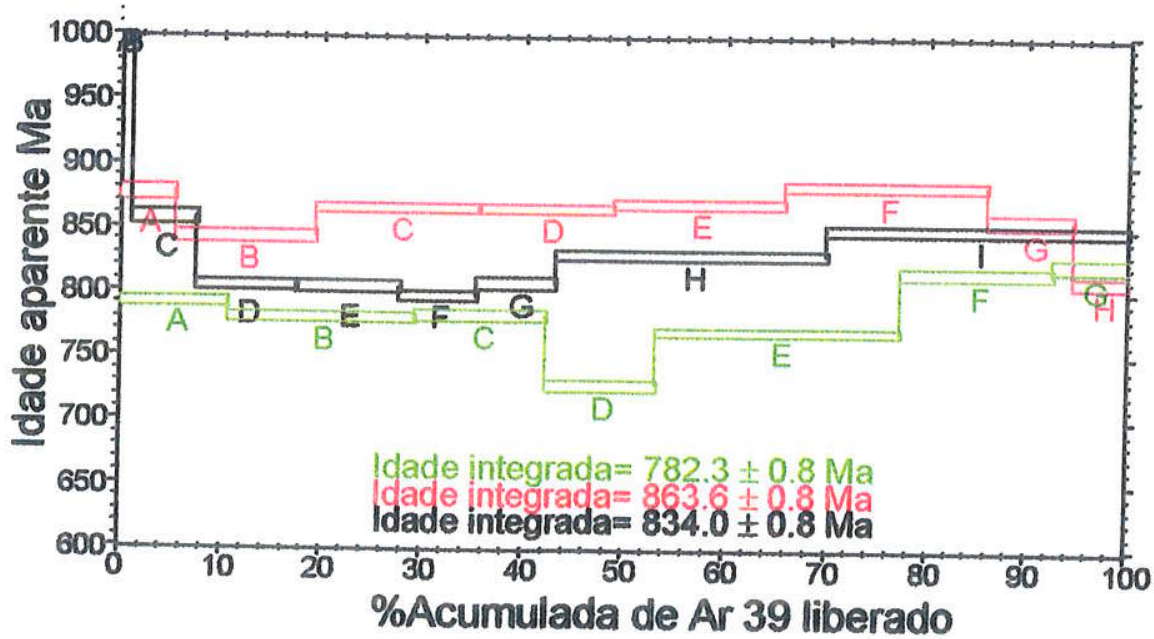

FIGURA 47 - Espectro de degaseificação da biotita, amostra D-986

Os espectros de degaseificação dos três grãos de hornblenda da amostra V-309, com claras evidências de excesso de argônio 40 nas primeiras etapas, atingem patamares com até 90 \% do gás liberado, com idades de 978 e 980 Ma para dois deles (FIGURA 48). A idade média dos steps que conformam plateau é de $979 \pm 3$ Ma (FIGURA 49). Os três grãos da biotita da mesma amostra apresentam espectros com patamares bem definidos, com liberação do gás de até do $97 \%$ e pequenas perdas de argônio nas primeiras etapas de degaseificação. As idades plateau são de 976, 964 e 928 Ma (FIGURA 50). A similaridade das duas primeiras idades e a quantidade considerável de gás liberado em suas etapas sugerem que o sistema foi homogeneizado com idade média de $971 \pm 4$ Ma (FIGURA 51). Foi descartado o resultado do 
terceiro grão, com menores quantidades de gás liberado. As idades concordantes dos ideogramas para a hornblenda e biotita dessa amostra são interpretadas como o resfriamento do episódio metamórfico.

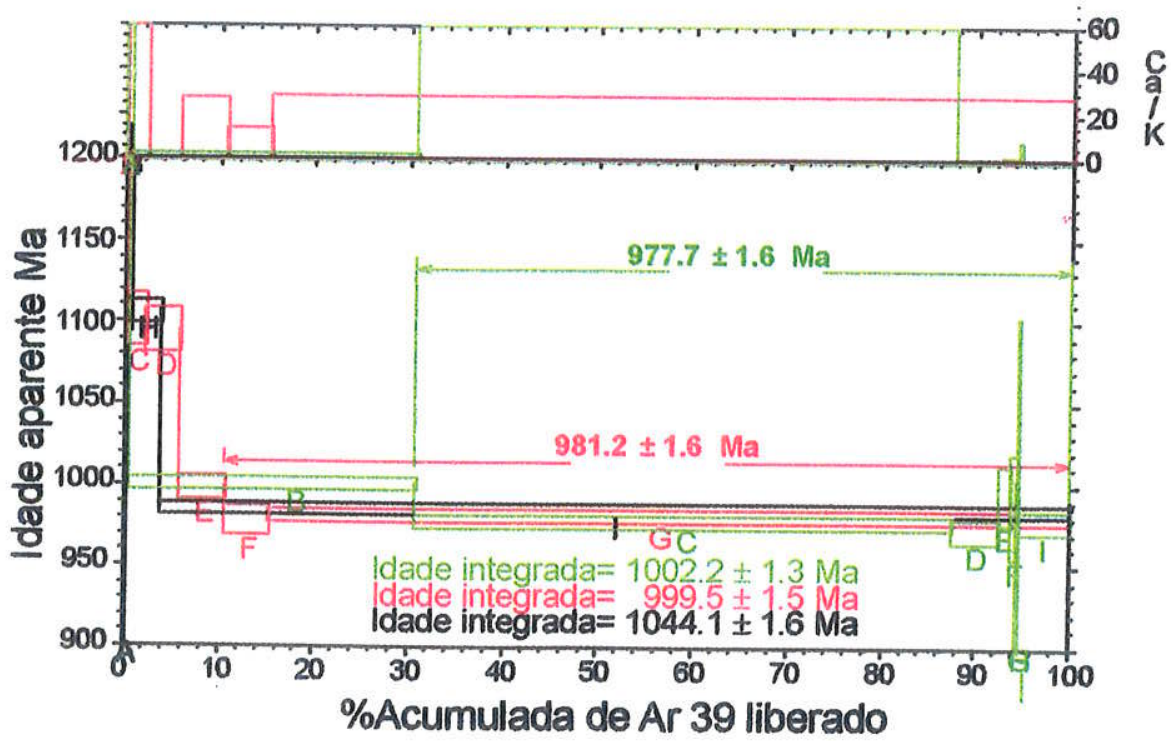

FIGURA 48 - Espectro de degaseificação da hornblenda, amostra V-309

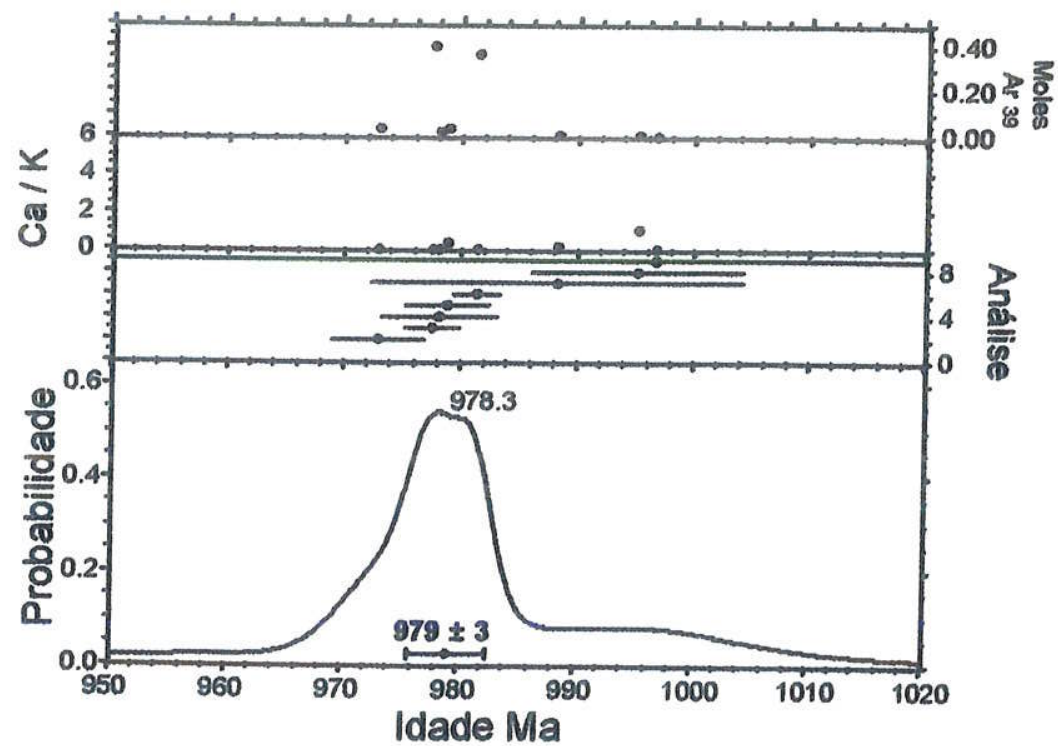

FIGURA 49 - Ideograma para os grãos da hornblenda, amostra V-309

As idades Ar-Ar das biotitas das amostras V-332 e Gr-29 ao redor de 915 Ma são claramente mais jovens do que as obtidas na amostra V-309, refletindo uma história térmica diferente. Elas são interpretadas como refletindo o resfriamento do episódio metamórfico dos Granulitos do Vergel abaixo da temperatura de $350^{\circ} \mathrm{C}$. Estas idades são semelhantes, dentro dos erros experimentais, com as idades $925 \pm 50$ Ma K-Ar (ALVAREZ \& LINARES, 1985) e $902 \pm 20$ Ma 
(VAN DER WIEL, 1991), em hornblenda, $912 \pm 35$ Ma K-Ar em flogopita (PRIEM et al., 1989), e $911 \pm 2$ Ma Ar-Ar em hornblenda (RESTREPO-PACE, 1995) (QUADRO 1).

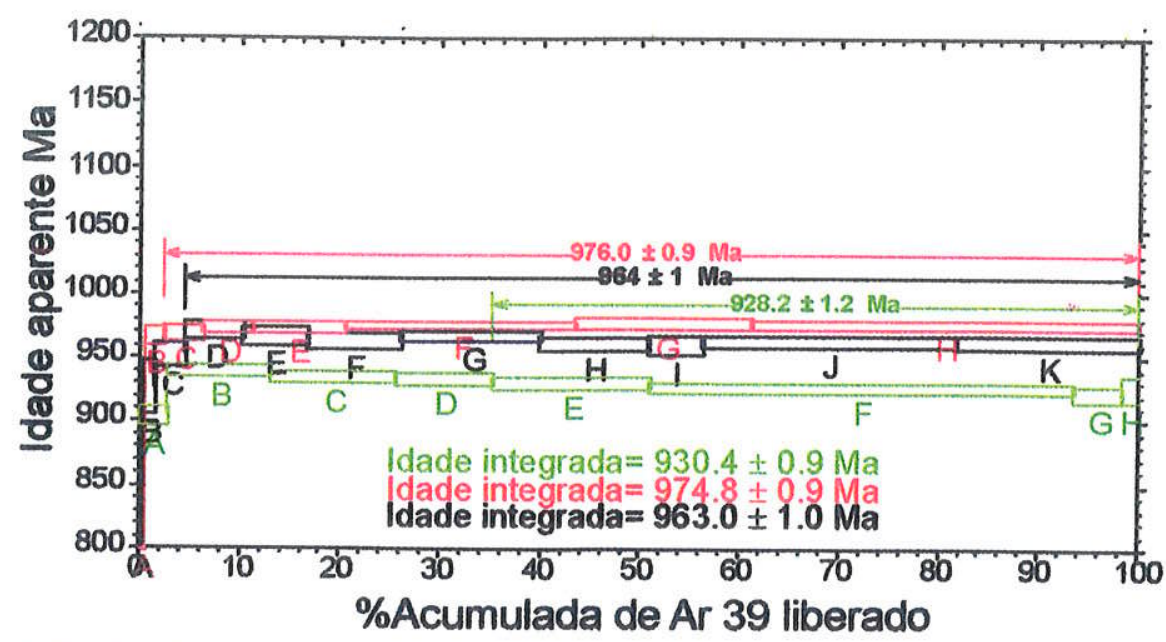

FIGURA 50 - Espectro de degaseificação da biotita, amostra V-309

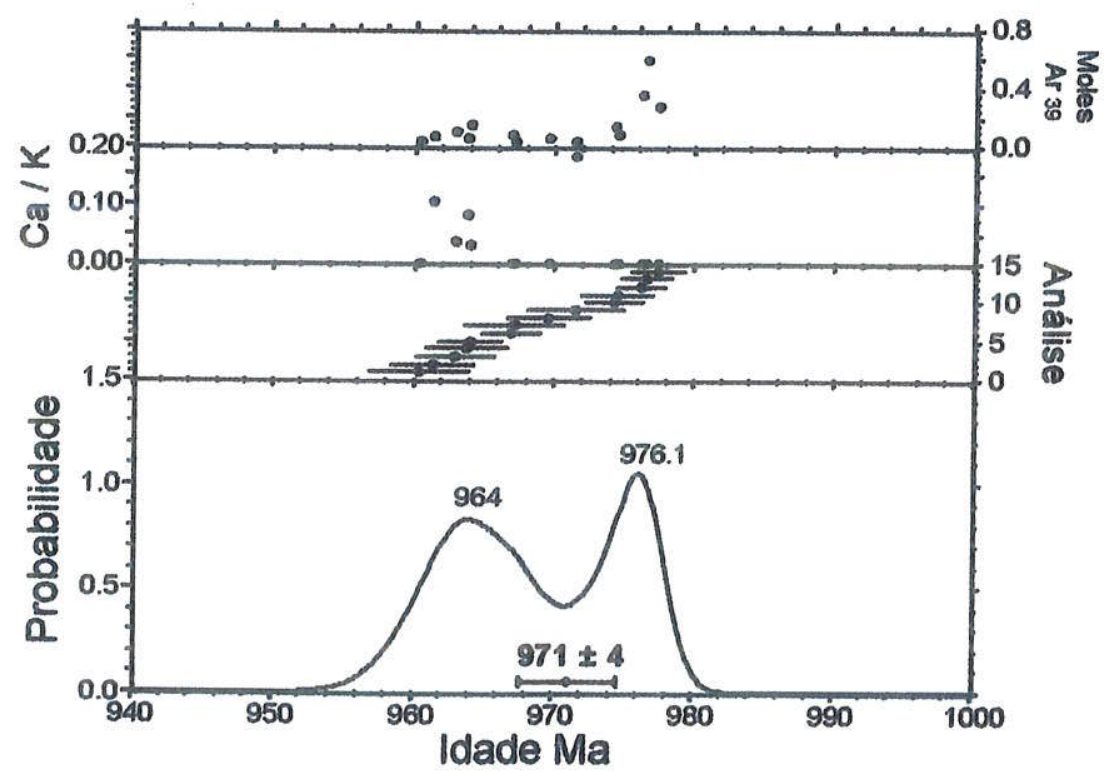

FIGURA 51 - Ideograma para os grãos da biotita, amostra V-309

Do Gnaisse das Margaritas analisaram-se pelo método Ar-Ar as amostras C-302, C-271, C. 299, C-32 e Gr-15p.

Dois dos três grãos de biotita da amostra C-302 definem plateaus com pequena perda de argônio nas primeiras etapas de degaseificação, e idades concordantes de 1012 e $1007 \mathrm{Ma}$ (FIGURA 52). O terceiro grão mostrou idade aparente consideravelmente mais baixa, e não foi considerado na interpretação. A idade média dos dois steps concordantes é de $1009 \pm 2 \mathrm{Ma}$ (FIGURA 53). 


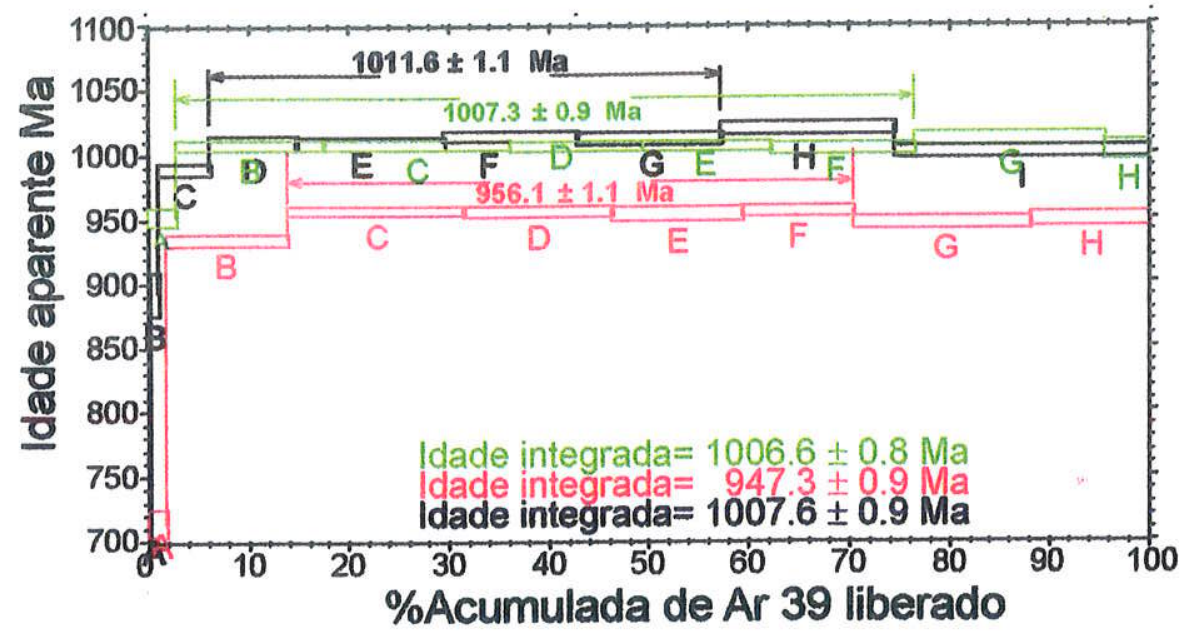

FIGURA 52 - Espectro de degaseificação da biotita, amostra C-302

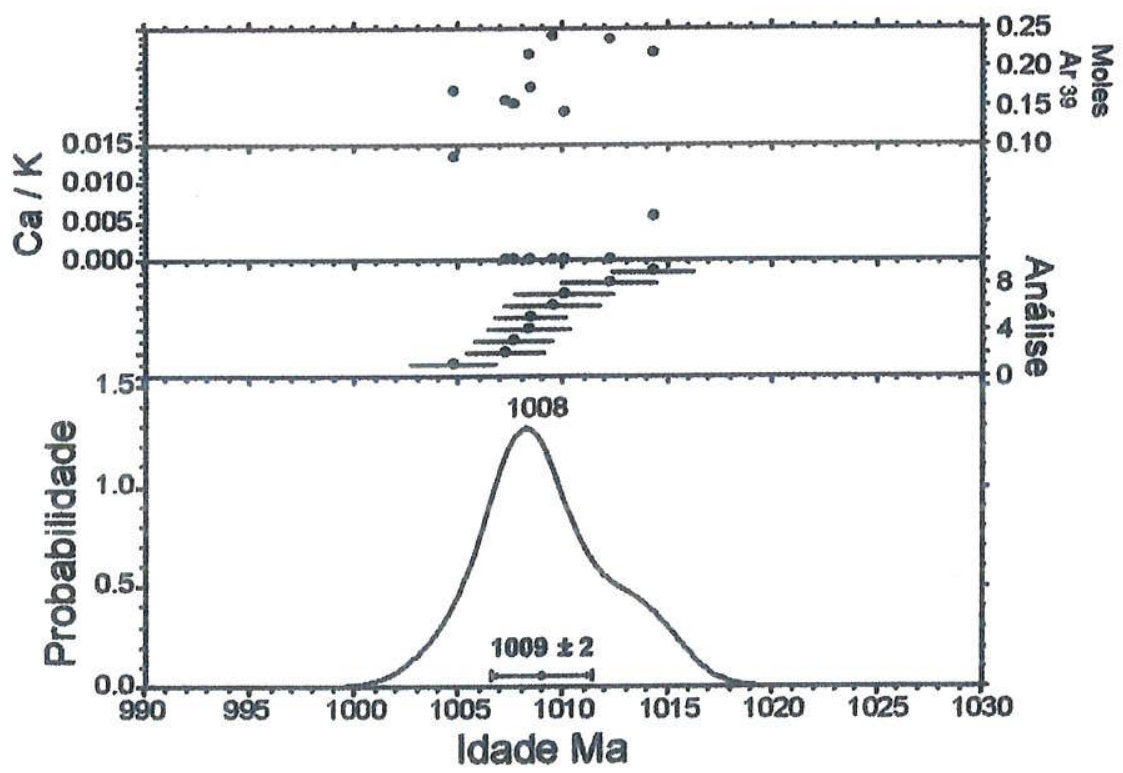

FIGURA 53 - Ideograma para os grãos da biotita, amostra C-302

Os espectros dos três grãos de biotita da amostra C-271 apresentam pequenas perdas de argônio nos primeiros steps. Obtiveram-se plateaus e pseudoplateau com idades entre 1018 e $1045 \mathrm{Ma}$ (FIGURA 54), com idade média de $1032 \pm 6 \mathrm{Ma}$ (FIGURA 55).

Os dois grãos de homblenda da amostra C-299 possuem excesso de ${ }^{40} \mathrm{Ar}$ nas etapas iniciais e intermediárias de degaseificação. Apesar disto, nas etapas finais define-se um pseudoplateau em torno de $980 \mathrm{Ma}$ (FIGURA 56). Os dois grãos de biotita da mesma amostra apresentam plateaus com ate $95 \%$ de gás liberado com idades de 981 e 977 Ma e pequenas perdas de argônio no primeiro step (FIGURA 57). A idade média dos steps que definem plateau é de 980 $\pm 2 \mathrm{Ma}$ (FIGURA 58), em plena concordância com as idades aparentes da hornblenda. 


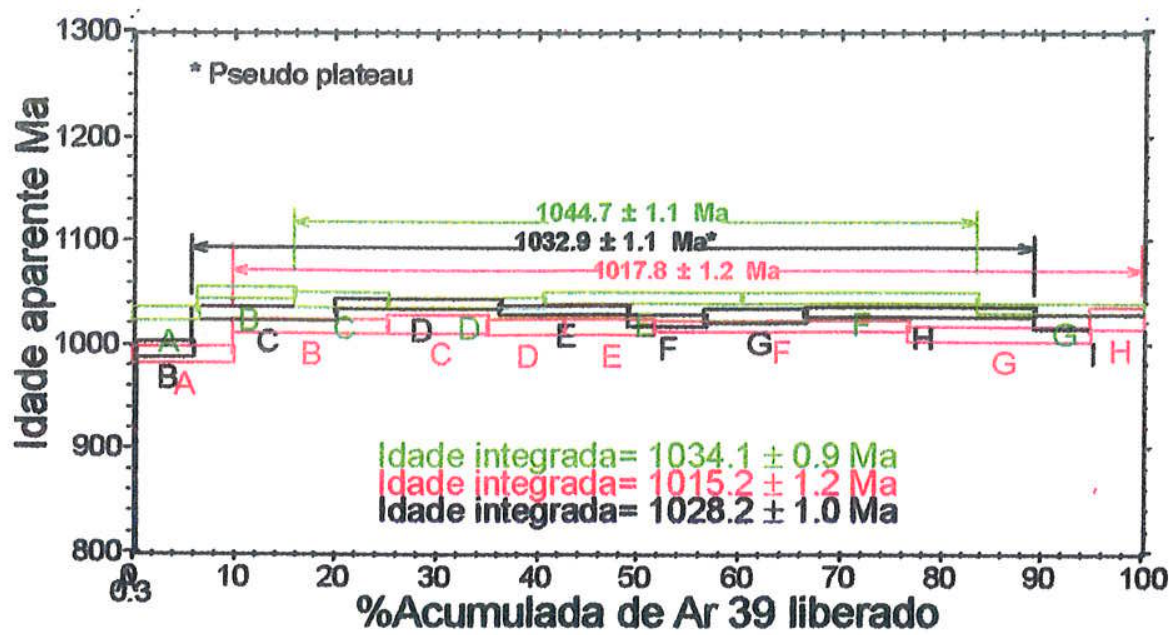

FIGURA 54 - Espectro de degaseificação da biotita, amostra C-271

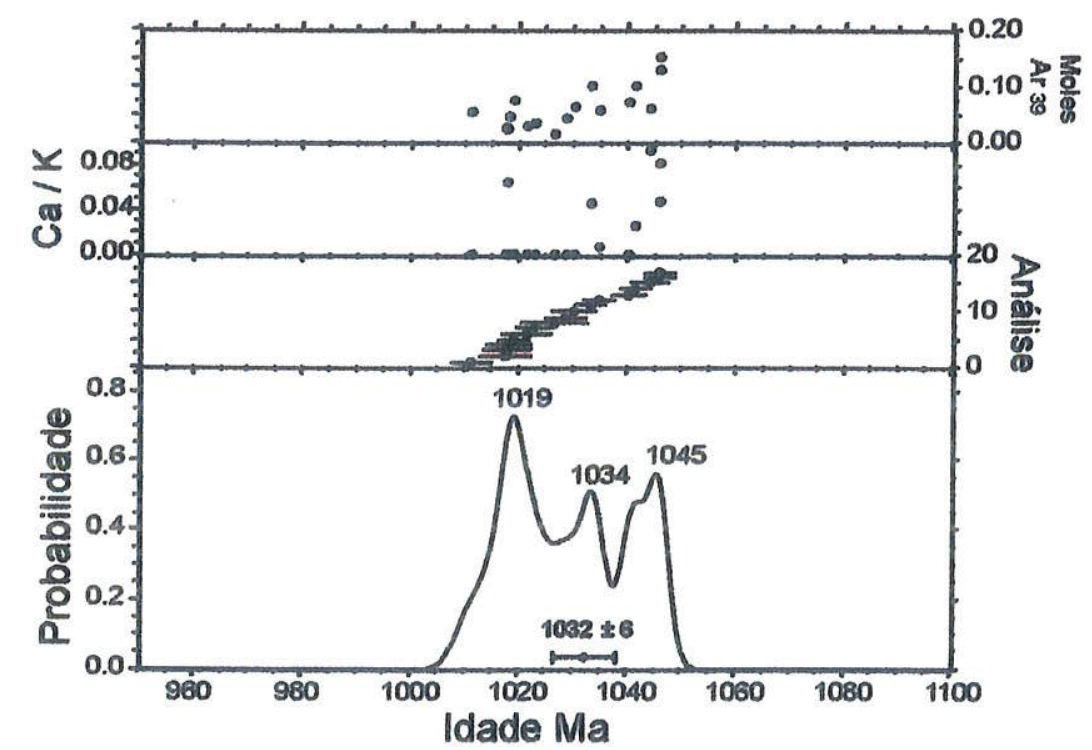

FIGURA 55 - Ideograma para os grãos da biotita, amostra C-271

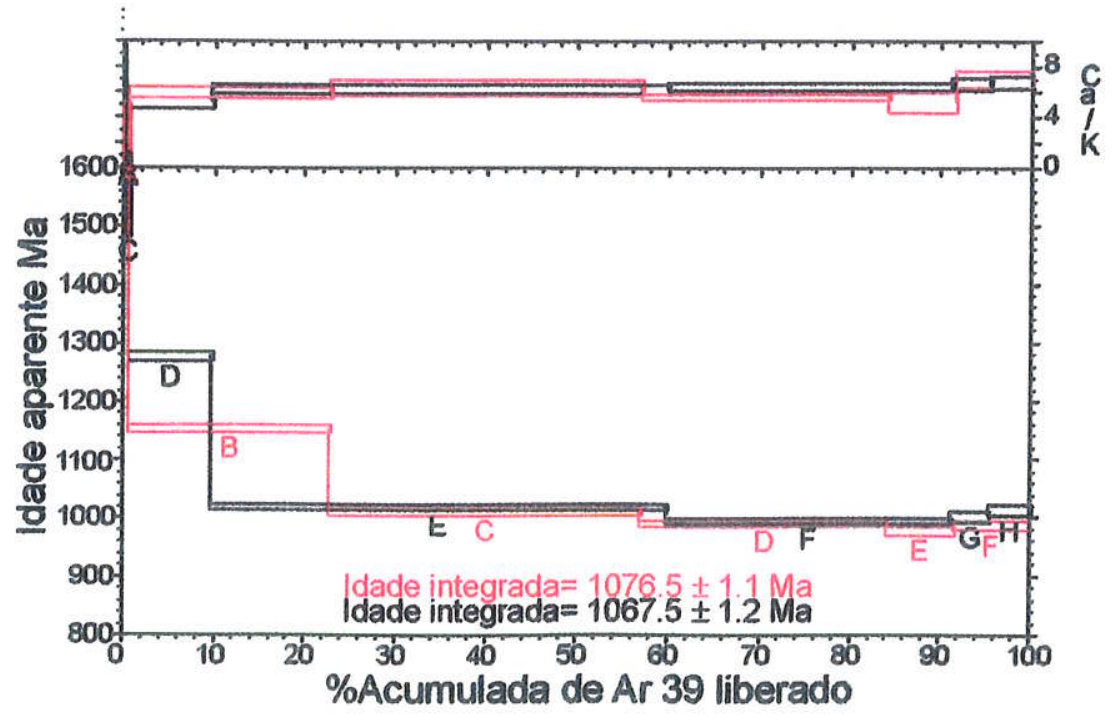

FIGURA 56 - Espectro de degaseificação da hornblenda, amostra C-299 


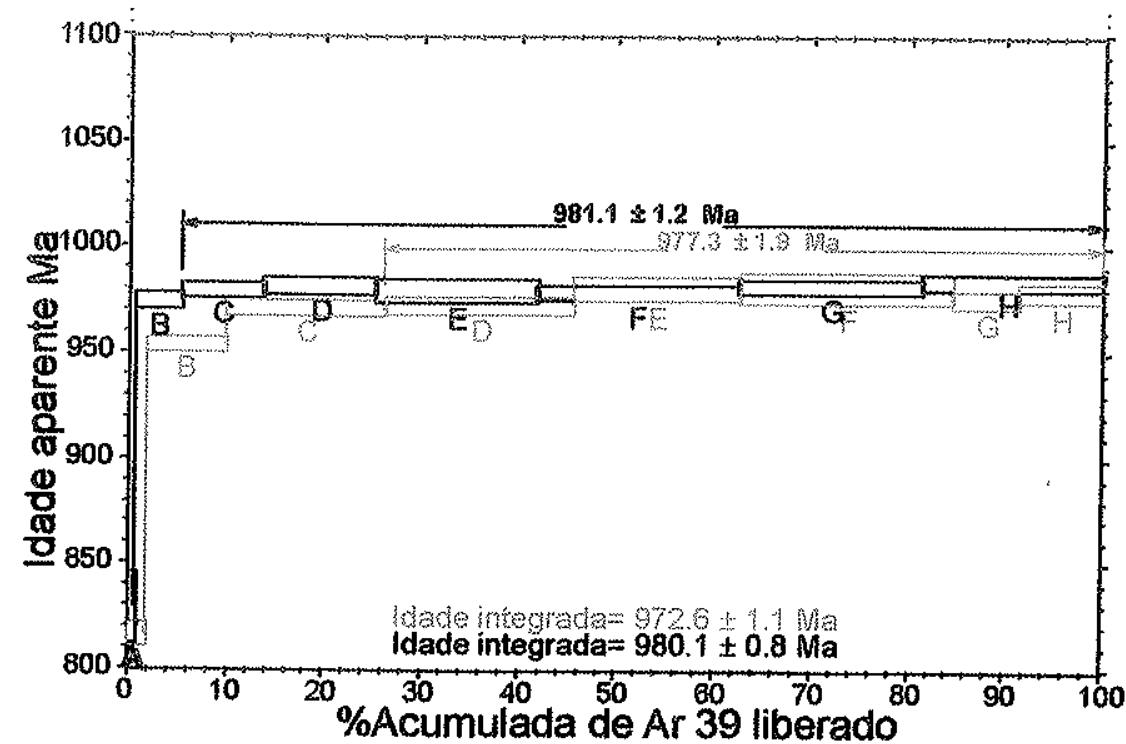

FIGURA 57 - Espectro de degaseificação da biotita, amostra C-299

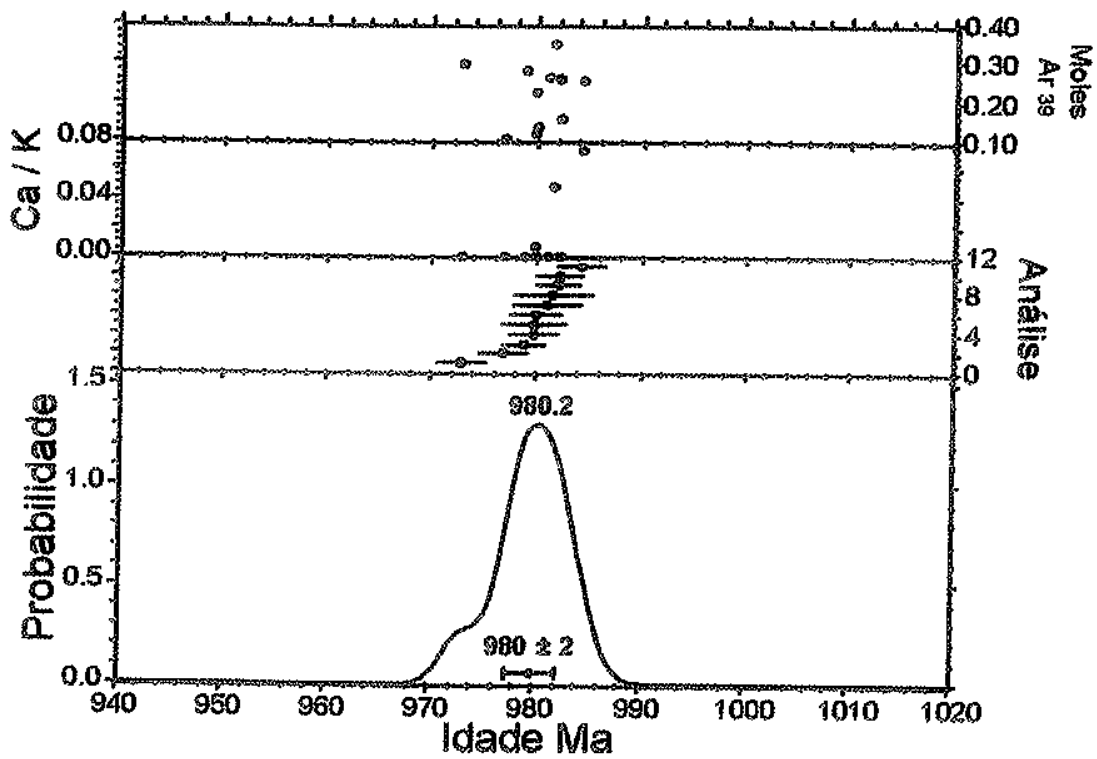

FIGURA 58 - Ideograma para os gräos da biotita, amostra C-299

As idades aparentes ao redor de 1000 Ma obtidas em biotitas e hornblendas, para as amostras C-302, C-271 e C-299, interpretam se como o resfriamento abaixo $350^{\circ} \mathrm{C}$ do evento metamórfico ao qual é atribuida idade aproximada de 1034 Ma (isocrona Sm-Nd em RTgranada), obtida na amostra Gr-15p do Gnaisse das Margaritas.

Os dois grãos analisados da homblenda do granulito máfico (amostra C-32) apresentam espectros com aigum excesso de ${ }^{40}$ Ar nas etapas iniciais. Um dos grãos define um plateau de 982 + 1.6 Ma com o $67 \%$ do gás liberado, e outro grão têm idades aparentes similares, formando um pseudoplateau de 985 + $3 \mathrm{Ma}$ (FIGURA 59). A idade média calculada é de 984 t 
$3 \mathrm{Ma}$ (FIGURA 60), interpretada como indicando o resfriamento do evento metamórfico de alto grau. Nesta rocha foram também analisados dois grãos de biotita desenvolvidos durante a segunda foliação, que afetou as bandas granuliticas constituídas por granada, hornblenda, biotita, ortopiroxênio e plagioclásio (PRANCHA 3, Fotos 7 e 8). Ambos exibem espectros homogêneos com plateaus de 954 e $948 \mathrm{Ma}$ com até $98 \%$ do gás liberado (FIGURA 61). A idade média obtida é de $951 \pm 3$ Ma (FIGURA 62).

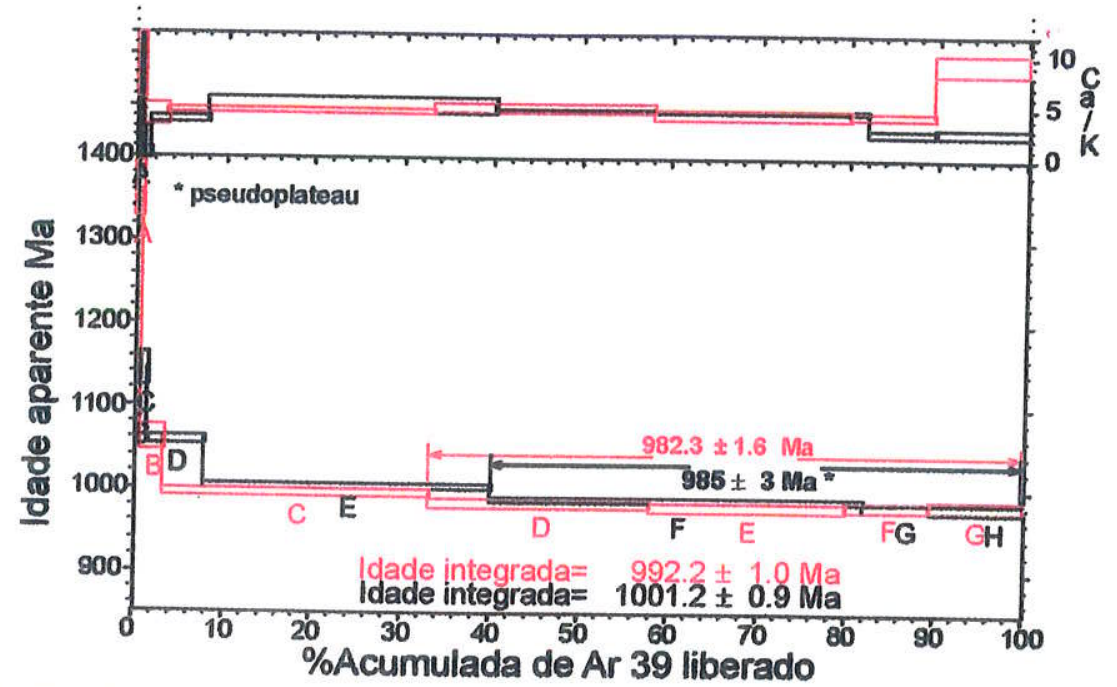

FIGURA 59 - Espectro de degaseificação da hornblenda, amostra C-32

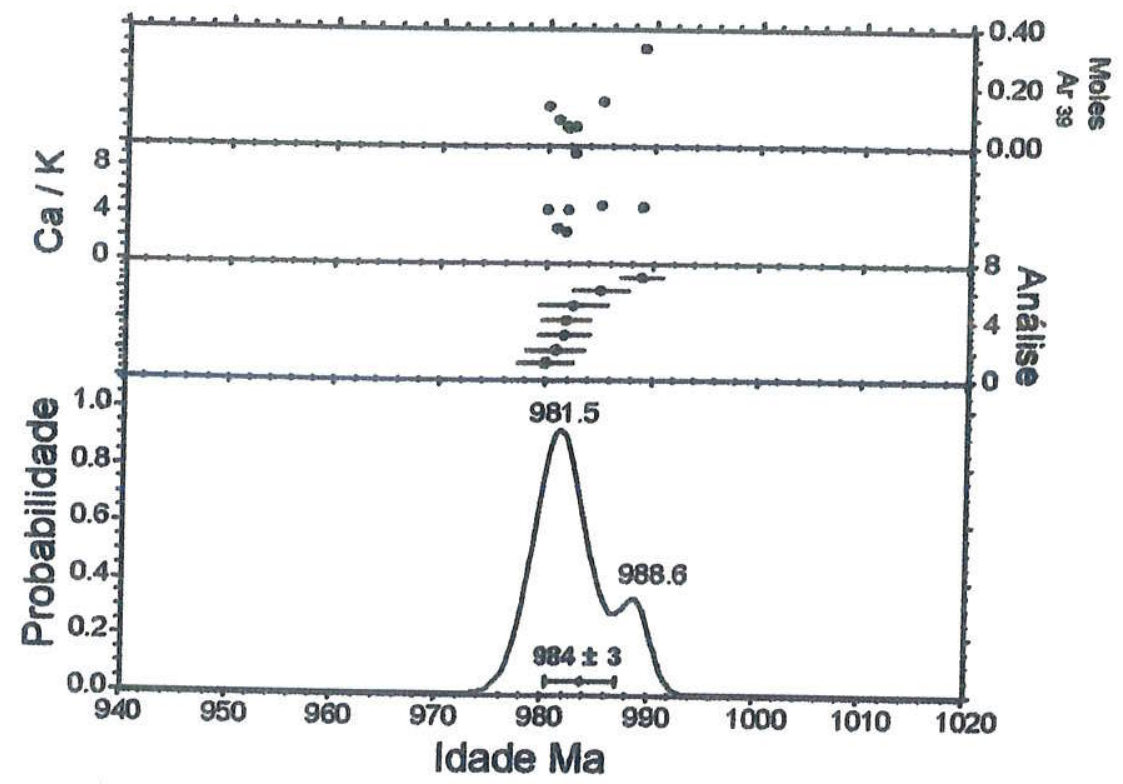

FIGURA 60 - Ideograma para os grãos da hornblenda, amostra C-32

Três grãos de biotita do biotita gnaisse $\mathrm{Gr}$-15p fornecem espectros com plateaus de 962, 964 e $974 \mathrm{Ma}$, e perdas de argônio nas primeiras etapas de degaseificação (FIGURA 63). A idade média obtida é de $967 \pm 3$ Ma (FIGURA 64). 


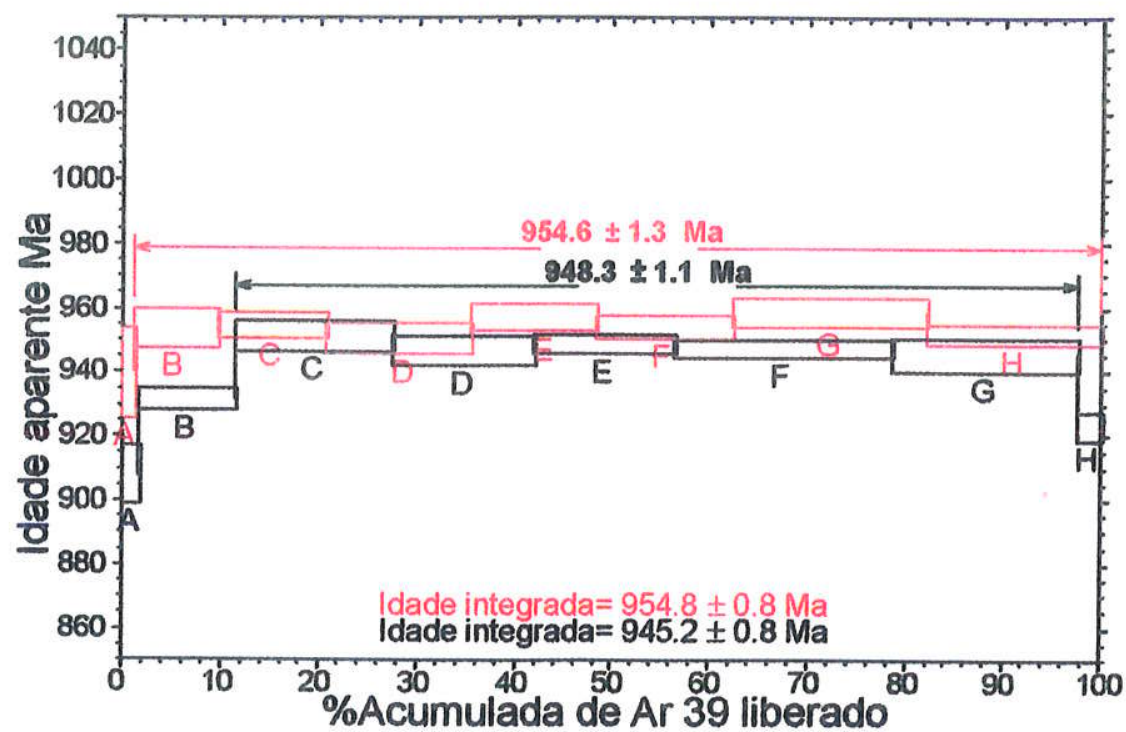

FIGURA 61 - Espectro de degaseificação da biotita, amostra C-32

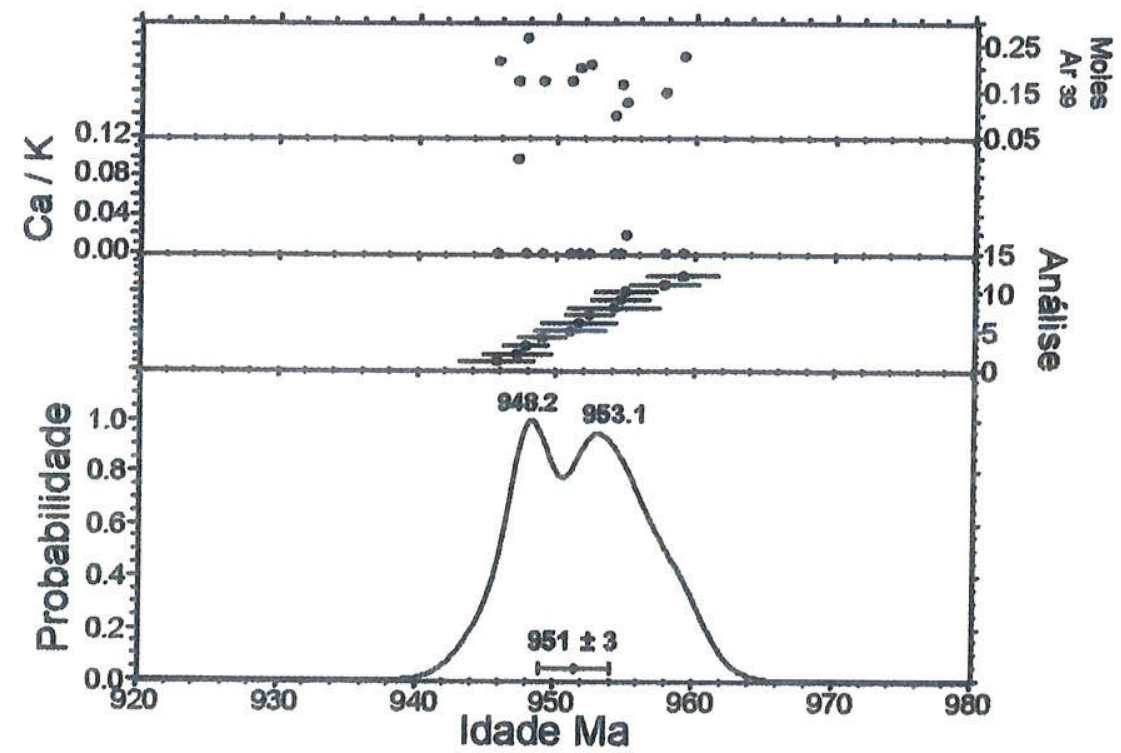

FIGURA 62 - Ideograma para os grãos da biotita, amostra C-32

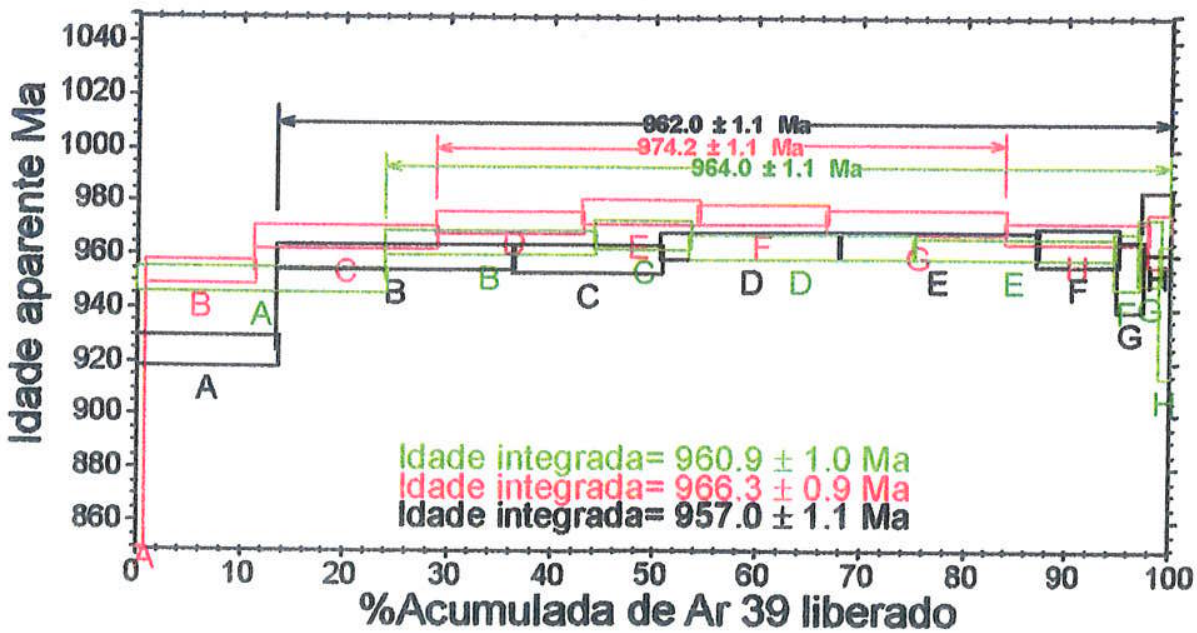

FIGURA 63 - Espectro de degaseificação da biotita, amostra Gr-15p 


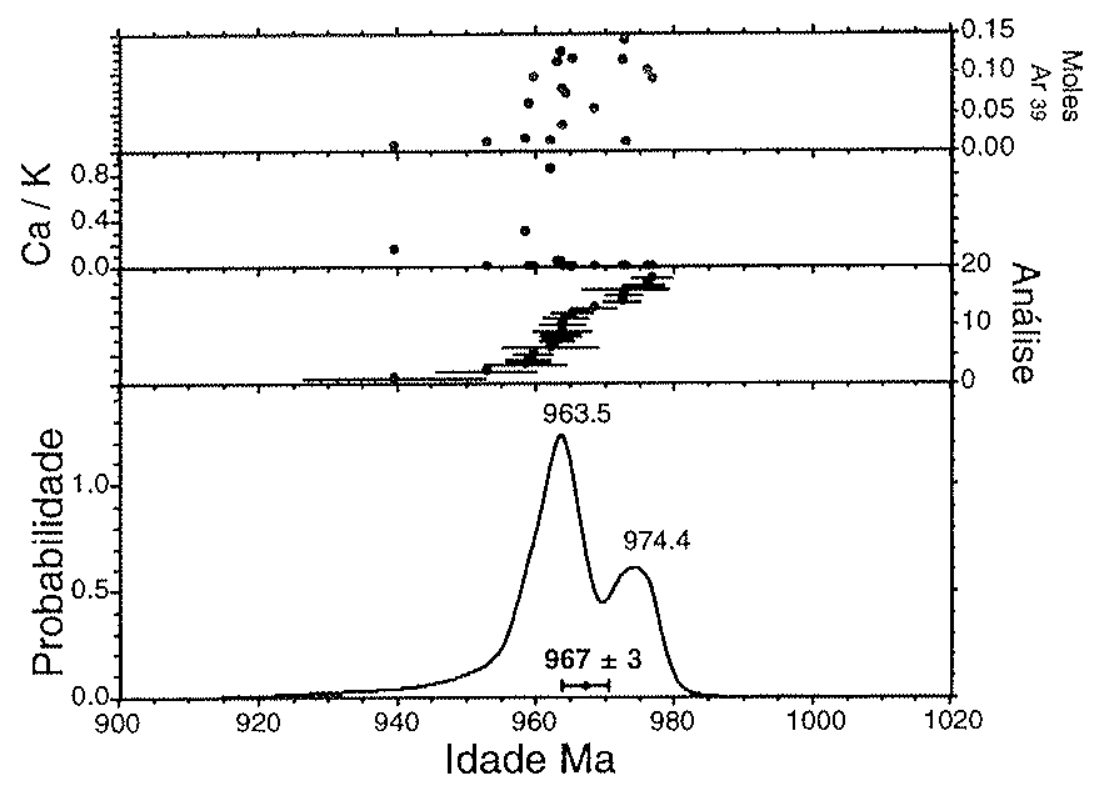

FIGURA 64 - Ideograma para os grãos da biotita, amostra Gr-15p

As idades aparentes das biotitas das amostras C-32 e Gr-15p, ao redor de $960 \mathrm{Ma}$, são mais jovens do que aquelas atribuídas ao resfriamento metamórfico por volta de $1000 \mathrm{Ma}$ das amostras C-302, C-271 e C-299. Isto se explicaria pelo aquecimento provocado por deformação com possivel hidrotermalismo associado, afetando a $T_{f}$ das biotitas existentes, (VILLA, 1998), e levando em conta o aparecimento de biotitas neoformadas. Com efeito, na porção oriental desta unidade desenvolve-se a paragênese biotita+plagioclásio \pm sillimanita associada a uma segunda foliação, possivelmente relacionada com cisalhamento dúctil em condições de alto grau.

Os dados Ar-Ar evidenciam histórias térmicas diferentes para os dois domínios do Maciço de Garzón (Granulitos do Vergel e Gnaisse das Margaritas), que possivelmente pertencem a blocos tectônicos separados. Com efeito as idades ideograma obtidas para as biotitas da porção ocidental do maciço resultam em torno de $915 \mathrm{Ma}$, em quanto que as idades das biotitas e hornblendas da porção oriental são de cerca de $1000 \mathrm{Ma}$.

Do Complexo Migmatitico da Cocha Rio Tellez foram analisadas hornblendas e biotitas de um granodiorito gnáissico (A-746) cuja idade de cristalização é de $166 \pm 4 \mathrm{Ma}$ (FIGURA 29). Dois grãos de hornblenda apresentam espectros similares, com algumas evidências de excesso de argônio 40 nas primeiras e últimas etapas. Um dos grãos fornece uma idade plateau de $36.4 \pm$ 0.6 Ma nas etapas intermediarias (FIGURA 65); entretanto, este valor pode não ter significado geológico tendo em vista a presença de argônio em excesso no sistema isotópico deste mineral. 


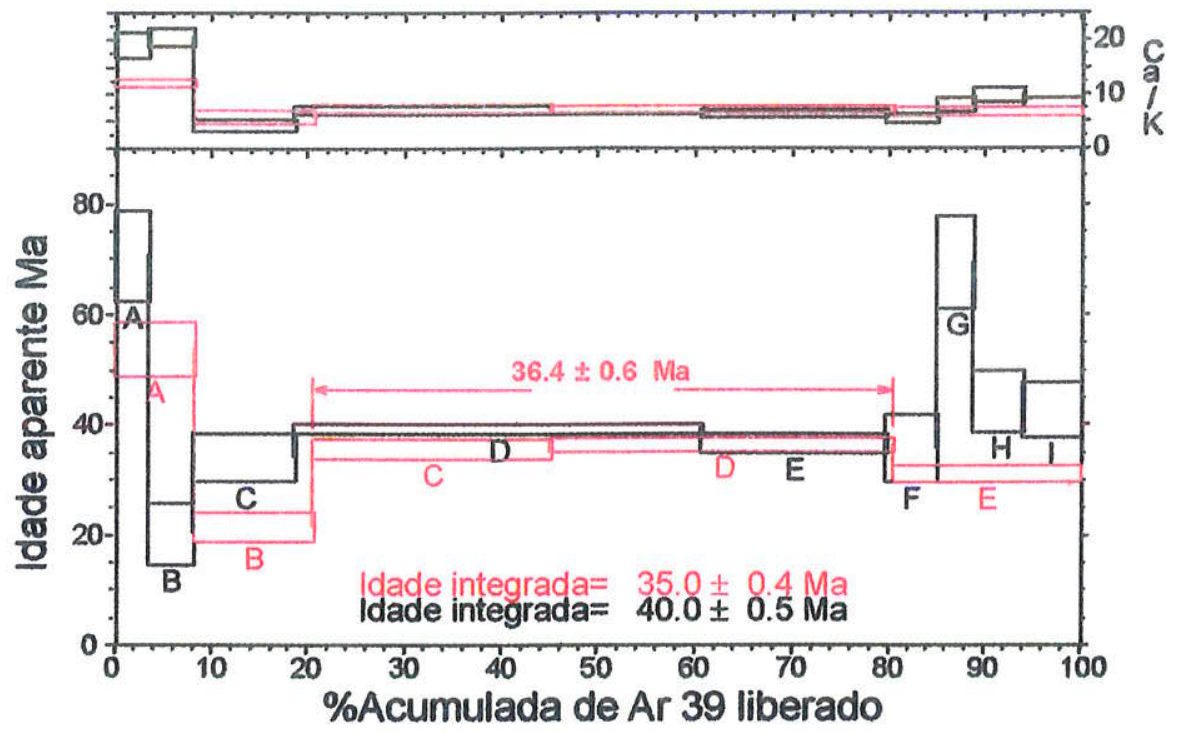

FIGURA 65 - Espectro de degaseificação da hornblenda, amostra A-746

Dos três grãos de biotita analisados desta amostra, dois apresentam espectros que fornecem idades plateau por volta de $22 \mathrm{Ma}$, e o outro grão apresenta um pseudoplateau, com idade aparente similar (FIGURA 66). A idade média ponderada dos steps que definem plateau e pseudoplateau é de $22.4 \pm 0.4 \mathrm{Ma}$ (FIGURA 67). Este valor é interpretado como o resfriamento de um evento térmico regionalmente importante possivelmente associado com a intrusão do Pluton dos Alisales de idade Oligocena (ASPDEN ot al., 1987), localizado nas proximidades de Monopamba.

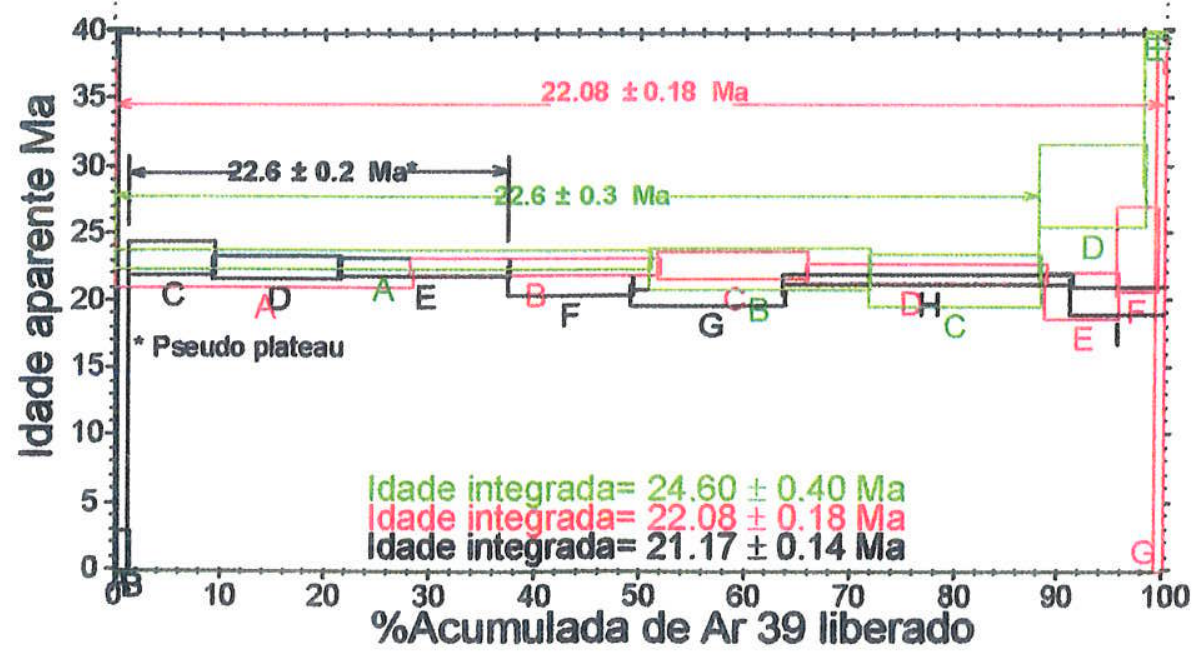

FIGURA 66 - Espectro de degaseificação da biotita, amostra A-746

A idade da colocação do granito gnáissico de $166 \pm 4$ Ma (U-Pb SHRIMP em zircão) e as idades aparentes Ar-Ar em biotita claramente confirmam que o Complexo Migmatítico da Cocha Rio Tellez nada tem a vez com a evolução proterozóica do Maciço de Garzón 


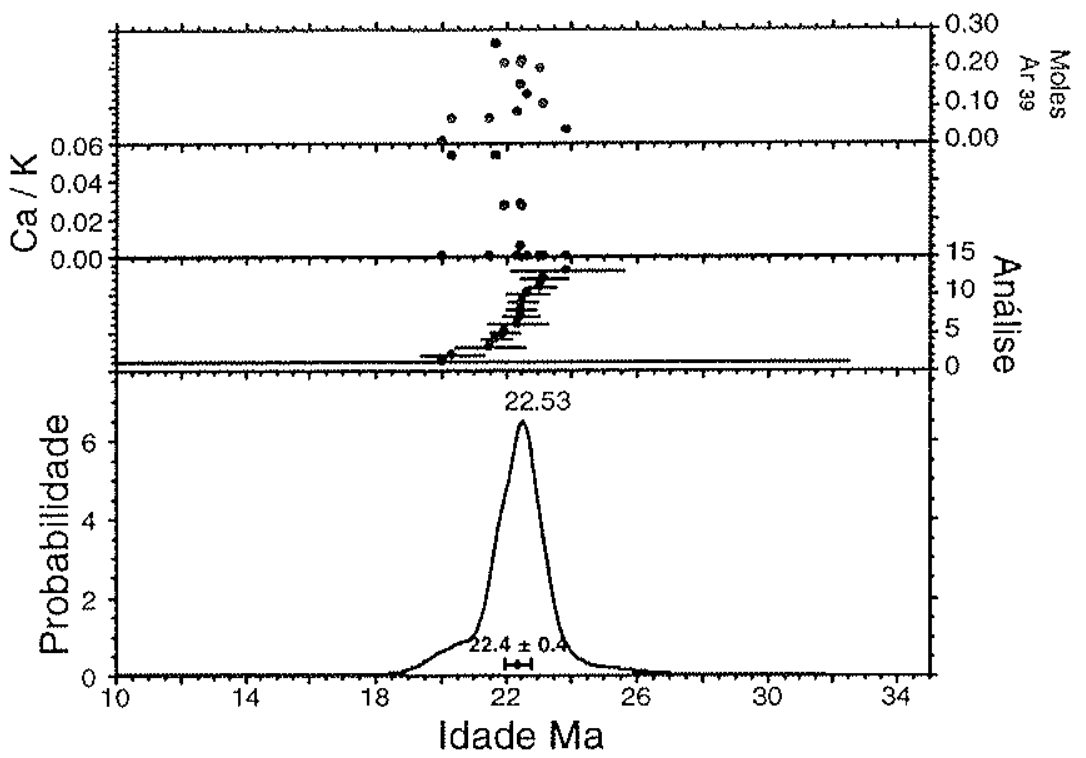

FIGURA 67 - Ideograma para os grãos da biotita, amostra A-746 


\section{CARACTERIZAÇĀO GEOTECTÓNICA DO MACIÇO DE GARZÓN}

\subsection{Evolução tectono-metamórfica}

A integração conjunta da geologia, condições metamórficas P-T e o contraste de tempo no qual os processos aconteceram permitem reconstruir a seqüência de eventos tectonometamórficos regionais e desta forma determinar a evolução geológica do Maciço de Garzón, a qual esta compilada no QUADRO 9.

O metamorfismo principal que afetou à seqüência de rochas ígneas e metamórficas do Maciço de Garzón (unidades Gnaisse de Guapotón-Mancagua, Granulitos do Vergel e Gnaisse das Margaritas) é do tipo regional prógrado, na transição de fácies anfibolito superior a granulito. As rochas de mais alto grau localizam-se na porção oeste e as de menor grau na porção leste. Esta distribuição pode estar perturbada, e incluir porções invertidas da crosta superior a média, por causa da atividade tectônicas sucessivas.

As condições de pressão e temperatura prevalescentes na faixa de transição metamórfica permitiram a existência de fases minerais hidratadas como biotita e homblenda, e adicionalmente favoreceram fusão parcial das rochas, especialmente aquelas com protolitos férteis. Isto pode ser constatado nas texturas migmatíticas, onde se reconhecem porçöes de rocha que pertencem a leucossomas e a paleossomas, respectivamente. O metamorfismo é do tipo Barrowiano de pressão média, que gerou nas rochas textura granoblástica e gnáissica, e caracterizou-se por desenvolvimento de sillimanita como único polimorfo de Al nas rochas mais pelíticas. Ocorrem também ortoclásio pertítico a mesopertítico, plagioclásio antipertítico nas associações ácidas, piroxênio, hornblenda e granada nas rochas máficas. Este último mineral é poikiloblástico, com inclusões arredondadas de quartzo, típicas de metamorfismo prógrado.

O metamorfismo prógrado na transição da fácies anfibolito-granulito, com idade mínima de $1034 \mathrm{Ma}$ obtida para o gnaisse biotítico Gr-15p (isócrona Sm/Nd RT-granada), faz parte de um cinturão metamórfico que pode ter sido gerado pelo espessamento crustal inerente a um processo de subducção do tipo B. Neste ambiente tectônico formou-se possivelmente um cinturão orogênico do tipo Andino, como foi previamente concebido por Kroonenberg (1982), e como indica a mistura de materiais juvenís e mais antigos no registro isotópico de Nd das rochas. O underthrusting da placa oceânica sob a porção continental acarretou um arco magmático na margem continental, e uma parte deste arco corresponderia ao Gnaisse de 
QUADRO 9. RESUMO DOS EVENTOS TECTONO-MAGMÁTICOS RECONHECIDOS NO MACICOO DE GARZÓN NESTA PESQUISA

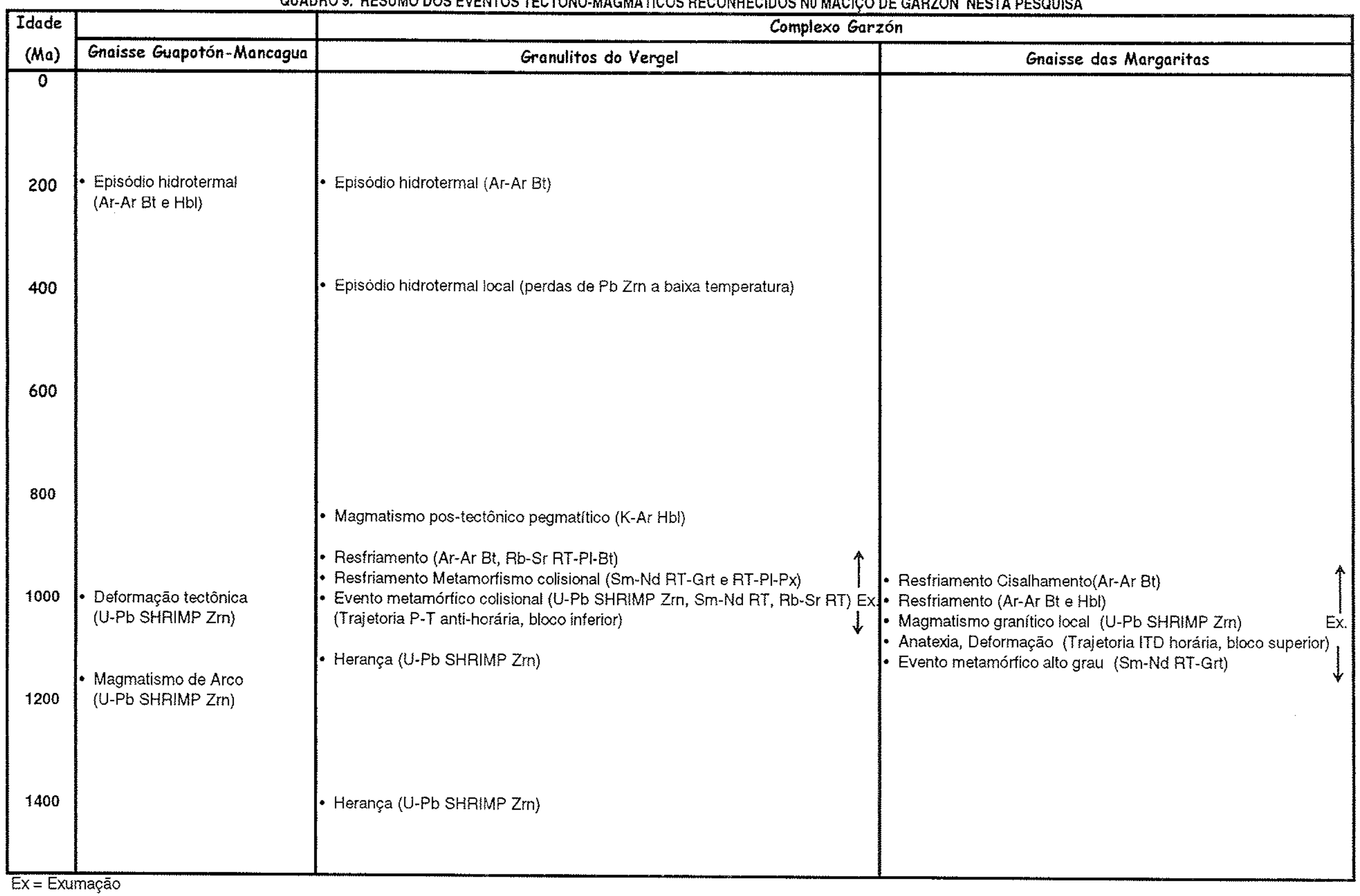


Guapotón-Mancagua formado há cerca de $1140 \mathrm{Ma}$ (idade U-Pb em zircão do núcleo magmático do ortognaisse V-198).

O espessamento crustal levou o material a aproximadamente $8 \mathrm{Kbar}$ e $780^{\circ} \mathrm{C}$. As temperaturas elevadas atingidas por esta porção do orógeno seriam devidas à importante fonte de calor interno relacionado com os granitóides do arco continental.

O caminho ITD obtido para o Gnaisse das Margaritas corresponde à trajetória de retrometamorfismo a partir das condições de metamorfismo na transição anfibolito-granulito. A história prógrada do metamorfismo não deixou evidências, visto que a alta taxa de difusão catiônica dos minerais evitou a preservação de um zoneamento composicional que permitisse revelar a história completa. Com toda probabilidade, a trajetória de descompressão aproximadamente isotérmica observada corresponde à parte final de um metamorfismo com caminho em sentido horário, no qual o pico bárico antecede o pico térmico. Como foi verificado no capítulo 4 (FIGURA 21), a trajetória está definida por quatro áreas no espaço P-T: 6.3-8.0 kbar e 780-826 ${ }^{\circ} \mathrm{C}$ (associação de equilíbrio do gnaisse biotítico), 7.7-8.1 kbar e 751$778{ }^{\circ} \mathrm{C}$ (associação de equilibrio do granulito máfico), 6.8-7.9 kbar e 688-752 ${ }^{\circ} \mathrm{C}$ (associação em desequilíbrio do granulito máfico), e < 4 kbar a $630^{\circ} \mathrm{C}$ (simplectitas de biotita verde e plagioclásio substituindo granada em quartzo-plagioclasio gnaisse).

Após o evento tectono-metamórfico que gerou as condições máximas de pressão e temperatura, as rochas pelíticas sofreram descompressão possibilitando a sua fusão parcial, cuja evolução final anidra culminou com a quebra da biotita, levando à cristalização de granada nos leucossomas. As condições de temperatura não foram suficientes para permitir a fusão da hornblenda dos anfibolitos boudinados, associados à seqüencia pelítica, ou seja, estes corpos comportaram-se como paleossomas com relação ao evento de fusão parcial.

Ambiente tectônicos de subducção-B terminam normalmente numa colisão final, acompanhada do fechamento da bacia oceânica envolvida (WINDLEY, 1995; CONDIE, 1997). No presente caso, o choque de outra placa continental ou terreno alóctone, com a margem continental do tipo andino previamente deformada, acarretou metamorfismo superimposto no ortognaisse (Gnaisse de Guapotón-Mancagua), com formação de borda de zircões metamórficos de 1000 Ma ao redor do precursor de origem ígnea. Simultaneamente, a tal colisão favoreceu no Gnaisse das Margaritas a retomada dos esforços compressivos, com o desenvolvimento de uma segunda foliação mineral de biotita, plagioclásio e as vezes sillimanita nos gnaisses migmatíticos e nos granulitos. Este evento apresenta resfriamento regional por volta de 951 
Ma (Ar-Ar em biotita da segunda foliação na amostra C-32). Associada à retomada de esforços, houve fusão parcial e migração de fluidos, originando leucossomas graníticos que injetaram-se na seqüência original ao redor de $1006 \mathrm{Ma}$ (U-Pb em zircão da amostra Gr-15A).

O evento de migmatização, com geração de leucossomas quartzo-feldspáticos com granada, ocorreu entre 1034 e $1006 \mathrm{Ma}$; o primeiro valor representa a idade mínima do metamorfismo na transição anfibolito-granulito, no qual se formaram os biotita gnaisses (paleossoma); o segundo seria indicativo da cristalização do leucossoma de injeção.

Como resposta aos esforços compressivos atuantes, desencadearam-se movimentos crustais entre os dois blocos do orógeno (Granulitos do Vergel e Gnaisse das Margaritas), os quais deram-se através de empurrões, à maneira de escamas tectônicas, gerando duplicação da crosta. Os movimentos tectônicos foram reativados durante o Neogeno (VAN DER WIEL, 1991) com desenvolvimento de vários empurrões definidos nas cartas geológicas de Ingeominas \& Geoestudios, 2001 a,b, que apresentam vergência para leste. A relação definida entre os blocos, para o Meso-Neoproterozóico, por meio da geotermobarometria, sugere que os falhamentos antigos tinham vergência oposta àqueles reativados posteriormente, durante a fase tectônica Andina.

A trajetória anti-horária definida para os Granulitos do Vergel, a partir de amostra (V-332) localizada possivelmente na parede do bloco inferior, está representada por dois campos no diagrama P.T de $700^{\circ} \mathrm{C}-6 \mathrm{kbar}$ (associação em equilíbrio do granulito charnockítico) e 687$733^{\circ} \mathrm{C}$ - 6.2-7.0 kbar (associação em re-equilíbrio do granulito charnockítico) (FIGURA 9). Esta trajetória, que apresenta aumento de pressão e temperatura quase constante, é verificada pelo enriquecimento do componente grossulárico na granada almandínica na borda do cristal em contato com biotita. A idade de $934 \mathrm{Ma}$ (isócrona Sm/Nd Rt-granada) da amostra localizada no bloco abaixado, representa o re-equilíbrio do granulito charnockítico sob temperatura de $600^{\circ} \mathrm{C}$ como resposta ao movimento entre os blocos. De acordo com RIDLEY (1989) qualquer episódio de deformação tectônica num cinturão orogênico provoca movimentos crustais relativos de corpos de rochas que podem ser inferidos pela história metamórfica. Os tipos de caminhos P-Tut dependem de onde a rocha examinada movimentou-se no contexto do empilhamento orogênico. O bloco superior resfria logo após o movimento, enquanto que o bloco inferior pode sofrer novo aumento da temperatura após o movimento, que pode obliterar as evidências da história metamórfica inicial. 
As idades geocronológicas por volta de $1000 \mathrm{Ma}$ (U-Pb SHRIMP em zircão), $959 \mathrm{Ma}$ (Rb-Sr em RT), $930 \mathrm{Ma}$ (Sm-Nd RT-granada e RT-mineral), e $923 \mathrm{Ma}$ (Rb-Sr RT-mineral), confirmam o re-equilibrio metamórfico de alto grau (T de $700^{\circ} \mathrm{C}$ e $P$ de $6 \mathrm{Kbar}$ ) dos Granulitos do Vergel após a colisão, contemporâneo com as fases de migmatização, magmatismo e cisalhamento desenvolvidas nos Gnaisses das Margaritas.

A presença de trajetórias em sentido horário e anti-horário em terrenos granulíticos é bem conhecida no mundo todo. O fato de encontrar estos dois tipos de caminho no Maciço de Garzón, bem como os elementos asincrônicos da história metamórfica para as duas unidades do Complexo Garzón, permitem sugerir deslocamentos verticais internos entre os blocos por volta de 950 - $1000 \mathrm{Ma}$, já que não foram encontradas evidências (por ex. zonas dúcteis, ou diferenças de litologia ou de geoquímica isotópica) que indiquem existência de dois terrenos diferentes.

Uma única zona de cisalhamento dúctil que separe as duas unidades não tem sido identificada. Entretanto, sua existência não pode ser descartada, já que localmente este tipo de tectônica foi constatado, principalmente afetando o Gnaisse das Margaritas, onde foram assinalados inúmeros falhamentos de empurrão (Ingeominas \& Geostudios). Segundo VAN DER PLUIJM et al. (1994) as principais suturas podem ser menos proeminentes do que as menores e melhor preservadas zonas de cisalhamento mais jovens que geram escamas tectônicas.

As idades Ar-Ar em biotitas e anfibólios das rochas regionais do Maciço de Garzón representam o resfriamento do evento metamórfico de alto grau para o Gnaisse das Margaritas, com valores de aproximadamente $1000 \mathrm{Ma}$ para a hornblenda e biotita. Para os Granulitos do Vergel os valores são de aproximadamente $925 \mathrm{Ma}$ em hornblenda e $915 \mathrm{Ma}$ em biotita (ALVAREZ \& LINARES, 1985; VAN DER WIEL, 1991) e confirmam o re-equilíbrio com aquecimento posterior desta parte do orógeno, como resposta à colisão continental.

Pegmatitos cortam todas as unidades do Maciço Garzón e representam os eventos terminais da orogênese. PRIEM et al. (1989) dataram um pegmatito nos Granulitos do Vergel com idade $\mathrm{Rb}-\mathrm{Sr}$ de $847 \mathrm{Ma}$.

Após ter acontecido considerável descompressão no Gnaisse das Margaritas e subseqüente movimento crustal dos Granulitos do Vergel, com taxas de exumação em torno de $3^{\circ} \mathrm{C} / \mathrm{Ma}$, a descompressão prosseguiu em porçōes mais rasas da crosta (partes de mais baixa pressão da 
trajetória (TD). O sistema pode então cruzar o sólidus saturado em água, quando são formados fundidos graníticos (THOMPSON, 2001). Este cenário pode indicar que os caminhos P-T e T-t passaram a baixas profundidades e os magmas gerados permaneceram quentes ao mesmo tempo que a exumação foi rápida, permitindo a sua mobilidade (THOMPSON, 2001).

A identificação de terrenos tectônicos justapostos, em regiões metamórficas de alto grau, poderia idealmente obter-se através da determinação das trajetórias P-T-t quantitativas para o tempo entre a sedimentação e exumação; entretanto isto é praticamente impossível, já que na maioria das vezes a história prógrada do metamorfismo não pode ser verificada (VAN DER PLUIJM et al., 1994). Uma tentativa alterna é construir para cada unidade um diagrama T-t com base nas idades aparentes $\mathrm{Rb}-\mathrm{Sr}$, Sm-Nd, e Ar-Ar para comparação da evolução térmica de blocos vizinhos (FIGURAS 68 e 69).

A integração dos resultados termocronológicos ilustrados na figura 68 , sugere que a história térmica dos Granulitos do Vergel é caracterizada por um resfriamento descontínuo. Após o metamorfismo, durante longo tempo, os granulitos resfriaram lentamente $\left(2.8{ }^{\circ} \mathrm{C} / \mathrm{Ma}\right)$, sucedendo-se um período de resfriamento bastante rápido $\left(23^{\circ} \mathrm{C} / \mathrm{Ma}\right)$, refletindo maior eficiência no processo de exumação. Já a historia térmica do Gnaisse das Margaritas (FIGURA 69) caracterizou-se por um resfriamento mais regular, visto que após o metamorfismo de alto grau, o resfriamento aconteceu continuamente com taxas de aproximadamente $3.5^{\circ} \mathrm{C} / \mathrm{Ma}$.

Caminhos $T$-t não paralelos de domínios próximos podem refletir separação espacial (terrenos diferentes) ou deslocamento vertical interno (VAN DER PLUIJM et al., 1994). Consideramos menos provável a primeira interpretação, já que os dados isotópicos Sm-Nd são similares, para as duas unidades, com valores de $\mathrm{T}_{\mathrm{DM}}$ entre 1.4 e $2.0 \mathrm{Ga}$. As trajetórias P-T-t e T-t parecem indicar deslocamento vertical interno, com diferença no tempo e na pressão, refletindo diferentes níveis crustais para os Granulitos do Vergel e o Gnaisse das Margaritas.

Para o Meso-Cenozóico, a evolução tectônica dos Andes caracterizou-se pela geração de sucessivos arcos magmáticos como resposta à subducção da litosfera oceânica por baixo da margem continental da América do Sul (ASPDEN et al., 1987). Por outro lado, os dados geocronológicos obtidos nas rochas do Maciço de Garzón refletem apenas os acontecimentos do Proterozóico. Conseqüentemente, as rochas estudadas desse maciço não foram perturbadas termalmente por 


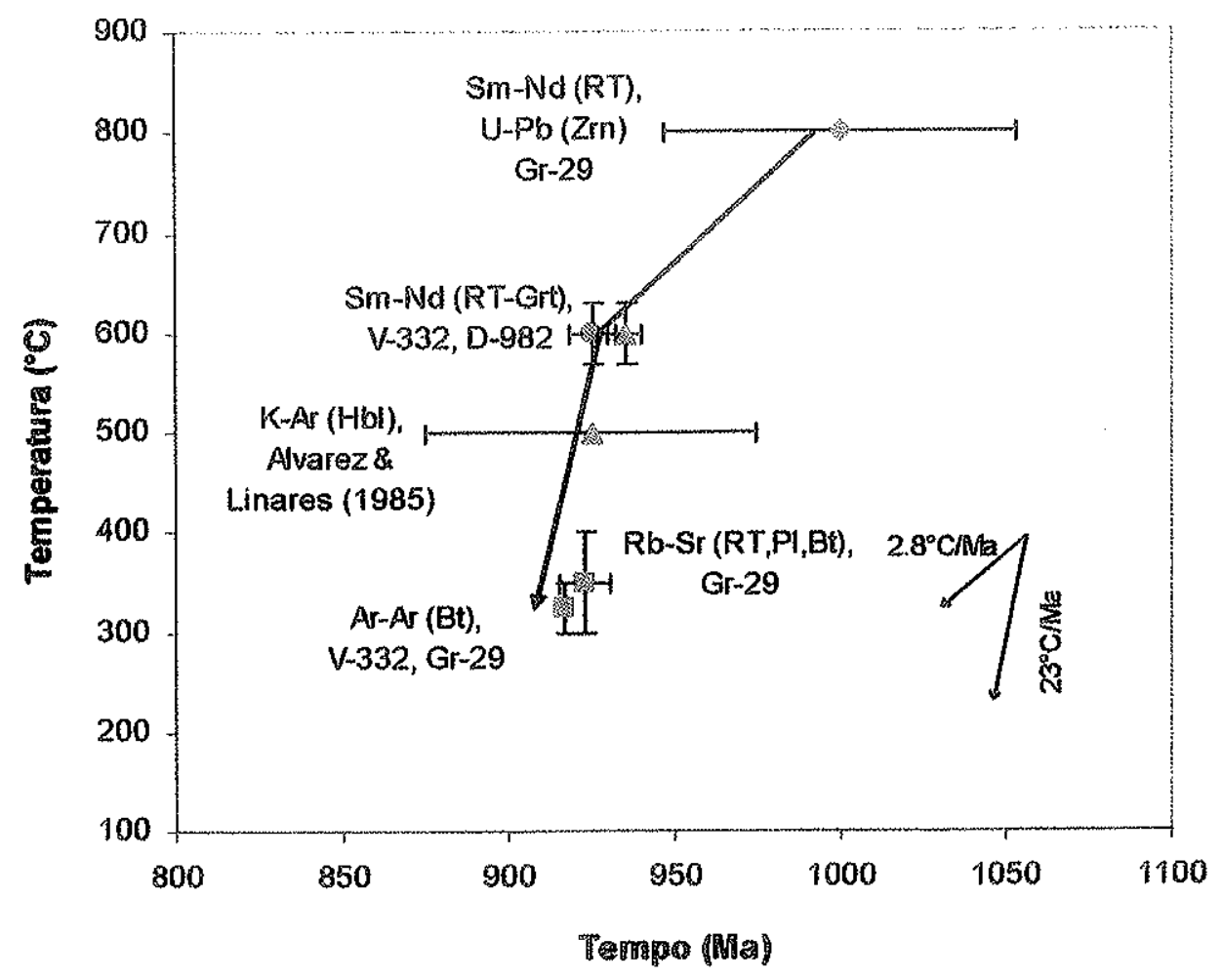

FIGURA 68 - Diagrama T-8 para os Granulitos do Vergel

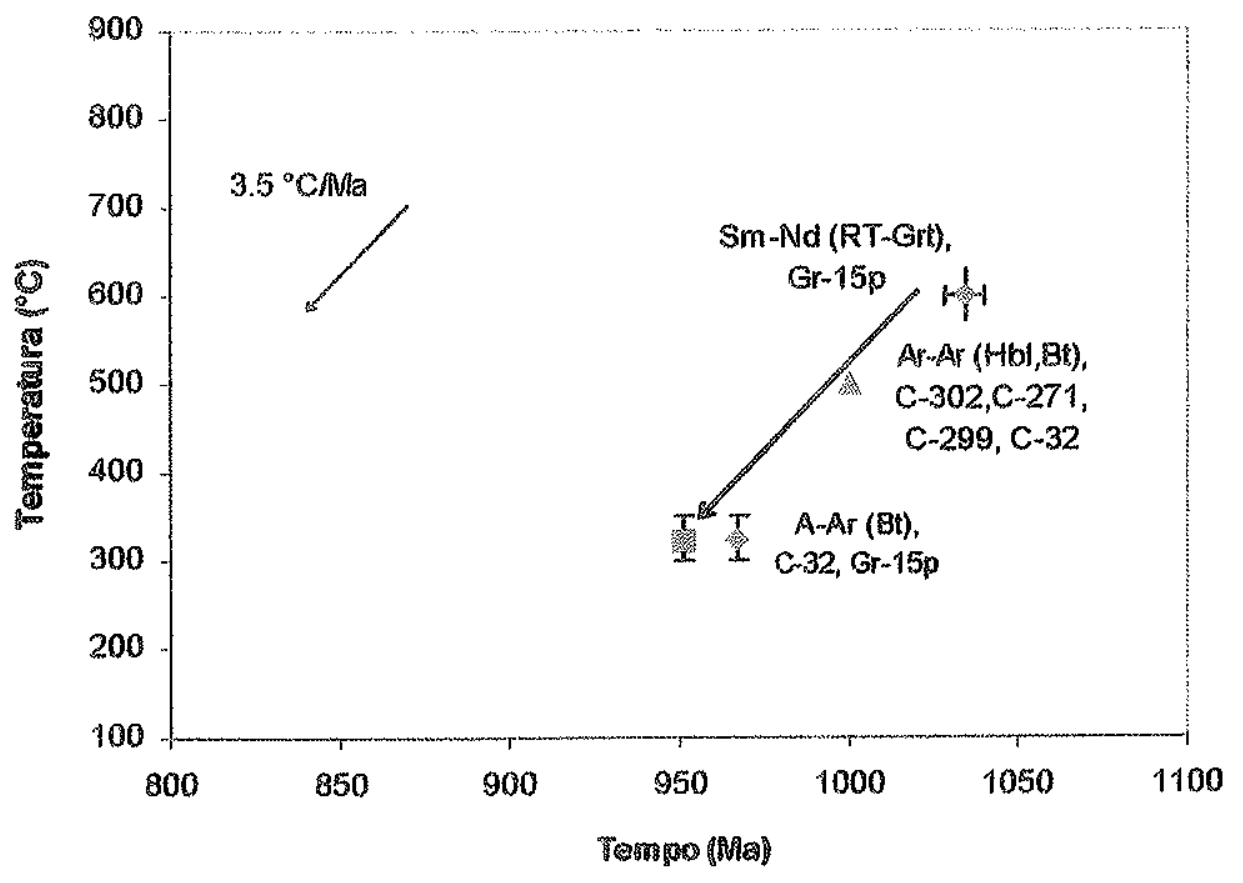

FIGURA 69 - Diagrama T"B́ para a Onaisse das Margaritas. 
intrusões Andinas de stocks e batólitos cálcio-alcalinos, e rejuvenescimento causado por magmatismo de arco no Mesozóico parece que ocorreu apenas localmente na borda oeste do maciço no Gnaisse de Guapotón-Mancagua (RESTREPO-PACE, 1995). Isto demostra que, para o Jurássico, não houve no Maciço de Garzón aquecimento regional com rejuvenescimento isotópico dos sistemas $\mathrm{K}-\mathrm{Ar}$ e $\mathrm{Ar}$-Ar, diferentemente do que ocorreu no embasamento dos maciços da Sierra Nevada de Santa Marta, Santander e Guajira, fortemente afetados e segmentados durante o Jurássico (CARDONA, 2003). O Maciço de Garzón permaneceu livre da influência desse evento tectono-magmático, e a história térmica Andina seguramente no chegou a produzir temperaturas regionais superiores a $300^{\circ} \mathrm{C}$.

Por outro lado, ao sudoeste do Maciço de Garzón, o gnaisse localizado nas proximidades do vilarejo de Monopamba, e pertencente ao Complexo Migmatítico da Cocha Rio Tellez, com idade sin-tectônica em torno de $166 \mathrm{Ma}$ (U-Pb SHRIMP em zircão), foi afetado por um evento magmático local, possivelmente, do Oligoceno, que produziu aquecimento significativo e rejuvenescimento isotópico do sistema Ar-Ar.

\subsection{Correlações regionais e participação na formação do supercontinente de Rodinia}

Toussaint (1993) considerou o domínio do embasamento de Garzón como um possivel terreno suspeito, amalgamado à região cratónica amazônica durante a colisão continental que gerou o metamorfismode alto grau. Sua justificativa foi a comparação do estilo do metamorfismo e a deformação entre este domínio e a região cratónica amazônica, bem como em considerações globais de paleogeografia do Mesoproterozóico. Cabe lembrar que o evento deformacional que afetou as rochas do Craton Amazônico tem sido relacionado ao evento Nickeriense do Suriname e República de Guyana, caracterizado por desenvolvimento de zonas de cisalhamento e milonitização a $1100 \mathrm{Ma}$ (PRIEM et al., 1989). Por outro lado CARDONA (2003) considera que as diferenças no estilo de metamorfismo e deformação podem ser explicáveis por variaçōes laterais de fácies, com a paleomargem continental representando os domínios internos. As regiões cratônicas que corresponderiam ao antepaís, poderiam ter sofrido tectonismo reflexo da orogenia Meso-Neoproterozóica em sua margem ocidental.

As associações litológicas do embasamento de Garzón são semelhantes às de Santa Marta (KROONENBERG, 1982) e também às das outras exposições de embasamento dos Andes do Norte. Com efeito, as condições do metamorfismo, na transição do fácies anfibolito superior a granulito das rochas de Garzón, que equilibraram a pressões entre 6-8 Kbar, são similares às 
obtidas o Gnaisse de Dibuya, Gnaisse de Bucaramanga e Gnaisse de Jojoncito (CARDONA, 2003).

O registro cronológico do Maciço de Garzón permite diferenciar dois eventos tectonometamórficos por volta de $1035 \mathrm{Ma}$ e $1000 \mathrm{Ma}$. Este último episódio tem sido também claramente determinado nos domínios proterozóicos do Norte da Colômbia (RESTREPOPACE et al., 1997; ORDOÑEZ, 1997, 2001; CARDONA, 2003). Alem disto, as características isotópicas (idades modelo $\mathrm{Sm}-\mathrm{Nd} \mathrm{T}_{\mathrm{DM}}$ ), e os indicadores petrotectônicos de Sr e Nd tanto para os domínios do norte como do sul (Maciço de Garzón), refletem a presença de protolitos crustais com idades médias Meso a Paleoproterozóicas em todas as regiões estudadas, (dados desta pesquisa, RESTREPO-PACE et al., 1997, ORDONEZ, 2001, CARDONA, 2003). Tais características permitem sugerir a existência de processos geológicos semelhantes na evolução tectônica dessas unidades e em conseqüência uma correlação direta entre o embasamento de Garzón e os demais domínios proterozóicos dos Andes do Norte.

Temporalmente, os eventos orogênicos determinados para os domínios de embasamento colombianos do Proterozóico correlacionam-se também com os eventos tectono-termais Olmecan $1100 \mathrm{Ma}$ e Zapotecam $990 \mathrm{Ma}$, do complexo Oaxacan do Sul do México, definidos por SOLARI, et al. (2003). O domínio Oaxacan é considerado um microcontinente com uma evolução compatível à de um arco magmatico entre 1270-1140 Ma, sucedida por uma fase colisional (SOLARI et al., 2003 e referências inclusas). As características geocronológicas, o caráter metamórfico semelhante, e a presença de protolitos afins com geração de arco magmático, sugerem que todos esses domínios poderiam estar relacionados (RESTREPO-PACE et al., 1997; KEPPIE et al., 2003 e referências inclusas). Uma característica de Oaxaquia é a abundância de protolitos ígneos com assinaturas isotópicas (Nd e $\mathrm{Pb}$ ) que indicam uma mistura entre material juvenil do Meso-Neoproterozóico e mais antigo, com predomínio da porção juvenil. Em contraste, Garzón apresenta registro em parte juvenil, mais com maior aporte de material mais velho. A possivel configuração tectônica poderia ser a de um arco magmático no qual Oaxaquia ficaria no núcleo, e Garzón ficaria numa posição mais marginal e próxima ao continente, no caso, o Craton Amazônico.

As características isotópicas do $\mathrm{Pb}$ para o embasamento de Garzón sugerem afinidade com Oaxaquia (RUIZ et al., 1999) e com as províncias Rio Negro-Juruena e Rondônia-San Ignácio do Cráton Amazônico (TOSDAL \& BETTENCOURT, 1994; CARDONA, 2003). Adicionalmente, as análises U-Pb SHRIMP em zircão de várias amostras confirmam que os protolitos das rochas dos domínios dos Andes do Norte tinham afinidade com as províncias tectônicas do 
Craton Amazônico (CARDONA, 2003). Alem disto, as coberturas sedimentares do Paleozóico inferior apresentam particularidades idênticas às da região cratônica, com fósseis com clara afinidade Gondwânica na região da Macarena (RESTREPO-PACE, 1995), confirmando portanto que este domínio, no Cambriano, estaria situado na mesma bacia sedimentar. Pela afinidade acima mencionada, é provável que o magmatismo de arco e o metamorfismo de alto grau do Maciço de Garzón e de Oaxaquia poderia estar relacionado com os eventos orogênicos, que caracterizaram a margem continental do Craton Amazônico. Os dados apresentados aqui e aqueles obtidos por Cardona (2003) sugerem uma possivel configuração tectônica no Meso-Neoproterozóico, na qual o arco magmático de Garzón-Oaxaquia poderia estar localizado na margem ocidental do cráton, e possivelmente em sua porção setentrional.

Adicionalmente, nos Andes de Peru, Chile e Argentina têm sido identificada outra série de fragmentos cratônicos com registro tectono-metamórfico entre 1150 a $970 \mathrm{Ma}$ (RAMOS, 1988; WASTENEYS et al., 1995; TOSDAL, 1996; KAY et al., 1996), semelhantes em evolução temporal aos domínios proterozóicos dos Andes da Colômbia (Guajira, Santa Marta, Santander, e Garzón) e ao embasamento de México (Oaxaquia). O conjunto de todos estos fragmentos, localizados ao ocidente do Craton Amazônico, constitui uma massa continental de extensão considerável que tem que ser levada em conta e considerada peça importante nas reconstruções paleogeográficas e nas análises dos cinturōes orogênicos colisionais do MesoNeoproterozóico.

Nesse sentido, a Província Grenville de Norte América é o cinturāo orogênico mais representativo das fases colisionais que terminaram na aglutinação do Supercontinente de Rodínia (HOFFMAN, 1991). Os diferentes eventos tectono-metamórficos presentes no Cinturão Grenville estão agrupados temporalmente em três: o mais antigo entre 1190-1140 Ma (Elzevirian), o intermediário e mais amplamente desenvolvido entre 1080-1020 Ma (Ottawan), e o último entre 1000-980 Ma (Rigolet) (RIVERS, 1997; HANMER et al., 2000 MCMELLAND et al., 1996, 2001). O caráter temporal do metamorfismo do Maciço de Garzón pode ser claramente correlacionado com os eventos orogênicos Rigolet e Ottawan, sugerindo que o maciço participou da formação de Rodínia como elemento dos orógenos colisionais que permitiram a aglutinação desse Supercontinente. As condições do metamorfismo de alto grau do Maciço de Garzón, que indicam profundidades entre 20-30 Km, mostram que este fragmento fazia parte do núcleo colisional. 
Em conclusão, todos estos fragmentos correlacionáveis com o cinturão Grenville, hoje fazendo parte do México, da Colômbia, e de outras regióes da América do Sul, podem ser considerados peças importantes do Supercontinente Rodinia, que foram fragmentadas e separadas emtre si quando aconteceu a separação entre Laurentia e Gondwana no Proterozóico tardío, por volta de $580 \mathrm{Ma}$, durante a formação do Oceano lapetus. 


\section{REFERÊNCIAS BIBLIOGRÁFICAS}

ALVAREZ, W., (1967) Geology of the Simarua and Carpintero area, Guajira Península, Colombia. Ph D. Thesis. Princenton University. $147 \mathrm{p}$.

ALVAREZ, J. A.; LINARES, E. (1985) Una edad K-Ar del Macizo de Garzón, Departamento del Huila, Colombia. Geologia Norandina, v. 9, p. 31-33.

ALVAREZ, J. A. (1981a) Determinación de la edad Rb/Sr en Rocas del Macizo de Garzón Cordillera Oriental de Colombia. Geologia Norandina, v. 4, p. 31-38.

ALVAREZ, J. A. (1981b) Granulitos Charnoquiticos y rocas relacionadas del Macizo de Garzón, Cordillera Oriental (Colombia). In: CONGRESO COLOMBIANO DE GEOLOGIA, 3, Medellín, 1981. Resumenes, $41 \mathrm{p}$.

ALVAREZ, J. A.; CORDANI, U. G. (1980) Precambrian basement within the septentrional Andes: age and geological evolution. In: INT. GEOL. CONGR., 26, Paris, 1980. Abstracts, v. 1, n. 10, p. 18-19.

ANNICCHIARICO, G. P. (2000) Petrografía de treinta muestras pertenecientes al Macizo de Garzón, planchas 389,390 y 414 y cinco muestras correspondientes a la plancha 388 . Bogotá. Ingeominas, informe interno.

ARNDT, N. T.; GOLDSTEIN, S. L. (1987) Use and abuse of crust formation ages. Geology, v. 15, p. $893-895$.

ASPDEN, J. A; McCOURT, W.; BROOK, M. (1987) Geometrical control of the subductionrelated magmatism: the Mesozoic and Cenozoic plutonic history of western Colombia. Journal of the Geological Society, v. 144, p. 893-905.

BEA, F. (1996) Residence of REE, Y, Th and U in Granites and Crustal Protoliths; Implications for the Chemistry of Crustal Melts. Journal of Petrology, v. 37, n. 3, p. 521-552.

BERMAN, R. G. (1991). Thermobarometry using multi-equilibrium calculations: a new technique, with petrological applications. The Canadian Mineralogist, v. 29, p. 833-855.

BERMAN, R. G. (1990) Mixing properties of Ca-Mg-Fe-Mn garnets. The American Mineralogist, v. 75, p. $328-344$.

BERMAN, R. G. (1988) Internally consistent thermodynamic data for minerals in the system $\mathrm{Na}_{2} \mathrm{O}-\mathrm{K}_{2} \mathrm{O}-\mathrm{CaO}-\mathrm{MgO}-\mathrm{FeO}-\mathrm{Fe}_{2} \mathrm{O}_{3}-\mathrm{Al}_{2} \mathrm{O}_{3}-\mathrm{SiO}_{2}-\mathrm{TiO}_{2}-\mathrm{H}_{2} \mathrm{O}-\mathrm{CO}_{2}$. Journal of Petrology, v. 29, p. 445-522.

BHATTACHARYA, A.; KRISHNAKUMAR, K. R.; RAITH, M.; SEN, S. K. (1991) An improved Set of a-X Parameters for Fe-Mg-Ca Garnets and Refinements of the Orthopyroxene-Garnet Thermometer and the Orthopyroxene-Garnet-Plagioclase-Quartz Barometer. Journal of Petrology, v. 32, n. 3, p. 629-656. 
BOHLEN, S. R.; ESSENE, E. J. (1980) Evaluating of coexisting garnet-biotite, garnetclinopyroxene and other $\mathrm{Mg}-\mathrm{Fe}$ exchange thermometers in Adirondack granulites, summary. Geol. Soc. of America Bull., v. I, p. 105-107.

BRIDGER, C. S. (1982) El Paleozoico inferior de Colombia. Bogotá. Tesis de grado. Univ. Nacional de Colombia.

BROWN, M. (1993) P-T-t evolution of orogenic belts and the causes of regional metamorphism. Journal of the Geol. Society London, v. 150, p. 227-241.

BUCHER, K.; FREY, M. (1994) Petrogenesis of Metamorphic Rocks. $6^{\text {th }}$ ed., Berlin, SpringerVerlag. $318 \mathrm{p}$.

CARDONA, A. (2003) Correlações entre fragmentos do embasamento Pré-Mesozóico da terminação setentrional dos Andes colombianos, com base em dados isotópicos $e$ geocronológicos. Dissertação de Mestrado, Instituto de Geociências - Universidade de São Paulo. 143 p.

COLLERSON, K. D. (1976) Composition and structural state of alkali feldspars from highgrade metamorphic rocks, central Australia. American Mineralogist, v. 61, p. 200-211.

CONDIE, K. C. (1997) Plate tectonics and crustal evolution, 4 ed., Oxford, ButterwworthHeinemann, $2282 \mathrm{p}$.

CORDANI, U. G.; SATO, K.; TEIXEIRA, W.; TASSINARI, C. C. G.; BASEI, M. A. S. (2000) Crustal Evolution of the South American Platform In: CORDANI, U. G.; MILANI, E.; THOMAZ FILHO, A.; CAMPOS, D. (eds), Tectonic Evolution of South América, $31^{\text {st }}$ International Geological Congress, Rio de Janeiro-Brazil, 856 p.

CORDANI, U. G.; SATO, K. (1999) Crustal evolution of the South American Platform, based on $\mathrm{Nd}$ isotopic systematics on granitoid rocks. Episodes, v. 22, n. 3, p. 167-173.

DASGUPTA, S.; SENGUPTA, P.; GUHA, D.; FUKUOKA, M. (1991) A refined garnet - biotite $\mathrm{Fe}-\mathrm{Mg}$ exchange geothermometer and its application in amphibolites and granulites. Contrib. Mineral. Petrol, v. 109, p. 130-137.

DENGO, C. A.; COVEY, M. C. (1993) Structure of the Eastern Cordillera of Colômbia: Implications for Trap Styles and Regional Tectonics. The American Ass. Of Petroleum Geologists Bulletin, v. 77, n. 8, p. 1315-1337.

De PAOLO, D. J. (1981) Neodymium isotopes in the Colorado Front Range and crust-mantle evolution in the Proterozoic. Nature, v. 291, p. 193-196.

De PAOLO, D. J.; LINN, A. M.; SCHUBERT, G. (1991) The Continental Crustal Age Distribution: Methods of Determining Mantle Separation Ages From Sm-Nd Isotopic Data and Application to the Southwestern United States. J. of Geophysical Research, v. 96, n. B2, p. 2071-2088. 
De PAOLO, D. J. (1988) Neodymium isotope geochemistry: An introduction. New York, Springer Verlag, $p$.

DICKIN, A. P. (1995) Radiogenic Isotope Geology. Cambridge University. Press. 490 p.

DODSON, M. H. (1973) Closure temperature in cooling geochronological and petrological systems. Contrib. Mineral. Petrol., v. 40, p. 259-274.

ENGLAND, P. C.; THOMPSON, A. B.; (1984) Pressure-temperature-time paths of regional metamorphism I. Heat transfer during the evolution of regions of thickened continental crust. Journal of Petrology, 25, p. 894-928.

FAURE, G. (1986) Principles of Isotope Geology. $2^{\text {nd }}$ ed., John Wiley \& Sons. 589p.

FAURE, G.; POWELL, J. L. (1972) Strontium Isotope Geology. Springer-Verlag, BerlinHeidelberg-New York. (Monograph Series of Theoretical and Experimental Studies, 5).

FERRY, J. M.; SPEAR, F. S. (1978) Experimental Calibration of the Partitioning of $\mathrm{Fe}$ and $\mathrm{Mg}$ Between Biotite and Garnet. Contrib. Mineral. Petrol., v. 66, p. 113-117.

FREYMUELLER, J.; KELLOGG, J; VEGA, V. (1993) Plate motions in the North Andean region. Journal of Geophysical Research, v. 98, p. 21853-21863.

FUHRMAN, M. L. \& LINDSLEY, D. H. (1988) Ternary-feldspar modeling and thermometry. The American Mineralogist, v. 73, p. 201-216.

GALVIS, J. (1979) Geología de la Amazonía Colombiana. Boletín Geológico Ingeominas, v. 22, n. 3, p. 3-86.

GANGULY, J.; SAXENA, S. K. (1984) Mixing properties of aluminosilicate garnets: constraints from natural and experimental data, and applications to geothermo-barometry. American Mineralogist, v. 69, p. 88-97.

GOLDMAN, D. S.; ALBEE, A. L. (1977) Correlation of Mg/Fe partitioning between garnet and biotite with ${ }^{18} \mathrm{O} /{ }^{16} \mathrm{O}$ partitioning between quartz and magnetite. Ame. J. of Science, v. 277, p. 750-767.

GOMEZ, M. (2002) Petrografía de veinte muestras pertenecientes al Macizo de Garzón, planchas 389 y 414 . Bogotá. Ingeominas, informe interno.

GROSSE, E. (1935) Acerca de la geología del sur de Colombia. Informe rendido al Ministerio de Industria sobre un viaje al Huila y alto Caquetá. Comp. Est. Geol. Of. Col. V. 3, p. 31-137.

GUIDOTTI, C. V. (1984) Micas in Metamorphic Rocks. In: BAlLEY, S.W. (ed.). Micas: Mineralogical Society of America Reviews of Mineralogy, v. 13, p. 357-467. 
HANMER, S., CORRIGAN, D., PEHRSSON, S., NADEAU, L. (2000). SW Grenville Province Canada: the case against post-1.4 Ga accretionary tectonics. Tectonophysics, v. 319, p. 33-51.

HODGES, K. V. (1991) Pressure-temperature-time Paths. Annu. Rev. Earth Planet. Sci., v. 19, p. 207-236.

HODGES, K. V.; SPEAR, F. S. (1982) Geothermometry, geobarometry and the $\mathrm{Al}_{2} \mathrm{SiO}_{5}$ triple point at Mt. Moosilauke, New Hampshire. American Mineralogist, v. 67, p. 1118-1134.

HOFFMAN, P. A . (1991) Did the birth of North America turn Gondwana inside out? Science, V. 252. P. 1409-1411.

HOLDAWAY, M. J.; (1971) Stability of andalusite and the aluminum silicate phase diagram. Am. Journal Sci., v. 271, p. 97-131.

HOLDAWAY, M. J.; LEE, S. M. (1977) Fe-Mg cordierite in high grade politic rocks based on experimental and natural observations. Contrib. to Mineralogy and Petrology, v. 63, p. 175198.

HOSKIN, P. W. O.; BLACK, L. P. (2000) Metamorphic zircon formation by solid-state recrystallization of protolith igneous zircon. J. metamorphic Geol., v. 18, p. 423-439.

INDARES, A.; MARTIGNOLE, J. (1985) Biotite-garnet geothermometry in the granulite facies: the influence of $\mathrm{Ti}$ and $\mathrm{Al}$ in biotite. American Mineralogist, v. 70, p. 272-278.

INGEOMINAS; GEOESTUDIOS LTDA, (2001a) Geologia de las planchas 367, 368, 389, 390 y 414. Licitación 004 de 1999. Bogotá (Escala 1:100.000).

INGEOMINAS; GEOESTUDIOS LTDA, (2001b) Geologia de la plancha 411, 412, 430, 431, 448,449 y 465 . Contrato 261 de 1999. Bogotá (Escala 1:100.000).

KAY, S.M.; ORREL, S.; ABBRUZZI, J. M (1996) Zircon and whole rock Nd-Pb isotopic evidence for a Grenville age and Laurentian origin for the basement of the Precordilleran in Argentina. J. of Geology, v. 104, p. 637-648.

KEPPIE, J. D.; DOSTAL, J.; CAMERON, K. L.; SOLARI, L. A .; ORTEGA-GUTIERREZ, F.; LOPEZ, R. (2003) Geochronology and geochemistry of Grenvillian igneous suites in the northern Oaxacan Complex, southern Mexico: tectonic implications. Precambrian Research, v. 120 , p. $365-389$.

KEPPIE, J.; DOSTAL, F.; ORTEGA-GUTIERREZ, F.; LOPEZ, R. (2001) A Grenvillian arc on the margin of Amazonia: evidence from the southern Oaxacan Complex, southern Mexico. Precambrian Research, v. 112, p. 165-181.

KEPPIE, J.; ORTEGA-GUTIERREZ, F. (1999) Middle American Precambrian basement: a missing piece of the reconstructed 1 Ga orogen. In: RAMOS, V. A.; KEPPIE, J. D.; (ed.), Laurentiaa-Gondwana Connections before Pangea. Special Paper Geol. Soc. Of America 336, p. $199-210$. 
KRETZ, R. (1983) Symbols for rock-forming minerals. American Mineralogist, v. 68, p. 277279.

KRIEGSMAN, L. M. (2001) Partial meeting, partial melt extraction and partial back reaction in anatectic migmatites. Lithos, v. 56, p. 75-96.

KRIEGSMAN, L. M.; HENSEN, B. J. (1998) Back reaction between restite and melt: Implications for geothermobarometry and pressure-temperature paths. Geology, v. 26, n. 12, p. $1111-1114$.

KROONENBERG, S. B. (2001) La Colisión Continental entre Amazonia y Laurentia $1100 \mathrm{Ma}$ atrás. In: COLOQUIO SOBRE O PRECÁMBRICO DE COLOMBIA, Bogotá, 2001. Resumenes. Bogotá, Ingeominas.

KROONENBERG, S. B. (1982) Litología, metamorfismo y origin de las granulitas del Macizo de Garzón, Cordillera Oriental (Colombia). Geologia Norandina, Bogotá, v. 6, p. 39-46.

LAL, R. K. (1993) Internally consistent recalibrations of mineral equilibria for geothermobarometry involving garnet-orthopyroxene-plagioclase-quartz assemblages and their application to the South Indian granulites. J. metamorphic Geol., v. 11, p. 855-866.

LAVRENT'EVA, I. V.; PERCHUK, L. L. (1990) Orthopyroxene-garnet geothermometer: Experimental data. Doklady Akademii Nauk SSSR, v. 310, p. 1779-1782.

LAVRENT'EVA, I. V.; PERCHUK, L. L. (1981) Cordierite-garnet thermometer. Doklady Akademii Nauk SSSR, v. 259, p. 697-700.

LEAKE, B. E.; WOOLLEY, A. R.; ARPS, C. E. S.; BIRCH, W. D.; GILBERT, M. C.; GRICE, J. D.; HAWTHORNE, F. C.; KATO, A.; KISCH, H. J.; KRIVOVICHEV, V. G.; LINTHOUT, K.; LAIRD, J.; MANDARINO, J.; MARESCH, W. V.; NICKEL., E. H.; SCHUMACHER, J. C.; SMITH, D. C.; STEPHENSON, N. C. N.; UNGARETTI, L.; WHITTAKER, E. J. W.; YOUZHI, G. (1997) Nomenclatures of Amphiboles: Report of the Subcommittee on Amphiboles of the International Mineralogical Association Commission on New Minerals and Mineral Names. Mineralogical Magazine, v. 61, p. 295-321.

LE BRETON, N.; THOMPSON, A. B. (1988) Fluid-absent (dehydration) melting of biotite in metapelites in the early stages of crustal anatexis. Contrib. to Mineralogy and Petrology, v. 99, p. 226-237.

LUDWIG, K. R. (2001) Squid 1.02 A User's Manual. Special Publication n. 2. Berkeley Geochronology Center.

LUDWIG, K. R. (1999) Isoplot/Ex version 2.10. A Geochronological Toolkit for Microsoft Excel. Special Publication n. 1a. Berkeley Geochronology Center.

MCDOUGALL, I.; HARRISON, T. M. (1999) Geochronology and Thermochronology by the ${ }^{40}$ Ar ${ }^{\beta 9}$ Ar method. Second Edition. New York, Oxford University Press. 269 p. 
MCLELLAND, J.; HAMILTON, M.; SELLECK, B.; MCMELLAND, J. M.; WALKER, D.; ORELL, S. (2001) Zircon U-Pb Geochronology of the Ottawan Orogeny, Adirondack Highlands, New York: Regional and tectonic implications. Precambrian Research, v. 109, p. 39-72.

McLELLAND, J.; DALY, SS.; McLELLAND, J. M. (1996) The Grenville Orogenic Cycle (ca. 1350-1000Ma): an Adirondack perspective. Tectonophysics, v. 265, p. 1-28.

MCMULLIN, D.; BERMAN, R. G.; GREENWOOD, H. J. (1991) Calibration of the SGAM thermobarometer for pelitic rocks using data from phase equilibrium experiments and natural assemblages. Can. Mineral., v. 29, p. 889-908.

MEZGER, E. J.; ESSENE, E. J.; HALLIDAY, A. N. (1992) Closure temperatures of the Sm-Nd system in metamorphic garnets. Earth and Planetary Science Letters, v. 113, p. 397-409.

MICHARD, A.; GURRIET, P.; SOUNDANT, M.; ALBAREDE, F. (1985) Nd isotopes in French Phanerozoic shales: external vs. internal aspects of crustal evolution. Geochimica et Cosmochimica Acta, v. 49, p. 601-610.

MUNHÁ, J. M.; TASSINARI, C. C. G. (1999) Modelos de difusão em termocronologia metamórfica: filosofia e métodos. Revista Brasileira de Geociências, v. 29, n. 4, p. 593-598.

NEWTON, R. C. (1983) Geobarometry of high-grade metamorphic rocks. American Journal of Science, v. 283-A, p. 1-28.

NEWTON, R. C.; PERKINS, D. (1982) Thermodynamic calibration of geobarometers based on the assemblages garnet-plagioclase-orthopyroxene (clinopyroxene)-quartz. American Mineralogist, v. 67, p. 203-222.

NUTMAN, A. (2000) Lectures on Zirconology, Notes, November. Instituto de Geociências Universidade de São Paulo, unpublished manuscript.

ORDOŇEZ, O. (1997) O pré-Cambriano na parte norte da Cordilheira Central dos Andes colombianos. Brasilia. Tese (Mestrado) - Instituto de Geociências, Universidade de Brasília.

ORDOŇEZ, O. (2001) Caracterização isotópica $\mathrm{Rb}-\mathrm{Sr}$ e $\mathrm{Sm}-\mathrm{Nd}$ dos principais eventos magmáticos nos Andes Colombianos. Tese de Doutoramento. Instituto de Geociências, Universidade de Brasília, 197 p.

PERCHUK, L. L.; ARANOVICH, L. Ya.; PODLESSKII, K. K.; LAVRANT'EVA, I. V.; GERASIMOV, V. YU.; FED'KIN, V. V.; KITSUL, V. I.; KARSAKOV, L. P.; BERDNIKOV, N. V. (1985) Precambrian granulites of the Aldan shield, eastern Sibéria, USSR. J. metamorphic Geol., v. 3, p. 265-310.

PERCHUK, L. L.; LAVRENT'EVA, I. V. (1983) Experimental investigation of exchange equilibria in the system cordierite-garnet-biotite. In: SAXENA, S. K. (ed.) Kinetics and Equilibrium in Mineral Reactions, Advances in Physical Chemistry, New York, Springer-Verlag, v. 3, p. 199-239. 
PIGAGE, L. C.; GREENWOOD, H. J. (1982) Internally consistent estimates of pressure and temperature: the staurolite problem. Am. J. of Science, v. 282, p. 943-969.

PRIEM, H. N. A.; KROONEMBERG, S. B.; BOELRIJK, N. A. I. M.; HEBEDA, E. H. (1989) RbSr and K-Ar evidence of $1.6 \mathrm{Ga}$ basement underlying the $1.2 \mathrm{Ga}$ Garzon-Santa Marta granulitic belt in the Colombian Andes. Precambrian Research, v. 42, p. 315-324.

RADELLL, L. (1962) Introducción al estudio de la petrografía del Macizo de Garzón, Huila (Colombia). Geologia Colombiana Univ. Nacional de Colombia, v. 3, p. 17-46.

RAMOS, V. A. (1988) Late Proterozoic-Early Paleozoic of South America- a Collisional History. Episodes, v. 11, n. 3. p. 168-174.

RECHE, J.; MARTINEZ, F. J. (1996) GPT An excel spreadsheet for thermobarometric calculation in metapelitic rock. Computer and Geosciences, v. 22, n. 7, p. 775-784.

RESTREPO, J. J.; TOUSSAINT, J. F. (1988) Terranes and continental accretion in the Colombian Andes. Episodes 11, p. 189-193.

RESTREPO-PACE, P. A.; GEHRELS, G.; COSCA, M. (1997) Geochronology and Nd isotopic data of Grenville-age rocks in the Colombian Andes: new constraints for Late Proterozoic-Early Paleozoic paleocontinental reconstructions of the Americas. Earth and Planetary Science Letters, v. 150, p. 427-441.

RESTREPO-PACE, P. A. (1995) Late Precambrian to Early Mesozoic Tectonic Evolution of the Colombian Andes, based on new Geochronological, Geochemical and Isotopic data. Thesis Ph D. University of Arizona.

RIDLEY, J. (1989) Vertical movement in orogenic belts and the timing of metamorphism relative to deformation. In: DALY, R.; CLIFF, R. A.; YARDLEY, W. D. Evolution of Metamorphic Belts - Geological Society Special Publication Classics. London, Geological Society, p. 103115.

RIEDER, M.; CAVAZZINI, G.; D'YAKONOV, Y.; FRANK-KAMENETSKII, V. A.; GOTTARDI, G.; GUGGENHEIM, S.; KOVAL, P. V.; MÜLLER, G.; NEIVA, A. M. R.; RADOSLOVICH, E. W.; ROBERT, J-L.; SASSI, F. O.; TAKEDA, H.; WEISS, Z.; WONES, D. R. (1998) Nomenclature of the Micas. The Canadian Mineralogist, v. 36, p. 42-48.

RIVERS, T. (1997) Lithotectonic elements of the Grenville Province: review and tectonic implications. Precambrian Research, v. 86, p. 117-154.

ROBINSON, P. (1991) The eye of the petrographer, the mind of the petrologist. American Mineralogist, v. 76, p. 1781-1810.

RODRIGUEZ, G.; ZAPATA, G.; VELASQUEZ, M. E.; COSSIO, U.; LONDOÑO, A. C. (2002) Geología de las planchas $367,368,389,391$ y 414 . Departamentos del Caqueta y del Huila Medellín. Ingeominas, informe interno.

RODRIGUEZ, G. (1985) Petrografía y Microtexturas del Grupo Garzón y el Granito de anatexis de El Recreo, Macizo de Garzón, Cordillera Oriental, Colombia. Revista Ingeominas, N. 5, p. 
RUIZ, J.; TOSDAL, R. M.; RESTREPO-PACE, P. A.; MURILLO-MUŇETON, G. (1999) Pb isotope evidence for Colombia-southern México connections in the Proterozoic. Geol. Soc. Of America Special Paper 336, p. 183-197.

SATO, K.; TASSINARI, C. C. G.; KAWASHITA, K.; PETRONILHO, L. (1995) O Método Geocronológico Sm-Nd no IG/USP e suas Aplicações. An. Acad. Bras. Ci., v. 67, n. 3, p. 313336.

SATO, K. (1998) Evolução crustal da Plataforma Sul Americana, com base na geoquímica isotópica Sm-Nd. Tese de Doutorado. Instituto de Geociências Universidade de São Paulo. p.

SEN, S. K.; BHATTACHARYA, A. (1984) An orthopyroxene-garnet thermometer and its application to the Madra charnockites. Contrib. Mineral. Petrol, v. 88, p. 64-71.

SAWYER, E. W. (1999) Criteria for the Recognition of Partial Melting. Phys. Chem. Earth (A), v. 24, n. 3 , p. 269-279.

SOLARI, L. A.; KEPPIE, J. D.; ORTEGA-GUTIERREZ, F.; CAMERON, K. L.; LOPEZZ, R.; HAMESS, W. E. (2003) 990 and 1100 Ma Grenvillian tectonothermal events in the northern Oaxacan Complex, southern Mexico: roots of an orogen. Tectonophysics 6847, p. 1-26.

SPEAR, F. S. (1991) On the interpretation of peak metamorphic temperatures in the light of garnet diffusion during cooling. J. Metamorphic Geol., v. 9, p. 379-388.

SPEAR, F. S.; HICKMOTT, D. D.; SELVERSTONE, J. (1990) Metamorphic consequences of thrust emplacement, Fall Mountain, New Hampshire. Geol. Soc. Of America Bull., v. 102, p. 1344-1360.

SPEAR, F. S. (1985) Metamorphic Phase Equilibria and Pressure-Temperature-Time Paths. Washington, D.C. Mineralogical Society of America, 799 p.

SPEAR, F. S.; SELVERSTONE, J. (1983) Quantitative P-T Paths from Zoned Minerals: Theory and Tectonic Applications. Contrib. Mineral. Petrol., v. 83, p. 348-357.

STEIGER, R. H.; JÄGER, E. (1977) Subcommission on geochronology: Convention on the use of decay constants in geo- and cosmochronology. Earth. Planet. Sci. Lett., V. 36, p. 359-362.

TABOADA, A.; RIVERA, L. A.; FUENZALIDA, A.; CISTERNAS, A.; PHILIP, H.; BIJWAARD, H.; OLAYA, J.; RIVERA, C. (2000) Geodynamics of the northern Andes: Subductions and intracontinental deformation (Colombia). Tectonics, v. 19, n. 5, p. 787-813.

TASSINARI, C. C. G. (1996) O Mapa geocronológico do Cráton Amazônico no Brasil: Revisão dos dados isotópicos. Tese de Livre-Docente, Departamento de Geologia Geral. Instituto de Geociências, Universidade de São Paulo.

TERA, F.; WASSERBURG, G. F. (1974) U-Th-Pb systematics in three Apollo 14 basalts and the problem with initial $\mathrm{Pb}$ in Lunar rocks. Earth Planet. Sci. Lett., v. 14, p. 281-304. 
THOMPSON, A. B. (2001) P-T Paths, $\mathrm{H}_{2} \mathrm{O}$ Recycling, and Depth of Crystallisation for Crystal Melts. Phys. Chem. Herat (A), v. 26, n. 4-5, p. 231-237.

THOMPSON, A. B.; ENGLAND, P. C. (1984) Pressure-temperature-time paths of regional metamorphism II. Their inference and interpretation using mineral assemblages in metamorphic rocks. Journal of Petrology, 25, p. 929-955.

THOMPSON, J. B. (1976) Mineral reactions in pelitic rocks II. Calculation of some P-T-X (Fe$\mathrm{Mg}$ ) phase relations. Ame. J. of Science, v. 276, p. 425-454.

TOUSSAINT, J. F. (1993) Evolución geológica de Colombia. Precámbrico-Paleozóico. Universidad Nacional de Colombia, Medellín. 129p.

TOSDAL, R. M.; BETTENCOURT, J. S. (1994) UmPb zircon and Pb isotopic compositions of Middle Proterozoic Rondonian Massifs, southwestern margin of the Amazonan Craton, Brazil $7^{\circledR}$ Congreso Geologico Chileno, Actas V, II, p. 1538-1541.

TOSDAL, R. M. (1996) The Amazon-Laurentian connection as viewed from the Middle Proterozoic rocks in the Central Andes, Western Bolivia and northern Chile. Tectonics, v. 15, n. 4, p. 827-842.

TSCHANZ, C. M.; MARVIN, R. F.; CRUZ, J. (1974) Geologic evolution of the Sierra Nevada de Santa Marta area, Colombia. Geol. Soc. Of America Bull., v. 85, p. 273-284.

VABRA, G.; SCHMID, R.; GEBAUER, D. (1999) Internal morphology, habit and U-Th-Pb microanalysis of amphibolite-to-granulite facies zircons: geochronology of the Ivrea Zone (Southern Alps). Contrib. Mineral. Petrol., v. 134, p. 380-404.

VAN DER PLUIJM, B. A.; MEZGER, K.; COSCA, M. A.; ESSENE, E. J. (1994) Determining the significance of high-grade shear zones by using temperature-time paths, with examples from the Grenville orogen. Geology, v. 22, p. $743-746$.

VAN DER WIEL, A. M. (1991) Uplift and volcanism of the SE Colombian Andes in relation to Neogene sedimentation in the Upper Magdalena Valley. Thesis PhD U. Agriculture University of Wageningen. Amsterdam. The Netherlands.

VASCONCELOS, P. M.; ONOE, A. T.; KAWASHITA, K.; SOARES, A. J.; TEIXEIRA, W. (2002) ${ }^{40} \mathrm{Ar} /{ }^{39} \mathrm{Ar}$ geochronology at the Instituto de Geociências, USP: instrumentation, analytical procedures, and calibration. Anais da Academia Brasileira de Ciências, v. 74, n. 2, p. 297-342.

VELANDIA, F.; TERRAZA, R.; VILLEGAS, H. (2001) El Sistema de fallas de Algeciras hacia el suroeste de Colombia y la actual transpresión de los Andes del norte. In: CONGRESO COLOMBIANO DE GEOLOGIA, Manizales, 2001. CD con resumenes.

VESGA, C. J.; BARRERO, D. (1978) Edades KAr en rocas ígneas y metamórficas de la Cordillera Central de Colombia y su implicación geológica. In: Il Congreso Colombiano de Geología, Bogotá, Resumenes.

VILLA, I. M. (1998) Isotopic closure. Terra Nova, v. 10, p. $42-47$. 
VINASCO, C. J.; CORDANI, U. G.; VASCONCELOS, P. (2001) ${ }^{40} A r /{ }^{39} A r$ dates in Central Cordillera of Colombia Evidence for a Upper Triassic Regional Tectonomagmatic Event. III South American Symposium on Isotope Geology, Chile. CD con resumenes.

WASTENEYS, H. A.; CLARK, A. H.; FARRAR, E.; LANGRIDGE, R. J. (1995) Grenvillian granulite-facies metamorphism in the Arequipa Massif, Peru: a Laurentia-Gondwana link. Earth Planet. Sci. Lett., v. 132, p. 63-73

WATERS, D. J. (2001) The significance of prograde and retrograde quartz-bearing intergrowth microstructures in partially melted granulite-facies rocks. Lithos, v. 56, p. 97-110.

WATSON, B. E; HARRISON, M. T. (1983) Zircon saturation revisited: temperature and composition effects in a variety of crustal magma types. Earth Planet. Sci. Lett., v. 64, p. 295304.

WETHERHILL, G. W. (1956) Discordant uranium-lead ages. Transaction American Geophysical Union, 37, p. 320-326.

WILLIAMS, M. L.; GRAMBLING, J. A. (1990) Manganese, ferric iron, and the equilibrium between garnet and biotite. American Mineralogist, v. 75, p. 886-908.

WINDLEY, B. F. (1995) The evolving continents, 3 ed., Chichester, John Wiley \& Sons. 526 p 


\section{ANEXO II - Características gerais dos minerais das rochas regionais do Maciço de Garzón}

\section{GUAPOTÓN-MANCAGUA, GNAISSES:}

Quartzo: monocristalino anedral de granulação média a grossa, e com extinção ondulante. Ocasionalmente apresenta textura mirmequítica, simplectítica (entre Bt-Qtz e Px-Qtz) e aparece freqüentemente como inclusões finas anedrais em outros cristais de Qtz, PI e Kfs. O conteúdo varia de $8 \%$ a $34 \%$.

Plagioclásio $\left(A n_{20-35}\right)$ : cristais anedrais de granulação media a grossa, geminados segundo a Lei da Albita e Periclinio, parcialmente sericitizados. Alguns apresentam texturas antipertíticas tipo bead (com menos de $1 \%$ de microclínio) e estão substituídos por Kfs. Também encontra-se como inclusões finas, inseridas em quartzo e $k$-feldspato. O conteúdo varia de $13 \%$ a $42 \%$.

Encontra-se Mc e também, possivelmente, Or pertítico. Pela incerteza, denomina-se o último genericamente de $\mathrm{Kfs}$. O conteúdo global varia de 24 a $44 \%$.

Microclínio: cristais anedrais de granulação média a grossa com a geminação típica em grade. São comuns as pertitas tipo bead (com 1 a $30 \%$ da fase sódica); e localmente observou-se Mc com pertitas em duas direções diferentes.

k-feldspato: Cristais anedrais de granulação média a grossa, sem geminação caracteristica de Mc, pertiticos a mesopertíticos tipo stringlets e string (com um 30 a $50 \%$ da fase sódica). Localmente os cristais estão caulinizados.

Hornblenda: cristais tabulares anedrais a subeuhedrais de granulação fina a grossa, de cor verde escura (principalmente) ou marrom escura, com forte pleocroismo. Ocasionalmente apresenta textura simplectitica entre Qtz e $\mathrm{Hbl}$. A percentagem varia de 5 a $14 \%$.

Biotita: Cristais tabulares subeuhedrais de granulaçăo fina a grossa, de cor e pleocroismo marrom escuro; às vezes apresentam textura simplectítica e poikilitica com inclusões de Qtz, Ap e Zrn. O conteúdo varia de 2 a $3 \%$.

Outros: O mineral opaco é Mag em quantidades desde traço até $5 \%$. Os principais minerais acessórios são Zrn, Ap e Aln. Pela alteração hidrotermal gerou-se Ms, sericita e Ep.

\section{VERGEL, GRANULITOS:}

Quartzo: monocristalino, anedral, de granulaçăo fina a grossa. Algumas amostras expõem Qtz policristalino com extinção ondulante. Ocasionalmente tem textura mirmequítica (Qtz vermiforme em $\mathrm{Pl}$, em contato com $\mathrm{Kfs}$ ). Também apresentam-se em cristais finos, goticulares, inseridos em outros quartzos, plagioclásio, feldspato. O conteúdo varia de 2 a $60 \%$.

Plagioclásio $\left(\mathbf{A n}_{23-41}\right)$ : Cristais anedrais de granulação fina a grossa, geminados segundo a Lei da Albita, Periclínio e Carlsbad, ocasionalmente sericitizados. Alguns exibem texturas antipertíticas tipo bead (com $<1 \%$ de Or). O conteúdo varia de 8 a $53 \%$.

Feldspato potássico: Cristais anedrais de granulação fina a grossa e alguns com ligeira caulinização; com texturas pertiticas (com um 20 a $45 \%$ de $\mathrm{Pl}$ ) e ocasionalmente mesopertítica, tipo stringlets e strings (gotas e gotinhas). O conteúdo varia de 0 a $65 \%$. 
Ortopiroxênio (Hiperstênio): Cristais anedrais de granulação fina a grossa e forte pleocroismo rosado. Alguns com textura sagenitica (oxidaçăo através da clivagem). Extinção quase paralela $\left(0-5^{\circ}\right)$ e $2 \mathrm{~V}$ alto $\left(75-90^{\circ}\right)$. Altera para $\mathrm{Chl}$, $\mathrm{Tr}$, e minerais de Srp; deixando um remanescente de carbonato. conteúdo varia de 1 a $30 \%$.

Clinopiroxênio: Cristais anedrais de granulação fina a grossa e leve pleocroismo verde. Extinção de $8^{\circ}$ (augita-egirina) $040^{\circ}$ (augita) e $2 \mathrm{~V}$ meios a altos $\left(50-80^{\circ}\right.$ ), com uma percentagem do 3 a $28 \%$. Altera a Chl, Tr e minerais de Srp.

Hornblenda: Cristais tabulares anedrais a subeuhedrais de granulação fina a média, de cor verde escura a marrom escura, forte pleocroismo e uma percentagem que varia de 0 a $58 \%$.

Biotita: Cristais tabulares subeuhedrais de granulação fina a média, cor vermelha a marrom escuro, forte pleocroismo vermelho escuro. Encontra-se associada à Mag. Ocasionalmente apresenta textura simplectítica com Qtz, ou vermiforme. O conteúdo varia de 1 a $21 \%$

Granada (almandina): Cristais anedrais poikilíticos de granulaçăo fina a média, incolores a rosados. Contêm inclusões de Bt e Qtz; com uma percentagem que varia de 0 a $5 \%$.

Os principais minerais opacos são Mag e Ttn com valores de 0 a $15 \%$, e Py disseminada associada ao hidrotermalismo junto com sericita, Ep e Gn. Os acessórios observados foram Zrn, Ap, Mnz.

\section{VERGEL, ROCHAS GNÁISSICAS:}

A diferença das rochas anteriores estas contêm Mc e não apresentam Opx. Em geral os gnaisses constituem -se dos mesmos minerais dos granulitos, e apresentam feições similares com exceção de:

Quartzo: Não têm texturas mirmequiticas. São comuns cristais finos inseridos em Kfs, Pl, Grt. O conteúdo varia de 20 a $60 \%$.

Ortoclásio: Cristais pertiticos com formas orientadas; localmente com inclusões de Qtz e Bt. O conteúdo varia de 3 a $51 \%$.

Microclínio: Cristais limpidos de granulação fina com a caracteristica geminação em grade. $O$ conteúdo varia de 0 a $6 \%$.

Plagioclásio: $O$ conteúdo varia de 3 a $48 \%$.

Clinopiroxênio (augita-egirina, egirina-enstatita): Alguns cristais estao alterados a Chl, minerais de $\mathrm{Srp}$ e carbonatos. Associados à $\mathrm{Hbl}$. O conteúdo varia de 0 a $5 \%$.

Hornblenda: Encontra-se intercrescida com Bt, associada à Mag e formada pela alteração de Px; localmente tem inclusões de Qtz e Bt. O conteúdo varia de 0 a $8 \%$.

Biotita: localmente está cloritizada, com desenvolvimento de Ep e carbonatos. Tem textura simplectitica com Qtz e Mag. Ocasionalmente desenvolve halos pleocróicos em Zm. O conteúdo varia de 1 a $8 \%$.

Granada: Cristais poikiliticos com inclusões de Qtz. A Grt está em paragêneses com Bt e localmente alterada a Chl. O conteúdo varia de 0 a $14 \%$. 


\section{MARGARITAS, PARAGNAISSES:}

Quartzo: Monocristalino, anedral, de granulação média. Alguns cristais tem extinção ondulante. Aparece como cristais finos inseridos em Qtz, Kfs e Pl. Ocasionalmente com textura mirmequítica, micrográfica e simplectítica (entre Qtz e Bt). O conteúdo varia de 23 a $57 \%$.

k-feldspato: Cristais anedrais de granulação média e ligeira caulinização com texturas pertiticas a mesopertíticas (com 30 a $50 \%$ da fase sódica) tipo stringlets, strings e bead (gotas, gotinhas e borbulhas).

Microclínio: Geralmente antipertitico tipo bead (menos de 1\% de Mc inserido em Pl) e stringlets (5\% de gotas de $\mathrm{Mc}$ em Pl). Também, aparece como cristais límpidos, geminados, com inclusões de Qtz. O conteúdo de Kfs e Mc varia de 0 a $17 \%$.

Plagioclásio $\left(\mathrm{An}_{30.50}\right)$ : Cristais anedrais de granulação média, as vezes geminados segundo a Lei da Albita e Periclínio; ocasionalmente sericitizados. Alguns cristais exibem textura antipertitica tipo bead (Mc numa percentagem de 1 a 10\% inserido em PI); outros estão como inclusões em Qtz. O conteúdo varia de 12 a $51 \%$.

Clinopiroxênio (augita-egirina): Cristais geralmente alterados a $\mathrm{Chl}$, sericita e alguns completamente serpentinizados. O conteúdo varia de 0 a $6 \%$.

Biotita: Observam-se duas gerações diferentes, uma delas paralela à foliação, marrom, fortemente alterada a Chl; e outra perpendicular à foliação, de granulaçăo mais fina e sem alteraçăo. A percentagem varia de 1 a $35 \%$.

Granada (almandina-piropo): Porfiroblastos poikiliticos de granulação fina a média e cor rosada. Ocasionalmente com desenvolvimento de $\mathrm{Chl}$ em zonas de fratura e alteração a Ms nas bordas. Alguns com bordas de reação a PI. O conteúdo varia de 0 a $11 \%$.

Sillimanita: Cristais prismáticos euhedrais de granulação fina, incolores, associados às bandas de Bt castanha. As vezes altera-se para minerais de argila (pirofilita?).

Outros: O principal mineral opaco é Mag em pequena quantidade e Py associada a hidrotermalismo. Os acessórios são Zrn, Ap (granulação fina a média) e monazita?; estos atingem percentagem de até $2 \%$. 
ANEXO III - Análises de microsonda eletrônica e composição mineralógica

Lâmina V-332, granulito

\section{Granada}

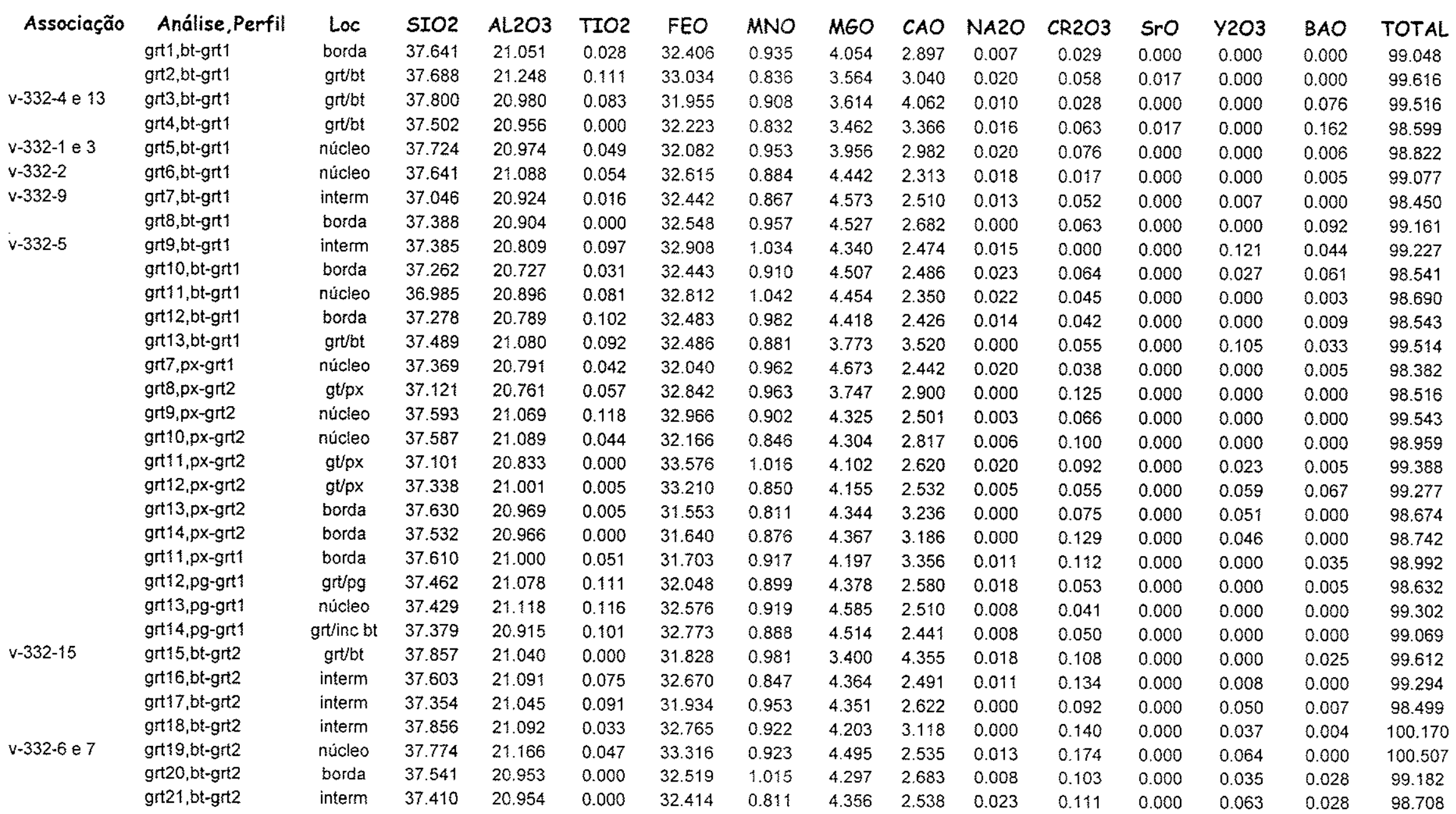




\begin{tabular}{|c|c|c|c|c|c|c|c|c|c|c|c|c|}
\hline \multirow{2}{*}{ Associação } & \multirow[b]{2}{*}{ Análise,Perfil } & & \multicolumn{10}{|c|}{ Cations (24 oxigenios) } \\
\hline & & TSI & TAL & ALVI & FE3 & TI & $C R$ & FE2 & $M G$ & $M N$ & $C A$ & $N A$ \\
\hline & grt1, bt-grt1 & 6.051 & 0.000 & 3.985 & 0.000 & 0.003 & 0.004 & 4.357 & 0.972 & 0.127 & 0.499 & 0.002 \\
\hline & gtt2,bt-grt1 & 6.043 & 0.000 & 4.012 & 0.000 & 0.013 & 0.007 & 4.430 & 0.852 & 0.114 & 0.522 & 0.006 \\
\hline \multirow[t]{2}{*}{$v-332-4$ e 13} & grt3,bt-grt1 & 6.057 & 0.000 & 3.959 & 0.000 & 0.010 & 0.004 & 4.283 & 0.863 & 0.123 & 0.697 & 0.003 \\
\hline & $g t 4, b t-g r t 1$ & 6.080 & 0.000 & 4.001 & 0.000 & 0.000 & 0.008 & 4.369 & 0.837 & 0.114 & 0.585 & 0.005 \\
\hline$v-332-1$ e 3 & grt5,bt-grt & 6.079 & 0.000 & 3.980 & 0.000 & 0.006 & 0.010 & 4.324 & 0.950 & 0.130 & 0.515 & 0.006 \\
\hline$v-332-2$ & grt6,bt-grt & 6.041 & 0.000 & 3.986 & 0.000 & 0.007 & 0.002 & 4.378 & 1.063 & 0.120 & 0.398 & 0.006 \\
\hline \multirow[t]{2}{*}{$v-332-9$} & grt7,bt.grt1 & 5.979 & 0.021 & 3.956 & 0.000 & 0.002 & 0.007 & 4.379 & 1.100 & 0.119 & 0.434 & 0.004 \\
\hline & grt8,bt-grt1 & 6.000 & 0.000 & 3.950 & 0.000 & 0.000 & 0.008 & 4.368 & 1.083 & 0.130 & 0.461 & 0.000 \\
\hline \multirow[t]{17}{*}{$v-332-5$} & grt9,bt-grt1 & 6.011 & 0.000 & 3.940 & 0.000 & 0.012 & 0.000 & 4.425 & 1.040 & 0.141 & 0.426 & 0.005 \\
\hline & grt10,bt-grt 1 & 6.018 & 0.000 & 3.942 & 0.000 & 0.004 & 0.008 & 4.382 & 1.085 & 0.124 & 0.430 & 0.007 \\
\hline & grt11,bt-grt1 & 5.965 & 0.035 & 3.933 & 0.000 & 0.010 & 0.006 & 4.425 & 1.071 & 0.142 & 0.406 & 0.007 \\
\hline & grt 12,bt-grt1 & 6.020 & 0.000 & 3.954 & 0.000 & 0.012 & 0.005 & 4.387 & 1.064 & 0.134 & 0.420 & 0.004 \\
\hline & grt 13,bt-grt 1 & 6.014 & 0.000 & 3.982 & 0.000 & 0.011 & 0.007 & 4.358 & 0.902 & 0.120 & 0.605 & 0.000 \\
\hline & grt7,px-grt1 & 6.030 & 0.000 & 3.951 & 0.000 & 0.005 & 0.005 & 4.324 & 1.124 & 0.131 & 0.422 & 0.006 \\
\hline & grt8,px-grt2 & 6.018 & 0.000 & 3.964 & 0.000 & 0.007 & 0.016 & 4.453 & 0.906 & 0.132 & 0.504 & 0.000 \\
\hline & grt9,px-grt2 & 6.014 & 0.000 & 3.969 & 0.000 & 0.014 & 0.008 & 4.411 & 1.031 & 0.122 & 0.429 & 0.001 \\
\hline & grt 10,px-grt2 & 6.038 & 0.000 & 3.990 & 0.000 & 0.005 & 0.013 & 4.321 & 1.031 & 0.115 & 0.485 & 0.002 \\
\hline & $\operatorname{grt} 11, \mathrm{px}$-grt2 & 5.959 & 0.041 & 3.900 & 0.000 & 0.000 & 0.012 & 4.510 & 0.982 & 0.138 & $0.45 t$ & 0.006 \\
\hline & grt12,px-grt2 & 6.007 & 0.000 & 3.974 & 0.000 & 0.001 & 0.007 & 4.463 & 0.995 & 0.116 & 0.436 & 0.002 \\
\hline & grt13,px-grt2 & 6.057 & 0.000 & 3.975 & 0.000 & 0.001 & 0.010 & 4.247 & 1.042 & 0.111 & 0.558 & 0.000 \\
\hline & $\mathrm{grt} 14, p x-\mathrm{grt} 2$ & 6.038 & 0.000 & 3.972 & 0.000 & 0.000 & 0.016 & 4.257 & 1.047 & 0.119 & 0.549 & 0.000 \\
\hline & grt1 1,px-grt1 & 6.040 & 0.000 & 3.972 & 0.000 & 0.006 & 0.014 & 4.258 & 1.005 & 0.125 & 0.577 & 0.003 \\
\hline & grt12,pg-grt1 & 6.036 & 0.000 & 4.000 & 0.000 & 0.013 & 0.007 & 4.319 & 1.052 & 0.123 & 0.445 & 0.006 \\
\hline & $\mathrm{grt13}, \mathrm{pg} \mathrm{grt} 1$ & 5.990 & 0.010 & 3.970 & 0.000 & 0.014 & 0.005 & 4.360 & 1.094 & 0.125 & 0.430 & 0.002 \\
\hline & grt14,pg-grt1 & 6.002 & 0.000 & 3.955 & 0.000 & 0.012 & 0.006 & 4.401 & 1.081 & 0.121 & 0.420 & 0.002 \\
\hline \multirow[t]{4}{*}{$v-332-15$} & grt15, bt-grt2 & 6.061 & 0.000 & 3.967 & 0.000 & 0.000 & 0.014 & 4.261 & 0.811 & 0.133 & 0.747 & 0.006 \\
\hline & grt16,bt-grt2 & 6.026 & 0.000 & 3.981 & 0.000 & 0.009 & 0.017 & 4.379 & 1.043 & 0.115 & 0.428 & 0.003 \\
\hline & grt 17, bt-grt2 & 6.032 & 0.000 & 4.002 & 0.000 & 0.011 & 0.012 & 4.312 & 1.047 & 0.130 & 0.454 & 0.000 \\
\hline & grt 18, bt-grt2 & 6.020 & 0.000 & 3.950 & 0.000 & 0.004 & 0.018 & 4.357 & 0.996 & 0.124 & 0.531 & 0.000 \\
\hline \multirow[t]{3}{*}{$v-332-6$ e 7} & grt 19,bt-grt2 & 5.986 & 0.014 & 3.937 & 0.000 & 0.006 & 0.022 & 4.416 & 1.062 & 0.124 & 0.430 & 0.004 \\
\hline & grt20,bt-grt2 & 6.028 & 0.000 & 3.962 & 0.000 & 0.000 & 0.013 & 4.367 & 1.029 & 0.138 & 0.462 & 0.002 \\
\hline & grt21,bt-grt2 & 6.032 & 0.000 & 3.979 & 0.000 & 0.000 & 0.014 & 4.371 & 1.047 & 0.111 & 0.438 & 0.007 \\
\hline
\end{tabular}


Biotita

\begin{tabular}{|c|c|c|c|c|c|c|c|c|c|c|c|c|c|c|}
\hline Associação & Análise,Perfil & Loc & SIO2 & TIO2 & AL2O3 & FEO & MNO & $M G O$ & CAO & NA2O & $\mathrm{K} 20$ & $C L$ & $F$ & BAO \\
\hline$V-332-4$ & $\mathrm{bt} 1, \mathrm{bt}-\mathrm{gtt} 1$ & betgrt & 36.112 & 4.858 & 13.686 & 18.366 & 0.033 & 11.442 & 0.032 & 0.094 & 9.328 & 0.373 & 1.090 & 0.277 \\
\hline \multirow[t]{2}{*}{$V-332-13$} & bt2,bt-grt1 & núcleo & 35.915 & 4.795 & 13.584 & 18.904 & 0.000 & 11.362 & 0.000 & 0.075 & 9.368 & 0.391 & 1.182 & 0.322 \\
\hline & $\mathrm{bt} 3, \mathrm{bt}-\mathrm{grt} 1$ & bugrt & 36.326 & 5.141 & 13.909 & 18.348 & 0.018 & 11.261 & 0.027 & 0.059 & 9.470 & 0.414 & 0.856 & 0.164 \\
\hline \multirow[t]{2}{*}{$V-332-3$ e 5} & $\mathrm{bt4}, \mathrm{bt}-\mathrm{gtt} 1$ & núcleo & 36.091 & 5.255 & 13.696 & 18.914 & 0.012 & 11.293 & 0.000 & 0.043 & 9.391 & 0.396 & 1.065 & 0.328 \\
\hline & bt5,bt-grt1 & borda & 36.072 & 4.817 & 14.217 & 19.217 & 0.000 & 10.809 & 0.033 & 0.117 & 8.948 & 0.390 & 0.744 & 0.231 \\
\hline \multirow[t]{5}{*}{$V-332-1$ e 9} & bt6,bt-grt1 & núcleo & 35.881 & 5.610 & 13.970 & 19.062 & 0.000 & 10.896 & 0.034 & 0.089 & 9.036 & 0.422 & 0.825 & 0.203 \\
\hline & $b t 7, b t-g r t 1$ & bt/grt & 35.027 & 4.643 & 13.968 & 19.822 & 0.018 & 10.832 & 0.103 & 0.109 & 8.607 & 0.340 & 0.461 & 0.197 \\
\hline & bt8,bt-grt1 & núcleo & 36.202 & 5.403 & 13.878 & 19.400 & 0.030 & 10.967 & 0.009 & 0.064 & 9.304 & 0.378 & 1.031 & 0.321 \\
\hline & bt9,bt-grt1 & interm & 35.339 & 4.942 & 13.951 & 19.216 & 0.035 & 10.687 & 0.019 & 0.096 & 9.166 & 0.429 & 1.009 & 0.276 \\
\hline & bt $10, \mathrm{bt}-\mathrm{grt} 1$ & altera & 35.680 & 4.400 & 14.022 & 18.995 & 0.012 & 11.328 & 0.066 & 0.120 & 9.248 & 0.373 & 0.973 & 0.343 \\
\hline \multirow[t]{6}{*}{$V-332-2$} & btt1,bt-grt1 & inclus & 35.784 & 6.116 & 14.015 & 18.159 & 0.002 & 11.027 & 0.019 & 0.369 & 8.747 & 0.821 & 1.051 & 0.279 \\
\hline & bt12,px-grt2 & inclusi & 36.253 & 5.620 & 13.940 & 18.160 & 0.051 & 11.253 & 0.000 & 0.305 & 8.970 & 0.555 & 0.881 & 0.490 \\
\hline & bt $\{3, p x-g t t 2$ & altera & 36.547 & 4.559 & 13.801 & 16.640 & 0.020 & 12.637 & 0.017 & 0.083 & 9.529 & 0.229 & 0.981 & 0.091 \\
\hline & $\mathrm{bt} 14, \mathrm{px}-\mathrm{grt} 2$ & $b t / p x$ & 35.929 & 4.621 & 13.408 & 19.072 & 0.000 & 11.311 & 0.111 & 0.100 & 8.985 & 0.212 & 0.792 & 0.063 \\
\hline & bt15,px-grt2 & núcieo & 35.621 & 4.898 & 13.574 & 19.154 & 0.028 & 11.332 & 0.037 & 0.047 & 8.856 & 0.170 & 0.818 & 0.140 \\
\hline & bt19,bt-grt2 & btgrt & 35.554 & 5.381 & 13.643 & 18.961 & 0.023 & 11.266 & 0.001 & 0.097 & 9.609 & 0.243 & 0.978 & 0.137 \\
\hline$V-332-7$ & bt20,bt-gtt2 & núcleo & 34.994 & 5.142 & 13.566 & 18.620 & 0.000 & 11.289 & 0.000 & 0.125 & 9.546 & 0.225 & 1.052 & 0.202 \\
\hline \multirow[t]{2}{*}{$V-332-6$} & bt $21, b t-g t 2$ & inclusio & 35.422 & 5.424 & 13.808 & 18.206 & 0.008 & 11.476 & 0.008 & 0.305 & 8.753 & 0.823 & 0.774 & 0.408 \\
\hline & bt22,bt-grt2 & núcleo & 36.346 & 5.166 & 13.714 & 19.266 & 0.022 & 11.328 & 0.000 & 0.067 & 9.496 & 0.241 & 0.865 & 0.129 \\
\hline \multirow[t]{5}{*}{$V-332-15$} & bt23, bt-grt2 & núcleo & 36.146 & 4.864 & 13.549 & 18.840 & 0.012 & 11.283 & 0.013 & 0.107 & 9.559 & 0.228 & 0.928 & 0.006 \\
\hline & bt24,bt-git2 & interm & 35.985 & 4.856 & 13.485 & 19.156 & 0.050 & 11.303 & 0.027 & 0.118 & 9.128 & 0.216 & 0.867 & 0.104 \\
\hline & bt25,bt-grt2 & $\mathrm{b} / \mathrm{grt}$ & 35.639 & 4.466 & 13.593 & 20.976 & 0.000 & 10.025 & 0.038 & 0.062 & 9.064 & 0.247 & 0.703 & 0.095 \\
\hline & bt26,bt-grt2 & núcleo & 36.364 & 5.201 & 13.876 & 19.235 & 0.012 & 10.997 & 0.001 & 0.093 & 9.438 & 0.260 & 1.065 & 0.006 \\
\hline & \multicolumn{14}{|c|}{ Cátions (22 oxigênios, $\mathrm{OH}=0$ ) } \\
\hline Associação & Análise,Perfil & SI & ALIV & ALVI & TI & FE2 & $M N$ & $M G$ & $B A$ & $C A$ & NA & $k$ & $\mathrm{CF}$ & $C C L$ \\
\hline$V-332-4$ & bt1, bt-grt1 & 5.581 & 2.419 & 0.072 & 0.565 & 2.374 & 0.004 & 2.636 & 0.017 & 0.005 & 0.028 & 1.839 & 1.065 & 0.195 \\
\hline \multirow[t]{2}{*}{$V-332-13$} & bt $2, \mathrm{bt}$-grt1 & 5.565 & 2.435 & 0.044 & 0.559 & 2.450 & 0.000 & 2.624 & 0.020 & 0.000 & 0.023 & 1.852 & 1.158 & 0.205 \\
\hline & bt3,bt-grt1 & 5.576 & 2.424 & 0.090 & 0.594 & 2.355 & 0.002 & 2.577 & 0.010 & 0.004 & 0.018 & 1.855 & 0.831 & 0.216 \\
\hline \multirow[t]{2}{*}{$V-332-3$ e 5} & bt 4, bt-grt 1 & 5.547 & 2.453 & 0.026 & 0.608 & 2.431 & 0.002 & 2.588 & 0.020 & 0.000 & 0.013 & 1.841 & 1.035 & 0.206 \\
\hline & $\mathrm{bt} 5, \mathrm{bt}-\mathrm{grt} 1$ & 5.563 & 2.437 & 0.145 & 0.559 & 2.478 & 0.000 & 2.485 & 0.014 & 0.005 & 0.035 & 1.760 & 0.726 & 0.204 \\
\hline \multirow[t]{5}{*}{$V-332-1$ e 9} & bt6,bt-grt1 & 5.518 & 2,482 & 0.048 & 0.649 & 2.452 & 0.000 & 2.498 & 0.012 & 0.006 & 0.027 & 1.773 & 0.802 & 0.220 \\
\hline & bt7,bt-grtt & 5.494 & 2.506 & 0.074 & 0.548 & 2.600 & 0.002 & 2.533 & 0.012 & 0.017 & 0.033 & 1.722 & 0.457 & 0.181 \\
\hline & bt8,bt-grt 1 & 5.538 & 2.462 & 0.038 & 0.622 & 2.482 & 0.004 & 2.501 & 0.019 & 0.001 & 0.019 & 1.816 & 0.998 & 0.196 \\
\hline & bt9,bt-grt1 & 5.519 & 2.481 & 0.085 & 0.580 & 2.510 & 0.005 & 2.488 & 0.017 & 0.003 & 0.029 & 1.826 & 0.997 & 0.227 \\
\hline & bt10,bt-grt1 & 5.537 & 2.463 & 0.099 & 0.514 & 2.465 & 0.002 & 2.620 & 0.021 & 0.011 & 0.036 & 1.831 & 0.955 & 0.196 \\
\hline$V-332-2$ & bt11,bt-grt1 & 5.496 & 2.504 & 0.031 & 0.707 & 2.332 & 0.000 & 2.525 & 0.017 & 0.003 & 0.110 & 1.714 & 1.021 & 0.428 \\
\hline
\end{tabular}




\begin{tabular}{|c|c|c|c|c|c|c|c|c|c|c|c|c|c|c|}
\hline \multirow[t]{6}{*}{ Associação } & Análise Perfil & SI & ALIV & ALVI & TI & FE2 & $M N$ & $M G$ & $B A$ & $C A$ & NA & $k$ & $C F$ & $\mathrm{CCL}$ \\
\hline & bt12,px-grt2 & 5.545 & 2.455 & 0.056 & 0.647 & 2.323 & 0.007 & 2.566 & 0.029 & 0.000 & 0.090 & 1.750 & 0.852 & 0.288 \\
\hline & $b t 13, p x-g r t 2$ & 5.609 & 2.391 & 0.104 & 0.526 & 2.136 & 0.003 & 2.891 & 0.005 & 0.003 & 0.025 & 1.866 & 0.952 & 0.119 \\
\hline & bt14,px-grt2 & 5.594 & 2.406 & 0.052 & 0.541 & 2.483 & 0.000 & 2.625 & 0.004 & 0.019 & 0.030 & 1.785 & 0.780 & 0.112 \\
\hline & bt15,px-grt2 & 5.545 & 2.455 & 0.033 & 0.573 & 2.493 & 0.004 & 2.630 & 0.009 & 0.006 & 0.014 & 1.759 & 0.805 & 0.090 \\
\hline & bt $19, b t-g r t 2$ & 5.498 & 2.484 & 0.000 & 0.626 & 2.452 & 0.003 & 2.597 & 0.008 & 0.000 & 0.029 & 1.896 & 0.956 & 0.127 \\
\hline$V-332-7$ & bt20,bt-grt2 & 5.483 & 2.503 & 0.000 & 0.606 & 2.440 & 0.000 & 2.637 & 0.012 & 0.000 & 0.038 & 1.908 & 1.043 & 0.120 \\
\hline \multirow[t]{2}{*}{$V-332-6$} & bt21,bt-grt2 & 5.495 & 2.505 & 0.018 & 0.633 & 2.362 & 0.001 & 2.654 & 0.025 & 0.001 & 0.092 & 1.732 & 0.759 & 0.433 \\
\hline & bt22,bt-grt2 & 5.557 & 2.443 & 0.026 & 0.594 & 2.463 & 0.003 & 2.582 & 0.008 & 0.000 & 0.020 & 1.852 & 0.836 & 0.125 \\
\hline \multirow[t]{4}{*}{$V-332-15$} & bt23,bt-grt2 & 5.585 & 2.415 & 0.051 & 0.565 & 2.435 & 0.002 & 2.599 & 0.000 & 0.002 & 0.032 & 1.884 & 0.907 & 0.119 \\
\hline & bt24,bt-grt2 & 5.574 & 2.426 & 0.034 & 0.566 & 2.481 & 0.007 & 2.610 & 0.006 & 0.004 & 0.035 & 1.804 & 0.849 & 0.113 \\
\hline & bt25,bt-grt2 & 5.583 & 2.417 & 0.091 & 0.526 & 2.748 & 0.000 & 2.341 & 0.006 & 0.006 & 0.019 & 1.811 & 0.697 & 0.131 \\
\hline & bt26;bt-grt2 & 5.567 & 2.433 & 0.069 & 0.599 & 2.463 & 0.002 & 2.510 & 0.000 & 0.000 & 0.028 & 1.843 & 1.031 & 0.135 \\
\hline \multicolumn{15}{|l|}{$\begin{array}{c}\text { Ortopiroxêno } \\
\text { Associacão }\end{array}$} \\
\hline \multirow[t]{6}{*}{ Associação } & Análise,Perfil & Loc & SIO2 & TIO2 & AL2O3 & FEO & MNO & $M G O$ & CAO & NA2O & $K 20$ & CR2O3 & NIO & TOTAL \\
\hline & $p \times 1, p x-g r t 1$ & borda & 49.542 & 0.169 & 0.837 & 33.987 & 0.345 & 13.628 & 0.368 & 0.000 & 0.000 & 0.007 & 0.000 & 98.883 \\
\hline & $p \times 2, p x-g r t 1$ & núcleo & 49.534 & 0.104 & 0.962 & 34.280 & 0.351 & 13.603 & 0.455 & 0.036 & 0.000 & 0.032 & 0.000 & 99.357 \\
\hline & px3,px-grt1 & núcleo & 48.963 & 0.064 & 1.321 & 33.902 & 0.374 & 13.608 & 0.379 & 0.004 & 0.011 & 0.053 & 0.000 & 98.679 \\
\hline & $p \times 4, p x-g r t 1$ & nícleo & 48.985 & 0.000 & 1.853 & 33.360 & 0.330 & 13.558 & 0.367 & 0.027 & 0.018 & 0.000 & 0.000 & 98.498 \\
\hline & $p \times 4$, rep2 & กúcleo & 49.118 & 0.161 & 1.512 & 33.681 & 0.347 & 13.371 & 0.418 & 0.000 & 0.016 & 0.010 & 0.000 & 98.634 \\
\hline \multirow{5}{*}{$\begin{array}{l}\text { V-332- } \\
1,2,3,5,6,7,9\end{array}$} & & & & & & & & & & & & & & \\
\hline & px5,px-grt1 & núcleo & 49.061 & 0.132 & 1.237 & 33.601 & 0.259 & 13.865 & 0.371 & 0.002 & 0.022 & 0.103 & 0.000 & 98.653 \\
\hline & $p \times 6, p x-g r t 1$ & borda & 49.291 & 0.087 & 1.187 & 33.175 & 0.273 & 14.174 & 0.370 & 0.005 & 0.000 & 0.068 & 0.000 & 98.630 \\
\hline & $p \times 7, p x-g r t 1$ & núcleo & 49.228 & 0.102 & 1.085 & 33.977 & 0.325 & 13.703 & 0.451 & 0.001 & 0.000 & 0.000 & 0.000 & 98.872 \\
\hline & px9,px-grt1 & interm & 49.283 & 0.125 & 1.318 & 34.277 & 0.402 & 13.320 & 0.471 & 0.000 & 0.000 & 0.034 & 0.000 & 99.230 \\
\hline \multirow[t]{10}{*}{$V-332-4,13,15$} & $\mathrm{p} \times 10, \mathrm{px}-\mathrm{grt} 1$ & $\mathrm{px} / \mathrm{grt}$ & 49.336 & 0.116 & 1.347 & 34.094 & 0.346 & 13.132 & 0.339 & 0.031 & 0.003 & 0.052 & 0.000 & 98.796 \\
\hline & $p \times 11, p x-g r t 1$ & núcleo & 49.032 & 0.000 & 1.777 & 34.263 & 0.327 & 12.901 & 0.438 & 0.060 & 0.139 & 0.067 & 0.000 & 99.004 \\
\hline & $p \times 1, p x-g r t 2$ & borda & 49.239 & 0.127 & 1.083 & 33.718 & 0.292 & 13.941 & 0.452 & 0.051 & 0.022 & 0.073 & 0.000 & 98.998 \\
\hline & $p \times 2 r, p \times-g r t 2$ & borda & 49.309 & 0.123 & 1.185 & 34.237 & 0.306 & 13.723 & 0.362 & 0.020 & 0.000 & 0.020 & 0.000 & 99.285 \\
\hline & $p \times 3, p \times-g r t 2$ & núcleo & 48.683 & 0.137 & 1.564 & 33.817 & 0.384 & 13.619 & 0.398 & 0.011 & 0.000 & 0.000 & 0.000 & 98.613 \\
\hline & $p \times 4, p \times-g r t 2$ & borda & 49.326 & 0.082 & 1.219 & 33.778 & 0.325 & 13.821 & 0.373 & 0.008 & 0.026 & 0.080 & 0.000 & 99.038 \\
\hline & $p \times 5, p x-g r t 2$ & pxigrt & 49.633 & 0.054 & 1.032 & 32.495 & 0.267 & 14.911 & 0.340 & 0.000 & 0.011 & 0.071 & 0.000 & 98.814 \\
\hline & $p \times 6, p x-g r t 2$ & núcleo & 48.936 & 0.075 & 1.505 & 33.962 & 0.297 & 13.245 & 0.460 & 0.047 & 0.000 & 0.051 & 0.000 & 98.578 \\
\hline & $\mathrm{p} \times 7, \mathrm{px}-\mathrm{grt} 2$ & interm & 49.890 & 0.010 & 1.090 & 32.821 & 0.212 & 14.133 & 0.371 & 0.014 & 0.000 & 0.055 & 0.000 & 98.596 \\
\hline & $p \times 8, p x-g r t 2$ & borda & 48.695 & 0.055 & 1.447 & 33.922 & 0.329 & 13.086 & 0.409 & 0.014 & 0.000 & 0.071 & 0.000 & 98.028 \\
\hline
\end{tabular}


Associação Análise,Perfil

$p \times 1, p \times$-grt 1 $p \times 2, p x-g r t 1$

$\mathrm{p} \times 3, \mathrm{px}-\mathrm{grt} 1$

$\mathrm{px} 4, \mathrm{px}-\mathrm{grt} 1$

$p \times 4$, rep2

V-332.

$1,2,3,5,6,7,9$

$p \times 5, p \times-g r t 1$

px6,px-grt1

px7,px-grt1

px9.px-grt1

pxt0,px-grt1

$p \times\{1, p x-g r t 1$

$p \times 1, p x-g r t 2$

$p \times 2 r, p x-g r t 2$

px3,px-grt2

$p \times 4, p x-g r t 2$

$\mathrm{px} 5, \mathrm{px}-\mathrm{grt2}$

$p \times 6, p \times-g r t 2$

$p \times 7, p x-g r t 2$

$p \times 8, p x-g r t 2$

\section{Plagioclásio}

\section{Associaca}

V-332-

$1,2,3,5,6,7,9$

V-332-4,13,15 pg2,pg-grt

pg2,pg-grt

pg4,pg-grt

pg5,pertita

og6, pertita

fd7, pertitico

Cátions (6 oxigênios)

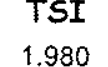

1.980
1.970

1.959

1.959
1.967

1.967

1.960
1.965

1.965

1.965

1.976
1.959

1.960

1.961
1.948

1.948
1.964

1.967

1.962

1.989

1.965

TAL

0.020

0.030

0.041

0.041

MIAL

$0.019 \quad 0.005$

MIFE2 M1CR

$\begin{array}{lllll}0.019 & 0.005 & 0.163 & 0.000\end{array}$

$\begin{array}{llll}0.021 & 0.002 & 0.164 & 0.002\end{array}$

0.046

0.000

0.146

0.000

MIMG M2FE2 M2MN M2CA

M2NA M2K

$\begin{array}{lllllll}0.812 & 0.973 & 0.012 & 0.016 & 0.000 & 0.000\end{array}$

$\begin{array}{llllll}0.812 & 0.970 & 0.012 & 0.019 & 0.003 & 0.000\end{array}$

0.040

0.035

$0.018 \quad 0.004$

$0.021 \quad 0.003$

0.158

$\begin{array}{lll}0.808 & 0.970 & 0.011\end{array}$

0.016

0.035

0.024

$0.149 \quad 0.003$

$\begin{array}{lll}0.798 & 0.969 & 0.012\end{array}$

$\begin{array}{lll}0.018 & 0.000 & 0.001\end{array}$

0.040

0.039

0.052

0.036

0.033
0.038

0.011

0.035

0.043

0.010
0.016

0.021

$0.021 \quad 0.002$

$\begin{array}{llllllllll}0.015 & 0.002 & 0.101 & 0.002 & 0.881 & 0.976 & 0.009 & 0.014 & 0.000 & 0.001 \\ 0.033 & 0.002 & 0.172 & 0.002 & 0.791 & 0.967 & 0.010 & 0.020 & 0.004 & 0.000\end{array}$

$0.132 \quad 0.002$

$\begin{array}{lll}0.826 & 0.974 & 0.009\end{array}$

$\begin{array}{lll}0.016 & 0.000 \quad 0.001\end{array}$

$\begin{array}{lllllllll}0.165 & 0.000 & 0.816 & 0.970 & 0.011 & 0.019 & 0.000 & 0.000 \\ 0.177 & 0.001 & 0.792 & 0.966 & 0.014 & 0.020 & 0.000 & 0.000\end{array}$

$\begin{array}{lllllllll}0.177 & 0.001 & 0.792 & 0.966 & 0.014 & 0.020 & 0.000 & 0.000\end{array}$

$\begin{array}{lllllllll}0.003 & 0.171 & 0.002 & 0.784 & 0.971 & 0.012 & 0.015 & 0.002 & 0.000\end{array}$

$\begin{array}{lllllllll}0.000 & 0.187 & 0.002 & 0.768 & 0.958 & 0.011 & 0.019 & 0.005 & 0.007 \\ 0.004 & 0.156 & 0.002 & 0.827 & 0.966 & 0.010 & 0.019 & 0.004 & 0.001\end{array}$

$\begin{array}{lllllllll}0.004 & 0.156 & 0.002 & 0.827 & 0.366 & 0.010 & 0.019 & 0.004 & 0.001\end{array}$

$\begin{array}{lllllllll}0.004 & 0.166 & 0.001 & 0.814 & 0.973 & 0.010 & 0.015 & 0.002 & 0.000\end{array}$

$\begin{array}{lllllllll}0.002 & 0.162 & 0.000 & 0.8\} 2 & 0.969 & 0.013 & 0.017 & 0.001 & 0.000\end{array}$

$\begin{array}{lllllllll}0.040 & 0.000 & 0.118 & 0.002 & 0.840 & 0.976 & 0.007 & 0.016 & 0.001\end{array}$

$\begin{array}{llllllllll}0.034 & 0.002 & 0.175 & 0.002 & 0.787 & 0.970 & 0.011 & 0.018 & 0.001 & 0.000 \\ & & & & & & & \end{array}$

\section{Loc}

SIO2

$\mathrm{pg} / \mathrm{grt}$

borda

borda

pertita

feld
59.626

59.688
60.478

60.240

61.019

$\begin{array}{ll}62.881 & 0.000\end{array}$

$64.480 \quad 0.000$
TIO2 AL2O3 FE2O3 MNO

CAO BAO NA2O K2O

25.136

0.155

0.017

$\begin{array}{lll}6.810 & 0.002 & 7.649\end{array}$

0.100

$$
\begin{aligned}
& 24.951 \\
& 24.755
\end{aligned}
$$

$\begin{array}{lll}6.588 & 0.002 & 7.418\end{array}$

$\begin{array}{lll}6.654 & 0.027 & 7.691\end{array}$

$\begin{array}{lll}6.681 & 0.002 & 7.633 \\ 4.974 & 0.117 & 5.127\end{array}$

$\begin{array}{lll}3.188 & 0.230 & 3.596\end{array}$

$\begin{array}{lll}0.174 & 0.437 & 1.249\end{array}$ $\begin{array}{llll}0.151 & 0.000 & 0.042 & 100.006\end{array}$

$\begin{array}{llll}0.203 & 0.005 & 0.056 & 99.737\end{array}$

$\begin{array}{llll}5.514 & 0.000 & 0.052 & 100.111\end{array}$

$\begin{array}{llll}8.772 & 0.000 & 0.093 & 100.439\end{array}$ 


\begin{tabular}{|c|c|c|c|c|c|c|c|c|c|c|c|c|c|}
\hline \multicolumn{11}{|c|}{ Cátions (32 oxigênios) } & \multicolumn{3}{|c|}{ Componentes } \\
\hline $\begin{array}{l}\text { Associação } \\
\text { V-332. }\end{array}$ & Análise,Perfil & SI & $A L$ & FE3 & $T I$ & $M N$ & $B A$ & $C A$ & $N A$ & $k$ & $A B$ & AN & $O R$ \\
\hline \multirow{8}{*}{$\begin{array}{l}V-332- \\
1,2,3,5,6,7,9 \\
V-332-4,13,15\end{array}$} & & & & & & & & & & & & & \\
\hline & $\begin{array}{l}\text { pg1,pg-grt } \\
\text { pg2,pg-grt }\end{array}$ & $\begin{array}{l}10.6 / 8 \\
10.720\end{array}$ & 5.301 & 0.021 & 0.000 & 0.003 & 0.000 & 1.307 & 2.656 & 0.023 & 66.600 & 32.800 & 0.600 \\
\hline & $\begin{array}{l}\text { pg2,pg-grt } \\
\text { pg3,pg-grt }\end{array}$ & $\begin{array}{l}10.720 \\
10.767\end{array}$ & 5.277 & 0.015 & 0.000 & 0.001 & 0.000 & 1.268 & 2.583 & 0.087 & 65.600 & 32.200 & 2.200 \\
\hline & $\begin{array}{l}\text { pg3,pg-grt } \\
\text { pg4,pg-grt }\end{array}$ & $\begin{array}{l}10.767 \\
10.755\end{array}$ & 5.195 & 0.021 & 0.007 & 0.000 & 0.002 & 1.269 & 2.655 & 0.034 & 67.100 & 32.100 & 0.900 \\
\hline & pg4,pg-grt & 10.755 & 5.232 & 0.004 & 0.000 & 0.000 & 0.000 & 1.278 & 2.642 & 0.046 & 66.600 & 32.200 & 1.200 \\
\hline & pg5,pertita & 11.025 & 4.942 & 0.008 & 0.003 & 0.000 & 0.008 & 0.963 & 1.796 & 1.271 & 44.600 & 23.900 & 31.500 \\
\hline & pg6,pertita & 11.389 & 4.608 & 0.005 & 0.000 & 0.006 & 0.018 & 0.619 & 1.263 & 2.027 & 32.300 & 15.800 & 51.900 \\
\hline & $\mathrm{fd} 7$,pertitico & 11.913 & 4.072 & 0.005 & 0.000 & 0.000 & 0.032 & 0.034 & 0.447 & 3.505 & 11.200 & 0.900 & 87.900 \\
\hline \multicolumn{14}{|l|}{ Ilmenita } \\
\hline \multirow[t]{6}{*}{ Associação } & Análise,Perfil & Loc & SIO2 & TIO2 & AL2O3 & $\mathrm{CR} 2 \mathrm{O} 3$ & FEO & MNO & $M G O$ & $C A O$ & NB2O5 & TOTAL & \\
\hline & opa1,b-g & incl-bt & 0.010 & 51.059 & 0.030 & 0.000 & 46.024 & 0.527 & 0.037 & 0.000 & 0.197 & 97.884 & \\
\hline & opa2,b-g & ill/grt & 0.006 & 49.344 & 0.000 & 0.100 & 46.018 & 0.558 & 0.012 & 0.000 & 0.217 & 96.255 & \\
\hline & opa1,c-g & in/grt-px & 0.024 & 48.991 & 0.026 & 0.092 & 47.149 & 0.321 & 0.063 & 0.007 & 0.105 & 96.778 & \\
\hline & opa2,c-g & $i 11 / p x$ & 0.000 & 51.054 & 0.023 & 0.104 & 46.776 & 0.307 & 0.020 & 0.010 & 0.174 & 98.468 & \\
\hline & \multicolumn{13}{|c|}{ Cátions (6 oxigênios) } \\
\hline \multirow[t]{5}{*}{ Associação } & Análise,Perfil & $S I$ & TI & $A L$ & FE2 & FE3 & $C R$ & $M N$ & $M G$ & $C A$ & NB & & \\
\hline & opa1,b-g & 0.0003 & 1.984 & 0.001 & 1.969 & 0.019 & 0.000 & 0.023 & 0.002 & 0.000 & 0.004 & & \\
\hline & opa2,b-g & 0.0000 & 1.960 & 0.000 & 1.946 & 0.086 & 0.004 & 0.024 & 0.000 & 0.000 & 0.005 & & \\
\hline & opa1,c-g & 0.0012 & 1.942 & 0.001 & 1.931 & 0.147 & 0.003 & 0.014 & 0.004 & 0.000 & 0.002 & & \\
\hline & opa2,c-g & 0.0000 & 1.976 & 0.001 & 1.969 & 0.043 & 0.004 & 0.013 & 0.001 & 0.000 & 0.004 & & \\
\hline
\end{tabular}

Lâmina $G r-15$, gnaisse quartzo-feldspático

Granada

$\begin{array}{ll}\text { Associação } & \begin{array}{c}\text { Análise,Perfil } \\ \text { grt1,btverde-grt }\end{array} \\ & \text { grt2,btverde-grt } \\ \text { Gr-15-9 } & \text { grt3,btverde-grt } \\ \text { Gr-15-1,1A } & \text { grt4,btverde-grt } \\ & \text { grt5,btsimp-grt1 } \\ & \text { grt6,btsimp-grt1 } \\ \text { Gr-15-4 } & \text { grt7,btsimp-grt1 } \\ \text { Gr-15-3 } & \text { grt8,btsimp-grt } \\ & \text { grt9,btsimp grt1 }\end{array}$

$\begin{array}{cc}\text { Loc } & \text { SIO2 } \\ \text { núcleo } & 37.576 \\ \text { núcleo } & 37.183 \\ \text { gríbtv } & 36.402 \\ \text { núcleo } & 37.425 \\ \text { interm } & 37.344 \\ \text { núcleo } & 37.433 \\ \text { gt/bt } & 36.892 \\ \text { núcleo } & 37.216 \\ \text { núcleo } & 37.379\end{array}$

AL2O3

$20.869 \quad 0.026$

FEO

MNO

MGO CAO NA2O $20.966 \quad 0.070$ $20.176 \quad 0.075$ 32.395 MNO $\begin{array}{lll}3.171 & 3.646 & 0.012\end{array}$

CR2O3 Y2O3 BAO TOTAL $20.783 \quad 0.024$ $33.281 \quad 1.847$ $20.962 \quad 0.009$ $33.902 \quad 2.793$ $\begin{array}{lll}3.325 & 3.153 & 0.010\end{array}$

$0.000 \quad 0.372$
$0.000 \quad 100.038$ $\begin{array}{lllllllll}32.488 & 1.943 & 3.180 & 3.806 & 0.019 & 0.000 & 0.243 & 0.021 & 99.932\end{array}$ $\begin{array}{lllllllllll}20.383 & 0.074 & 33.154 & 2.916 & 1.780 & 3.256 & 0.013 & 0.025 & 0.190 & 0.000 & 99.377\end{array}$ $\begin{array}{lllllllllll}20.816 & 0.045 & 31.909 & 1.761 & 1.780 & 3.256 & 0.013 & 0.005 & 0.162 & 0.026 & 98.661\end{array}$ $\begin{array}{lllllllllll}20.816 & 0.045 & 31.999 & 1.701 & 3.109 & 3.487 & 0.042 & 0.000 & 0.231 & 0.056 & 0.702\end{array}$ $\begin{array}{lllllllllll}20.764 & 0.062 & 32.029 & 1.781 & 3.352 & 3.879 & 0.038 & 0.017 & 0.258 & 0.000 & 99.559\end{array}$ 


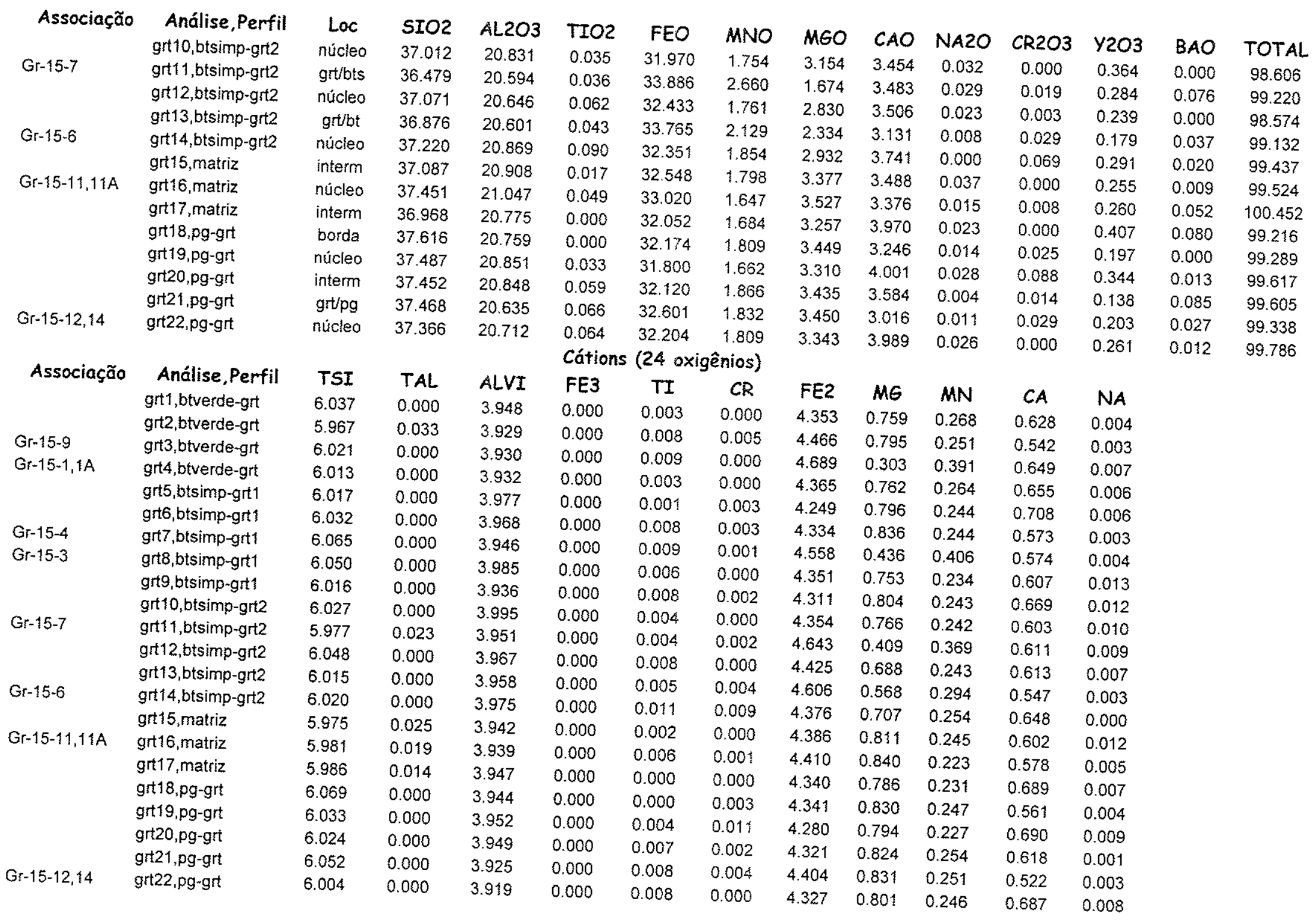


Biotita

\begin{tabular}{|c|c|c|c|c|c|c|c|c|c|c|c|c|c|c|c|}
\hline \multirow[t]{2}{*}{ Associação } & Análise,Perfil & Loc & SIO2 & TIO2 & AL2O3 & FEO & MNO & $M G O$ & $C A O$ & NAZO & $\mathrm{K} 20$ & $\mathrm{Cl}$ & $\mathrm{F}$ & $B A O$ & TOTAL \\
\hline & bt1,matriz & borda & 34.447 & 1.615 & 18.037 & 22.688 & 0.063 & 7.670 & 0.012 & 0.062 & 9.350 & 0.188 & 0.459 & 0.171 & 94.762 \\
\hline \multicolumn{12}{|l|}{$\mathrm{Gr}-15$} & 0.201 & & & \\
\hline \multirow[t]{2}{*}{$1 \mathrm{~A}, 6 \mathrm{~A}, 11 \mathrm{~A}$} & bt3,matriz & núcleo & 34.508 & 1.686 & 17.620 & 23.424 & 0.071 & 7.750 & 0.007 & 0.068 & 9.287 & 0.201 & 0.401 & 0.079 & 95.102 \\
\hline & bt 4, btverde-grt & btv/grt & 33.453 & 0.678 & 17.750 & 24.381 & 0.048 & 8.624 & 0.069 & 0.068 & 8.097 & 0.195 & 0.765 & 0.162 & 94.290 \\
\hline \multirow[t]{3}{*}{$\mathrm{Gr}-15-9$} & bt5, btverde-grt & núcleo & 34.463 & 0.675 & 17.602 & 23.628 & 0.030 & 8.646 & 0.032 & 0.047 & 8.934 & 0.224 & 0.590 & 0.023 & 94.894 \\
\hline & bt6,btverde-grt & borda & 33.323 & 0.644 & 17.016 & 24.480 & 0.033 & 8.401 & 0.080 & 0.061 & 8.506 & 0.206 & 0.647 & 0.005 & 93.402 \\
\hline & bt7, btverde-grt & bt/grt & 33.515 & 2.809 & 16.665 & 23.762 & 0.109 & 6.832 & 0.037 & 0.053 & 8.976 & 0.317 & 0.619 & 0.061 & 93.755 \\
\hline Gr-15-12,1 & bt8,btverde-grt & núcleo & 33.992 & 3.176 & 16.719 & 23.441 & 0.064 & 7.029 & 0.045 & 0.058 & 8.938 & 0.310 & 0.684 & 0.142 & 94.598 \\
\hline$G r-15-4$ & bt9,btsimp-grt1 & $\mathrm{bt} / \mathrm{grt}$ & 34.275 & 2.216 & 16.802 & 23.905 & 0.051 & 7.542 & 0.014 & 0.058 & 9.516 & 0.219 & 0.712 & 0.013 & 95.323 \\
\hline $\mathrm{Gr}-15-3$ & bt10,btsimp-grt & núcleo & 34.410 & 2.288 & 16.814 & 23.993 & 0.046 & 7.400 & 0.000 & 0.078 & 9.432 & 0.228 & 0.677 & 0.126 & 95.492 \\
\hline \multirow[t]{8}{*}{ Gr-15-7 } & bt11,btsimp-grt2 & $\mathrm{bt} / \mathrm{gr}$ & 33.556 & 1.637 & 17.606 & 23.630 & 0.054 & 7.650 & 0.094 & 0.092 & 8.562 & 0.188 & 0.425 & 0.034 & 93.528 \\
\hline & bt12,btsimp-grt2 & núcleo & 33.627 & 1.527 & 17.748 & 22.739 & 0.064 & 7.620 & 0.123 & 0.120 & 8.960 & 0.198 & 0.743 & 0.000 & 93.469 \\
\hline & bt13,btsimp-grt2 & borda & 33.326 & 1.501 & 16.909 & 23.578 & 0.066 & 7.689 & 0.107 & 0.089 & 8.324 & 0.160 & 0.475 & 0.028 & 92.252 \\
\hline & bt14,btsimp-grt2 & $\mathrm{b} t \mathrm{grt}$ & 32.591 & 0.530 & 17.029 & 23.200 & 0.072 & 8.909 & 0.193 & 0.078 & 7.551 & 0.112 & 0.423 & 0.023 & 90.711 \\
\hline & bt15,btsimp-grt2 & borda & 33.533 & 0.469 & 17.587 & 21.918 & 0.050 & 8.745 & 0.148 & 0.075 & 8.439 & 0.145 & 0.756 & 0.047 & 91.912 \\
\hline & bt17,btsimp-grt3 & interm & 34.164 & 1.369 & 17.490 & 22.934 & 0.084 & 8.080 & 0.046 & 0.073 & 9.246 & 0.183 & 0.684 & 0.010 & 94.363 \\
\hline & bt18,btsimp-grt3 & borda & 34.421 & 1.347 & 18.119 & 22.915 & 0.043 & 7.740 & 0.068 & 0.055 & 9.412 & 0.180 & 0.697 & 0.102 & 95.099 \\
\hline & \multicolumn{15}{|c|}{ Cátions (22 oxigênios, $\mathrm{OH}=0$ ) } \\
\hline \multirow[t]{2}{*}{ Associação } & Análise,Perfil & SI & ALIV & ALVI & TI & FE2 & $M N$ & $M G$ & $B A$ & $C A$ & NA & K & CF & $\mathrm{CCl}$ & \\
\hline & bt1, matriz & 5.421 & 2.579 & 0.764 & 0.191 & 2.986 & 0.008 & 1.800 & 0.011 & 0.002 & 0.019 & 1.877 & 0.457 & 0.100 & \\
\hline \multicolumn{16}{|l|}{ Gr-15- } \\
\hline \multirow[t]{2}{*}{$1 \mathrm{~A}, 6 \mathrm{~A}, 11 \mathrm{~A}$} & bt3, matriz & 5.425 & 2.575 & 0.687 & 0.199 & 3.080 & 0.009 & 1.816 & 0.005 & 0.001 & 0.021 & 1.863 & 0.399 & 0.107 & \\
\hline & bt 4 , btverde-grt & 5.334 & 2.666 & 0.667 & 0.081 & 3.251 & 0.006 & 2.050 & 0.010 & 0.012 & 0.021 & 1.647 & 0.772 & 0.105 & \\
\hline \multirow[t]{3}{*}{$G r-15-9$} & bt5, btverde-grt & 5.434 & 2.566 & 0.702 & 0.080 & 3.116 & 0.004 & 2.032 & 0.001 & 0.005 & 0.014 & 1.797 & 0.588 & 0.120 & \\
\hline & bt6, btverde-grt & 5.379 & 2.621 & 0.613 & 0.078 & 3.304 & 0.005 & 2.021 & 0.000 & 0.014 & 0.019 & 1.752 & 0.661 & 0.113 & \\
\hline & bt7,btverde-grt & 5.393 & 2.607 & 0.551 & 0.340 & 3.198 & 0.015 & 1.639 & 0.004 & 0.006 & 0.017 & $\{.843$ & 0.630 & 0.173 & \\
\hline$G r-15-12,1$ & bt8, btverde-grt & 5.406 & 2.594 & 0.538 & 0.380 & 3.118 & 0.009 & 1.667 & 0.009 & 0.008 & 0.018 & 1.814 & 0.688 & 0.167 & \\
\hline Gr-15-4 & $b t 9, b t s i m p-g r t 1$ & 5.424 & 2.576 & 0.555 & 0.264 & 3.164 & 0.007 & 1.779 & 0.001 & 0.002 & 0.018 & $\{.921$ & 0.713 & 0.118 & \\
\hline Gr-15-3 & bt10,btsimp-grt 1 & 5.436 & 2.564 & 0.564 & 0.272 & 3.170 & 0.006 & 1.743 & 0.008 & 0.000 & 0.024 & 1.901 & 0.676 & 0.122 & \\
\hline \multirow[t]{5}{*}{$G=15-7$} & bt11,btsimp-grt2 & 5.366 & 2.634 & 0.681 & 0.197 & 3.160 & 0.007 & 1.824 & 0.002 & 0.016 & 0.029 & 1.747 & 0.430 & 0.102 & \\
\hline & bt12,btsimp-grt2 & 5.387 & 2.613 & 0.735 & 0.184 & 3.046 & 0.009 & 1.820 & 0.000 & 0.021 & 0.037 & 1.831 & 0.753 & 0.108 & \\
\hline & bt13, btsimp-gtt2 & 5.408 & 2.592 & 0.640 & 0.183 & 3.200 & 0.009 & 1.860 & 0.002 & 0.019 & 0.028 & 1.723 & 0.488 & 0.088 & \\
\hline & $b \neq 14$, btsimp-grt2 & 5.353 & 2.647 & 0.647 & 0.065 & 3.187 & 0.010 & 2.181 & 0.001 & 0.034 & 0.025 & 1.582 & 0.439 & 0.062 & \\
\hline & bt15,btsimp-grt2 & 5.428 & 2.572 & 0.781 & 0.057 & 2.967 & 0.007 & 2.110 & 0.003 & 0.026 & 0.024 & 1.743 & 0.774 & 0.080 & \\
\hline
\end{tabular}




\begin{tabular}{|c|c|c|c|c|c|c|c|c|c|c|c|c|c|c|}
\hline \multirow[t]{3}{*}{ Associação } & Análise Perfil & SI & ALIV & ALVI & TI & FE2 & $M N$ & $M G$ & $B A$ & $C A$ & NA & K & $C F$ & $\mathrm{CCl}$ \\
\hline & bt17, btsimp-grt3 & 5.422 & 2.578 & 0.691 & 0.163 & 3.044 & 0.011 & 1.912 & 0.001 & 0.008 & 0.022 & 1.872 & 0.687 & 0.098 \\
\hline & bt 18, btsimp-grt3 & 5.416 & 2.584 & 0.774 & 0.159 & 3.015 & 0.006 & 1.816 & 0.006 & 0.011 & 0.017 & 1.889 & 0.694 & 0.096 \\
\hline
\end{tabular}

\section{Plagioclásio}

\begin{tabular}{|c|c|c|c|c|c|c|c|c|c|c|c|c|c|}
\hline Associação & Análise, Perfil & LoC & SIO2 & TIO2 & AL2O3 & FE2O3 & FEO & MNO & CAO & $B A O$ & $\mathrm{NA2O}$ & $\mathrm{K} 20$ & $C L$ \\
\hline Gr-15 & pg1,btsimp-grt 1 & simple1 & 60.742 & 0.071 & 24.590 & 0.281 & 0.000 & 0.000 & 6.075 & 0.004 & 8.051 & 0.124 & 0.013 \\
\hline Gr-15-7 & pg2,btsimp-grt2 & simple2 & 59.748 & 0.000 & 24.885 & 0.250 & 0.000 & 0.002 & 5.594 & 0.006 & 8.197 & 0.132 & 0.000 \\
\hline Gr-15 & pg3,btsimp-grt2 & aredor-grt & 61.956 & 0.022 & 24.055 & 0.290 & 0.000 & 0.027 & 5.302 & 0.000 & 8.562 & 0.122 & 0.000 \\
\hline $\mathrm{Gr}-15$ & mic1,btsimp-grt2 & bts-grt2 & 64.157 & 0.006 & 18.514 & 0.000 & 0.000 & 0.000 & 0.014 & 0.202 & 1.184 & 15.662 & 0.000 \\
\hline$G r-15$ & pg4,btsimp-grt3 & bts-gri3 & 60.852 & 0.022 & 24.324 & 0.345 & 0.000 & 0.000 & 5.992 & 0.052 & 8.317 & 0.131 & 0.008 \\
\hline Gr- $15-1 A, 4,9$ & pg5,pg-grt & $\mathrm{pg} / \mathrm{gr}$ & 60.856 & 0.002 & 24.576 & 0.240 & 0.000 & 0.033 & 5.968 & 0.016 & 8.296 & $0.11\}$ & 0.013 \\
\hline Gr 15 & pg6,pg-grt & núcleo & 61.127 & 0.067 & 24.081 & 0.064 & 0.000 & 0.017 & 5.871 & 0.147 & 8.326 & 0.154 & 0.000 \\
\hline \multicolumn{14}{|c|}{$\begin{array}{l}\text { Gr-15- } \\
1,3,11,11 A, 12,6,\end{array}$} \\
\hline $6 \mathrm{~A}, 14$ & pg7,pg grt & borda & 61.308 & 0.000 & 24.137 & 0.032 & 0.000 & 0.029 & 5.788 & 0.038 & 8.282 & 0.192 & 0.018 \\
\hline Grm15 & pg8,pg-grt & núcleo & 60.870 & 0.000 & 24.100 & 0.047 & 0.000 & 0.000 & 5.866 & 0.086 & 8.106 & 0.228 & 0.000 \\
\hline \multicolumn{11}{|c|}{ Cátions (32 oxigênios) } & \multicolumn{3}{|c|}{ Componentes } \\
\hline Associação & Análise,Perfil & SI & $A L$ & FE3 & $T I$ & $M N$ & $B A$ & $C A$ & $N A$ & K & $A B$ & $A N$ & OR \\
\hline Gr-15 & pg1,btsimp-grt1 & 10.810 & 5.154 & 0.038 & 0.010 & 0.000 & 0.000 & 1.158 & 2.778 & 0.028 & 70.100 & 29.200 & 0.700 \\
\hline Gr-15-7 & pg2, btsimp grt2 & 10.752 & 5.274 & 0.034 & 0.000 & 0.000 & 0.000 & 1.079 & 2.860 & 0.030 & 72.100 & 27.200 & 0.800 \\
\hline$G r-15$ & pg3,btsimp-grt2 & 10.960 & 5.011 & 0.039 & 0.003 & 0.004 & 0.000 & 1.005 & 2.937 & 0.028 & 74.000 & 25.300 & 0.700 \\
\hline$G r-15$ & mic1, btsimp-grt2 & 11.915 & 4.049 & 0.000 & 0.001 & 0.000 & 0.015 & 0.003 & 0.426 & 3.711 & 10.300 & 0.100 & 89.600 \\
\hline $\mathrm{Gr}-15$ & pg4,btsimp-grt3 & 10.835 & 5.100 & 0.046 & 0.003 & 0.000 & 0.004 & 1.143 & 2.871 & 0.030 & 71.000 & 28.300 & 0.700 \\
\hline$G r-15-1 A, 4,9$ & pg5,pg grt & 10.819 & 5.145 & 0.032 & 0.000 & 0.005 & 0.001 & 1.137 & 2.860 & 0.026 & 71.100 & 28.300 & 0.600 \\
\hline $\begin{array}{l}\text { Gr-15 } \\
\text { Gr-15. }\end{array}$ & pg6,pg-grt & 10.894 & 5.054 & 0.009 & 0.009 & 0.003 & 0.010 & 1.121 & 2.877 & 0.035 & 71.300 & 27.800 & 0.900 \\
\hline \multicolumn{14}{|c|}{$\begin{array}{l}\text { Gr-15- } \\
1,3,11,11 A, 12,6\end{array}$} \\
\hline $6 A, 14$ & pg7,pg-grt & 10.916 & 5.061 & 0.004 & 0.000 & 0.004 & 0.003 & 1.104 & 2.859 & 0.044 & 71.400 & 27.600 & 1.100 \\
\hline $\mathrm{Gr}-15$ & pg8,pg-grt & 10.898 & 5.081 & 0.006 & 0.000 & 0.000 & 0.006 & 1.125 & 2.814 & 0.052 & 70.500 & 28.200 & 1.300 \\
\hline
\end{tabular}

Lâmina Z-365-1, gnaisse migmatitico bandeado

Granada

\begin{tabular}{|c|c|c|c|c|c|c|c|c|c|c|c|c|c|c|}
\hline Associação & Análise,Perfil & Loc & SIO2 & AL2O3 & TIO2 & FEO & MNO & $M G O$ & CAO & $\mathrm{NA2O}$ & $\mathrm{CR} 2 \mathrm{O} 3$ & y203 & $B A O$ & TOTAL \\
\hline 36 & $\begin{array}{l}\text { grt1, bt-grt-pg1 } \\
\text { grt2, bt-grt-pg1 }\end{array}$ & $\begin{array}{l}\text { núcleo } \\
\text { interm }\end{array}$ & & $\begin{array}{l}21.457 \\
21.523\end{array}$ & $\begin{array}{l}0.000 \\
0.019\end{array}$ & $\begin{array}{l}31.553 \\
32607\end{array}$ & 0.800 & 6.312 & 0.991 & 0.000 & 0.000 & 0.089 & 0.000 & 160 \\
\hline
\end{tabular}




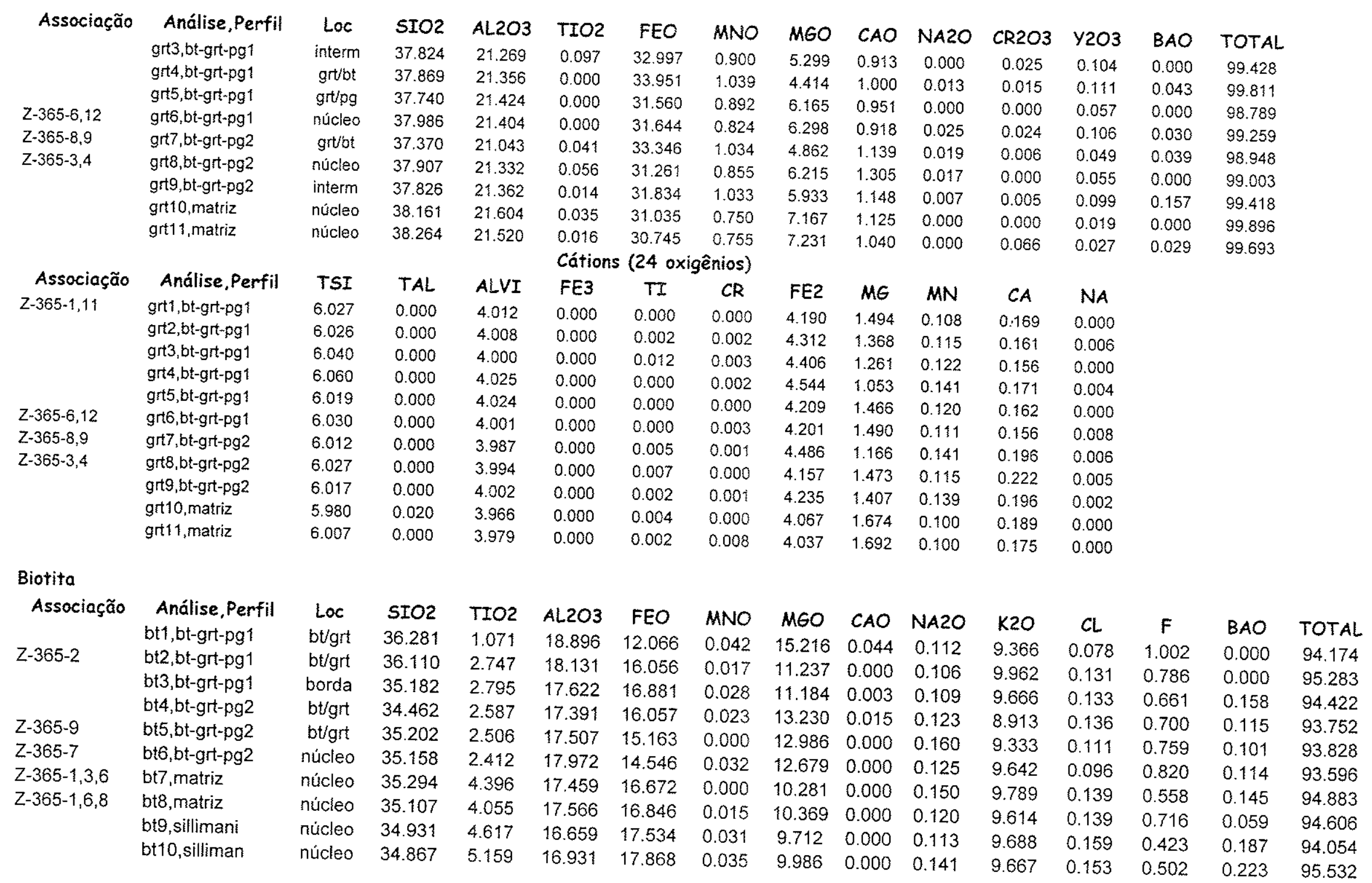




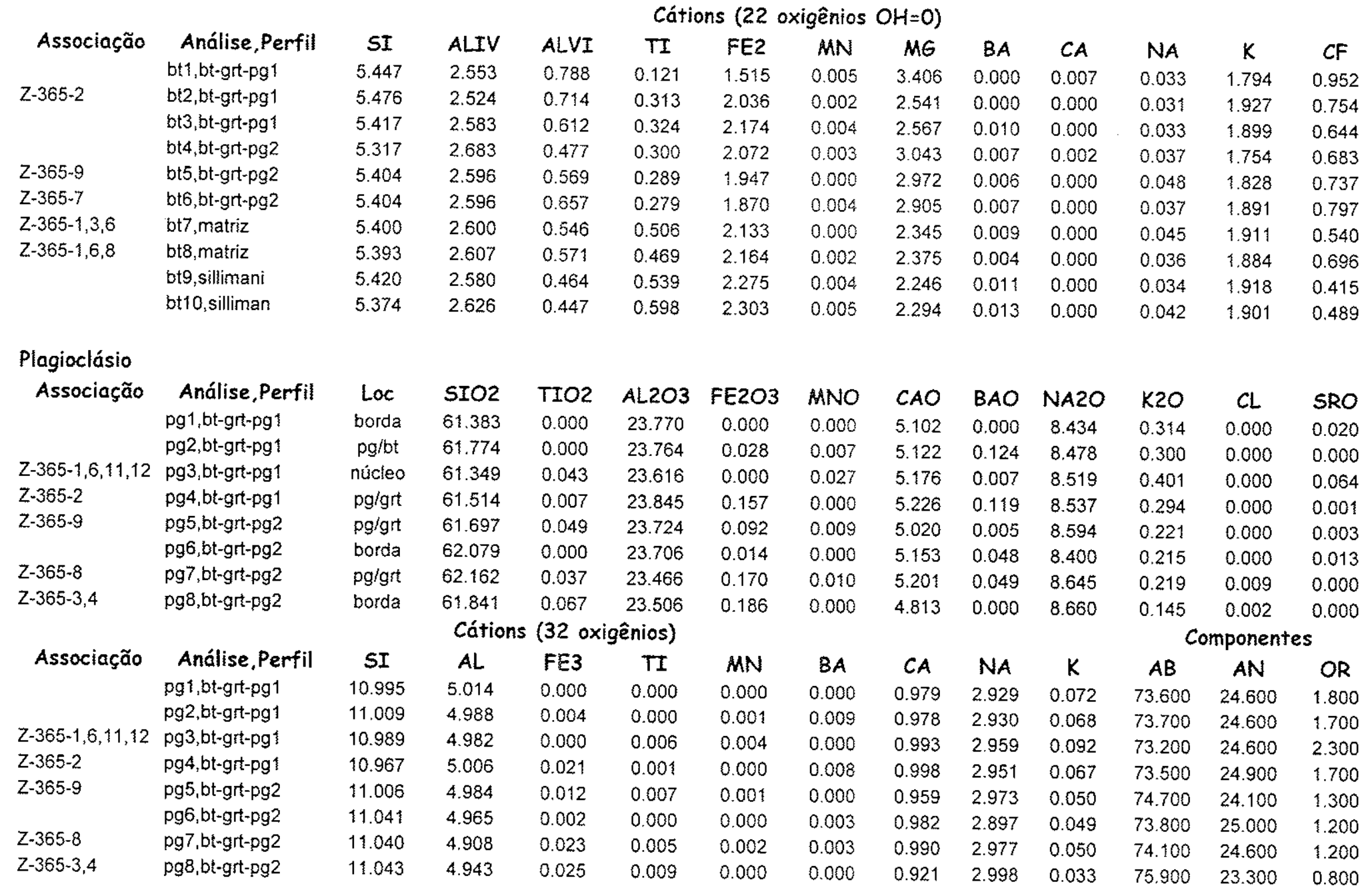


Lâmina Z-365-2, gnaisse migmatitico bandeado

\section{Plagioclasio}

Associação Análise, Perfil

pg1
pg2
microd1

Loc
núcleo
núcleo

Análise Perfil

núcleo

$\begin{array}{llll}61.912 & 23.742 & 0.028 & 0.000\end{array}$

$\begin{array}{llll}64.114 & 18.436 & 0.029 & 0.000\end{array}$

Cátions (32 oxigênios)

Associação

pg2

SI

$\begin{array}{lllll}\mathrm{pg} 2 & 11.013 & 4.973 & 0.004 & 0.000 \\ \text { microcl1 } & 11.919 & 4.036 & 0.004 & 0.000\end{array}$

$0.004 \quad 0.000$

BA

0.000

0.001

$\begin{array}{ccccccc} & B A O & N A 2 O & K 2 O & C L & \text { SRO } & \text { TOTAL } \\ 2 & 0.014 & 8.755 & 0.101 & 0.003 & 0.000 & 99.385 \\ 7 & 0.019 & 8.648 & 0.076 & 0.000 & 0.000 & 99.672 \\ 5 & 0.300 & 1.874 & 14.397 & 0.022 & 0.000 & 99.317\end{array}$

Componentes

$\begin{array}{cccccc}\text { CA } & \text { NA } & K & \text { AB } & \text { AN } & \text { OR } \\ 0.977 & 3.029 & 0.023 & 75.200 & 24.200 & 0.600 \\ 1.000 & 2.983 & 0.017 & 74.600 & 25.000 & 0.400 \\ 0.029 & 0.676 & 3.414 & 16.400 & 0.700 & 82.900\end{array}$

Moscovita

Associação Análise,Perfil moscov1

Loc
núcleo

SIO2

moscov2

núcleo

48.500

$\begin{array}{ccc}\text { TIO2 } & \text { AL2O3 } & \text { FEO } \\ 0.095 & 35.019 & 1.050 \\ 0.022 & 34.828 & 1.116\end{array}$

MNO
0.009

\section{$M G O$}

0.000

8.053

Cl

0.000

0.000

BAO

TOTAL

$0.000 \quad 93.529$

Lâmina $C-32$, granulito

\section{Granada}

Associação Análise,Perfil

$$
\text { grt } 1 \text {, grt-hd-bt1 }
$$

grt2,grt-hd-bt 1

grt 3 ,grt-hd-bt 1

grt 4 , grt-hd-bt1

C-32-102,17A grt5,grt-hd-bt1

grt6, grt-hd-b:1

grt7, grt-hd-bt

grt8, grt-hd-bt1

grt9, grt-hd-bt

grt 10,grt-hd-bt1

grtt1, grk-hd-bt1

grt 12, bt-px-grt 1

grt13,bt-px-grt

grt14, bt-px-grt 1

Loc

STO2

37.700

interm 37.825

núcleo

interm

$37.857 \quad 21.073$

núcieo

interm

interm

37.397

grtpx 37.788

grt/inc,b $\quad 37.672$

interm $\quad 37.719$

grtpx

37.785

$\begin{array}{ll}\text { AL2O3 } & \text { TIO2 } \\ 21.004 & 0.042 \\ 20.992 & 0.000 \\ 21.108 & 0.093 \\ 21.073 & 0.068 \\ 20.904 & 0.184 \\ 20.838 & 0.002 \\ 20.802 & 0.119 \\ 21.116 & 0.000 \\ 20.855 & 0.038 \\ 20.991 & 0.009 \\ 20.716 & 0.026 \\ 20.875 & 0.065 \\ 20.830 & 0.082 \\ 21.051 & 0.070 \\ 20.617 & 0.000\end{array}$

FEO

MNO

MGO

$\begin{array}{ll}28.767 & 2.542 \\ 27.527 & 2.305\end{array}$

$\begin{array}{ll}27.527 & 2.305 \\ 27.979 & 2.350\end{array}$

$28.112 \quad 2.214$

2.868

$\begin{array}{lll}3.386 & 6.570 & 0.015\end{array}$

$\begin{array}{lll}3.793 & 6.590 & 0.012\end{array}$

$\begin{array}{lll}3.816 & 6.483 & 0.024 \\ 3.651 & 6.546 & 0.022\end{array}$

$\begin{array}{llllll}28.040 & 2.381 & 3.651 & 6.546 & 0.022\end{array}$

$\begin{array}{llllll}27.909 & 2.141 & 3.817 & 6.474 & 0.012\end{array}$

$\begin{array}{lllll}27.958 & 2.242 & 3.720 & 6.571 & 0.020\end{array}$

$27.766 \quad 2.430$

$\begin{array}{lll}3.643 & 6.428 & 0.033\end{array}$

$\begin{array}{llllll}27.798 & 2.297 & 3.674 & 6.416 & 0.002\end{array}$

$27.979 \quad 2.382$

$28.530 \quad 2.353$

$\begin{array}{lll}3.540 & 6.549 & 0.011 \\ 3.177 & 6.735 & 0.014\end{array}$

$\begin{array}{lllll}28.206 & 2.252 & 3.106 & 6.611 & 0.035\end{array}$

$\begin{array}{lllll}28.061 & 2.328 & 3.386 & 6.572 & 0.023\end{array}$

$\begin{array}{lllll}28.876 & 2.519 & 2.756 & 7.031 & 0.025\end{array}$

Y203

BAO

TOTAL

100.345

$\begin{array}{llll}0.000 & 0.350 & 0.030 & 98.915\end{array}$

$\begin{array}{llll}0.006 & 0.110 & 0.000 & 99.442\end{array}$

$\begin{array}{llll}0.000 & 0.390 & 0.000 & 100.109\end{array}$

$\begin{array}{llll}0.039 & 0.271 & 0.000 & 99.446\end{array}$

$\begin{array}{llll}0.053 & 0.395 & 0.000 & 99.159\end{array}$

$\begin{array}{llll}0.000 & 0.181 & 0.011 & 98.100\end{array}$

$\begin{array}{llll}0.057 & 0.320 & 0.000 & 99.762\end{array}$

$\begin{array}{llll}0.035 & 0.340 & 0.022 & 99.352\end{array}$

$\begin{array}{llll}0.019 & 0.316 & 0.000 & 98.919\end{array}$

$\begin{array}{lllll}0.074 & 0.386 & 0.051 & 99.232\end{array}$

$\begin{array}{llll}0.014 & 0.348 & 0.077 & 99.974\end{array}$

$\begin{array}{llll}0.070 & 0.312 & 0.044 & 99.220\end{array}$

$\begin{array}{llll}0.017 & 0.381 & 0.000 & 99.608\end{array}$

grt15,bt-px-grt 


\begin{tabular}{|c|c|c|c|c|c|c|c|c|c|c|c|c|c|c|}
\hline Associação & Análise,Perfil & Loc & SIO2 & AL2O3 & TIO2 & FEO & MNO & $M G O$ & $C A O$ & NAZO & $\mathrm{CR} 2 \mathrm{O} 3$ & Y203 & $B A O$ & TOTAL \\
\hline \multirow{9}{*}{ C- $32-3,7$} & grt $16, b t-p x-g r t 1$ & interm & 37.559 & 20.797 & 0.094 & 28.404 & 2.270 & 3.069 & 6.726 & 0.027 & 0.015 & 0.404 & 0.000 & 99.365 \\
\hline & gtt17,bt-px-grt1 & interm & 37.665 & 20.974 & 0.003 & 28.033 & 2.241 & 3.456 & 6.518 & 0.020 & 0.013 & 0.355 & 0.000 & 99.278 \\
\hline & grt18,bt-px-grt1 & grt/px & 37.567 & 20.571 & 0.051 & 28.227 & 2.262 & 3.183 & 6.987 & 0.043 & 0.040 & 0.404 & 0.000 & 99.335 \\
\hline & grt 19, bt-px-grt 1 & interm & 37.536 & 20.855 & 0.072 & 28.473 & 2.265 & 3.169 & 6.594 & 0.049 & 0.010 & 0.368 & 0.000 & 99.391 \\
\hline & gtt20,bt-px-grt & interm & 37.757 & 20.769 & 0.089 & 28.171 & 2.242 & 3.480 & 6.528 & 0.018 & 0.017 & 0.365 & 0.106 & 99.542 \\
\hline & grt21, bt-px-grt1 & grt/px & 37.590 & 20.800 & 0.002 & 28.079 & 2.378 & 3.098 & 6.637 & 0.040 & 0.034 & 0.291 & 0.055 & 99.004 \\
\hline & grt22,bt-px-grt1 & interm & 37.379 & 20.991 & 0.049 & 28.275 & 2.442 & 3.202 & 6.503 & 0.029 & 0.047 & 0.375 & 0.000 & 99.292 \\
\hline & grt23,bt-px-grt2 & $g r t / b t$ & 37.734 & 20.495 & 0.056 & 28.306 & 2.466 & 2.747 & 7.098 & 0.013 & 0.030 & 0.402 & 0.116 & 99.463 \\
\hline & $g t 24, b t-p x-g r t 2$ & interm & 37.751 & 20.778 & 0.003 & 27.995 & 2.303 & 3.415 & 6.703 & 0.030 & 0.068 & 0.333 & 0.022 & 99.401 \\
\hline \multirow[t]{6}{*}{ C-32-8 } & grt25, bt-px-grt2 & núcleo & 37.993 & 21.209 & 0.019 & 28.235 & 2.070 & 3.801 & 6.373 & 0.014 & 0.000 & 0.279 & 0.000 & 99.993 \\
\hline & grt26,bt-px-grt2 & núcleo & 37.785 & 20.986 & 0.024 & 28.194 & 2.179 & 3.758 & 6.609 & 0.010 & 0.049 & 0.233 & 0.031 & 99.858 \\
\hline & gtt27,bt-px-grt2 & interm & 37.945 & 20.762 & 0.000 & 27.631 & 2.204 & 3.725 & 6.455 & 0.010 & 0.009 & 0.224 & 0.000 & 98.965 \\
\hline & grt28,bt-px-grt2 & grt/px & 37.442 & 20.641 & 0.063 & 28.686 & 2.634 & 2.589 & 7.014 & 0.006 & 0.026 & 0.400 & 0.115 & 99.616 \\
\hline & grt29,bt-px-grt2 & grt/px & 37.346 & 20.536 & 0.016 & 28.557 & 2.416 & 2.659 & 7.117 & 0.018 & 0.055 & 0.366 & 0.000 & 99.086 \\
\hline & grt30,bt-px-grt2 & interm & 37.592 & 20.821 & 0.051 & 28.355 & 2.158 & 3.420 & 6.740 & 0.000 & 0.020 & 0.393 & 0.000 & 99.550 \\
\hline \multirow[t]{3}{*}{$C-32+11$} & grt $31, \mathrm{bt}-\mathrm{px}$-grt2 & interm & 37.498 & 20.854 & 0.086 & 27.690 & 2.171 & 3.673 & 6.501 & 0.014 & 0.000 & 0.258 & 0.000 & 98.745 \\
\hline & $\mathrm{grt} 32, \mathrm{bt}-\mathrm{px}-\mathrm{grt} 2$ & núcleo & 37.913 & 20.741 & 0.000 & 27.950 & 2.152 & 3.733 & 6.486 & 0.014 & 0.053 & 0.238 & 0.000 & 99.280 \\
\hline & grt33,bt-px-grt2 & grt/inc, b & 37.679 & 20.777 & 0.064 & 28.898 & 2.223 & 3.321 & 6.611 & 0.051 & 0.022 & 0.326 & 0.000 & 99.972 \\
\hline \multirow[t]{5}{*}{$C-32-16.17$} & $g r t 34, b t-p x-g r t 2$ & git/inc, b & 37.589 & 20.555 & 0.019 & 28.737 & 2.104 & 2.767 & 6.919 & 0.027 & 0.000 & 0.422 & 0.025 & 99.164 \\
\hline & $g+35, b t-p x-g r t 2$ & interm & 37.646 & 20.917 & 0.096 & 28.477 & 2.300 & 3.381 & 6.525 & 0.008 & 0.011 & 0.376 & 0.000 & 99.737 \\
\hline & $g r t 36, b t-p x-g r k 2$ & $g / i n, p x$ & 37.523 & 20.656 & 0.113 & 28.349 & 2.367 & 2.761 & 6.820 & 0.040 & 0.080 & 0.359 & 0.014 & 99.082 \\
\hline & grt37,bt-px-grt2 & g/in,px & 37.468 & 20.645 & 0.078 & 28.533 & 2.367 & 2.912 & 6.515 & 0.007 & 0.065 & 0.429 & 0.000 & 99.019 \\
\hline & grt38,bt-px-grt2 & $g / i n, p x$ & 37.125 & 20.810 & 0.014 & 28.855 & 2.497 & 2.461 & 6.893 & 0.036 & 0.013 & 0.378 & 0.000 & 99.082 \\
\hline C-32-18 & grt39,grt-hd-bt2 & githd & 37.298 & 20.876 & 0.118 & 28.504 & 2.287 & 2.918 & 6.904 & 0.040 & 0.000 & 0.408 & 0.025 & 99.378 \\
\hline \multirow[t]{3}{*}{$C-32-17 \mathrm{~A}$} & grt $40, \mathrm{gtt}-\mathrm{hd}-\mathrm{b} 2$ & núcleo & 37.790 & 20.891 & 0.037 & 28.114 & 2.092 & 3.825 & 6.562 & 0.017 & 0.002 & 0.333 & 0.033 & 99.696 \\
\hline & grt41, gri-hd-bt2 & interm & 38.101 & 20.956 & 0.086 & 27.653 & 2.189 & 3.654 & 6.674 & 0.006 & 0.010 & 0.374 & 0.000 & 99.703 \\
\hline & \multicolumn{14}{|c|}{ Cátions (24 oxigênios) } \\
\hline Associação & Análise,Perfil & TSI & TAL & ALVI & TI & $C R$ & FE2 & $M G$ & $M N$ & $C A$ & NA & & & \\
\hline \multirow[t]{4}{*}{ C-32-14,15 } & grt1,grt-hd-bt1 & 5.984 & 0.016 & 3.910 & 0.005 & 0.009 & 3.818 & 0.679 & 0.342 & 1.238 & 0.000 & & & \\
\hline & grt2,grt-hd-bt1 & 6.055 & 0.000 & 3.970 & 0.000 & 0.000 & 3.697 & 0.850 & 0.314 & 1.109 & 0.005 & & & \\
\hline & gt 3 ,grt-hd-bt1 & 6.036 & 0.000 & 3.967 & 0.011 & 0.001 & 3.734 & 0.806 & 0.318 & 1.123 & 0.005 & & & \\
\hline & grt4,gtt-hd-bti & 6.006 & 0.000 & 3.937 & 0.008 & 0.000 & 3.730 & 0.897 & 0.298 & 1.120 & 0.004 & & & \\
\hline \multirow[t]{5}{*}{$C-32-102,17 \mathrm{~A}$} & grt5,grt-hd-bt1 & 5.996 & 0.004 & 3.924 & 0.022 & 0.005 & 3.717 & 0.908 & 0.308 & 1.108 & 0.007 & & & \\
\hline & gtt,$g r t-h d-b t 1$ & 5.970 & 0.030 & 3.905 & 0.000 & 0.007 & 3.760 & 0.873 & 0.323 & 1.125 & 0.007 & & & \\
\hline & grt7,grt-hd-bt 1 & 5.919 & 0.081 & 3.877 & 0.014 & 0.000 & 3.771 & 0.919 & 0.293 & 1.121 & 0.004 & & & \\
\hline & grt8,grt-hd-bt1 & 6.007 & 0.000 & 3.856 & 0.000 & 0.007 & 3.720 & 0.882 & 0.302 & 1.120 & 0.006 & & & \\
\hline & grt9,grt-hd-bt1 & 6.040 & 0.000 & 3.928 & 0.005 & 0.004 & 3.714 & 0.869 & 0.329 & 1.102 & 0.010 & & & \\
\hline
\end{tabular}




\begin{tabular}{|c|c|c|c|c|c|c|c|c|c|c|c|}
\hline \multirow[t]{6}{*}{ Associação } & Análise,Perfil & TSI & TAL & ALVI & TI & $C R$ & FE2 & $M G$ & $M N$ & $C A$ & NA \\
\hline & gtt10,gtt-hd-bt1 & 6.002 & 0.000 & 3.968 & 0.001 & 0.002 & 3.731 & 0.879 & 0.312 & 1.103 & 0.001 \\
\hline & grt11,grt-hd-bt1 & 6.019 & 0.000 & 3.914 & 0.003 & 0.009 & 3.754 & 0.847 & 0.324 & 1.126 & 0.003 \\
\hline & $\mathrm{grt} 12, \mathrm{bt}-\mathrm{px}$-grt1 & 6.030 & 0.000 & 3.923 & 0.008 & 0.002 & 3.808 & 0.756 & 0.318 & 1.152 & 0.004 \\
\hline & $g r t 13, b t-p x-g r t 1$ & 6.052 & 0.000 & 3.941 & 0.010 & 0.009 & 3.789 & 0.744 & 0.306 & 1.138 & 0.011 \\
\hline & grt14,bt-px-grt1 & 6.026 & 0.000 & 3.961 & 0.008 & 0.002 & 3.749 & 0.806 & 0.315 & 1.125 & 0.007 \\
\hline \multirow[t]{2}{*}{$C-32-4$} & $g r t 15, b t-p \times-g r t 1$ & 6.043 & 0.000 & 3.883 & 0.000 & 0.001 & 3.862 & 0.657 & 0.341 & 1.205 & 0.008 \\
\hline & $g r t 16, b t-p x-g r t 1$ & 6.031 & 0.000 & 3.933 & 0.011 & 0.002 & 3.814 & 0.735 & 0.309 & 1.157 & 0.008 \\
\hline \multirow[t]{8}{*}{ C- $-32-3,7$} & grt17,bt-px-grt1 & 6.033 & 0.000 & 3.956 & 0.000 & 0.002 & 3.755 & 0.825 & 0.304 & 1.119 & 0.006 \\
\hline & grt18,bt-px-grt1 & 6.029 & 0.000 & 3.888 & 0.006 & 0.005 & 3.788 & 0.762 & 0.307 & 1.201 & 0.013 \\
\hline & grt19,bt-px-grt & 6.019 & 0.000 & 3.939 & 0.009 & 0.001 & 3.819 & 0.758 & 0.308 & 1.133 & 0.015 \\
\hline & grt20,bt-px-grt 1 & 6.043 & 0.000 & 3.915 & 0.011 & 0.002 & 3.771 & 0.830 & 0.304 & 1.119 & 0.006 \\
\hline & grt21,bt-px-grt1 & 6.050 & 0.000 & 3.942 & 0.000 & 0.004 & 3.779 & 0.743 & 0.324 & 1.144 & 0.012 \\
\hline & grt22, bt-px-gtt & 6.000 & 0.000 & 3.967 & 0.006 & 0.006 & 3.795 & 0.766 & 0.332 & 1.118 & 0.009 \\
\hline & grt23, bt-px-grt2 & 6.073 & 0.000 & 3.884 & 0.007 & 0.004 & 3.810 & 0.659 & 0.336 & 1.224 & 0.004 \\
\hline & grt 24, bt-px-grt2 & 6.042 & 0.000 & 3.916 & 0.000 & 0.009 & 3.747 & 0.815 & 0.312 & 1.149 & 0.009 \\
\hline \multirow[t]{6}{*}{$C-32-8$} & grt25,bt-px-grt2 & 6.026 & 0.000 & 3.962 & 0.002 & 0.000 & 3.745 & 0.899 & 0.278 & 1.083 & 0.004 \\
\hline & $\mathrm{grt} 26, \mathrm{bt}-\mathrm{px}-\mathrm{grt} 2$ & 6.005 & 0.000 & 3.927 & 0.003 & 0.006 & 3.747 & 0.890 & 0.293 & 1.125 & 0.003 \\
\hline & grt27,bt-px-grt2 & 6.079 & 0.000 & 3.917 & 0.000 & 0.001 & 3.702 & 0.890 & 0.299 & 1.108 & 0.003 \\
\hline & $g r 28, b t-p x-g r t 2$ & 6.025 & 0.000 & 3.912 & 0.008 & 0.003 & 3.861 & 0.621 & 0.359 & 1.209 & 0.002 \\
\hline & grt29,bt-px-grt2 & 6.027 & 0.000 & 3.903 & 0.002 & 0.007 & 3.854 & 0.640 & 0.330 & 1.231 & 0.006 \\
\hline & $g r t 30, b \xi-p x-g r t 2$ & 6.013 & 0.000 & 3.922 & 0.006 & 0.003 & 3.793 & 0.816 & 0.292 & 1.155 & 0.000 \\
\hline \multirow[t]{3}{*}{$C-32-11$} & grt31, bt-px-grt2 & 6.025 & 0.000 & 3.946 & 0.010 & 0.000 & 3.721 & 0.880 & 0.295 & 1.119 & 0.004 \\
\hline & $\mathrm{grt} 32, \mathrm{bt}-\mathrm{px}-\mathrm{grt} 2$ & 6.059 & 0.000 & 3.903 & 0.000 & 0.007 & 3.735 & 0.889 & 0.291 & 1.111 & 0.004 \\
\hline & gtt33,bt-px-grt2 & 6.005 & 0.000 & 3.899 & 0.008 & 0.003 & 3.852 & 0.789 & 0.300 & 1.129 & 0.016 \\
\hline \multirow[t]{5}{*}{$C-32-16,17$} & grt 34, bt-px-grt2 & 6.062 & 0.000 & 3.904 & 0.002 & 0.000 & 3.876 & 0.665 & 0.287 & 1.195 & 0.008 \\
\hline & $g r t 35, b t-p x-g r t 2$ & 6.013 & 0.000 & 3.935 & 0.012 & 0.001 & 3.804 & 0.805 & 0.311 & 1.117 & 0.002 \\
\hline & grt36,bt-px-grt2 & 6.051 & 0.000 & 3.923 & 0.014 & 0.010 & 3.823 & 0.664 & 0.323 & 1.178 & 0.013 \\
\hline & grt37,bt-px-grt2 & 6.050 & 0.000 & 3.926 & 0.009 & 0.008 & 3.853 & 0.701 & 0.324 & 1.127 & 0.002 \\
\hline & $g r t 38, b t-p x-g r 2$ & 5.999 & 0.001 & 3.958 & 0.002 & 0.002 & 3.899 & 0.593 & 0.342 & 1.193 & 0.011 \\
\hline$C-32-18$ & grt39, grt-hd-bt2 & 0.000 & 99.380 & 0.007 & 3.944 & 0.000 & 0.000 & 3.958 & 3.830 & 0.699 & 0.311 \\
\hline \multirow[t]{2}{*}{ C-32-17A } & grt40,grt-hd-bt2 & 0.000 & 99.700 & 0.000 & 3.918 & 0.000 & 0.000 & 3.923 & 3.744 & 0.908 & 0.282 \\
\hline & grt $41, g r t-h d-b t 2$ & 0.000 & 99.700 & 0.000 & 3.931 & 0.000 & 0.001 & 3.943 & 3.684 & 0.868 & 0.295 \\
\hline
\end{tabular}


Biotita

\begin{tabular}{|c|c|c|c|c|c|c|c|c|c|c|c|c|c|c|c|}
\hline Associação & Análise Perfil & Loc & SIO2 & TIO2 & AL2O3 & FEO & MNO & $M G O$ & $C A O$ & $\mathrm{NAZO}$ & $\mathrm{k} 20$ & $C L$ & $F$ & $B A O$ & TOTAL \\
\hline & bt1,grt-hd-bt1 & btgrt & 35.858 & 5.656 & 14.028 & 21.464 & 0.063 & 9.441 & 0.005 & 0.027 & 9.450 & 0.152 & 0.395 & 0.280 & 96.819 \\
\hline C. $32-14$ & bt2,grt-hd-btt & núcleo & 35.437 & 5.563 & 14.038 & 21.397 & 0.104 & 9.299 & 0.000 & 0.032 & 9.572 & 0.164 & 0.693 & 0.363 & 96.662 \\
\hline \multirow[t]{8}{*}{ C-32-15 } & bt3,grt-hd-bt1 & núcleo & 35.623 & 4.985 & 13.892 & 21.658 & 0.091 & 9.402 & 0.000 & 0.031 & 9.432 & 0.161 & 0.129 & 0.305 & 95.709 \\
\hline & bł4,gtt-hd-bt1 & borda & 35.752 & 5.692 & 14.068 & 21.562 & 0.102 & 9.334 & 0.000 & 0.039 & 9.441 & 0.160 & 0.490 & 0.339 & 96.979 \\
\hline & bt5,grt-hd-bt1 & núcleo & 35.171 & 5.172 & 14.126 & 22.233 & 0.104 & 9.164 & 0.000 & 0.038 & 9.178 & 0.137 & 0.353 & 0.438 & 96.114 \\
\hline & $b t 1 \sin , g r t-h d-b t 1$ & borda & 35.706 & 4.756 & 13.817 & 21.790 & 0.028 & 9.195 & 0.000 & 0.046 & 9.388 & 0.160 & 0.556 & 0.251 & 95.693 \\
\hline & $b t 2 \sin , g r t-h d-b t 1$ & núcleo & 35.711 & 5.040 & 13.982 & 22.064 & 0.050 & 9.379 & 0.031 & 0.026 & 9.271 & 0.143 & 0.248 & 0.310 & 96.255 \\
\hline & bt3sin,grt-hd-bt1 & borda & 35.450 & 5.102 & 13.822 & 21.136 & 0.056 & 9.071 & 0.020 & 0.035 & 9.398 & 0.149 & 0.364 & 0.389 & 94.992 \\
\hline & bt6,bt-pxngt1 & bt/px & 35.257 & 5.103 & 14.016 & 21.759 & 0.025 & 9.622 & 0.015 & 0.016 & 9.490 & 0.171 & 0.386 & 0.321 & 96.181 \\
\hline & bt7,bt-px-grt1 & núcleo & 35.401 & 4.997 & 14.220 & 21.677 & 0.058 & 9.602 & 0.013 & 0.060 & 9.306 & 0.143 & 0.250 & 0.366 & 96.093 \\
\hline$C-32-5$ & bt8, bt-px-grtt & núcleo & 35.477 & 5.073 & 14.229 & 21.691 & 0.099 & 9.604 & 0.024 & 0.031 & 9.361 & 0.180 & 0.436 & 0.152 & 96.357 \\
\hline C-32-7 & bt8inc, bt-px-grt 1 & in-grt & 35.284 & 5.813 & 14.006 & 19.698 & 0.065 & 10.499 & 0.121 & 0.081 & 8.973 & 0.140 & 0.422 & 0.268 & 95.370 \\
\hline \multirow[t]{2}{*}{$C \cdot 32+1,2,3,8.11,17,17 \mathrm{~A}$} & bt9inc, bt-px-grt1 & in-grt & 35.031 & 5.856 & 14.260 & 19.546 & 0.045 & 10.502 & 0.105 & 0.081 & 8.926 & 0.131 & 0.309 & 0.348 & 95.140 \\
\hline & bt $10, b t-p x-g r t 1$ & $\mathrm{~b} t / \mathrm{px}$ & 35.908 & 4.743 & 14.208 & 21.177 & 0.050 & 10.277 & 0.012 & 0.053 & 9.480 & 0.147 & 0.566 & 0.133 & 96.754 \\
\hline \multirow[t]{2}{*}{$C-32-4$} & bt11,bt-px-grt1 & núcleo & 35.916 & 4.899 & 14.157 & 21.334 & 0.025 & 10.120 & 0.048 & 0.023 & 9.493 & 0.176 & 0.580 & 0.230 & 97.001 \\
\hline & bt12,bt-px-grt1 & borda & 35.729 & 5.222 & 14.239 & 21.441 & 0.136 & 9.617 & 0.016 & 0.028 & 9.329 & 0.174 & 0.386 & 0.430 & 96.747 \\
\hline \multirow[t]{14}{*}{ C. $32-16,17$} & bt13inc,bt-px-grt2 & incl-grt & 35.127 & 5.120 & 13.730 & 22.131 & 0.045 & 9.881 & 0.050 & 0.058 & 8.994 & 0.165 & 0.410 & 0.232 & 95.943 \\
\hline & bt14inc,bt-px-grt2 & incl-grt & 35.465 & 4.731 & 13.723 & 21.776 & 0.012 & 9.827 & 0.039 & 0.035 & 9.126 & 0.150 & 0.350 & 0.307 & 95.541 \\
\hline & bt15inc,bt-px-grt2 & incl-grt & 35.307 & 4.729 & 13.751 & 21.560 & 0.048 & 9.691 & 0.019 & 0.056 & 9.263 & 0.147 & 0.345 & 0.373 & 95.289 \\
\hline & bt16,bt-px-grt2 & bt/grt & 35.038 & 5.088 & 13.884 & 21.715 & 0.109 & 9.470 & 0.061 & 0.039 & 9.085 & 0.165 & 0.485 & 0.180 & 95.319 \\
\hline & bt17,bt-px-grt2 & btgrt & 35.490 & 5.446 & 14.007 & 21.763 & 0.025 & 9.378 & 0.069 & 0.022 & 9.085 & 0.174 & 0.179 & 0.297 & 95.935 \\
\hline & $b t 18, b t-p x-g r t 2$ & núcleo & 35.291 & 5.364 & 13.947 & 22.299 & 0.071 & 9.289 & 0.043 & 0.026 & 9.104 & 0.186 & 0.486 & 0.277 & 96.383 \\
\hline & $b t 19, b t-p x-g r t 2$ & กúcleo & 35.299 & 5.193 & 13.996 & 22.018 & 0.069 & 9.365 & 0.041 & 0.040 & 9.009 & 0.167 & 0.502 & 0.309 & 96.008 \\
\hline & $b t 20, b t-p x-g r t 2$ & borda & 34.931 & 4.962 & 13.911 & 22.417 & 0.061 & 9.238 & 0.059 & 0.063 & 9.059 & 0.178 & 0.375 & 0.376 & 95.630 \\
\hline & $b t 4, \sin$ & borda & 35.467 & 5.014 & 14.180 & 21.786 & 0.028 & 9.376 & 0.023 & 0.024 & 9.517 & 0.189 & 0.25 & 0.346 & 96.201 \\
\hline & $b \pm 5, \sin$ & núcleo & 35.685 & 4.940 & 14.093 & 21.703 & 0.061 & 9.406 & 0.010 & 0.023 & 9.336 & 0.165 & 0.381 & 0.297 & 96.100 \\
\hline & bt6, $\sin$ & barda & 35.713 & 4.592 & 14.061 & 21.738 & 0.126 & 9.498 & 0.023 & 0.032 & 9.136 & 0.175 & 0.436 & 0.310 & 95.840 \\
\hline & bt21, matriz & borda & 35.441 & 4.853 & 13.962 & 22.739 & 0.089 & 8.988 & 0.026 & 0.049 & 9.170 & 0.165 & 0.462 & 0.170 & 96.114 \\
\hline & bt22, matriz & borda & 35.423 & 4.914 & 14.221 & 22.264 & 0.112 & 9.009 & 0.019 & 0.012 & 9.428 & 0.161 & 0.316 & 0.448 & 96.327 \\
\hline & $b+23, g r t-h d-b t 2$ & bt/hd & 35.718 & 5.277 & 14.012 & 21.460 & 0.088 & 9.485 & 0.032 & 0.008 & 9.320 & 0.153 & 0.257 & 0.340 & 96.150 \\
\hline \multirow[t]{2}{*}{$C-32-18$} & bt24,grt-hd-bt2 & núcleo & 35.781 & 5.040 & 14.075 & 21.170 & 0.037 & 9.326 & 0.034 & 0.031 & 9.349 & 0.149 & 0.278 & 0.223 & 95.493 \\
\hline & bt25,grt-hd-bt2 & borda & 35.444 & 4.493 & 13.941 & 21.520 & 0.018 & 9.347 & 0.041 & 0.030 & 9.327 & 0.178 & 0.479 & 0.146 & 94.964 \\
\hline
\end{tabular}




\begin{tabular}{|c|c|c|c|c|c|c|c|c|c|c|c|c|c|c|}
\hline \multirow{3}{*}{ Associação } & \multicolumn{14}{|c|}{ Cátions (22 oxigênios, $\mathrm{OH}=0$ ) } \\
\hline & Análise, Perfil & SI & AlLIV & ALVI & $\pi$ & FE2 & $M N$ & $M G$ & $B A$ & $C A$ & NA & K & CF & $C C L$ \\
\hline & bt1,gtt-hd-bt1 & 5.506 & 2.494 & 0.043 & 0.653 & 2.756 & 0.008 & 2.161 & 0.017 & 0.001 & 0.008 & 1.851 & 0.384 & 0.079 \\
\hline$C-32-14$ & $b t 2, g r t-h d-b t 1$ & 5.483 & 2.517 & 0.041 & 0.647 & 2.769 & 0.014 & 2.145 & 0.022 & 0.000 & 0.010 & 1.889 & 0.678 & 0.086 \\
\hline \multirow[t]{8}{*}{$C-32-15$} & bt 3, grt-hd-bt1 & 5.531 & 2.469 & 0.071 & 0.582 & 2.812 & 0.012 & 2.176 & 0.019 & 0.000 & 0.009 & 1.868 & 0.127 & 0.085 \\
\hline & bt 4, grt-hd-bit 1 & 5.494 & 2.506 & 0.040 & 0.658 & 2.771 & 0.013 & 2.138 & 0.020 & 0.000 & 0.012 & 1.851 & 0.476 & 0.083 \\
\hline & bt5,gtt-hd-bt1 & 5.468 & 2.532 & 0.054 & 0.605 & 2.891 & 0.014 & 2.124 & 0.027 & 0.000 & 0.011 & 1.820 & 0.347 & 0.072 \\
\hline & bt1sin,grt-hd-bt1 & 5.568 & 2.432 & 0.105 & 0.558 & 2.842 & 0.004 & 2.137 & 0.015 & 0.000 & 0.014 & 1.868 & 0.548 & 0.085 \\
\hline & bt2sin,grt-hd-bt1 & 5.521 & 2.479 & 0.067 & 0.586 & 2.853 & 0.007 & 2.162 & 0.019 & 0.005 & 0.008 & 1.829 & 0.243 & 0.075 \\
\hline & $b t 3 \sin , g r t-h d-b t\}$ & 5.552 & 2.448 & 0.101 & 0.601 & 2.768 & 0.007 & 2.118 & 0.024 & 0.003 & 0.011 & 1.878 & 0.361 & 0.079 \\
\hline & $b t 6, b t-p x-g r t 1$ & 5.472 & 2.528 & 0.034 & 0.596 & 2.824 & 0.003 & 2.226 & 0.020 & 0.002 & 0.005 & 1.879 & 0.379 & 0.090 \\
\hline & bt7,bt-px-grti & 5.481 & 2.519 & 0.074 & 0.582 & 2.807 & 0.008 & 2.216 & 0.022 & 0.002 & 0.018 & 1.838 & 0.245 & 0.075 \\
\hline$C-32-5$ & bt8,bt-px-grt1 & 5.482 & 2.518 & 0.071 & 0.590 & 2.803 & 0.013 & 2.212 & 0.009 & 0.004 & 0.009 & 1.845 & 0.426 & 0.094 \\
\hline$C-32-7$ & $b t 8$ inc, bt-px-grt 1 & 5.455 & 2.545 & 0.005 & 0.676 & 2.547 & 0.009 & 2.420 & 0.016 & 0.020 & 0.024 & 1.770 & 0.413 & 0.073 \\
\hline \multirow[t]{2}{*}{$C-32-1,2,3,8,11,17,17 \mathrm{~A}$} & bt9inc,bt-px-grt1 & 5.422 & 2.578 & 0.021 & 0.682 & 2.530 & 0.006 & 2.423 & 0.021 & 0.017 & 0.024 & 1.762 & 0.302 & 0.069 \\
\hline & bt10,bt-px-grt1 & 5.512 & 2.488 & 0.081 & 0.548 & 2.719 & 0.007 & 2.352 & 0.008 & 0.002 & 0.016 & 1.857 & 0.550 & 0.077 \\
\hline \multirow[t]{2}{*}{$C-32-4$} & bt11,bt-px-grt1 & 5.510 & 2.490 & 0.068 & 0.565 & 2.737 & 0.003 & 2.314 & 0.014 & 0.008 & 0.007 & 1.858 & 0.563 & 0.092 \\
\hline & bt12,bt-px-grt1 & 5.495 & 2.505 & 0.074 & 0.604 & 2.758 & 0.018 & 2.205 & 0.026 & 0.003 & 0.008 & 1.830 & 0.375 & 0.091 \\
\hline \multirow[t]{14}{*}{$C-32-16,17$} & bt13inc,bt-px-grt2 & 5.463 & 2.515 & 0.000 & 0.599 & 2.879 & 0.006 & 2.291 & 0.014 & 0.008 & 0.017 & 1.785 & 0.403 & 0.087 \\
\hline & bt14inc,bt-px-grt2 & 5.526 & 2.474 & 0.044 & 0.554 & 2.837 & 0.002 & 2.283 & 0.019 & 0.007 & 0.011 & 1.814 & 0.345 & 0.079 \\
\hline & bt15inc,bt-px-grt2 & 5.521 & 2.479 & 0.053 & 0.556 & 2.819 & 0.006 & 2.259 & 0.023 & 0.003 & 0.017 & 1.848 & 0.341 & 0.078 \\
\hline & bt16,bt-px-grt2 & 5.482 & 2.518 & 0.040 & 0.599 & 2.841 & 0.014 & 2.209 & 0.011 & 0.010 & 0.012 & 1.813 & 0.480 & 0.088 \\
\hline & bt17,bt-px-grt2 & 5.493 & 2.507 & 0.046 & 0.634 & 2.817 & 0.003 & 2.164 & 0.018 & 0.011 & 0.007 & 1.794 & 0.175 & 0.091 \\
\hline & bt18,bt-px-grt2 & 5.473 & 2.527 & 0.020 & 0.626 & 2.892 & 0.009 & 2.148 & 0.017 & 0.007 & 0.008 & 1.801 & 0.477 & 0.098 \\
\hline & bt19,bt-px-grt2 & 5.487 & 2.513 & 0.049 & 0.607 & 2.862 & 0.009 & 2.170 & 0.019 & 0.007 & 0.012 & 1.786 & 0.493 & 0.088 \\
\hline & bt20,bt-px-grt2 & 5.468 & 2.532 & 0.032 & 0.584 & 2.935 & 0.008 & 2.156 & 0.023 & 0.010 & 0.019 & 1.809 & 0.371 & 0.094 \\
\hline & $b \pm 4, \sin$ & 5.494 & 2.506 & 0.081 & 0.584 & 2.822 & 0.004 & 2.165 & 0.021 & 0.004 & 0.007 & 1.881 & 0.246 & 0.099 \\
\hline & $b t 5, \sin$ & 5.527 & 2.473 & 0.097 & 0.575 & 2.811 & 0.008 & 2.172 & 0.018 & 0.002 & 0.007 & 1.845 & 0.373 & 0.087 \\
\hline & $b t 6, \sin$ & 5.547 & 2.453 & 0.119 & 0.536 & 2.824 & 0.017 & 2.199 & 0.019 & 0.004 & 0.010 & 1.810 & 0.428 & 0.092 \\
\hline & bt21, matriz & 5.516 & 2.484 & 0.075 & 0.568 & 2.960 & 0.012 & 2.085 & 0.010 & 0.004 & 0.015 & 1.821 & 0.455 & 0.087 \\
\hline & bt22, matriz & 5.498 & 2.502 & 0.097 & 0.574 & 2.890 & 0.015 & 2.084 & 0.027 & 0.003 & 0.004 & 1.867 & 0.310 & 0.085 \\
\hline & bt23,grt-hd-bt2 & 5.517 & 2.483 & 0.066 & 0.613 & 2.772 & 0.012 & 2.184 & 0.021 & 0.005 & 0.002 & 1.837 & 0.251 & 0.080 \\
\hline \multirow[t]{2}{*}{$C-32-18$} & $b t 24$, grt-hd-bt2 & 5.552 & 2.448 & 0.124 & 0.588 & 2.747 & 0.005 & 2.157 & 0.014 & 0.006 & 0.009 & 1.851 & 0.273 & 0.078 \\
\hline & bt25,grt-hd-bt2 & 5.557 & 2.443 & 0.131 & 0.530 & 2.822 & 0.002 & 2.185 & 0.009 & 0.007 & 0.009 & 1.865 & 0.475 & 0.095 \\
\hline
\end{tabular}




\section{Piroxênio}

\begin{tabular}{|c|c|c|c|c|c|c|c|c|c|c|c|c|c|}
\hline \multirow[t]{4}{*}{ Associação } & Análise,Perfil & Loc & SIO2 & TIO2 & AL2O3 & FEO & MNO & $M G O$ & $C A O$ & $\mathrm{NA2O}$ & $\mathrm{K} 2 \mathrm{O}$ & CR2O3 & TOTAL \\
\hline & $p \times 1, b t-p \times-g r t 1$ & $\mathrm{px} / \mathrm{gr}$ & 50.570 & 0.030 & 0.848 & 32.064 & 0.834 & 14.749 & 1.103 & 0.020 & 0.002 & 0.000 & 100.220 \\
\hline & $p \times 2$,bt-px-gtt & $\mathrm{px} / \mathrm{gr}$ & 50.061 & 0.085 & 0.984 & 33.149 & 0.889 & 14.280 & 0.827 & 0.010 & 0.000 & 0.000 & 100.285 \\
\hline & $p \times 3, b t-p \times-g+t$ & interm & 50.377 & 0.157 & 1.042 & 32.638 & 0.876 & $\$ 4.122$ & 1.076 & 0.014 & 0.000 & 0.031 & 100.333 \\
\hline$-32 \cdot 3,7$ & $\mathrm{p} \times 4, \mathrm{bt}-\mathrm{p} \times-\mathrm{grt}$ & núcleo & 50.546 & 0.050 & 0.807 & 33.085 & 0.818 & 14.303 & 0.762 & 0.015 & 0.002 & 0.039 & 100.427 \\
\hline \multirow[t]{10}{*}{ C-32-4 } & $p \times 5, b t-p \times-g r t 1$ & borda & 50.137 & 0.167 & 1.060 & 33.135 & 0.853 & 14.123 & 0.920 & 0.036 & 0.006 & 0.006 & 100.443 \\
\hline & $p \times 6, b t-p x-g r t 1$ & $p \times / g r t$ & 49.918 & 0.002 & 0.950 & 33.149 & 0.910 & 14.268 & 0.502 & 0.004 & 0.000 & 0.000 & 99.701 \\
\hline & $p \times 7, b t-p x-g r t 1$ & $p \times / g r t$ & 50.333 & 0.065 & 0.983 & 32.194 & 0.887 & $\$ 4.489$ & 0.768 & 0.013 & 0.003 & 0.014 & 99.749 \\
\hline & $p \times 8, b t-p x-g r t 1$ & núcleo & 50.146 & 0.111 & 0.925 & 32.614 & 0.818 & 14.258 & 0.957 & 0.020 & 0.020 & 0.000 & 99.869 \\
\hline & $p \times 9, b t-p \times-g i t 1$ & núcleo & 49.948 & 0.080 & 1.202 & 32.936 & 0.917 & 14.318 & 0.750 & 0.013 & 0.000 & 0.015 & 100.179 \\
\hline & $p \times 10, b t-p x-g r t 1$ & $\mathrm{px} / \mathrm{bt}$ & 49.975 & 0.035 & 1.098 & 32.660 & 0.926 & 14.348 & 0.900 & 0.037 & 0.004 & 0.000 & 99.983 \\
\hline & $p \times 1\}, b t-p x-g r t 2$ & $\mathrm{px} / \mathrm{br}$ & 50.310 & 0.066 & 1.007 & 32.584 & 0.941 & 14.292 & 0.823 & 0.041 & 0.000 & 0.004 & 100.068 \\
\hline & $\mathrm{p} \times 12, \mathrm{bt}-\mathrm{px}-\mathrm{grt} 2$ & interm & 50.358 & 0.078 & 1.021 & 32.882 & 0.906 & 14.131 & 0.910 & 0.024 & 0.000 & 0.000 & 100.310 \\
\hline & $p \times 13, b t-p x-g r t 2$ & núcleo & 49.805 & $0 .\{11$ & 1.216 & 32.773 & 0.919 & 14.052 & 0.891 & 0.044 & 0.014 & 0.002 & 99.827 \\
\hline & $p \times 14$, bt-px-grt2 & núcleo & 49.891 & 0.097 & 1.061 & 32.952 & 0.945 & 14.243 & 0.894 & 0.033 & 0.000 & 0.000 & 100.116 \\
\hline \multirow[t]{11}{*}{ C-32-8, 11} & $p \times 15, b t-p x-g r t 2$ & interm & 50.005 & 0.000 & 1.133 & 32.412 & 0.991 & 14.069 & 0.899 & 0.022 & 0.000 & 0.025 & 99.556 \\
\hline & $p \times 16, b t-p x-g r t 2$ & borda & 49.929 & 0.099 & 1.092 & 32.842 & 0.893 & 14.187 & 0.777 & 0.001 & 0.000 & 0.000 & 99.820 \\
\hline & $p \times 17, b t-p x-g r t 2$ & $\mathrm{px} / \mathrm{bt}$ & 49.511 & 0.114 & 1.120 & 32.831 & 0.844 & 14.079 & 0.909 & 0.039 & 0.000 & 0.000 & 99.447 \\
\hline & $p \times 18, b t-p x-g r t 2$ & interm & 49.813 & 0.104 & 1.061 & 32.518 & 0.910 & 13.980 & 0.921 & 0.025 & 0.000 & 0.005 & 99.337 \\
\hline & $p \times 19, b t-p x-g r t 2$ & núcleo & 49.819 & 0.165 & 1.216 & 32.502 & 0.857 & 14.080 & 0.954 & 0.026 & 0.014 & 0.000 & 99.633 \\
\hline & $p \times 20, b t-p x-g r t 2$ & núcleo & 49.960 & 0.137 & 1.176 & 32.614 & 0.925 & 14.001 & 1.135 & 0.011 & 0.020 & 0.044 & 100.023 \\
\hline & $\mathrm{p} \times 21, \mathrm{bt}-\mathrm{px}-\mathrm{grt} 2$ & กúcleo & 50.045 & 0.120 & 1.151 & 32.563 & 1.020 & 13.947 & 1.011 & 0.010 & 0.001 & 0.000 & 99.868 \\
\hline & $p \times 22$, bt-px-grt 2 & núcleo & 49.876 & 0.040 & 1.046 & 32.421 & 0.893 & 14.371 & 0.856 & 0.000 & 0.028 & 0.008 & 99.539 \\
\hline & $p \times 23, b t-p x-g r t 2$ & núcleo & 50.035 & 0.085 & 1.201 & 32.332 & 1.019 & 14.238 & 1.009 & 0.033 & 0.017 & 0.070 & 100.039 \\
\hline & $p \times 24, b t-p x-g r t 2$ & núcleo & 49.781 & 0.206 & 0.810 & 32.881 & 0.982 & 14.192 & 0.900 & 0.013 & 0.000 & 0.000 & 99.765 \\
\hline & $\mathrm{p} \times 25, \mathrm{bt}-\mathrm{p} \times \mathrm{-grt} 2$ & interm & 49.773 & 0.056 & 1.088 & 32.690 & 0.933 & 13.982 & 0.892 & 0.016 & 0.008 & 0.063 & 99.501 \\
\hline$C-32-16,17$ & $\mathrm{p} \times 26, \mathrm{bt}-\mathrm{p} \times-\mathrm{gt} 2$ & borda & 49.625 & 0.154 & 0.917 & 33.255 & 0.854 & 14.069 & 0.869 & 0.000 & 0.010 & 0.000 & 99.753 \\
\hline \multicolumn{14}{|c|}{ Cátions (6 oxigênios) } \\
\hline \multirow[t]{4}{*}{ Associação } & Análise,Perfil & TSI & TAL & $M 1 A L$ & M1TI & MIFE2 & $M 1 C R$ & $M 1 M G$ & M2FE2 & $M 2 M N$ & $M 2 C A$ & M2NA & $M 2 K$ \\
\hline & $p \times\{, b t-p \times-g r t 1$ & 1.877 & 0.023 & 0.016 & 0.001 & 0.124 & 0.000 & 0.860 & 0.925 & 0.028 & 0.046 & 0.002 & 0.000 \\
\hline & $p \times 2, b t-p \times-g r t\}$ & 1.964 & 0.036 & 0.010 & 0.003 & 0.153 & 0.000 & 0.835 & 0.935 & 0.030 & 0.035 & 0.001 & 0.000 \\
\hline & $p \times 3, b t-p \times-g r t 1$ & 1.975 & 0.025 & 0.023 & 0.005 & 0.146 & 0.001 & 0.825 & 0.925 & 0.029 & 0.045 & 0.001 & 0.000 \\
\hline$C-32-3,7$ & $p \times 4, b t-p \times-g \mid t i$ & 1.980 & 0.020 & 0.018 & 0.001 & 0.144 & 0.001 & 0.835 & 0.940 & 0.027 & 0.032 & 0.001 & 0.000 \\
\hline \multirow[t]{4}{*}{$C-32-4$} & $p \times 5, b t-p x-g r t 1$ & 1.965 & 0.035 & 0.014 & 0.005 & 0.156 & 0.000 & 0.825 & 0.930 & 0.028 & 0.039 & 0.003 & 0.000 \\
\hline & $p \times 6, b t-p \times-g t 1$ & 1.970 & 0.030 & 0.014 & 0.000 & 0.146 & 0.000 & 0.840 & 0.948 & 0.030 & 0.021 & 0.000 & 0.000 \\
\hline & $p \times 7, b t-p \times-g r t 1$ & 1.980 & 0.020 & 0.026 & 0.002 & 0.122 & 0.000 & 0.850 & 0.937 & 0.030 & 0.032 & 0.001 & 0.000 \\
\hline & $p \times 8, b t-p \times$-grt 1 & 1.974 & 0.026 & 0.017 & 0.003 & 0.144 & 0.000 & 0.837 & 0.930 & 0.027 & 0.040 & 0.002 & 0.001 \\
\hline
\end{tabular}




\begin{tabular}{|c|c|c|c|c|c|c|c|c|c|c|c|c|c|c|c|}
\hline \multirow[t]{7}{*}{ Associação } & Análise,Perfil & TSI & TAL & $M I A L$ & M1TI & M1FE2 & $M 1 C R$ & MIMG & M2FE2 & $M 2 M N$ & $M 2 C A$ & M2NA & M2K & & \\
\hline & px9,bt-px-grt1 & 1.960 & 0.040 & 0.016 & 0.002 & 0.144 & 0.000 & 0.838 & 0.937 & 0.030 & 0.032 & 0.001 & 0.000 & & \\
\hline & $p \times 10, b t-p x-g r t 1$ & 1.963 & 0.037 & 0.014 & 0.001 & 0.145 & 0.000 & 0.840 & 0.928 & 0.031 & 0.038 & 0.003 & 0.000 & & \\
\hline & $p \times 11, b t-p x-g r t 2$ & 1.976 & 0.024 & 0.022 & 0.002 & 0.139 & 0.000 & 0.837 & 0.931 & 0.031 & 0.035 & 0.003 & 0.000 & & \\
\hline & $p \times 12, b t-p \times-g r t 2$ & 1.975 & 0.025 & 0.023 & 0.002 & 0.149 & 0.000 & 0.826 & 0.930 & 0.030 & 0.038 & 0.002 & 0.000 & & \\
\hline & $p \times 13, b t-p x-g r 2$ & 1.962 & 0.038 & 0.019 & 0.003 & 0.152 & 0.000 & 0.825 & 0.928 & 0.031 & 0.038 & 0.003 & 0.001 & & \\
\hline & $p \times 14, b t-p \times$-grt2 & 1.960 & 0.040 & 0.009 & 0.003 & 0.154 & 0.000 & 0.834 & 0.928 & 0.031 & 0.038 & 0.003 & 0.000 & & \\
\hline \multirow[t]{11}{*}{$C-32-8,11$} & $p \times 15, b t-p x-g r t 2$ & 1.975 & 0.025 & 0.028 & 0.000 & 0.143 & 0.001 & 0.828 & 0.927 & 0.033 & 0.038 & 0.002 & 0.000 & & \\
\hline & $p \times 16, b t-p x-g r t 2$ & 1.968 & 0.032 & 0.018 & 0.003 & 0.145 & 0.000 & 0.834 & 0.937 & 0.030 & 0.033 & 0.000 & 0.000 & & \\
\hline & px17,bt-px-gnt2 & 1.958 & 0.042 & 0.011 & 0.003 & 0.156 & 0.000 & 0.830 & 0.930 & 0.028 & 0.039 & 0.003 & 0.000 & & \\
\hline & $\mathrm{p} \times 18, \mathrm{bt}-\mathrm{px}$-gtt2 & 1.973 & 0.027 & 0.023 & 0.003 & 0.149 & 0.000 & 0.825 & 0.928 & 0.031 & 0.039 & 0.002 & 0.000 & & \\
\hline & $p \times \uparrow 9, b t-p x-g r t 2$ & 1.966 & 0.034 & 0.022 & 0.005 & 0.144 & 0.000 & 0.828 & 0.928 & 0.029 & 0.040 & 0.002 & 0.001 & & \\
\hline & $p \times 20, b t-p x-g r 2$ & 1.965 & 0.035 & 0.020 & 0.004 & 0.154 & 0.001 & 0.821 & 0.919 & 0.031 & 0.048 & 0.001 & 0.001 & & \\
\hline & $\mathrm{p} \times 21, \mathrm{bt}-\mathrm{px}-\mathrm{grt} 2$ & 1.973 & 0.027 & 0.026 & 0.004 & 0.151 & 0.000 & 0.820 & 0.922 & 0.034 & 0.043 & 0.001 & 0.000 & & \\
\hline & $p \times 22, b t-p x-g r t 2$ & 1.968 & 0.032 & 0.016 & 0.001 & 0.137 & 0.000 & 0.845 & 0.933 & 0.030 & 0.036 & 0.000 & 0.001 & & \\
\hline & $p \times 23$, bt-px-grt2 & 1.965 & 0.035 & 0.020 & 0.003 & 0.141 & 0.002 & 0.833 & 0.920 & 0.034 & 0.042 & 0.003 & 0.001 & & \\
\hline & $p \times 24, b t-p x-g r t 2$ & 1.964 & 0.036 & 0.002 & 0.006 & 0.157 & 0.000 & 0.835 & 0.928 & 0.033 & 0.038 & 0.001 & 0.000 & & \\
\hline & $p \times 25$, bt-px-grt2 & 1.969 & 0.031 & 0.020 & 0.002 & 0.152 & 0.002 & 0.825 & 0.929 & 0.031 & 0.038 & 0.001 & 0.000 & & \\
\hline$C-32-16,17$ & $\mathrm{p} \times 26, \mathrm{bt}-\mathrm{px}-\mathrm{grt} 2$ & 1.960 & 0.040 & 0.003 & 0.005 & 0.164 & 0.000 & 0.828 & 0.934 & 0.029 & 0.037 & 0.000 & 0.001 & & \\
\hline \multicolumn{16}{|l|}{ Anfibolio } \\
\hline \multirow[t]{14}{*}{ Associação } & Análise,Perfil & Loc & SIO2 & TIO2 & AL2O3 & FEO & MNO & $M G O$ & CAO & NA2O & $\mathrm{K} 20$ & $\mathrm{~F}$ & $\mathrm{CL}$ & TOTAL & TSI \\
\hline & anf1,grt-nd-bt1 & hd/grt & 40.400 & 2.047 & 12.433 & 20.276 & 0.155 & 7.959 & 10.772 & 1.230 & 1.848 & 0.068 & 0.176 & 97.364 & 6.191 \\
\hline & anf 2, grt-hd-bt1 & $\mathrm{hd} / \mathrm{bt}$ & 40.755 & 1.765 & $\$ 2.484$ & 20.294 & 0.196 & 7.955 & 10.769 & 1.259 & 1.627 & 0.048 & 0.202 & 97.354 & 6.229 \\
\hline & anf3,grt-hd-bt1 & núcleo & 40.428 & 2.074 & 12.543 & 20.784 & 0.150 & 7.657 & 10.767 & 1.456 & 1.673 & 0.194 & 0.187 & 97.913 & 6.186 \\
\hline & anf $4, g r t-h d-b t 1$ & $h d / p x$ & 40.558 & 1.889 & 12.354 & 20.113 & 0.183 & 7.947 & 10.956 & 1.215 & 1.699 & 0.147 & 0.173 & 97.334 & 6.217 \\
\hline & anf5,grt-hd-bt 1 & borda & 40.537 & 1.817 & 12.873 & 19.999 & 0.173 & 7.912 & 10.999 & 1.145 & 1.767 & 0.206 & 0.179 & 97.607 & 6.191 \\
\hline & anf6,grt-hd-bt2 & $\mathrm{hd} / \mathrm{gr}$ & 40.607 & 1.368 & 12.908 & 19.098 & 0.120 & 8.553 & 11.114 & 1.142 & 1.868 & 0.249 & 0.160 & 97.187 & 6.203 \\
\hline & anf7,grt-hd-bt2 & hd/pg & 40.928 & 2.005 & 12.408 & 19.153 & 0.122 & 8.495 & 11.134 & 1.070 & 1.732 & 0.261 & 0.206 & 97.514 & 6.239 \\
\hline & anf8,gtt-hd-bt2 & $\mathrm{hd} / \mathrm{pg}$ & 40.311 & 1.616 & 13.689 & 19.451 & 0.132 & 7.863 & 11.221 & 1.035 & 1.871 & 0.177 & 0.211 & 97.577 & 6.148 \\
\hline & anf9,grt-hd-bt2 & hd/pg & 40.739 & 1.715 & 13.021 & 19.618 & 0.153 & 8.005 & 11.096 & 1.057 & 1.767 & 0.242 & 0.207 & 97.620 & 6.212 \\
\hline & anf 10 , grt-hd-bt2 & núcleo & 41.261 & 2.337 & 12.210 & 19.234 & 0.158 & 8.268 & 11.001 & 1.236 & 1.739 & 0.270 & 0.172 & 97.886 & 6.287 \\
\hline & anft1, grt-hd-bt2 & núcleo & 40.342 & 2.054 & 12.403 & 20.502 & 0.216 & 7.896 & 10.825 & 1.340 & 1.814 & 0.327 & 0.204 & 97.923 & 6.177 \\
\hline & anf12,grt-hd-bt2 & $\mathrm{hd} / \mathrm{bt}$ & 40.437 & 2.169 & 12.407 & 20.376 & 0.219 & 7.942 & 10.801 & 1.310 & 1.813 & 0.113 & 0.184 & 97.771 & 6.182 \\
\hline & anf 13, grt-hd-bt2 & núcleo & 40.590 & 1.980 & 12.573 & 20.299 & 0.135 & 7.943 & 11.019 & 1.269 & 1.805 & 0.228 & 0.198 & 98.039 & 6.193 \\
\hline
\end{tabular}


Cátions (media de 15 exeto $\mathrm{Na}-\mathrm{K}$ e de 13 exeto $\mathrm{Ca}-\mathrm{Na}-\mathrm{K}$ )

Associação Análise,Perfil anf1, grt-hd-bt1 anf2,gr-hd-bt1 anf3,grt-hd-bt1 anf4,grt-hd-bt1 anf5, grt-hd-bt1 anf6,grt-hd-bt2 anf7, grt-hd-bt2

anf8,grt-hd-bt2 anf9,grt-hd-bt2 anf10,grt-hd-bt2 anf11,grt-hd-bt2 anf12,grt-hd-bt2 anf 13, grt-hd-bı?

$\begin{array}{cc}\text { TAL } & \text { CAL } \\ 1.809 & 0.435 \\ 1.771 & 0.476 \\ 1.814 & 0.446 \\ 1.783 & 0.447 \\ 1.809 & 0.507 \\ 1.797 & 0.525 \\ 1.761 & 0.467 \\ 1.852 & 0.607 \\ 1.788 & 0.550 \\ 1.713 & 0.478 \\ 1.823 & 0.413 \\ 1.818 & 0.415 \\ 1.807 & 0.452\end{array}$

CFE3
0.421
0.450
0.383
0.398
0.414
0.449
0.374
0.382
0.388
0.273
0.424
0.408
0.386

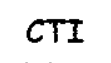

\section{CMG}

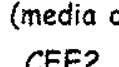

0.236

$\begin{array}{ll}1.818 & 2.080\end{array}$

$\begin{array}{lll}0.203 & 1.813 & 2.046\end{array}$

0.239

1.747

2.046
2.177

\section{CMN BFE2 BMN}

$1.816 \quad 2.098$

0.157

1.801

2.058

0.230

1.931

1.914

$\begin{array}{lll}0.010 & 0.098 & 0.010\end{array}$

$\begin{array}{lll}0.013 & 0.098 & 0.013\end{array}$

$B C A$

BNA

0.197

1.788

2.030

$\begin{array}{llll}0.010 & 0.100 & 0.010 & 1.765\end{array}$

$\begin{array}{llll}0.012 & 0.082 & 0.012 & 1.799\end{array}$

$\begin{array}{llll}0.011 & 0.082 & 0.011 & 1.800\end{array}$

$\begin{array}{llll}0.008 & 0.077 & 0.008 & 1.819\end{array}$

$\begin{array}{llll}0.008 & 0.077 & 0.008 & 1.819 \\ 0.008 & 0.069 & 0.009 & 1.834\end{array}$

0.268

2.036

$\begin{array}{lll}0.010 & 0.078 & 0.010\end{array}$

1.834
1.813

0.237

1.878

2.092

$\begin{array}{llll}0.010 & 0.085 & 0.010 & 1.796\end{array}$

$0.249 \quad 1.810$

2.104

$\begin{array}{llll}0.014 & 0.091 & 0.014\end{array}$

2.120

1.776

$0.227 \quad 1.807$
0.123

0.126

0.125

0.107

0.107
0.096

0.097

0.089
0.100

0.109

0.119

0.123

0.106

\section{ANA}

0.243

0.247

0.254

0.233

0.242

0.220

0.217

0.257

0.279

0.266

0.270
AK

0.361

0.317

0.327

0.332

0.364

0.337

0.364

0.344

0.338

0.354

0.354

0.351
CCL CF $\begin{array}{ll}0.046 \quad 0.033 \\ 0.052 & 0.023\end{array}$ $0.052 \quad 0.023$ $0.049 \quad 0.094$ $0.045 \quad 0.071$ $0.046 \quad 0.099$ $0.041 \quad 0.120$ $0.053 \quad 0.126$ $0.055 \quad 0.085$ $0.054 \quad 0.117$ $0.044 \quad 0.130$ $0.053 \quad 0.158$ $0.048 \quad 0.055$ $0.051 \quad 0.110$

\section{Plagioclásio}

Associação Análise,Perfil

pg1,sin

pg2, sin

C-32-3,7,8,11 pg1,pre

pg2,pre

C-32-4,16,17 pg3,pre

pg4,pre

pg5,pre

pg6,pre

Loc

SIO2

TIO2

borda $\quad 58.569$

núcleo $\quad 58.787$

0.000
0.000

AL2O3 FE2O3 MNO

CAO BAO NA2O

\section{$\mathrm{K} 2 \mathrm{O}$}

CL MGO TOTAL

núcleo $\quad 58.551$

0.000

0.000

$\begin{array}{lll}8.065 & 0.000 & 6.705\end{array}$

0.315

0.000

borda 58.440

0.000

$\begin{array}{llll}0.010 & 7.393 & 0.103 & 7.366\end{array}$

$\begin{array}{lll}0.009 & 0.000 & 100.261\end{array}$

com grt hd 58.275

0.000

$25.780 \quad 0.120$

0.000

$\begin{array}{lll}7.814 & 0.005 & 6.982\end{array}$

$\begin{array}{llll}0.330 & 0.002 & 0.000 & 99.935\end{array}$

$\begin{array}{llll}0.284 & 0.009 & 0.000 & 99.434\end{array}$

$\begin{array}{lllll}\text { com grt,ind } & 59.221 & 0.084 & 26.027 & 0.126\end{array}$

$\begin{array}{llll}0.000 & 7.746 & 0.071 & 6.856\end{array}$

$\begin{array}{llll}0.277 & 0.000 & 0.000 & 99.989\end{array}$

com grt, hd 58.867

$\begin{array}{lll}0.038 & 25.914 & 0.270\end{array}$

0.000

$\begin{array}{lll}7.761 & 0.115 & 6.787\end{array}$

0.299

0.000

99.989
100.451

Cátions (32 oxigênios)

$\begin{array}{cl}\text { Associação } & \begin{array}{c}\text { Análise, Perfil } \\ \text { pg1,sin }\end{array} \\ & \text { pg2,sin } \\ \mathrm{C}-32-3,7,8,11 & \mathrm{pg} 1, \mathrm{pre} \\ & \mathrm{pg} 2, \text { pre } \\ \mathrm{C}-32-4,16,17 & \mathrm{pg3,pre} \\ & \text { pg4,pre } \\ & \text { pg5,pre } \\ & \text { pg6,pre }\end{array}$

$\begin{array}{ccc}\text { SI } & \text { AL } & \text { FE3 } \\ 10.492 & 5.479 & 0.027 \\ 10.486 & 5.496 & 0.008 \\ 10.517 & 5.457 & 0.013 \\ 10.614 & 5.328 & 0.019 \\ 10.510 & 5.460 & 0.016 \\ 10.449 & 5.461 & 0.112 \\ 10.533 & 5.452 & 0.017 \\ 10.521 & 5.454 & 0.036\end{array}$

TI
0.000

\section{$M N$}

\section{$B A$}

CA NA K

$0.000 \quad 0.000$

100.051

\section{Componentes}

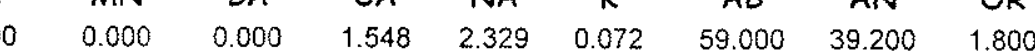

$\begin{array}{lllllllll}0.000 & 0.004 & 0.000 & 1.522 & 2.408 & 0.065 & 60.300 & 38.100 & 1.600\end{array}$

$\begin{array}{lllllllll}0.000 & 0.000 & 0.001 & 1.481 & 2.475 & 0.070 & 61.500 & 36.800 & 1.700\end{array}$

$\begin{array}{lllllllll}0.000 & 0.002 & 0.007 & 1.418 & 2.556 & 0.075 & 63.100 & 35.000 & 1.900\end{array}$

$\begin{array}{lllllllll}0.000 & 0.000 & 0.000 & 1.506 & 2.435 & 0.065 & 60.800 & 37.600 & 1.600\end{array}$

$\begin{array}{lllllllll}0.000 & 0.000 & 0.004 & 1.532 & 2.337 & 0.063 & 59.400 & 39.000 & 1.600\end{array}$

$\begin{array}{lllllllll}0.011 & 0.000 & 0.005 & 1.476 & 2.365 & 0.073 & 60.400 & 37.700 & 1.900\end{array}$

$\begin{array}{llllll}0.005 & 0.000 & 0.008 & 1.486 & 2.352 & 0.068\end{array}$

$60.200 \quad 38.000 \quad 1.700$ 
ANEXO IV - Lista de abreviações para minerais formadores de rochas KRETZ (1983) e SPEAR (1985)

$\begin{array}{llllll}\text { Ab albita } & \text { Aln allanita } & \text { Alm almandina } \\ \text { And andalucita } & \text { Ann anita } & \text { An anortita } \\ \text { Ap apatita } & \text { Bt biotita } & \text { Cpx clinopiroxênio } \\ \text { Di diopsídio } & \text { En enstatita } & \text { Ep epidoto } \\ \text { Fs ferrosilita } & \text { Gn galena } & \text { Grt } & \text { granada } \\ \text { Grs grossulária } & \text { Hbl hornblenda } & \text { Ilm } & \text { ilmenita } \\ \text { Kfs K-feldspato } & \text { Ky cianita } & \text { Mag magnetita } \\ \text { Mc micloclínio } & \text { Mnz monzonita } & \text { Ms } & \text { Moscovita } \\ \text { Or ortoclásio } & \text { Opx } \text { ortopiroxênio } & \text { Phl flogopita } \\ \text { Pl plagioclásio } & \text { Prp piropo } & \text { Px } & \text { piroxênio } \\ \text { Py pirita } & \text { Qtz quartzo } & \text { Sil sillimanita } \\ \text { Srp serpentina } & \text { Tr tremolita } & \text { Ttn titanita } \\ \text { Zrn zircão } & & & \end{array}$




\section{ANEXO V - Descrição petrográfica das amostras utilizadas para as análises geotermobarométricas e isotópicas.}

V-332, granulito charnockítico com granada. Apresenta textura xenoblástica e está constituído por: Qtz (30\%), Or pertítico (20\%), hiperstênio (20\%), Pl An 35 (15\%), Bt (10\%), Grt (5\%), Ttn, Zrne Ap (<1\%). Localmente, por alteraçāo hidrotermal, a Grt está cloritizada, e através de fraturas e da clivagem no Px desenvolvem-se Tr, Chl e carbonatos. O Qtz aparece como cristais grandes com contatos suturados e extinção ondulante marcando uma orientação gnáissica. O Or de grã média a grossa é pertítico tipo stringlets e rods (máximo de $10 \%$ da fase sódica) e tem inclusões de Pl e Qtz. O Pl de grã média é andesina geminada segundo a Lei da Albita, e desenvolve textura mirmequítica nas proximidades de Qtz e Or. A Bt pardo vermelha apresenta-se como cristais finos a médios na matriz, em contato com Grt, como inclusões na Grt, e como remanescentes formados a partir de Grt e hiperstênio. A Grt tem inclusões de Bt, Qtz e Ttn, as quais não se distribuem regularmente. Ocasionalmente a Grt está corroída, formando-se una borda de PI mirmequítico no contato com Or, nesta reação intervém Bt.

Gr-15, gnaisse granolepidoblástico. Constituído por Qtz (40\%), PI An $\operatorname{An}_{25}(30 \%), \mathrm{Mc}(9 \%)$, Bt (15\%), Grt $(5 \%)$, e Mag, Ap (1\%). Os cristais de Qtz de grã grossa tem extinção ondulante. O Pl ocorre em dois arranjos texturais: como cristais granoblásticos de grã médio com geminação da Lei da Albita e ocasionalmente com textura mirmequítica, e como bordas ao redor da Grt e do Qtz incluso na Grt. O Mc, de grã média, é de alta triclinicidade e possui inclusões de Qtz. A lâmina tem varias gerações de Bt: Bt marrom da matriz, Bt verde escuro em contato com a Grt, e Bt simplectítica verde amarelada com PI formada na interação entre Grt e Mc. A Grt apresenta-se como poikiloblastos anedrais de até $0.5 \mathrm{~cm}$ com inclusões ovaladas de Qtz distribuidas aleatoriamente, e como cristais menores euhedrais e subeuhedrais.

Z-365-1, gnaisse granolepidoblástico migmatítico bandado. Apresenta camadas micáceas (mesossoma) de grá fina $(0.2$ a $0.8 \mathrm{~mm})$ e camadas félsicas (leucossomas) de grã grossa (1-2 mm). Constituído por: Qtz (50\%), Pl An 10 (17\%), Mc (12\%), Bt parda (14\%), Grt (6\%), Sil (1\%). O mesossoma corresponde a gnaisse constituído de: Qtz, Or pertitico tipo strings e stringlets que geralmente inverte a Mc, PI subeuhedral geminado segundo a Lei da Albita, Bt pleocroica em todas direções. O Or desenvolve nas bordas pertitas flame de substituição mais grossas e irregulares que às primarias. Cortando estes gnaisses tem-se níveis máficos de Sil prismática (localmente alterada a minerais de argila) e Bt castanha, os quais determinam uma marcante foliação. Ao longo da clivagem da Bt e no limite entre os minerais desenvolve-se Ms em condições retrógradas.

Observam dois tipos de leucossoma: (1) de grã grossa que consiste de Qtz com extinção ondulante, Kfs (principalmente Mc de baixa a média triclinicidade e em menor quantidade Or), Pl e Bt. Dentro dos grandes cristais de Qtz observam-se porções remanescentes de Or pertítico, Pl e Qtz, e também PI mirmequítico corroído e embebido por Kfs. (2) de grä fina constituído de Qtz, Mc, Bt fina, Grt. A Grt, fraturada e deformada, tem algumas inclusões arredondadas de Qtz, Mnz e Sil, está em contato com Bt marrom amarelada, e ocasionalmente observa-se uma borda de PI. O Kfs contêm inclusões de Sil.

Jiménez, D M., (2003) 
C-32, granulito máfico. É granolepidoblástico e está composto por bandas granulíticas marginadas por níveis micáceos foliados de Bt castanha, $\mathrm{Pl}$ e Qtz. As bandas granulíticas granoblásticas consistem de Grt, Opx, Hbl, Pl, Qtz. A lâmina consiste de: Pl An ${ }_{45}(40 \%)$, Qtz (25\%), Bt (25\%), hiperstênio (5\%), Grt (2\%), Hbl (1\%), Or antipertítico (1\%), Ap e opaco (1\%). O Pl é antipertitico, distinguindo-se dois tipos de antipertitas distribuidas perpendicular e paralelamente à foliação. O Qtz é monocristalino com extinção ondulante e forma camadas de até $3 \mathrm{~mm}$. A Bt pardo vermelha encontra-se associada tanto às bandas granuliticas como aos niveis micáceos e como inclusões na Grt. O hiperstênio encontra-se cisalhado e por alteração hidrotermal incipiente forma carbonato, opacos e Chl. A Grt está em paragêneses com Opx, Bt, e ocasionalmente possui inclusões de Bt vermelha. A Hbl é verde e forma-se pela alteração de hiperstênio. A Ap atinge dimensões de até $0.6 \mathrm{~mm}$ e encontra-se associada à Bt dos níveis micáceos.

V-198, ortognaisse com biotita e hornblenda. A lâmina consiste de: Mc pertítico (24\%), PI An 17.5 (30 $\%$ ), Qtz (25\%), Bt (14\%), Hbl (2\%), Mag (5\%), Zrn e Ap (traços). O Mc encontra-se principalmente como cristais milimétricos com pertitas em duas direções e inclusões de Qtz, e como cristais finos. O PI apresenta geminação da Lei da Albita e Periclínio e geralmente desenvolve textura mirmequítica nos contatos com Mc; está sericitizado. O Qtz é de grã grossa com extinção ondulante, e formas alongadas e deformadas. A Bt de grã media a grossa, com pleocroismo de amarelo esverdeado a castanho, e possui inclusões de Qtz, Ap e Zrn; desenvolve simplectitas com Qtz. A Hbl é de grã grossa, com pleocroismo verde escuro e desenvolve-se com a biotita. A Ap apresenta cristais grandes com inclusões de Zrn, e estão relacionados à Bt. Os maiores cristais de $\mathrm{Zrn}$ tem formas arredondadas. A Aln é marrom, pleocroica de amarela a marrom e zonação na cor, apresenta figura flash, e encontra-se associada à Mag.

Gr-29, granulito enderbítico com orto e clinopiroxênio. Apresenta textura gnáissica com bandas quartzo-feldspáticas e de Px, sendo constituído por PI $A n_{31.5}(45 \%)$, Qtz $(35 \%)$, Opx e Cpx (14\%), Bt (4\%), $\mathrm{Hbl}(2 \%)$, Mag, Py, Zrn (traços). O Pl é subeuhedral geminado segundo a Lei da Albita, ocasionalmente os cristais estão deformadas e se reconhecem estruturas zonadas. O Or está em quantidades menores como hóspede em Pl. O Qtz milimétrico anedral, com formas alongadas e extinção ondulante; também se encontra inserido no Pl. Os piroxênios são de grã média a grossa com desenvolvimento de Chl através das fraturas. A Hbl de grã média com pleocroismo de verde claro a verde acastanhado, geralmente associada aos opacos; forma-se também pela alteração do Cpx. A Bt de grã média com pleocroismo vermelho escuro, sem alteração. A Ap está inserida no PI.

Gr-15-a, gnaisse quartzo feldspático com biotita. Constituído por Mc (40\%), PI An $\mathrm{An}_{28}(30 \%)$, Qtz (21\%), Bt $(8 \%)$, opacos (1\%). Os cristais de Mc são pertíticos, e localmente dentro destes se reconhecem porções remanescentes de $\mathrm{Pl}$ mirmequítico. A lâmina contem Or muito fino com pertitas flame de substituição. O Pl é de grã média a grossa, e apresenta-se geminado segundo a Lei da Albita e Periclínio. Desenvolve textura mirmequítica, e geralmente encontra-se alterado a sericita. O Qtz de grã 
média a grossa, com extinção ondulante. A Bt de grã média, alterada a Chl. Ocorre também uma segunda geração de cristais grandes de Ep (zoizita) associados a ilm. A lâmina apresenta saussuritização pela alteração.

A-746, granodiorito gnaissico com hornblenda e biotita. Apresenta textura inequigranular. Observam-se feições ígneas reconheciveis, sendo que a orientação e imbricação do Pl e

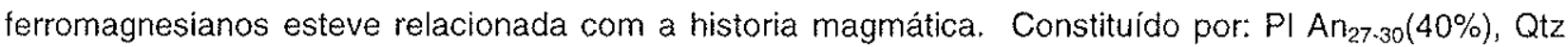
$(30 \%), \mathrm{Bt}(15 \%), \mathrm{Hbl}(10 \%), \mathrm{Mc}(3 \%), \mathrm{Px}(1 \%), \mathrm{Ttn}, \mathrm{Zrn}$ e Ap (traços). O Pl é geminado, disposto na foliação magmatica e com desenvolvimento de mirmequita em contato com Kfs; alguns cristais estão rotacionados e fraturados. O Qtz está em ribons com extinção ondulante. O Mc é límpido, a Bt é amarela esverdeada, e a $\mathrm{Hbl}$ verde. A Ttn apresenta formas rômbicas, e encontra-se associada à $\mathrm{Bt}$; o Zrn está inserido na Bt.

D-982, gnaisse de quartzo-plagioclásio com granada. Apresenta textura granolepidoblástica, sendo constituído por: Qtz $(60 \%)$, PI An $\mathrm{An}_{40}(31 \%)$, Kfs $(3 \%)$, Bt $(3 \%)$, Grt $(1.5 \%)$, opacos $(1.5 \%)$. O Qtz corresponde a cristais de grã grossa de até $2 \mathrm{~cm}$ de cumprimento. O PI encontra-se em duas gerações, uma como cristais de granulação grossa geminados segundo a Lei da Albita que contem antipertitas de Or possiveis resquícios duma fase anterior; a outra como agregados de grã fina associados a Qtz e em menor proporção a Mc. O Mc é de grã fina. A Bt de grã fina a média é marrom, e apresenta simplectitas vermiculares com Qtz. A Grt de grã média, anedral, forma-se em paragênesis com Bt e altera a Ms e Chl. O Zrn está inserido no Qtz.

V-314, gnaisse quartzo feldspático com hornblenda e biotita. Apresenta textura de granoblástica a gnáissica e lâminas muito finas descontinuas de minerais máficos, constituido por: Qtz (46\%), Or (27\%), $\mathrm{PI}$ (andesina 19\%), Hbl (5\%), Mag (2\%), Bt (1\%), Zrn e Ap (traços). O Qtz está como cristais de grã média a grossa com extinção ondulante e como finas inclusões goticulares em Or. O Or é de grã média a grossa, mesopertítico a pertítico, as pertitas se dispõem em duas direções formando ângulo de $30^{\circ}$. $O$ Pl apresenta-se com textura mirmequítica em contato com Or e como antipertitas em Or. A Hbl é de granulação fina a média, verde escura. A Bt marrom, desenvolve simplectitas com Qtz; tanto a Bt, $\mathrm{Hbl}$, Mag e Ap encontram-se associados. A apatita de grã fina a média, algumos cristais euhedrais contem inclusões aciculares e euhedrais dum mineral amarelo de alto relevo? e inclusōes anedrais de $\mathrm{Zrn}$. O Zrn é de granulação média e distinguem-se cristais euhedrais basais, como também anedrais.

V-290, gnaisse sienogranítico. Apresenta textura fanerítica inequigranular fina a média, típica de cristalização de fundido. A lâmina consiste de: Kfs pertítico (51\%), Qtz (40\%), Mag (5\%), PI (3\%), Bt $(1 \%)$, Ttn e Zrn (1\%). O Kfs é pertítico em sua totalidade, as lamellas são compridas e delgadas, seguem a mesma direção ao longo do cristal, e apresenta intercrescimentos mirmequíticos gráficos com Qtz. O Qtz é anedral. O Pl é de grã fino, esta restrito entre o Kfs. A Bt está totalmente cloritizada e 
desenvolve textura simplectítica com Mag. A Ttn está associada à Mag. A Mag distribui-se aleatoriamente. Presença de zircão em quantidades pequenas.

D-986, granulito máfico com orto e clinopiroxênio. Apresenta textura granoblástica, sendo constituído por: Pl An $41.5(52 \%)$, Opx e Cpx (20\%), Hbl e Bt (12\%), Qtz (10\%), Mag (5\%), Kfs (1\%), Zrn e Ap (traços). O PI de grã média a grossa, antipertitico, geminado segundo a Lei da Albita contem inclusões de Qtz, Ap e $\mathrm{Zrn}$, se reconhecem algumos cristais zonados, altera a sericita em pouca quantidade. O Opx é de grão média e cor rosado, e o Cpx de grão média a grossa e verde. A Hbl é verde, e embora não se descarta que esteja em paragênesis, algo de $\mathrm{Hbl}$ se forma pela alteração de $\mathrm{Cpx}$. A Bt é de granulação média, vermelha e está associada à Mag. A Mag forma-se em cercanias aos máficos.

V-309, granulito hornblendico com orto e clinopiroxênio. Apresenta textura nematoblástica, sendo constituído por: $\mathrm{Hbl}(57 \%), \mathrm{Cpx}(24 \%), \mathrm{Opx}(8 \%), \mathrm{Pl}$ (andesina $8 \%)$, Qtz (2\%), Bt (1\%), Zrn, Ap e opacos (traços). A Hbl de granulação média a grossa, tem ligeiro pleocroismo verde, algo de $\mathrm{Hbl}$ gera-se pela alteração do $\mathrm{Px}$. O Opx e $\mathrm{Cpx}$ de grão média, têm leve pleocroismo rosado e verde, respetivamente. $\mathrm{O}$ $\mathrm{Pl}$, de granulação média, tem leve orientação e sericita $<1 \%$. Qtz monocristalino fino com orientação. A Bt de grã fina a média tem pleocroismo vermelho. Desenvolve-se Chl pela alteração de $\mathrm{Hbl}$ e Px. Ap e Zrn como cristais sub-milimétricos.

C-302, gnaisse de quartzo-plagioclásio com biotita. Apresenta textura gnáissica, sendo constituído por: PI An $\mathrm{An}_{34}(44 \%), \mathrm{Qtz}(34 \%), \mathrm{Bt}(20 \%)$, Mc (2\%), opaco, Zrn e Ap (traços). O PI de grä grossa geminado segundo a Lei da Albita e Pericínio, é antipertítico (Mc como fase hospedada no Pl sericitizado), e tern dois tipos de inclusões, umas arredondadas de $Q t z$, e outras euhedrais quadradas de Kfs (possível Mc), orientadas. Esta última, contem inclusōes de Ap anedral. O Qtz é de granulação média a grossa com extinção ondulante. A Bt de grã média, vermelha possui inclusões de Zrn com halo pleocroico, e desenvolvimento de esfena atravéz da exfoliação do cristal. Opaco associado à Bt. Ap de granulação média inserida em $\mathrm{Bt}$ e Pl, e Zrn.

C-299, gnaisse de plagioclásio-quartzo com biotita, piroxênio e hornblenda. Apresenta textura gnáissica, sendo constituído por: Pl An $n_{34}(45 \%)$, Qtz (30\%), Bt (15\%), Opx e Cpx (5\%), Hbl (5\%), Zrn e Ap (traços). O plagioclásio de grã média possui geminação da Lei da Albita e em menor proporção da Lei do Periclínio, é antipertítico (Or com formas quadradas) e desenvolve nas bordas mirmequitas. O Qtz é de granulação média, anedral, ondulante. A Bt com pleocroismo de amarelo pálido a marrom, possui inclusões de Zrn e desenvolve textura simplectítica. O Opx tem cores de interferência de primeira ordem e tons rosa, e o $\mathrm{Cpx}$ extinção $45^{\circ}$ e pleocroismo verde. A Hbl com pleocroismo verde a marrom esverdeado possui inclusōes de Qtz, forma-se pela alteracao de Opx e possivelmente Bt?. A Ap de grão média, abundante, contem inclusões euhedrais orientadas dum mineral de alto relevo (não distinguido ao microscópio óptico), e anedrais. Desenvolvimento de simplectitas de opaco e Qtz pela reação de Bt e Opx. 
C-271, granulito enderbítico com orto e clinopiroxênio. Apresenta textura gnáissica, sendo constituído por: PI $\mathrm{An}_{34}(40 \%)$, Qtz (30\%), Opx e Cpx (17\%), Bt (12\%), Mag (1\%), Zrn e Ap (traço). O Pl corresponde a cristais de granulação média a grossa, subeuhedrais, geminados segundo a Lei da Albita e Albita interrompida com inclusões de Qtz, algumos cristais são antipertíticos (exsolução de Or). O Qtz apresentasse como cristais de grã média, ondulantes e bordas suturadas, e como inclusões em Pl. Os dois Px são de granulação média a grossa, o Opx bordeja ao $\mathrm{Cpx}$, e este último altera a Chl através das fraturas. A Bt é vermelha e algumos cristais formam-se pela alteração de Px. A Ap e de grã média.

D-806, granulito bandado com ortopiroxênio, clinopiroxênio e hornblenda. Apresenta textura granoblástica. As bandas máficas estão constituídas por: Opx e Cpx (35\%), Or (30\%), PI $\mathrm{An}_{38}(15 \%)$, $\mathrm{Hbl}(10 \%)$, Qtz (8\%), Bt (2\%), e as félsicas por: Or (65\%), PI (19\%), Qtz (10\%), e Opx, Cpx e Hbl $(6 \%)$. O Or e pertítico com inclusões de Qtz e Zm, apresenta intercrescimentos gráficos. O Pl de grā média é geminado segundo a Lei da Albita e Periclínio e desenvolve mirmequitas vermiculares nas bordas dos cristais em contato com Or média. O quartzo é de granulação média a grossa. Os dois Px são de grã média a grossa, particularmente o Opx tem pleocroismo rosa e o Cpx verde, e esta cloritizado. A Hbl forma-se pela alteração do Px e freqüentemente apresentasse bordejando os minerais opacos. A Bt é de granulação média e tem textura simplectítica com Qtz. Zrn e Aln? em quantidades menores. Presença de Mag e Py. 
ANEXO VI- Dados isotópicos U.Pb SHRIMP em zircão

\begin{tabular}{|c|c|c|c|c|c|c|c|c|c|c|c|c|c|c|c|c|c|c|c|c|c|c|c|}
\hline \multirow[t]{2}{*}{ Análise } & \multirow{2}{*}{$\begin{array}{c}\% \\
{ }^{200} \mathrm{~Pb} \\
\end{array}$} & \multirow{2}{*}{$\left.\begin{array}{c}U \\
(\mathrm{ppm})\end{array}\right)$} & \multirow{2}{*}{$\begin{array}{c}\text { Th } \\
(\mathrm{ppm})\end{array}$} & \multirow[t]{2}{*}{ Th/U } & \multirow{2}{*}{$\begin{array}{c}\mathrm{Pb} \\
\{\mathrm{ppm}\}\end{array}$} & \multicolumn{4}{|c|}{ Razóes medidas ${ }^{a}$} & \multicolumn{9}{|c|}{ Razões radiogenicas ${ }^{b}$} & \multicolumn{5}{|c|}{ Ifade (Ma) } \\
\hline & & & & & & ${ }^{38} \mathrm{U} /{ }^{206} \mathrm{~Pb}$ & \pm & ${ }^{207} \mathrm{~Pb} /{ }^{206} \mathrm{~Pb}$ & \pm & ${ }^{238} \mathrm{U}^{206 \mathrm{~Pb}}$ & \pm & ${ }^{207} \mathrm{~Pb} / /^{206} \mathrm{~Pb}$ & \pm & ${ }^{207} \mathrm{~Pb} /{ }^{235} \mathrm{U}$ & \pm & ${ }^{206} \mathrm{~Pb} /{ }^{238} \mathrm{U}$ & \pm & err corr & ${ }^{206} \mathrm{~Pb} /{ }^{238} \mathrm{U}$ & \pm & ${ }^{207} \mathrm{pb} /{ }^{200} \mathrm{pb}$ & \pm & $\%$ Disc. \\
\hline V-198-1 & 1.67 & 38 & 22 & 0.59 & 6.0 & 5.43 & 2.2 & 0.0782 & 2.6 & 5.52 & 2.3 & 0.0640 & 11 & 1.60 & 11 & 0.1811 & 2.3 & 0.214 & 1073 & 23 & 743 & 220 & $-\frac{3 t}{4}$ \\
\hline$|v-198-2(b)|$ & 0.19 & 338 & 89 & 0.27 & 49.1 & 5.90 & 1.9 & 0.0739 & 0.9 & 5.92 & 1.9 & 0.07237 & 1.3 & 1.687 & 2.4 & 0.1690 & 1.9 & 0.823 & 1007 & 18 & 996 & 27 & -1 \\
\hline V-198-3 & 0.45 & 174 & 61 & 0.36 & 30.7 & 4.86 & $\{.8$ & 0.0738 & 1.4 & 4.839 & 1.8 & 0.0749 & 2.1 & 2.113 & 2.8 & 0.2046 & 1.8 & 0.654 & 1200 & 20 & 1067 & 42 & -12 \\
\hline$V-198-4$ & 0.01 & 99 & 38 & 0.40 & 15.8 & 5.38 & 2 & 0.0824 & 1.9 & 5.39 & 2.0 & 0.0824 & 2.4 & 2.109 & 3.2 & 0.1857 & 2.0 & 0.642 & 1098 & 21 & 1255 & 48 & 12 \\
\hline $6-198-5(n)$ & 0.12 & 227 & 90 & 0.41 & 38.7 & 5.04 & 1.7 & 0.0779 & 1.0 & 5.047 & 1.7 & 0.0769 & 1.5 & 2.100 & 2.3 & 0.1981 & 1.7 & 0.757 & 1155 & 19 & 1118 & 30 & -4 \\
\hline$V-198-6(n)$ & 0.01 & 387 & 171 & 0.46 & 64.4 & 5.16 & 1.7 & 0.0795 & 0.8 & 5.166 & 1.7 & 0.07942 & 1.0 & 2.120 & 2.0 & 0.1936 & 1.7 & 0.859 & 1141 & 18 & 1183 & 20 & 4 \\
\hline$V-198.7(b)$ & 0.99 & 80 & 34 & 0.44 & 11.8 & 5.81 & 1.9 & 0.0815 & 1.8 & 5.87 & 2.0 & 0.0732 & 4.6 & 1.718 & 5.0 & 0.1703 & 2.0 & 0.392 & 1014 & 18 & 1019 & 93 & 1 \\
\hline V-198-8 & 0.80 & 319 & 64 & 0.21 & 52.0 & 5.27 & 1.7 & 0.0765 & 1.7 & 5.317 & 1.8 & 0.0696 & 6.4 & 1.81 & 6.6 & 0.1881 & 1.8 & 0.273 & 1111 & 18 & 918 & 130 & -21 \\
\hline$V-198-9$ & 0.31 & 197 & 45 & 0.24 & 28.9 & 5.87 & 1.9 & 0.0731 & 1.2 & 5.83 & 1.9 & 0.0706 & 2.2 & 1.654 & 2.9 & 0.1700 & 1.9 & 0.654 & 1012 & 18 & 946 & 44 & -7 \\
\hline $\mid v-198-10\langle b|$ & 0.13 & 495 & 209 & 0.44 & 74.9 & 5.67 & 1.7 & 0.0743 & 0.7 & 5.679 & 1.7 & 0.07322 & 0.94 & 1.778 & 2.0 & 0.1761 & 1.7 & 0.876 & 1045 & 16 & 1020 & 19 & -2 \\
\hline$|v-198-11(n)|$ & 0.09 & 202 & 68 & 0.35 & 34.7 & 5.00 & 2.1 & 0.0782 & 1.1 & 5.00 & 2.1 & 0.07743 & 1.1 & 2.134 & 2.4 & 0.1999 & 21 & 0.884 & 1175 & 23 & 1132 & 22 & -4 \\
\hline $1-198-12(b)$ & 0.24 & 411 & 140 & 0.35 & 61.0 & 5.78 & 1.7 & 0.0739 & 0.9 & 5.802 & 1.7 & 0.07194 & 1.3 & 1.709 & 2.1 & 0.1723 & 1.7 & 0.802 & 1025 & 16 & 984 & $2 \hat{\theta}$ & -4 \\
\hline $6 r-29-1$ & 0.06 & 1066 & 185 & 0.18 & 162 & 5.652 & 1.3 & 0.07634 & 0.39 & 5.656 & 1.3 & 0.07583 & 0.44 & 1.849 & 1.4 & 0.1768 & 1.3 & 0.945 & 1050 & 12 & 1091 & 8.9 & 4 \\
\hline$G r-29-2$ & 0.04 & $\$ 214$ & 332 & 0.28 & 162 & 6.428 & 1.3 & 0.07339 & 0.40 & 6.430 & 4.3 & 0.07309 & 0.45 & 1.567 & 1.4 & 0.1555 & 1.3 & 0.944 & 932 & 11 & 1017 & 9.1 & 8 \\
\hline $6 r-29-3$ & 0.03 & 1312 & 290 & 0.23 & 203 & 5.560 & 1.3 & 0.07666 & 0.35 & 5.561 & 1.3 & 0.07643 & 0.38 & 1.895 & 1.3 & 0.1798 & 1.3 & 0.960 & 1086 & 13 & 1106 & 7.5 & 4 \\
\hline $6 r-29-4$ & 0.06 & 877 & 72 & 0.08 & 113 & 6.693 & 1.3 & 0.07302 & 0.51 & 6.697 & 1.3 & 0.07251 & 0.65 & 1.493 & 1.4 & 0.1493 & 1.3 & 0.893 & 897 & 11 & 1000 & 13 & 10 \\
\hline $6 r-29-5$ & 0.14 & $\$ 280$ & 378 & 0.30 & 165 & 6.671 & 1.5 & 0.08819 & 0.62 & 6.681 & 1.5 & 0.08702 & 0.67 & 1.796 & 1.6 & 0.1497 & 1.5 & 0.911 & 899 & 12 & 1361 & 13 & 34 \\
\hline $6 r-29-6$ & 0.13 & 1611 & 159 & 0.10 & 154 & 9.00 & 1.4 & 0.0803 & 2.00 & 9.01 & 1.4 & 0.0792 & 2.1 & 1.213 & 2.5 & 0.1110 & 1.4 & 0.573 & 679 & 9.2 & 1178 & 41 & 42 \\
\hline $6 r-29-7$ & 0.47 & 1500 & 304 & 0.21 & 162 & 7.97 & 1.3 & 0.0924 & 4.50 & 8.01 & 1.3 & 0.0883 & 4.9 & 1.521 & 5.0 & 0.1249 & 1.3 & 0.258 & 759 & 9.3 & 1390 & 93 & 45 \\
\hline$G r-29-8$ & 0.02 & 898 & 40 & 0.05 & 175 & 4.398 & 1.3 & 0.08903 & 0.34 & 4.399 & 1.3 & 0.08889 & 0.36 & 2.786 & 1.3 & 0.2273 & 1.3 & 0.964 & 1320 & 15 & 1402 & 6.3 & 6 \\
\hline$G r-29-9$ & 0.07 & 1256 & 248 & 0.20 & 180 & 5.985 & 1.6 & 0.07634 & 0.49 & 5.989 & 1.6 & 0.07578 & 0.53 & 1.744 & 1.7 & 0.1670 & 1.6 & 0.947 & 995 & 15 & 1089 & 11 & 9 \\
\hline$G r-29-10$ & 0.11 & 869 & 40 & 0.05 & 92.6 & 8.07 & 1.3 & 0.07942 & 0.49 & 8.07 & 1.3 & 0.07852 & 0.59 & 1.341 & 1.4 & 0.1239 & 1.3 & 0.910 & 753 & 9.2 & 1160 & 12 & 35 \\
\hline$G r-29-11$ & 0.64 & 564 & $\$ 36$ & 0.25 & 74.2 & 6.536 & 1.3 & 0.08395 & 0.52 & 6.579 & 1.3 & 0.0785 & 3.0 & 1.646 & 3.2 & 0.1520 & 1.3 & 0.411 & $9 ! 2$ & 11 & 1160 & 59 & 21 \\
\hline$G r-29-12$ & 0.03 & 634 & 160 & 0.26 & 119 & $4.5 \varepsilon 6$ & 1.3 & 0.09013 & 0.48 & 4.567 & 1.3 & 0.08988 & 0.50 & 2.714 & 1.4 & 0.2190 & 1.3 & 0.934 & 1276 & 15 & 1423 & 9.6 & 10 \\
\hline $6 r-29-13$ & & 745 & 66 & 0.09 & 96.8 & 6.612 & 1.3 & 0.07362 & 0.52 & 6.611 & 1.3 & 0.07375 & 0.52 & 1.538 & 1.4 & 0.1513 & 1.3 & 0.927 & 908 & 11 & 1035 & 11 & 12 \\
\hline$G r-29-14$ & 0.03 & 1077 & 197 & 0.19 & 172 & 5.392 & 1.5 & 0.07792 & 0.59 & 5.393 & 1.5 & 0.07770 & 0.61 & 1.986 & 1.7 & 0.1854 & 1.5 & 0.930 & 1097 & 16 & 1139 & 12 & 4 \\
\hline $6 r-15 A-3$ & 0.12 & 431 & 208 & 0.50 & 60.4 & 6.130 & 2.4 & 0.07336 & 0.68 & 6.14 & 2.4 & 0.07243 & 0.82 & 1.627 & 2.6 & 0.1629 & 2.4 & 0.948 & 973 & 22 & 998 & 17 & 2 \\
\hline $6 r-15 A-2$ & 0.04 & 655 & 321 & 0.51 & 92.5 & 6.080 & 2.4 & 0.07300 & 0.86 & 6.09 & 2.4 & 0.07268 & 0.69 & 1.646 & 2.5 & 0.1643 & 2.4 & 0.962 & 981 & 22 & 1005 & 14 & 2 \\
\hline $6 r-15 A-3$ & 0.01 & 637 & 269 & 0.44 & 90.0 & 6.084 & 1.3 & 0.07361 & 0.52 & 6.085 & 1.3 & 0.07350 & 0.54 & 1.665 & 1.4 & 0.1643 & 1.3 & 0.923 & 981 & 12 & 1028 & 14 & 5 \\
\hline $6 r \cdot 15 A-4$ & 0.03 & 470 & 486 & 1.07 & 66.5 & 6.070 & 1.3 & 0.07292 & 0.62 & 6.071 & 1.3 & 0.07270 & 0.68 & 1.651 & 1.5 & 0.1647 & 1.3 & 0.887 & 983 & 12 & 1006 & 14 & 2 \\
\hline
\end{tabular}




\begin{tabular}{|c|c|c|c|c|c|c|c|c|c|c|c|c|c|c|c|c|c|c|c|c|c|c|c|}
\hline Análise & \multirow{2}{*}{$\begin{array}{c}\%_{6} \\
{ }^{208} \mathrm{~Pb}\end{array}$} & \multirow{2}{*}{$\begin{array}{c}U \\
\text { (pp:s) }\end{array}$} & \multirow{2}{*}{$\begin{array}{c}\mathrm{Th} \\
\text { (ppm) }\end{array}$} & \multirow[t]{2}{*}{$T h / N$} & \multirow{2}{*}{$\begin{array}{c}\mathrm{Pb} \\
(\mathrm{ppm})\end{array}$} & \multicolumn{4}{|c|}{ Rozões medidos ${ }^{a}$} & \multicolumn{9}{|c|}{ Razões radiogenicas ${ }^{b}$} & \multicolumn{5}{|c|}{ Idade (Mo) } \\
\hline $6 \Gamma-15 A-5$ & & & & & & ${ }^{238} \mathrm{U} \mathrm{J}^{206} \mathrm{~Pb}$ & \pm & ${ }^{207} \mathrm{~Pb} /{ }^{206} \mathrm{~Pb}$ & \pm & ${ }^{205} \mathrm{~Pb} / /^{238} \mathrm{U}$ & \pm & ${ }^{207} \mathrm{~Pb} /{ }^{206} \mathrm{~Pb}$ & \pm & $207 \mathrm{~Pb} /{ }^{235} \mathrm{U}$ & \pm & ${ }^{206} \mathrm{~Pb} / /^{238} \mathrm{U}$ & \pm & err corr & ${ }^{206} \mathrm{~Pb} /{ }^{238} \mathrm{U}$ & \pm & ${ }^{207} \mathrm{~Pb} /{ }^{206} \mathrm{~Pb}$ & \pm & $\%$ Disc. \\
\hline$G_{r}-15 A-6$ & 0.00 & 897 & 312 & 0.36 & 127 & 6.060 & 1.8 & 0.07355 & 0.46 & 6.06 & 1.8 & 0.07337 & 0.49 & 1.670 & 1.9 & 0.1650 & 1.8 & 0.966 & 985 & 17 & 1024.2 & 9.8 & 4 \\
\hline$G r-15 A-7$ & 0.08 & 429 & 254 & 0.61 & 61.1 & 6.040 & 1.3 & 0.07381 & 0.65 & 6.040 & 1.3 & 0.07381 & 0.67 & 1.685 & 1.5 & 0.1656 & 1.3 & 0.896 & 988 & 12 & 1036 & 13 & 5 \\
\hline $6 \Gamma-15 A-8$ & 0.03 & 484 & 563 & 1.20 & 87.5 & 6.150 & 1.8 & 0.07335 & 0.64 & 6.16 & 1.8 & 0.07270 & 0.73 & 1.828 & 1.9 & 0.1624 & 1.8 & 0.926 & 970 & 16 & 1006 & 15 & 4 \\
\hline$G r-15 A-9$ & & 284 & 360 & 0.90 & 58.2 & 6.135 & 1.4 & 0.07269 & 0.70 & 6.137 & 1.4 & 0.07245 & 0.75 & 1.628 & 1.5 & 0.1630 & 1.4 & 0.875 & 973 & 12 & 999 & 15 & 3 \\
\hline$G r-15 A-10$ & 0.06 & $\begin{array}{l}204 \\
460\end{array}$ & 759 & 0.62 & 37.2 & 6.091 & 1.3 & 0.07333 & 0.87 & 6.088 & 1.3 & 0.07371 & 0.90 & 1.669 & 1.6 & 0.1643 & 1.3 & 0.831 & 980 & 12 & 1034 & 18 & 5 \\
\hline$G r-15 A-11$ & 0.12 & 377 & 219 & 0.49 & 66.1 & 5.975 & 1.3 & 0.07361 & 0.60 & 5.978 & 1.3 & 0.07313 & 0.67 & 1.687 & 1.5 & 0.1673 & 1.3 & 0.890 & 997 & 12 & 1017 & 14 & 2 \\
\hline $6 r+15 A-12$ & 0.08 & 447 & $\begin{array}{l}210 \\
335\end{array}$ & 0.59 & 83.2 & 6.094 & 1.3 & 0.07361 & 0.65 & 6.102 & 1.3 & 0.07260 & 0.83 & 1.640 & 1.6 & 0.1639 & 1.3 & 0.849 & 978 & 12 & 1003 & 17 & 2 \\
\hline \multirow{2}{*}{ Análise } & $\%$ & $u$ & Th & 0.17 & 64.2 & 5.983 & 1.3 & 0.07323 & 0.60 & 5.988 & 1.3 & 0.07256 & 0.73 & 1.571 & 1.5 & 0.1670 & 1.3 & 0.878 & 996 & 12 & 1002 & 15 & 1 \\
\hline & ${ }^{206} \mathrm{pb}$ & $(\mathrm{ppm})$ & (ppm) & $10 / 0$ & $\left|\begin{array}{c}0 \\
(\mathrm{ppm})\end{array}\right|$ & \multicolumn{4}{|c|}{ Razö̀es medidas } & \multicolumn{9}{|c|}{ Razöes radiagenicas ${ }^{c}$} & \multicolumn{2}{|c|}{ Idade (Ma) } & & & \\
\hline$A-746-1$ & 6.38 & 39 & 30 & 0.79 & 0.9 & $\frac{{ }^{230} U / /^{20} \mathrm{~Pb}}{37.25}$ & $\frac{ \pm}{34}$ & $\frac{{ }^{207} \mathrm{~Pb} /{ }^{206} \mathrm{~Pb}}{0.7715}$ & \pm & $\frac{{ }^{238} \mathrm{U} /{ }^{208} \mathrm{~Pb}}{307}$ & \pm & ${ }^{207} \mathrm{~Pb} /{ }^{206} \mathrm{~Pb}$ & \pm & ${ }^{207} \mathrm{~Pb} /{ }^{235} \mathrm{U}$ & \pm & ${ }^{206} \mathrm{~Pb} /{ }^{23 e}$ & \pm & err cort & ${ }^{206} \mathrm{~Pb} /{ }^{238} \mathrm{U}$ & \pm & & & \\
\hline$A+746-2$ & 2.88 & 164 & 304 & 1.91 & 3.7 & 38.09 & 3.4 & 0.0715 & 8.0 & 38.7 & 3.4 & 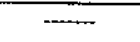 & - & - & - & 0.02585 & 3.4 & - & 165 & 8.8 & & & \\
\hline$A-746-3$ & 17.27 & 24 & 20 & 0.84 & 0.6 & 34.76 & 2.7 & 0.0597 & 3.9 & 38.6 & 2.7 & 0.0496 & 4.8 & 0.1771 & 5.5 & 0.02591 & 2.7 & 0.48296 & 164.9 & 6.6 & & & \\
\hline$A-746-4$ & 3.01 & 325 & 673 & 2.14 & 7.5 & 37.30 & 4.0 & 0.0944 & 8.5 & 36.7 & 4.0 & 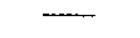 & - & - & - & 0.0272 & 4.0 & - & 173 & 8.7 & & & \\
\hline A-746.5 & 6.41 & 62 & 71 & 1.19 & $\{.4$ & 39.37 & 2.4 & 0.0540 & 2.8 & 37.89 & 2.4 & 0.0446 & 3.7 & 0.1514 & 4.4 & 0.02639 & 2.4 & 0.54403 & 168 & 6.4 & & & \\
\hline A-746-6 & 6.68 & 65 & 58 & 0.92 & 1.6 & 35.53 & 3.0 & 0.0666 & 6.2 & 40.8 & 3.0 & - & - & - & - & 0.02453 & 3.0 & - & 156 & 6.3 & & & \\
\hline A-746-7 & 10.66 & 57 & 49 & 0.90 & 1.4 & 35.92 & $\begin{array}{l}3.1 \\
3.1\end{array}$ & 0.0673 & 7.1 & 36.3 & 3.1 & - & - & {[} & - & 0.02755 & 3.1 & - & 175 & 6.5 & & & \\
\hline A.746-8 & 7.02 & 33 & 27 & 0.84 & 0.8 & 37.59 & $\begin{array}{l}3.1 \\
5.5\end{array}$ & 0.0679 & 6.0 & 37.0 & 3.1 & $\ldots$ & - & + & -- & 0.02706 & 3.1 & {$[-$} & 172 & 6.4 & & & \\
\hline$A-746-9$ & 8.66 & 53 & 58 & 1.12 & 1.2 & 37.62 & 3.1 & $\begin{array}{l}0.0750 \\
0.0685\end{array}$ & 11.8 & $\begin{array}{l}39.2 \\
39.5\end{array}$ & 5.5 & - & - & - & - & 0.0255 & 5.5 & -- & 162 & 11 & & & \\
\hline$A-746.10$ & 3.42 & 62 & 58 & 0.97 & 1.5 & 36.04 & 3.0 & $\begin{array}{l}0.0685 \\
0.0677\end{array}$ & $\begin{array}{l}6.2 \\
6.0\end{array}$ & $\begin{array}{l}39.5 \\
36.9\end{array}$ & $\begin{array}{l}3.1 \\
3.0\end{array}$ & $\overline{0.0503}$ & $-\overline{8}$ & $\bar{\square}$ & - & 0.02531 & 3.1 & 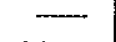 & 161 & 6.7 & & & \\
\hline$A-746-11$ & 3.65 & 61 & 59 & 1.01 & 1.3 & 38.79 & 3.0 & 0.0683 & $\begin{array}{l}6.0 \\
5.7\end{array}$ & $\begin{array}{l}36.9 \\
40.0\end{array}$ & $\begin{array}{l}3.0 \\
3.0\end{array}$ & $\begin{array}{l}0.0503 \\
0.0442\end{array}$ & $\begin{array}{l}8.3 \\
8.2\end{array}$ & 0.188 & 8.8 & 0.02713 & 3.0 & 0.34186 & 173 & 6.4 & & & \\
\hline$A-746-12$ & 3.27 & 164 & 280 & 1.76 & 3.8 & 37.56 & 2.6 & 0.0533 & 3.9 & 38.3 & 2.6 & $\begin{array}{l}0.0442 \\
0.0389\end{array}$ & $\begin{array}{l}9.2 \\
5.5\end{array}$ & $\begin{array}{l}0.152 \\
0.1403\end{array}$ & $\begin{array}{l}9.6 \\
6.1\end{array}$ & $\begin{array}{l}0.02500 \\
0.02614\end{array}$ & $\begin{array}{l}3.0 \\
2.6\end{array}$ & $\begin{array}{l}0.30991 \\
0.43337\end{array}$ & $\begin{array}{l}159 \\
166\end{array}$ & $\begin{array}{l}6.0 \\
6.4\end{array}$ & & & \\
\hline
\end{tabular}

- Todos os erros são a nivel de 10

${ }^{3}$ Razdes corregidas para $\mathrm{Pb}$ comum usando o ${ }^{204} \mathrm{pb}$ medido

${ }^{\mathrm{C}}$ Razסes corregidas para $\mathrm{Pb}$ comum assumindo idade concordante ${ }^{206} \mathrm{~Pb} l^{233} \mathrm{U} .{ }^{206} \mathrm{~Pb} f^{232} \mathrm{Th}$

Disc $=$ discordancia

As lineas em cursiva representam os análises usados para calcular a iđade ou idades médias. (b)análises borda ( $(\Omega)$ análises núcleo 
ANEXO VII - Dados analiticos ${ }^{40} \mathrm{Ar} /{ }^{39} \mathrm{Ar}$.

\begin{tabular}{|c|c|c|c|c|c|c|c|c|c|c|c|c|c|c|c|c|c|c|c|}
\hline Run ID\# & Sample & aterias & $\begin{array}{l}\text { Age } \\
\text { (Ma) }\end{array}$ & $\stackrel{ \pm}{ \pm}$ & $40 / 39$ & $38 / 39$ & $37 / 39$ & $36 / 39$ & $40^{*} / 39$ & Rad & $J$ & \pm & Discr. & \pm & $\begin{array}{l}\text { Ar } 40 \\
(n A)\end{array}$ & $\begin{array}{l}\text { Arta } \\
\text { (mols) }\end{array}$ & $\begin{array}{l}\text { Laser } \\
\text { (W) }\end{array}$ & Irrad. & Run Date \\
\hline 1447-01A & D-986 & Homblenda & -2684.29 & 5511.72 & -11.41432 & 0.02889 & 101.08460 & 0.27125 & -89.32827 & 731.8 & 0.0086664 & $5.40 \mathrm{E}-06$ & 1.0060 & 0.0010 & 0.0004 & $4.13 E-18$ & 0.6 & SPAO2 & 03 \\
\hline 1447.018 & D.986 & Homblenda & 0.00 & 795.97 & -1619.00400 & 0.64557 & 276.69580 & 0.67178 & -2182.55000 & 110.9 & 0.0086664 & $5.40 E-06$ & 1.0060 & 0.0010 & 0.0540 & $1.03 E-15$ & 11 & SPAO203-71 & $03 / 23 / 03$ \\
\hline $1447.01 \mathrm{C}$ & D.986 & Homblenda & 0.00 & 638.63 & -1523.19900 & 0.28681 & 36.32349 & 0.67916 & -1762.00700 & $\$ 13.0$ & 0.0086664 & $5.40 E-06$ & 1.0060 & 0.0010 & 0.1030 & $1.98 E-15$ & 1.6 & SPA0203-71 & $03 / 23 / 03$ \\
\hline 1447-01D & D-986 & Homblenda & 6751.47 & $\begin{array}{l}1782.08 \\
55416\end{array}$ & 6010.43200 & 0.38208 & 87.76076 & 5.18151 & 4753.59300 & 74.6 & 0.0086664 & $5.40 E-06$ & 1.0060 & 0.0010 & 0.1827 & $3.47 E-15$ & 2.2 & SPA0203-71 & $03 / 23 / 03$ \\
\hline $1447-01 \mathrm{E}$ & D-986 & Homblenda & 8716 & 554.16 & 5299.06200 & 0.21349 & 0.00000 & 2.16592 & 4659.00000 & 87.9 & 0.0086864 & 5.40 & 1.0060 & 0.0010 & 0.4647 & $8.89 E-15$ & 2.8 & SPA0203-71 & $03 / 23 / 03$ \\
\hline $1447-01 \mathrm{~F}$ & D-986 & Homblenda & 8019.12 & 232.68 & 9631.06900 & 0.21294 & 43.80813 & 0.64881 & 9715.66300 & 98.0 & 0.0086664 & $5.40 E-06$ & 1.0060 & 0.0010 & 2.9091 & $5.51 \mathrm{E}-14$ & 3.6 & SPA0203-71 & $03 / 23 / 03$ \\
\hline $1447-01 G$ & D-986 & Homblenda & 8080.88 & 153.47 & 9918.12700 & 0.07065 & 31.36881 & 0.21941 & 10058.03000 & 99.4 & 0.0086664 & $5.40 E-06$ & 1.0060 & 0.0010 & 4.4817 & $8.51 E-14$ & 4.5 & SPA0203-71 & 103 \\
\hline $1447.01 \mathrm{H}$ & D-986 & Hombienda & 6064.05 & 23.55 & 3152.25300 & 0.04056 & 35.41477 & 0.05784 & 3210.86900 & 99.5 & 0.0086664 & $5.40 \mathrm{E}-06$ & 1.0060 & 0.0010 & 16.5301 & $3.14 E-13$ & 5.2 & SPA0203-71 & $03 / 23 / 03$ \\
\hline $1447.02 \mathrm{~A}$ & 0.986 & Homblenda & 32.24 & 56.95 & 5960.36400 & 0.07680 & 10.18761 & 0.34501 & 5897.73700 & 98.3 & 0.0086664 & 5.40 & 1.00 & 1.0013 & 11.2694 & $2.14 \mathrm{E}-13$ & .5 & & \\
\hline 1447.028 & D.986 & Homblenda & 5788.82 & 46.29 & 2734.89200 & $-0,00268$ & 2.46053 & -0.00279 & 2740.23100 & 100.0 & 0.0086664 & $5.40 \mathrm{E}-06$ & 1.0061 & 0.0013 & 3.3812 & $6.43 E-14$ & 3.5 & SPA0203.71 & $03 / 26 / 03$ \\
\hline $1447.02 \mathrm{C}$ & D-986 & Homblenda & 8184.37 & 650.18 & 8920.96900 & -0.06170 & 253.57030 & 0.05035 & 10658.67000 & 100.1 & $0.008 \varepsilon 664$ & $5.40 \varepsilon-06$ & 1.0061 & 0.0013 & 2.6995 & $5.10 E-14$ & 4.7 & SPA0203-71 & $3 / 26 / 03$ \\
\hline $1447-020$ & D-986 & Homblenda & 6037.17 & 640.89 & 2747.88400 & -0.25310 & 165.17690 & -0.22316 & 3161.67400 & 102.9 & 0.0086664 & $5.40 E-06$ & 1.0061 & 0.0013 & 0.2103 & $4.01 E-15$ & 5.0 & SPA0203.71 & $03 / 26 / 03$ \\
\hline $1447-02 E$ & 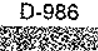 & Homblenda & 7559.20 & 95.77 & 3006.96500 & 0.05105 & 936.94360 & 0.28574 & 7503.37000 & 99.7 & 0.0086664 & $5.40 E-06$ & 1.0061 & 0.0013 & 4.3827 & $9.29 E-14$ & 5.2 & SPA0203-71 & $03 / 26 / 103$ \\
\hline $1454-01 \mathrm{~A}$ & $V-198$ & Homblenda & 221.39 & 2.91 & & & & & & & & & & & & & & & \\
\hline $1454-018$ & $V-198$ & Homblenda & 226.10 & 1.65 & $\begin{array}{l}15.450559 \\
16.25924\end{array}$ & $\begin{array}{l}0.01406 \\
0.01765\end{array}$ & 0.14291 & 0.00134 & 15.06572 & 97.5 & 0.0086664 & $5.40 \mathrm{E}-06$ & 1.0052 & .0012 & 0.1518 & $2.89 \mathrm{E}-15$ & 0.6 & SPA0203-71 & $3 / 21 / 03$ \\
\hline $1454-01 \mathrm{C}$ & V-198 & Hombienda & 334.12 & 1.75 & 24 & & 0.54587 & 0.00305 & 15.40669 & 94.7 & 0.0086664 & $5.40 \mathrm{E}-06$ & 1.0052 & .0012 & 0.3249 & $6.17 E-\{5$ & 1.0 & SPA0203-71 & $03 / 21 / 03$ \\
\hline $1454-010$ & $V-198$ & Homblenda & 340.37 & 1.49 & 24.16367 & $\begin{array}{l}0.01683 \\
0.01519\end{array}$ & 0.59534 & 0.00224 & 23.47687 & 97.4 & 0.0086664 & 5.40 & 1.0052 & 0.0012 & 0.4771 & $9.11 E-15$ & 1.5 & SPA0203-71 & $03 / 21 / 03$ \\
\hline $1454-191 E$ & V-198 & mblenda & 486.97 & 1.47 & 35.71152 & $\begin{array}{l}0.01519 \\
0.01345\end{array}$ & $\begin{array}{l}0.49885 \\
0.86777\end{array}$ & 0.00085 & 23.95905 & 99.1 & 0.0086664 & $5.40 \mathrm{E} \cdot 06$ & 1.0052 & 0.0012 & 0.8753 & $1.68 E-14$ & 2.1 & SPAO2 & $03 / 24103$ \\
\hline $1454-01 F$ & V-198 & omblenda & 647.89 & 1.43 & 49.90958 & 0.02119 & $\begin{array}{l}0.86777 \\
133330\end{array}$ & 0.00016 & 35.75500 & 100.1 & 0.0086664 & $5.40 E-06$ & 1.0052 & 0.0012 & 2.2188 & $4.21 E-14$ & 2.7 & 71 & $3 / 21 / 03$ \\
\hline $1454-01 \mathrm{G}$ & $V-\$ 98$ & Homblenda & 765.22 & 1.37 & 60 & 0.02591 & $\begin{array}{l}1.33330 \\
1.76413\end{array}$ & 0.00068 & 49.85660 & 39.8 & 0.0086664 & $5.40 \mathrm{E}-06$ & 1.0052 & 0.0012 & 6.7982 & $1.29 E-13$ & 3.4 & SPAC & $03 / 21 / 03$ \\
\hline $1454-01 \mathrm{H}$ & V.198 & Homblenda & 719.75 & 1.57 & 56.58355 & 0.02327 & $\begin{array}{l}1.76413 \\
1.40192\end{array}$ & 0.00063 & 60.96096 & 99.9 & 0.0086664 & $5.40 \mathrm{E}-06$ & 1.0052 & 0.0012 & 16.7315 & 3.18 & 4.2 & SPA0203-71 & $03 / 21 / 03$ \\
\hline $1454-011$ & $\vee-198$ & omblenda & 597.29 & 1.22 & 45.32159 & 0.02069 & $\begin{array}{l}1.40192 \\
1.06661\end{array}$ & 0.00053 & 56.57095 & 99.9 & .0086664 & 5.40E-06 & 1.0052 & 0.0012 & 22.9078 & $4.38 \mathrm{E}-13$ & 5.2 & & $03 / 21 / 03$ \\
\hline & & & & & & & & 0.00051 & 45.28593 & 99.9 & 0.0086664 & $5.40 \mathrm{E}-06$ & 1.0052 & 0.0012 & 2.9699 & $5.65 E-14$ & 5.2 & SPA0203.71 & $03 / 21 / 03$ \\
\hline $1454-02 \mathrm{~A}$ & V-198 & & 368.57 & ( & & $81>>$ & 0.26899 & 0.00022 & 26.154 & 99.8 & 34 & & $16 \mathrm{f}+2$ & & & & & & \\
\hline 1454.028 & V-198 & da & 706 & 1.0 & & 0.02348 & 1.43409 & 0.00044 & 55.28569 & 100.0 & 0086664 & & & & 2.3195 & & 1.5 & & \\
\hline $1454-02 \mathrm{C}$ & $V-198$ & da & 725.41 & 1.3 & 08 & 0.02393 & 1.49114 & 0.00031 & & 100.1 & $008 \hat{0} 64$ & 5.40 & 1.0060 & 0.0010 & 8.4162 & 1. $60 \mathrm{E}-13$ & 2.2 & & \\
\hline $1454-020$ & V-\$98 & & 571.80 & 1.5 & 43.22116 & 0.02235 & 1.11073 & 0.00105 & & & 0086664 & 5.40 & 1.0060 & 0.0010 & 11.5386 & & 3.0 & & $4 / 03$ \\
\hline $1454-02 \mathrm{E}$ & $V-198$ & mblenda & 577.69 & 1.67 & 43.32 & 88 & 0.76131 & -0.00047 & 43.0 & 99.5 & 0.008666 & 5.40 & 1.0060 & 0.0010 & 1.8916 & & 3.6 & 71 & $03 / 24 / 03$ \\
\hline $1454-02 \mathrm{~F}$ & $\checkmark-198$ & mblenda & 639.43 & 7.59 & & 20880 & 0.00000 & $\begin{array}{l}-0.00048 \\
-0.01173\end{array}$ & $\begin{array}{l}43.54977 \\
4908339\end{array}$ & 100.5 & 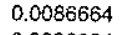 & 5.40 & 1.0060 & 0.0010 & $\$ .1380$ & 2.16 & 4.2 & SPA0203-71 & $03 / 24 / 03$ \\
\hline $1454-02 \mathrm{G}$ & $V-198$ & Homblenda & 671,61 & 1.40 & 51.62327 & 0.02183 & 1.72325 & $\begin{array}{l}-0.071 / 3 \\
-0.00076\end{array}$ & $\begin{array}{l}49.08339 \\
52.04367\end{array}$ & 107.6 & 64 & $5.40 E-06$ & 1.0060 & 0.0010 & 0.1482 & 2.84 & 4.8 & SPA0203-71 & $03 / 24 / 03$ \\
\hline & & 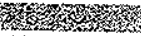 & & & & & & & 52,04367 & 100.7 & 0.0086664 & $5.40 \mathrm{E}-06$ & 1.0060 & 0.0010 & 2.4805 & $4.75 E-14$ & 5.2 & 3.71 & $03 / 24 / 03$ \\
\hline $1457-$ & A.746 & Homblenda & 70.84 & 3.94 & 10.44447 & 22 & 9.78039 & 0.02244 & 4.62 & & & & & & & & & & \\
\hline $1457-018$ & A. 746 & mblenda & 20.53 & 2.70 & & 83 & 10.57479 & 0934 & 1.32 & 40.6 & $\begin{array}{l}0.0086664 \\
0.0086664\end{array}$ & $\begin{array}{l}5.44 \\
5.40\end{array}$ & & 0.0012 & 10612 & $1.16 \mathrm{E}-15$ & 0.6 & SPA0203-71 & 103 \\
\hline $1457-01 \mathrm{C}$ & A. 746 & nblenda & 34.20 & 2.1 & 1. & 1572 & 2.29368 & 37 & 2.20 & 115.3 & & & 1.0052 & 0.0012 & 0.0 & & 1.0 & SPA0203-71 & $1 / 03$ \\
\hline $1457-010$ & A-748 & & 39 & 0 & & 2 & 3.70058 & 100 & 2.55 & & & 5.40 & 1.0 & 0.0 & 0. & & 1.5 & & \\
\hline 1457.01E & A-746 & & 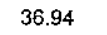 & & 2. & 1991 & 3.36 & 18 & & to & 0.0086664 & 5.40 & 1.0 & 12 & 11 & & & & $03 / 21 / 03$ \\
\hline$\$ 457$ & A-746 & la & & 2. & 2.24229 & 1835 & 2.95 & & 2.3 & 110.0 & 664 & 5.40 & 1.0052 & 0.0012 & & & 2 & $3-71$ & $03 / 21 / 03$ \\
\hline $1457-016$ & A-748 & a & 69.58 & 4.05 & 3. & & 24 & & & 103.4 & & & & 0.0012 & & & 3.4 & 71 & $03 / 21 / 03$ \\
\hline \$457-01H & A-746 & nblenda & 44.34 & 2.72 & & & & & & & & & 1.0 & 0.0 & & & 4.2 & 71 & \\
\hline $1457-011$ & A-746 & Homblenda & 42.90 & 2.52 & 2.41347 & 0.02273 & & $\begin{array}{l}-0.00023 \\
-0.00001\end{array}$ & 年, & $\begin{array}{l}119.7 \\
114.8\end{array}$ & 0.06 & 5.4 & 1.0 & 0.0 & & & 5.2 & SPA & 03) \\
\hline & & & & & & & 83002 & -0.00001 & 2.77708 & 114.8 & 0.0086664 & $5.40 E-06$ & 1.0052 & 0.0012 & 0.0253 & $4.86 \mathrm{E}-16$ & 5.2 & SPA0203.71 & $03 / 21 / 03$ \\
\hline 1457-02A & & & & & & & & & & & & & & & & & & & \\
\hline$\{457.02 B$ & $A-746$ & da & 21.61 & 1.26 & & & & 3319 & & & & & & 0.00 & 0.0 & & 1.0 & & \\
\hline & & & & & & & & 83 & 23. & 66.7 & 0.00 & & & & 65 & -16 & 1.6 & & $3 / 24 / 03$ \\
\hline $1457-02 \mathrm{D}$ & A. 746 & at & & 0.53 & 2.47923 & & 232 & & 2.3 & 81.0 & & & 1.0060 & 0.0010 & 0.1117 & & 2.0 & & $4 / 03$ \\
\hline 1457 & A.746 & Homblenda & 31.38 & 0.77 & 2.50646 & 0.02 & 3.50991 & & $\begin{array}{l}2.36669 \\
2.02471\end{array}$ & 95.3 & & $5.40 \mathrm{E}-06$ & 1.0060 & 0.0010 & 0.15 & & 3.0 & & $03 / 24 / 03$ \\
\hline & & & & & & (a) & & 0.00259 & 2.02471 & 80.6 & 0.00866 & $5.40 E-06$ & 1.0060 & 0.0010 & 0.0878 & $1.66 \mathrm{E}-15$ & 5.2 & SPAO203.71 & $03 / 24 / 03$ \\
\hline $1461-01 A$ & 82 & $\mathrm{Bi}$ & $80-2$ & 4.69 & 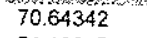 & 0. & 0.76523 & 43 & 65.29 & 9 & & & & & & & & & \\
\hline 018 & & & & & & & & & & & & & & & & & $0.5>-5$ & & \\
\hline & & & & 1. & 7 & 0.0 & & & & 99.8 & & & & & & & & & $03 / 22 / 03$ \\
\hline & & & & 1. & & & & & 4 & 99.8 & & & & & & & 1.3 & .71 & \\
\hline$\{461.0\} E$ & & Bio & & 1. & & & & 1 & 49 & 99.7 & & & & & & & 1.7 & 71 & \\
\hline $1461.01 F$ & 32 & Biot & & & & & & & & & & & & & 4.3903 & -14 & 2.4 & & \\
\hline & $0-98$ & & & & & & & & & & & & 1.0052 & 0.0012 & 8.6366 & & 3.2 & & \\
\hline & .982 & Biotita & 831.45 & 2.62 & 68.00439 & 01381 & 08 & 0159 & 67.55438 & $\begin{array}{l}99.9 \\
99.3\end{array}$ & & 10E-06 & $\begin{array}{l}1.0052 \\
1.0052\end{array}$ & $\begin{array}{l}0.0012 \\
0.0012\end{array}$ & & & 4.2 & & \\
\hline & & & & & & & & & & & 0086664 & 10E-06 & .0052 & 0.0012 & 1.9832 & $3.79 E-14$ & 5.2 & PA0203-71 & $03 / 22 / 03$ \\
\hline
\end{tabular}




\begin{tabular}{|c|c|c|c|c|c|c|c|c|c|c|c|c|c|c|c|c|c|c|c|}
\hline Run IO\# & Sample & Materiat & $\begin{array}{l}\text { Age } \\
\text { (Ma) }\end{array}$ & $\stackrel{ \pm}{ \pm}$ & $40 / 39$ & 38139 & $37 / 39$ & $36 / 39$ & $40^{*} ; 39$ & $\% \operatorname{Rad}$ & $J$ & \pm & Discr. & \pm & $\begin{array}{l}\text { Ar40 } \\
(n A)\end{array}$ & $\begin{array}{l}\text { Ar40 } \\
\text { (mois) }\end{array}$ & $\begin{array}{l}\text { Laser } \\
\text { (W) }\end{array}$ & Irrad. & Run Date \\
\hline $1461-02 \mathrm{~A}$ & D.982 & Biolita & 852.24 & 2.62 & 71.46517 & 0.01402 & 0.00000 & 0.00606 & 67525 & 97.5 & 0. & 5 & 7.0069 & 0.0013 & 2 & 4 & 0.6 & 8 & 33 \\
\hline 1461.028 & 0.982 & Biolita & 5.41 & 1.88 & 72.27958 & 0.01359 & 0.00000 & 0.00072 & .06786 & 99.7 & 0. & $5.40 E-06$ & 1.0061 & 0.0013 & 8.8022 & $1.68 \mathrm{E}-13$ & 0.9 & A0203-71 & $125 / 03$ \\
\hline $1461-02 \mathrm{C}$ & D-982 & Biolita & 80 & 1.58 & 71.30505 & .01310 & 0.00000 & 0.00044 & 71.17499 & 99.8 & 0.0086664 & $5.40 \mathrm{E}-06$ & 1.0061 & 0.0013 & 7.4202 & 1.40 & 1.3 & PA0203-71 & $3 / 25 / 03$ \\
\hline $1461-02 D$ & D-982 & Biotita & 47.69 & 1.58 & 9.18083 & .01251 & 0.00000 & -0.00010 & 69.20904 & 100.0 & 0.0086664 & $5.40 E-06$ & 1.0061 & 0.0013 & 5.4678 & 1.04 & 2.0 & SPA0203-71 & $03 / 25 / 03$ \\
\hline 1461-02E & D-982 & Biotita & 2.05 & 1.58 & .67311 & 0.01031 & 0.00000 & 0.00019 & 67.61606 & 99.9 & 0.0086664 & $5.40 E-06$ & 1.0061 & 0.0013 & 5.2357 & $9.94 E-14$ & 2.8 & SPA0203-71 & $03 / 25 / 03$ \\
\hline $1461-02 \mathrm{~F}$ & D-982 & Biotita & 4.28 & 1.81 & .97661 & 0.01242 & 0.00000 & 0.00031 & 69.88423 & 99.9 & 0.0086664 & $5.40 E-06$ & 1.0061 & 0.0013 & 6.2997 & $1.19 E-13$ & 3.5 & SPA0203-71 & $3 / 25 / 03$ \\
\hline $1461-02 G$ & $0-982$ & Biotita & 9.87 & 1.30 & 70.49345 & 1.01338 & 0.00000 & 0.00011 & 70.45928 & 100.0 & 0.0086664 & $5.40 E-06$ & 1.0061 & 0.0013 & 6.8593 & 13 & 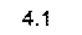 & $\mathrm{AAO} 203-71$ & $3 / 25 / 03$ \\
\hline $1461-02 \mathrm{H}$ & D-982 & Biotita & 851.82 & 1.88 & 69.60797 & 0.01335 & 0.00000 & -0.00008 & 69.63209 & 100.0 & 0.0086664 & $5.40 \mathrm{E}-06$ & 1.0061 & 0.0013 & 3.9141 & $7.42 E-14$ & 5.2 & PA0203-71 & $3 / 25 / 03$ \\
\hline 1070 & & & & & & & & & & & & & & & & & & & \\
\hline$\{475-0\} A$ & C-299 & Biotita & 829.40 & 8.37 & 73.58474 & 0.00503 & 0.00000 & 0.00708 & 71.48992 & 97.2 & 0.0081642 & $4.20 \mathrm{E}-06$ & 1.0060 & 0.0010 & 0.2853 & $5.44 \mathrm{E}-15$ & 0.5 & SPA0203-72 & $3 / 23 / 03$ \\
\hline $1475.01 B$ & C-299 & Biotita & 974.70 & 1.81 & 88.15942 & 0.01182 & 0.00000 & 0.00135 & 87.75874 & 99.5 & 0.0081642 & $4.20 E-06$ & 1.0060 & 0.0010 & 2.8795 & $5.48 \mathrm{E}-14$ & 0.9 & SPAO203-72 & $3 / 23 / 03$ \\
\hline $1475.01 C$ & C. 299 & Biotita & 979.68 & 1.77 & 3.77449 & 0.01159 & 0.00000 & 0.00147 & 88.34021 & 99.5 & 0.0081642 & $4.20 E-06$ & 1.0060 & 0.0010 & 5.4518 & & & 3.72 & $3 / 23 / 03$ \\
\hline 1475-01D & C-299 & Biotita & 982.1 & 1.8 & .85047 & 0.01257 & 0.00000 & 00074 & 88.63247 & 99.8 & 0.0081642 & $4.20 \mathrm{E}-06$ & 1.0060 & 0.0010 & 7.2337 & 1.38 & 1.7 & SPA0203-72 & $3 / 23603$ \\
\hline 1475-01E & C. 299 & Biotita & 979.72 & $2.5 \mathrm{~S}$ & 47370 & 0.01237 & 0.00352 & 0.00044 & 88.34492 & 99.9 & 0.0081642 & 4.20E-06 & 1.0060 & 0.0010 & 10.3071 & 1.97 & 2.4 & SPA0203-72 & $3 / 23103$ \\
\hline $1475-01 \mathrm{~F}$ & C-299 & Biotita & 978.73 & 1.54 & 88.25731 & 0.01236 & 0.00000 & 0.00009 & 88.22948 & 100.0 & 0.0081642 & $4.20 \mathrm{E}-06$ & 1.0060 & 0.0010 & 12.9641 & 13 & 3.2 & SPA0203-72 & $3 / 23 / 03$ \\
\hline $1475-016$ & C-299 & Biotita & 982.00 & 1.60 & 3.65022 & 01159 & 0.00000 & 0.000 & 88.61115 & 100.0 & 0.0081642 & $4.20 \mathrm{E}-06$ & 1.0060 & 0.0010 & 12.0054 & & 4.2 & SPA0203-72 & $3 / 23 / 03$ \\
\hline 1475-0tH & $C-299$ & Biotita & 984.23 & 1.77 & 88.99377 & .01282 & 0.03729 & 0.00043 & 88.87189 & 99.9 & 0.0081642 & 4.20E-06 & 1.0060 & 0.0010 & 11.8117 & $26 \mathrm{E}-13$ & 5.2 & SPA0203-72 & $3 / 23 / 03$ \\
\hline $1475-02 A$ & 290 & Biotita & 8165 & 2.53 & 75.18341 & 1713 & 0. & 7 & 11 & 93.2 & 0.0081642 & 0.06 & 1.0061 & 13 & 1.1357 & & 0.7 & 72 & $25 / 03$ \\
\hline $1475-02 B$ & C-299 & Biotita & 953.79 & 1.86 & 85.56384 & 1234 & 0.00 & & & 99. & & & & & & & & & \\
\hline $1475-02 \mathrm{C}$ & C-299 & Biolita & 97164 & 15 & 87.43825 & 7 & 0.00 & 0.000 & 87.40 & 100.0 & 0.0081642 & $4.20 \mathrm{E}-06$ & 1.0061 & 0.0013 & 11.6692 & 2.22 & 1.6 & 72 & 103 \\
\hline $1475-02 D$ & $\mathrm{C}-2$ & Biotita & 972.91 & 1.78 & 87.68353 & 0.01304 & 0.00000 & 0.00045 & 87.55023 & 99.8 & 0.0081642 & $4.20 E-06$ & 1.0061 & 0.0013 & 13.7798 & 2.62 & 2.3 & SPA0203-72 & $3 / 25 / 03$ \\
\hline $1475-02 E$ & C.299 & Biotita & 980.98 & 2.70 & 88.54527 & 0.01152 & 0.00000 & 0.00018 & 88.49209 & 99.9 & 0.0081642 & $4.20 \mathrm{E}-06$ & 1.0061 & 0.0013 & 12.3728 & 2.35 & 3.0 & SPA0203-72 & $3 / 25 / 03$ \\
\hline $1475-02 \mathrm{~F}$ & C- 299 & Biotita & 981.50 & 3.31 & 88.66035 & 0.01124 & 0.02433 & 00037 & 88.55314 & 99.9 & 0.0081642 & 4.20E-06 & 1.0061 & 0.0013 & 15.9679 & & & $03-72$ & $3 / 25 / 03$ \\
\hline 1475.026 & C-299 & Biotita & 976.81 & 1.85 & 3.03749 & 001185 & 0.00 & & & 100.0 & 42 & 06 & 1.0061 & 0.0013 & 4.9 & & & & 103 \\
\hline $1475.02 \mathrm{H}$ & C-299 & Biotita & 979.86 & 1.99 & 88.33758 & 0.01073 & 0.06000 & .0 .00008 & 88.361 & 100.0 & 0.0081642 & $4.20 E \cdot 06$ & 1.0061 & 0.0013 & 6.2235 & $1.18 E-13$ & & SPA0203-72 & $3 / 25 / 03$ \\
\hline & C-299 & Homblenda & 6064.0 & 170.13 & & & & & & & & & & & & & & & \\
\hline $\begin{array}{l}1481-01 \mathrm{~A} \\
1481-01 \mathrm{~B}\end{array}$ & $\begin{array}{l}\mathrm{C}-299 \\
\mathrm{C}-299\end{array}$ & $\begin{array}{l}\text { Hombienda } \\
\text { Homblenda }\end{array}$ & & 170.13 & 3444.26700 & -0.12433 & 0.00000 & 12107 & 3408.46500 & 99.0 & & -06 & 0060 & 0.00 & & & & & \\
\hline $1481-01$ & $\begin{array}{l}\text { C-299 } \\
\text { C-299 }\end{array}$ & nblenda & 81.38 & 57.34 & 88.99680 & -0.01638 & 0.00000 & & & 97 & & & & & & & & & \\
\hline 1481 & $\begin{array}{l}C-299 \\
c-299\end{array}$ & & & 26. & & & & & & 10 & & & & 10 & & & & & \\
\hline $1481-010$ & $\begin{array}{l}C-299 \\
C-299\end{array}$ & & & & & 0. & 2.6 & 0.00 & 126.27070 & 99.4 & 1642 & 06 & 1.0060 & 0.0010 & 4.1541 & & 2. & 3.72 & 3/23/03 \\
\hline 1481. & C-299 & & & & 93 & 0.01641 & 3.22961 & 43 & 444 & 99.8 & 1642 & & 1.0060 & 0.0010 & 16.9203 & & & 3.72 & $3 / 23 / 03$ \\
\hline $1481-01 F$ & C-299 & & M & 1.8 & 88 & 4466 & & & 644 & 99.9 & & & 1.0060 & 0.0 & 10.2208 & & & & $3 / 03$ \\
\hline $1481.01 G$ & C. 299 & & 66 & 3.9 & 3 & 0.01512 & & & & 99. & & & & & & & & & $33 / 23 / 03$ \\
\hline $1481.01 \mathrm{H}$ & C-299 & Homblenda & 1015.44 & 3.95 & 92.62009 & 0.01626 & 3.48667 & 0.00184 & 92.56082 & 99.7 & 0.0081642 & $4.20 \mathrm{E}-06$ & 1.0060 & 0.0010 & 1.5192 & $2.89 E-14$ & 0.2 & SPA0203.72 & $3 / 23 / 03$ \\
\hline & & & & & & & & & & & & & & & & & & & \\
\hline 1481. & C. & & & 2 & & & & & & 9 & & & & & & & & & \\
\hline $1481-02 \mathrm{C}$ & c. & & & 1. & & 0 & & & & 99 & & & & & & & & & \\
\hline $1481-020$ & c. 29 & & & 1. & & H & & & & 100.0 & & & & & & & & & 503 \\
\hline $1481.02 \mathrm{E}$ & C-299 & & & 3.1 & & 0. & & & & 99 & & & 1.0 & & & & & & 5103 \\
\hline $1481-02 \mathrm{~F}$ & C.-299 & & 989.0 & 3.78 & 89.6 & 0.01725 & 3.6 & 0. & 89. & 99. & 0. & 4.2 & 10 & 0.0 & 1.9810 & 3. & & & $03 / 25 / 03$ \\
\hline 107 & & & & & & & & & & & & & & & & & & & \\
\hline 147 & $c-3$ & & 1 & & & & & & & & & & & & & & & & \\
\hline & & & 4 & 17. & & & & & & & & & & & & & & & \\
\hline $1477-C$ & C. 32 & & & & & & & & & 10 & & & & & & & & & \\
\hline & & & & & & & & & & & & & & & & & & & \\
\hline & & & & & & & & & & 10 & & & & & & & & & \\
\hline & & & & 1. & & & & & & 100 & & & & 0.0 & 15.5521 & & & & \\
\hline $1477.01 G$ & C-32 & & 981.64 & 1.8 & & & & & & 104 & & & & & & & & & \\
\hline 1477.0 & C-32 & Homblenda & 30.85 & 2.23 & 88.26823 & 01862 & 1.42895 & .0 .00004 & $88.47 \hat{0} 58$ & 100 & 0.0081642 & $4.20 E-06$ & 1.0060 & 0.0010 & 3.8514 & $.33 E-14$ & 5.2 & SPA0203-72 & $03 / 23 / 03$ \\
\hline & & & & & & & & & & & & & & & & & & & \\
\hline & & & & 6.9 & & & 2.15 & & 98.2786 & 99 & & & & & & & & & \\
\hline $1477-0$ & C. 32 & & & 1.7 & & & & & & & & & & & & & & & \\
\hline & C-32 & & & & & & & & & & & & & & & & 2. & & \\
\hline & & & & & & & & & & 99 & $\{642$ & $4.20 \mathrm{E}-08$ & 1.0061 & 0.0013 & & & 3. 2 . & & $03 / 25 / 03$ \\
\hline & & & & 1.87 & & 0.02228 & 2911 & 128 & & 99.8 & 642 & & & & & & & & \\
\hline $1477.02 \mathrm{G}$ & C.32 & Homblenda & 982.52 & 2.75 & 88.77186 & 0.02596 & 6794 & 0254 & 256 & 99.6 & & & 0061 & & & & & & \\
\hline
\end{tabular}




\begin{tabular}{|c|c|c|c|c|c|c|c|c|c|c|c|c|c|c|c|c|c|c|c|}
\hline & & & sos & (n) & & & & & & & & & & & (is) & 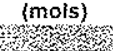 & (w) & & \\
\hline $1479-01 \mathrm{~A}$ & C-32 & Biotita & 908.19 & 4.57 & 85.78201 & 0.01827 & 0.42725 & 0.01925 & 80.14929 & 93.4 & 0.0081642 & 36 & 10060 & 010 & 737 & $1.66 \mathrm{E}-14$ & 0.5 & 72 & 23103 \\
\hline 1479.018 & $\mathrm{C}-32$ & 8iotita & 934.62 & 1.63 & 83.28857 & 0.01347 & 0.31891 & 0.00180 & 82.79828 & 99.4 & 0.0081642 & $4.20 E-06$ & 1.0080 & 0.0010 & 5.1650 & $9.88 E-14$ & 0.9 & SPAO203-72 & $1 / 23 / 03$ \\
\hline $1479.01 C$ & & lita & 951.64 & 2.28 & 5.10181 & 0.01247 & 0.00000 & .00004 & 85.08820 & 100.0 & 0.0081642 & $4.20 E-06$ & 1.0060 & 0.0010 & 6.4470 & $1.70 \mathrm{E}-13$ & 1.3 & SPA0203-72 & $03 / 23 / 03$ \\
\hline 1479.010 & $\mathrm{C}-32$ & Biotita & 947.18 & 2.14 & 64298 & 0.01166 & 0.05008 & 0.00025 & 84.57663 & 99.9 & 0.0081642 & $4.20 \mathrm{E}-06$ & 1.0060 & 0.0010 & 7.6859 & $1.46 E-13$ & 1.8 & SPAO203-72 & $03 / 23 / 03$ \\
\hline $1479.01 \mathrm{E}$ & $\mathrm{C}-32$ & Biotita & 948.94 & 1.39 & 4.76431 & 0.01333 & 0.00000 & .0 .00005 & 84.77774 & 100.0 & 0.0081642 & $\begin{array}{l}4.20 E-06 \\
\text { - }\end{array}$ & 1.0060 & 0.0010 & 7.6252 & $1.45 \mathrm{E}-13$ & 2.3 & SPA0203-72 & $03 / 23 / 03$ \\
\hline $1479.01 \mathrm{~F}$ & $c-32$ & Biotita & 947.77 & 1.24 & 4.73512 & 0.01388 & 0.00000 & 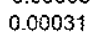 & 84.64435 & 99.9 & 0.0081642 & $4.20 E-06$ & 1.0060 & 0.0010 & 11.7756 & $2.23 E-13$ & 0 & AO203-72 & 0703 \\
\hline $1479-016$ & $C-32$ & Biotita & 945.72 & 2.34 & 84.36713 & 0.01192 & 0.00000 & -0.00014 & 84.40855 & 100.0 & 0.0081642 & $4.20 \mathrm{E}-06$ & 1.0060 & 0.0010 & 10.0600 & $1.80 \mathrm{E}-13$ & 4.0 & SPA0203-72 & $1 / 23 / 03$ \\
\hline $1479-01 \mathrm{H}$ & C.32 & Biotita & 923.27 & 2.06 & .42561 & 0.01191 & 0.00000 & -0.00144 & 81.84990 & 100.5 & 0.0081642 & $4.20 \mathrm{E}-06$ & 1.0060 & 0.0010 & 1.2722 & $2.42 \mathrm{E}-14$ & 5.2 & SPA0203-72 & $3 / 23 / 03$ \\
\hline $1479-02 \mathrm{~A}$ & C. 32 & Biotita & 0.04 & 6.80 & 82738 & 1850 & 1308 & 0.01717 & 75809 & 943 & 12 & 16 & 10064 & 3 & 57 & 14 & 0.6 & 72 & 3 \\
\hline $1479.02 B$ & $C-32$ & Biotita & 64.15 & 88 & 5.78925 & 0.01416 & 0.00000 & 00139 & 85.37791 & 99.5 & 0.0081642 & $4.20 \mathrm{E}-06$ & .0061 & 0.0013 & 4.3960 & & 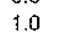 & 3.72 & $25 / 03$ \\
\hline $1479-02 \mathrm{C}$ & C. 32 & Biotita & 955.04 & 1. & 5.68750 & 0.01343 & 0.00964 & 00070 & 85.48018 & 99.8 & 0.0081642 & $4.20 \mathrm{E}-06$ & 1.0061 & 0.0013 & 5.6610 & 1.0 & 1.3 & SPAO203-72 & $25 / 03$ \\
\hline $1479-02 \mathrm{D}$ & $C-32$ & Biotita & 950.97 & 2. & 11483 & 0.01358 & 0.00000 & 0.00035 & 85.01176 & 99.9 & 0.0081642 & $4.20 \mathrm{E}-06$ & 1.0061 & 0.0013 & 7.6308 & $1.45 \mathrm{E}-13$ & 1.8 & SPAO203-72 & $3 / 25 / 03$ \\
\hline $1479.02 E$ & $C-32$ & Biotita & 957.81 & 2.05 & 85.72906 & 0.01332 & 0.00000 & .0 .00024 & 85.80026 & 100.1 & 0.0081642 & $4.20 E-06$ & 1.0061 & 0.0013 & 6.6842 & 1.27 & 2.3 & SPA0203.72 & $3 / 25 / 03$ \\
\hline$\$ 479.02 \mathrm{~F}$ & $\mathrm{C}-32$ & Biotita & 954.83 & 1.70 & 85.45393 & 0.01280 & 0.00000 & 0.00007 & 85.43260 & 100.0 & 0.0081642 & $\begin{array}{l}4.20 \mathrm{E}-06 \\
4.06\end{array}$ & 1.0061 & 0.0013 & $\begin{array}{l}0.0042 \\
7.3009\end{array}$ & 13 & 2.8 & PAO203-72 & $1 / 25 / 03$ \\
\hline $1479.02 G$ & C- 32 & Biotila & 959.14 & 2.20 & 5.95381 & 0.01207 & 0.00000 & 0.00000 & 85.95345 & 100.0 & 0.0081642 & $4.20 \mathrm{E}-06$ & 1.0061 & 0.0013 & 10.2438 & & 3.6 & $3-72$ & $25 / 03$ \\
\hline $1479-02 \mathrm{H}$ & 32 & Biotita & 952.39 & 1.4 & 85.16 & 0.01372 & 0.000 & -0.00005 & 85.17435 & 100.0 & 0.0081642 & $4.20 \mathrm{E}-06$ & 1.0061 & 0.0043 & 9.2898 & $1.76 E-13$ & 5.2 & SPAO203-72 & $3 / 25 / 03$ \\
\hline & & & & & & & & & & & & & & & & & & & \\
\hline $1443-01 \mathrm{~A}$ & $V-309$ & mblenda & 0.00 & $\{384.75$ & -2637.272 & 0.83163 & 24.07196 & 0.97685 & -2969.778 & 110.9 & 0.0086664 & $5.40 \mathrm{E}-06$ & 1.0064 & 0013 & 0.0614 & 1.16E-15 & 0.3 & 3.71 & 1102103 \\
\hline 1443-018 & $V-309$ & nomblenda & 8183.85 & 532.05 & 10916.270 & 0.51199 & 0.00000 & 0.88227 & 10655.590 & 97.6 & 0.0086664 & $5.40 \mathrm{E}-06$ & 1.0064 & 0013 & 0.9069 & & 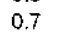 & & 1102103 \\
\hline $1443-01 \mathrm{C}$ & $V-309$ & homblenda & 7217.63 & 1008.82 & 6021.962 & -0.24069 & & -0. & 6189.197 & 102.6 & 6664 & 5.4 & 1.0064 & 0.0013 & & & 1.1 & $3-71$ & 102203 \\
\hline 1443.010 & $V-309$ & homblenda & 45.65 & 722.49 & 3 & -0.50441 & 0.00000 & .0 .40133 & 5942.602 & 102.0 & 0.0086664 & $5.40 \mathrm{E}-06$ & 1.0064 & 0.0013 & 0.3494 & & 1.5 & $3-71$ & $01 / 02 / 03$ \\
\hline 1443-01E & $V-309$ & & 26.78 & 221.93 & 3572 & 0.18094 & 0.48528 & 0.16537 & 3524.848 & 98.6 & 0.0086664 & $5.40 \mathrm{E}-06$ & 1.0064 & 0.0013 & 0.7845 & 1.4 & 1.9 & SPAD203-71 & $01 / 02 / 03$ \\
\hline $1443-01 \mathrm{~F}$ & $V-309$ & blenda & 4.87 & 156.93 & 2063.927 & -0.05546 & 0.00000 & -0.01496 & 2068.341 & 100.2 & 6664 & $5.40 \mathrm{E}-06$ & 1.0064 & .0013 & 0.5795 & & 2.5 & $03-71$ & $1 / 0203$ \\
\hline $1443-01 G$ & $V-309$ & homblenda & $\{4.69$ & 78.18 & 399.25130 & -0.02703 & 0.00000 & -0.01679 & 404.20870 & 101.2 & 6664 & & 1.0064 & 3 & & & 3.2 & & 3 \\
\hline $1443-01 \mathrm{H}$ & V-309 & homblenda & 6.73 & 3.34 & & 0.01559 & 0.08224 & 0.00133 & 97.31231 & 99.6 & 0.0086664 & $5.40 E-06$ & 1.0064 & 0.0013 & 1.6965 & & 4.3 & $03-71$ & 1102103 \\
\hline $1443-011$ & V.309 & homblenda & 85.67 & 1.59 & 84.17215 & 0.01708 & 0.01251 & 0.00099 & 83.88181 & 99.7 & 0.0086664 & $5.40 \mathrm{E}-06$ & 1.0064 & 0.0013 & 39.2667 & $7.48 E-13$ & 5.2 & PA0203-71 & $1102 / 03$ \\
\hline 1443 & 309 & & & 24 & & & & & & & & & & & & & & & \\
\hline $1443-028$ & $V-309$ & da & 31 & 102.71 & 50 & & & & & 96.8 & 664 & & 10050 & 0.0014 & & & 3.0 & $03-71$ & $1 / 23 / 03$ \\
\hline $1443.02 C$ & V-308 & & 22.30 & 7.86 & & 0.01333 & 00000 & .0 .00750 & 97. & 102.3 & 664 & $5.40 \mathrm{E}-06$ & 1.0050 & 0.0014 & 16 & & 4.3 & $203-73$ & $1 / 24 / 03$ \\
\hline $1443-020$ & $V-309$ & homblenda & 1095.46 & 6. & 65070 & 1804 & 3790 & 0.00092 & 440 & 99.7 & 664 & $5.40 \mathrm{E}-06$ & 1.0050 & 0.0014 & & & 4.5 & 03-71 & $1 / 24 / 03$ \\
\hline $1443-02 E$ & $V-309$ & $d a$ & 8.71 & 3. & 44 & 01516 & 900 & -0.00082 & & 100.3 & & & 1.0050 & 0.0014 & & & 4.7 & & \\
\hline $1443-02 F$ & $V-309$ & nda & 978.13 & 4.5 & & 0.01926 & & & & 98.9 & 664 & $5.40 \mathrm{E}-06$ & 1.0050 & 0.0014 & 0.8 & & $\begin{array}{l}4.1 \\
4.9\end{array}$ & $3-71$ & 124103 \\
\hline $1443-02 G$ & -309 & homblenda & 981.37 & 1.67 & 83.65100 & 0.01711 & 0.00000 & 0.00083 & 83.40684 & 99.7 & 0.0086664 & $5.40 \mathrm{E}-06$ & 1.0050 & 0.0014 & 15.9881 & $3.04 E-13$ & 5.2 & SPA0203-71 & 124103 \\
\hline & & & & 34. & & & & & & & & & & & & & & & \\
\hline 38 & $V-309$ & & 97 & 1.7 & & 0. & & & & & & & & 0.0014 & & & 3. & & $124 / 03$ \\
\hline $1443-03 \mathrm{C}$ & $V \cdot 309$ & & & 1.8 & & 0.0 & & & & 99 & & 5.4 & 1.0050 & 0.0014 & 17. & & 4. & 3.71 & $124 / 03$ \\
\hline $1443-030$ & $V-309$ & & & 3.5 & & 0.013 & & .0 .0 & & 100.1 & & & 1.0 & 0.0014 & & & 4. & $3-71$ & 24103 \\
\hline & $V-309$ & & & & & & & & & 101 & & & 1.0 & 0. & & & & & 3 \\
\hline $1443-03 F$ & $V-309$ & & 30 & 15 & & & & & 84. & 100.9 & 664 & 5.4 & 1.0 & 0.0014 & & & 4. & & \\
\hline $1443-03 \mathrm{G}$ & $V-309$ & & & 33.27 & 79.98 & 0. & 2.66639 & 0.00535 & & 98.3 & & & 1.0 & 0.0014 & & & 4. & $3-71$ & $01 / 24 / 03$ \\
\hline $1443-03 \mathrm{H}$ & $V-309$ & & 996.83 & 53.11 & 85.32 & 0.05456 & 0.00000 & 0.00071 & & 99. & & & 1.0 & 0.0 & & & 5. & & $01 / 24 / 03$ \\
\hline $1443-031$ & $v-309$ & homblenda & 973.86 & 3.1 & 83.54 & 0.01 & 0.15315 & 0.00148 & 83.1 & 99.5 & 4 & .06 & 1.0050 & 0.0 & 1.8 & 3.1 & 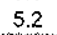 & $A 0203-71$ & $124 / 03$ \\
\hline & & & & & & & & & & & & & & & & & & & \\
\hline $144401 \mathrm{~A}$ & $V-309$ & & 621.6 & 46.41 & 48.80 & . & s. & 0.004 & 47 & 37. & & & 1.0 & & & & & & \\
\hline & & & & 10.3 & 8 & 0 & & & & & & & & 0.00 & & & & & 3 \\
\hline $1444-01 \mathrm{C}$ & $v-3$ & & & & & & & & & & & & & & & & 0. & & 3 \\
\hline & $V-3 C$ & & & & & & & & & & & & & & & & 1 & 71 & $102 / 03$ \\
\hline & & & & & & & & & 81 & 100.1 & & 5.40 & 1.0064 & 0.0 & & & 1. & & \\
\hline & & & & 2.63 & & 0.012 & & & 814 & 99 & & & 10 & 0 & & & $i$ & & \\
\hline & & & & 1.73 & & & & & & 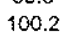 & & & & & & & 2. & & \\
\hline $01 \mathrm{H}$ & 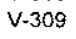 & & & & & & & & & & & & & & & & 3. & $03-71$ & 3 \\
\hline & v. & & & & & & & & & 100.3 & & $5.4 \mathrm{C}$ & 1.0064 & 3 & 1.3 & & 4. & & \\
\hline 14 & & & & 1.86 & & 01261 & & .0 .00007 & .50046 & 100.0 & & & 1.0 & & & & & & \\
\hline $1444.01 K$ & V-309 & biotita & 962.93 & 2.44 & 81.30742 & $0.0122\}$ & 0.01865 & 0.00026 & 81.38539 & 100.1 & 0.0086664 & $5.40 \mathrm{E}-06$ & 1.0064 & 0.0013 & 4.5784 & 3.78 & 5.2 & A0203-71 & 102103 \\
\hline $144 \cdot c-6$ & & & & & & 1903 & 3868 & 0.01015 & 97408 & 3.3 & 64 & $=06$ & & & & $5.05 E-15$ & & $3-7$ & \\
\hline
\end{tabular}




\begin{tabular}{|c|c|c|c|c|c|c|c|c|c|c|c|c|c|c|c|c|c|c|c|}
\hline Run ID\# & Sample & Material & $\begin{array}{l}\text { Age } \\
\text { (Ma) }\end{array}$ & $\begin{array}{c} \pm \\
(\mathrm{Ma})\end{array}$ & $40 / 39$ & $38 i 39$ & $37 / 39$ & $35 / 39$ & $40^{*} / 39$ & $\%$ Rad & $\mathrm{J}$ & \pm & Discr. & \pm & $\begin{array}{l}\text { Ar40 } \\
\text { (nA) }\end{array}$ & $\begin{array}{l}\text { Ar40 } \\
\text { (mols) }\end{array}$ & $\begin{array}{l}\text { Laser } \\
\text { (W) }\end{array}$ & Is & $\mathrm{R}$ \\
\hline $\begin{array}{l}1444-02 B \\
1444.02 C\end{array}$ & V-309 & biotita & 967.49 & 3.32 & 82.42479 & 0.01055 & 0.00000 & 0.00183 & 81.88325 & 99.3 & 0.0086664 & $5.40 \mathrm{E}-06$ & 1.005 & 4 & 1.2225 & $2.32 \mathrm{E}-14$ & 1.4 & A0203-7\} & $01 / 24103$ \\
\hline $\begin{array}{l}3444-02 C \\
1444-02 D\end{array}$ & $\begin{array}{r}V-309 \\
V 300\end{array}$ & biotita & 969.52 & 2.57 & $\begin{array}{l}82.3015 ! \\
885054\end{array}$ & 0.01301 & 0.00000 & 0.00066 & 82.10552 & 99.8 & 0.0086864 & $5.40 E-06$ & 1.0050 & 0.0014 & 2.5226 & 4.80 & 1.9 & -71 & $01 / 24 / 03$ \\
\hline $\begin{array}{l}1444-02 D \\
1444-02 E\end{array}$ & $\begin{array}{l}\text { V.309 } \\
V-309\end{array}$ & $\begin{array}{l}\text { biotita } \\
\text { biolita }\end{array}$ & $\begin{array}{l}974.57 \\
974.34\end{array}$ & $\begin{array}{l}2.21 \\
1.77\end{array}$ & $\begin{array}{l}82.56054 \\
82.57990\end{array}$ & 0.01203 & 0.00000 & -0.00 & 82.65942 & 100.1 & 0.0086664 & $5.40 \mathrm{E}-06$ & 1.0050 & 0.0014 & 3.3358 & $6.37 E-14$ & 2.4 & SPA0203-71 & $01 / 24 / 03$ \\
\hline $\begin{array}{l}1444-02 E \\
1444-02 F\end{array}$ & $\begin{array}{l}\text { V-309 } \\
\text { V-309 }\end{array}$ & $\begin{array}{l}\text { biolita } \\
\text { biotita }\end{array}$ & $\begin{array}{l}9 / 4.34 \\
976.18\end{array}$ & 346 & 82.57990 & 0.01236 & 0.00000 & -0.00078 & 82.63364 & 100.1 & 0.0086864 & $5.40 E-06$ & 1.0050 & 0.0014 & 6.1104 & $1.17 \mathrm{E}-13$ & 3.1 & SPAO203-71 & $01 / 24 / 03$ \\
\hline $\begin{array}{l}14444.02 \mathrm{~F} \\
144-022 \mathrm{G}\end{array}$ & $\begin{array}{l}V-309 \\
V-309\end{array}$ & biolita & & 1,46 & 82.86922 & 0.01276 & 0.00000 & 0.00011 & 82.83596 & 100.0 & 0.0086664 & $5.40 E-06$ & 1.0050 & 0.0014 & 15.3085 & $2.92 \mathrm{E}-13$ & 42 & SPAO203-71 & $01 / 24 / 03$ \\
\hline & $\begin{array}{l}V-309 \\
V-309\end{array}$ & biotita & 977.48 & 1.64 & 3.03925 & 0.01317 & 0.00000 & 0.00020 & 82.97883 & 99.9 & 0.0086664 & $5.40 E-06$ & 1.0050 & 0.0014 & 11.7757 & $2.24 E-13$ & 4.6 & SPA0203-71 & $01 / 24 / 03$ \\
\hline $1444-02 H$ & $V-309$ & biotita & 976.53 & 1.56 & 82.85822 & 0.01257 & 0.00000 & -0.00006 & 82.87405 & 100.0 & 0.0086664 & $5.40 \mathrm{E}-06$ & 1.0050 & 0.0014 & 25.7349 & $4.91 E-13$ & 5.2 & SPA0203-71 & $01 / 24 / 03$ \\
\hline 44-03 & $v-30$ & biotita & w & 3.36 & 76.79179 & 0.01383 & 0.00000 & 0.00548 & 75.17240 & 97.9 & 0.0086664 & $5.40 E-06$ & 1.0050 & 0.0014 & 1.3012 & $2.48 E-14$ & 0.9 & SPA0203-71 & $01 / 24 / 03$ \\
\hline $1444-038$ & V-309 & biotita & 940.15 & 1.85 & 78.94617 & 0.01288 & 0.00000 & 0.00040 & 78.91650 & 100.0 & 0.0086664 & $5.40 E-06$ & 1.0050 & 0.0014 & 4.9486 & $9.42 E-14$ & 1.5 & SPA.0203-71 & $01 / 24 / 03$ \\
\hline $1444-03 \mathrm{C}$ & $v-309$ & biotita & 935.86 & 1.85 & 78.45634 & 0.01277 & 0.00000 & 0.00000 & 78.45497 & 100.0 & 0.0086664 & $5.40 \mathrm{E}-06$ & 1.0050 & 0.0014 & 6.0451 & $1.15 E-13$ & 2.0 & SPA0203-71 & $01 / 24 / 03$ \\
\hline $1444-03 D$ & $V-309$ & biotita & 934.44 & 1.81 & 78.30434 & 0.01291 & 0.00000 & 0.00001 & 78.30200 & 100.0 & 0.0086664 & $5.40 \mathrm{E} \cdot 06$ & 1.0050 & 0.0014 & 4.5924 & $8.77 \varepsilon-14$ & 2.4 & SPA0203-71 & $01 / 24 / 03$ \\
\hline 1444-03E & V-309 & biotita & 331.08 & 1.76 & 78.04002 & 0.01308 & 0.02106 & 0.00034 & 77.94217 & 99.9 & 0.0086664 & $5.40 \mathrm{E} \cdot 06$ & 1.0050 & 0.0014 & 7.5058 & $1.43 E-13$ & 3.0 & SPA0203-71 & $01 / 24 / 03$ \\
\hline $1444-03 F$ & V-309 & biatita & 9 & 1.56 & 77.63931 & 0.01300 & 0.00025 & 0.00017 & 77.58987 & 99.9 & 0.0086664 & $5.40 \mathrm{E}-06$ & 1.0050 & 0.0014 & 20.2115 & $3.84 E-13$ & 4.2 & SPA0203-71 & $04 / 24 / 03$ \\
\hline 1444-.03G & V-309 & biotita & 923.25 & 2.41 & 77.17482 & 0.01262 & 0.01753 & 0.00024 & 77.10451 & 99.9 & 0.0086664 & $5.40 \mathrm{E}-06$ & 1.0050 & 0.0014 & 2.3295 & 4.44 & 4.7 & SPA0203-71 & $01 / 24 / 03$ \\
\hline $1444-03 \mathrm{H}$ & $v-309$ & biotita & $\begin{array}{l}927.17 \\
7 x^{2}\end{array}$ & 4.50 & 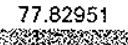 & 0.00973 & 0.05536 & 0.00106 & 77.52297 & 99.6 & 0.0086864 & $5.40 E-06$ & 1.0050 & 0.0014 & 0.7596 & $1.44 \mathrm{E}-14$ & 5.2 & SPA0203-71 & $01 / 24 / 03$ \\
\hline $1446-01 \mathrm{~A}$ & D.986 & biolita & 1577.85 & 79.8 & & & & 00707 & & & & & & & & & & & \\
\hline $1446-01 \mathrm{~B}$ & D-986 & biolita & 30128 & & 167.97230 & 0.00576 & 1.31219 & 0.02337 & 161.30420 & 95.9 & 0.0086664 & $5.40 \mathrm{E}-06$ & 1.0064 & 0.0013 & 0.0536 & $1.01 \mathrm{E}-15$ & 0.3 & $3-71$ & $01 / 02103$ \\
\hline $1446-0 \leqslant c$ & D-986 & biolita & 857.29 & $\begin{array}{l}8.48 \\
2.60\end{array}$ & 126.53870 & 0.01714 & 0.28136 & 0.01558 & 121.97770 & 96.4 & 0.0086664 & $5.40 \mathrm{E}-06$ & 1.0064 & 3 & 0.65 & $1.20 E-14$ & 0.6 & 3.71 & 203 \\
\hline $1446-010$ & D-986 & biolita & 804.99 & $\begin{array}{l}2.60 \\
1.67\end{array}$ & $\begin{array}{l}70.69856 \\
65.01606\end{array}$ & 0.01349 & 0.04738 & 0.00172 & 70.19357 & 99.3 & 0.0086664 & $5.40 \mathrm{E}-06$ & 1.0064 & 0.0 & 2.4152 & 4.60 & 0.9 & SPA0203-71 & $1 / 02 / 03$ \\
\hline 1446-01E & D.986 & biotita & 803.34 & 1.87 & $\begin{array}{l}65.01606 \\
6447673\end{array}$ & 0.01331 & 0.02460 & 0.00043 & 64.89152 & 39.8 & 0.0086664 & $5.40 \mathrm{E}-06$ & 1.0064 & 0.0013 & 3.3532 & $6.40 E-14$ & 1.2 & SPAO203-71 & $01 / 02 / 03$ \\
\hline $1446-01 F$ & D-986 & ofita & & 1.83 & $\begin{array}{l}4673 \\
7408\end{array}$ & 0.01274 & 0.00000 & 0.00007 & 64.72634 & 100.0 & 0.0086664 & $5.40 \mathrm{E}-06$ & 1.0060 & 0.0013 & 3.5313 & $6.74 E-14$ & 1.6 & SPA0203-71 & $01 / 03 / 03$ \\
\hline $1446-01 G$ & D-986 & iotita & 806.86 & 2.04 & .96667 & 0.01371 & 0.02604 & 0.00101 & 4.07812 & 99.5 & 0.0086664 & $5.40 E-06$ & 1.0060 & 0.0013 & 2.6086 & & 2 & 3.71 & 03 \\
\hline $1446-01 \mathrm{H}$ & D-986 & biotita & 829.75 & 1.58 & $\begin{array}{l}64.96667 \\
67.47092\end{array}$ & $\begin{array}{l}0.01280 \\
0.01324\end{array}$ & $\begin{array}{l}0.01079 \\
0.00664\end{array}$ & -0.00037 & 65.07814 & 100.2 & 0.0086864 & $5.40 E-06$ & 1.0060 & 0.0013 & 2.6374 & 5.0 & 2.6 & 3.71 & $103 / 03$ \\
\hline $1446-01\}$ & D.988 & biotita & 850.17 & 1.57 & 69.45862 & 0.01321 & $\begin{array}{l}0.00664 \\
0.00000\end{array}$ & 0.0 & $\begin{array}{r}67.38250 \\
696313\end{array}$ & 99.9 & 0.0086664 & $5.40 E-06$ & 1.0060 & 0.0013 & 9.5252 & $1.82 E-13$ & 3.8 & SPA0203-71 & $01 / 03 / 03$ \\
\hline & & & & & 00.7000 & & 0.000000 & 0.0000 & 69.46313 & 100.0 & 0.0086864 & $5.40 E-06$ & 1.0060 & 0.0013 & 11.0870 & $2.1+E-13$ & 5.2 & SPA0203-71 & 01/03/03 \\
\hline $1446-02 A$ & D & ita & & 2.95 & 3 & & & 0 & & 98 & & & & & & & 0 & & 03 \\
\hline $1446-028$ & D-986 & biotita & 3.02 & 1.95 & 68.80707 & 0.01307 & & & & 39 & & $5.40 E-06$ & 1.0050 & 0.0014 & 4.9830 & $9.51 E-14$ & 1.2 & $203-71$ & $01 / 24 / 03$ \\
\hline $1446-02 \mathrm{C}$ & D-986 & biotita & 865.56 & 1.76 & & 0.01265 & 0.00 & -0.00 & 71.04636 & 100.0 & 0.0088664 & $5.40 E-06$ & 1.0050 & 0.0014 & 5.9603 & $1.14 E-13$ & 1.6 & $203-71$ & $01 / 24 / 03$ \\
\hline $1446-02 \mathrm{D}$ & D-986 & biotita & 86536 & 1.47 & 056 & 0.01248 & 0.00000 & -0.00046 & 71.02563 & 100.2 & 0.0086664 & $5.40 \mathrm{E}-06$ & 1.0050 & 0.0014 & 4.8838 & 9.31 & 2 & & \\
\hline $1446-02 E$ & D-986 & biotita & 869.40 & 1.58 & 48921 & 0.01317 & 0.00000 & 0.00015 & 71.44341 & 99.9 & 0.0086664 & $5.40 \mathrm{E}-06$ & 1.0050 & & & & 2.8 & & \\
\hline $1446-02 F$ & $0-986$ & biotita & 3.40 & 1.73 & 83531 & 01262 & 0.00000 & -0.00 & & 100.1 & & & 1.0050 & 0.0034 & 7.5776 & & 3.6 & $3-71$ & $01 / 24 / 03$ \\
\hline $1446-02 \mathrm{G}$ & D-986 & biotita & 7.28 & 2.12 & 70.01826 & 1172 & 0. & -0.00059 & 70.19328 & 100.3 & 0.00 & 5.40 & 1.0050 & 0.0 & 3.1532 & 6.0 & 4.4 & $3-71$ & $01 / 24 / 03$ \\
\hline $1446-02 \mathrm{H}$ & D-986 & biolita & 810.67 & 1.96 & 65.65457 & 0.01311 & 0.00000 & 0.00056 & 65.45940 & 99.7 & 0.0086664 & $5.40 \mathrm{E}-06$ & 1.0050 & 0.0014 & 1.8322 & $3.50 \mathrm{E}$ & 5.2 & SPA0203-71 & $01 / 24 / 03$ \\
\hline & & & & 7 & & & & & & 9 & & & & & & & & & \\
\hline $1446-03 B$ & D-986 & ita & & 1. & & 326 & & & & $9 s$ & & & 1.0 & 0.0 & 5.0 & -14 & 1.2 & 3.71 & $4 / 03$ \\
\hline $1446-03 \mathrm{C}$ & D & ita & 1.85 & 2.00 & 74 & & & & 33 & 100.0 & & 5.4 & 1.0 & 0. & 3.5605 & & 1.8 & & $4 / 03$ \\
\hline & D & lita & 25 & 1.82 & & 316 & & 0 & & 99. & & & & & 2.7263 & & 2 & & 3 \\
\hline $1446-03 E$ & $0-986$ & & & $\{.47$ & & 14 & & & & 95 & & & 1.0 & 0.0 & & & & & \\
\hline $1446-03 \mathrm{~F}$ & & ita & & 1.70 & 93 & 0 & 2737 & 0065 & 66.01698 & 99.7 & & $5.40 \mathrm{E}-06$ & & 0.0 & & & 4. & & $01 / 25 / 03$ \\
\hline $1446-03 G$ & D-986 & biotita & 822.71 & 2.28 & 87598 & $0.0 \div 294$ & 0.04618 & 0.00071 & 66.67020 & 99.7 & 0.008 & $5.40 E-06$ & 1.0067 & 0.001 & 2.1517 & $4.09 E-14$ & 5.2 & 203.71 & $01 / 25 / 03$ \\
\hline & & & & & & & & & & & & & & & & & & & \\
\hline $\begin{array}{l}1449-01 \mathrm{~A} \\
1449-01 \mathrm{~B}\end{array}$ & $\begin{array}{l}V-332 \\
V-332\end{array}$ & $b$ & 0.09 & & & 1636 & 0.82 & & 50.05770 & 85. & & 5.40 & 1.0 & & 0.0855 & 1.6 & 0.3 & $203-71$ & \\
\hline 1449-01B & & & & 3.1 & & 0.01494 & & & & 99.3 & & & 1.0060 & 0.0 & 1.3706 & & 0.6 & 203.71 & $01 / 03 / 03$ \\
\hline $1449-$ & & & & 2. & & & & & 75.25499 & 100.0 & & & 1.0 & 0.0 & 2.5 & & 0 & 71 & $01 / 03 / 03$ \\
\hline $1449-0$ & & & & & 74.72062 & 0.01531 & 0.00000 & & & 100 & & & & & & & 1 & 71 & 33 \\
\hline $1449.01 \mathrm{E}$ & & & & 2.05 & 74.40036 & 0.01536 & 000876 & & & & & & & & 3.8 & & 1.7 & .71 & 3 \\
\hline $1449.01 \mathrm{~F}$ & & & & 2.07 & & & & & & & & 5.40 & & 0.0 & & & & & \\
\hline & v. & & & 1 & & & & & & 99.7 & & & & & & & 2. & & \\
\hline $1449-01 \mathrm{H}$ & $\mathrm{v}$ & & & & & & & -0.00043 & & 100 & & & & & & & 3.9 & & \\
\hline $1449-011$ & V-332 & biolita & 905.23 & 1.70 & 75.16968 & 0.01497 & .000 & .0 .00007 & 75.19151 & 100. & 0.00 & $5.40 E \cdot 06$ & 1.0060 & 0.0013 & 6.3770 & 1.21E-13 & 5.2 & SPA0203-71 & $1103 / 03$ \\
\hline & & & & & & & & & & & & & & & & & 0. & & \\
\hline & & & & 1.5 & & & & & & 99.9 & & & & & & & 1 & & \\
\hline $1449.02 \mathrm{C}$ & & & & & & & & & & 100.0 & & & & & & & 1 & 71 & 103 \\
\hline & & & & & & 192 & & & & 10 & & & & & & & 2. & 3.71 & $01 / 25 / 03$ \\
\hline $1449-02 E$ & & & & & & & & & & & & & & & & & 2. & $3-71$ & 03 \\
\hline $1449-02 F$ & $V-332$ & iotila & & 53 & 76.88171 & 0.01599 & 0.00000 & 0.00011 & 76.84874 & 100.0 & 0.0086664 & $5.40 \mathrm{E}-06$ & 1.0067 & 0.0013 & 10.7154 & $2.05 E-13$ & 4.0 & SPA0203-71 & $1 / 25 / 03$ \\
\hline
\end{tabular}




\begin{tabular}{|c|c|c|c|c|c|c|c|c|c|c|c|c|c|c|c|c|c|c|c|}
\hline Run ID\# & Sample & ateri. & $\begin{array}{l}\mathrm{Ag} \& \\
(\mathrm{Ma})\end{array}$ & $\begin{array}{c} \pm \\
(\mathrm{Ma})\end{array}$ & $40 / 39$ & $38 / 39$ & $1 / 39$ & $8 / 39$ & $40 \% / 39$ & $\% \operatorname{Rad}$ & 3 & \pm & iscr. & \pm & $\begin{array}{l}\text { Ar40 } \\
(n A)\end{array}$ & $\begin{array}{l}\text { Ar40 } \\
\text { (mols) }\end{array}$ & $\begin{array}{l}\text { Laser } \\
\text { (W) }\end{array}$ & Irrad. & Run Date \\
\hline $1449-026$ & v-332 & biolita & $\$ 24.84$ & 1.75 & 77.18346 & 0.01532 & 2.00000 & -0.00031 & 77.27430 & 700.1 & 0.0086664 & $5.40 E-06$ & 1.0067 & 0.0013 & 4.4409 & $8.45 E-14$ & 5.2 & SPA0203-71 & $01 / 25 / 03$ \\
\hline $1449.03 \mathrm{~A}$ & V-332 & biotita & 903.75 & 2.32 & 75.88104 & 0.014 & & & 75.03545 & 9 & 4 & 6 & 067 & 3 & 2.0453 & $39 E-14$ & 0.6 & 71 & $01 / 25 / 03$ \\
\hline $1449-03 B$ & V.332 & jotita & 6.67 & & .45805 & 0.01457 & 0.00000 & 0.00018 & 76.40411 & 99.9 & 0.0086664 & $5.40 E-06$ & 1.0067 & 0.0013 & 6.5417 & $1.25 \mathrm{E}-13$ & 1.1 & SPA0203-71 & $01 / 25 / 03$ \\
\hline $1449.03 \mathrm{C}$ & V-332 & biotita & 7.00 & 1.59 & 76.48259 & .01423 & 0.00000 & 0.00015 & 76.43906 & 99.9 & 0.0086664 & $5.40 \mathrm{E}-06$ & 1.0067 & 0.0013 & 5.3549 & $1.02 E-13$ & 1.6 & SPA0203-71 & $01 / 25 / 03$ \\
\hline $1449-030$ & $v-332$ & biotita & 100 & 1.64 & 76.52750 & 0.01388 & 0.00000 & .0 .00006 & 76.54575 & 100.0 & 0.0086664 & $5.40 E \cdot 06$ & 1.0067 & 0.0013 & 5.0234 & $9.55 \mathrm{E}-14$ & 2.2 & PA0203-71 & $01 / 25 / 03$ \\
\hline 1449.03E & V-332 & biotita & 1.63 & 1.89 & 76.94336 & 0.01443 & 0.00000 & 0.00004 & 76.93163 & 100.0 & 0.0086684 & $5.40 \mathrm{E} \cdot 06$ & 1.0067 & 0.0013 & 6.9907 & $1.18 \mathrm{E}-13$ & 2.9 & PA0203-71 & $01 / 25 / 03$ \\
\hline $1449-03 \mathrm{~F}$ & $v-332$ & biotita & 922.53 & 1.80 & 77.01981 & 0.01410 & 0.00000 & .0 .00003 & 77.02746 & 100.0 & 0.0086664 & $5.40 \mathrm{E}-06$ & 1.0067 & 0.0013 & 7.0696 & 3 & 4.0 & SPA0203-71 & $01 / 25 / 03$ \\
\hline $1449.03 G$ & V-332 & biotita & 922.09 & 1.83 & 76.87016 & 0.01314 & 0.00000 & -0.00037 & 76.98054 & 100.1 & 0.0086664 & $5.40 E-06$ & 1.0067 & 0.0013 & 4.8024 & $9.13 E-14$ & 5.2 & 203-71 & $01 / 25 / 03$ \\
\hline 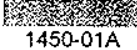 & GR-29 & tia & & & & & & & & & & & & & & & & & \\
\hline $\begin{array}{l}1450-01 \mathrm{~A} \\
1450-018\end{array}$ & $\begin{array}{l}\text { GR-29 } \\
\text { GR-29 }\end{array}$ & $\begin{array}{l}\text { biotifa } \\
\text { biolita }\end{array}$ & $\begin{array}{l}735.82 \\
93380\end{array}$ & 25.55 & 74.29149 & 0.05746 & 0.46495 & 0.05495 & 58.11019 & 78.2 & 0.0086664 & $5.40 \mathrm{E}-06$ & 1.0060 & (2) & 0.090 & $1.71 \mathrm{E}+15$ & 0.3 & $3-71$ & $103 / 03$ \\
\hline $\begin{array}{l}1450-018 \\
1450-01 C\end{array}$ & $\begin{array}{l}\text { GR-29 } \\
\text { GR-29 }\end{array}$ & & 933.80 & 3.85 & 79.95625 & 0.01844 & 0.15042 & 0.00589 & 78.23386 & 97.8 & 0.0086664 & $5.40 E-06$ & 1.0060 & 0.0013 & 0.9408 & 1.78 & 0.6 & SPA0203-71 & $3 / 03$ \\
\hline $1450-01 \mathrm{C}$ & $\begin{array}{l}\text { GR-29 } \\
\text { GR-29 }\end{array}$ & olita & 18.54 & 2.6 & 9.53547 & 0.01625 & 0.03104 & 0.00269 & 78.74311 & 99.0 & 0.0086664 & 5.4 & 1.0060 & 0.0013 & 1.8140 & & 0.9 & 71 & $1 / 03 / 03$ \\
\hline $1450-010$ & GR-29 & a & 3.13 & 2.6 & 78.82463 & 0.01554 & 0.04 & 0.00 & 78.18 & 99.2 & 0.0086664 & $5.40 E-06$ & 1.0060 & 0.0013 & 1.5404 & -14 & 1.2 & SPA0203-71 & $01 / 03 / 03$ \\
\hline OHE & GR-29 & a & 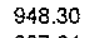 & . & 79.99449 & .01464 & 0.11113 & 0.000 & 79.79635 & 99.7 & 664 & $5.40 E .06$ & 1.0060 & 0.0013 & 1.1163 & $2.12 \mathrm{E}-14$ & $\{.6$ & SPA0203-71 & $1 / 03 / 03$ \\
\hline $1450-01 F$ & GR-29 & biotita & 7.64 & 4.92 & 78.95738 & 0.01519 & 0.00000 & 0.00105 & 8.64606 & 99.6 & 86664 & $5.40 E-06$ & 1.0060 & 0.0013 & 0.6767 & & 2.0 & 31 & 03 \\
\hline $1450.01 G$ & GR-29 & biolita & 932.63 & 3.48 & 79.03430 & 0.01642 & 0.02351 & 0.00315 & 78.1 & 98.8 & 0.0 & 5.4 & 60 & 13 & 1.2 & & 2.7 & & $03 / 03$ \\
\hline 1450-01H & GR-29 & biolita & 94404 & 2.1 & 79.72336 & 0.01525 & 9 & 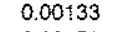 & 79. & 99.5 & & 5.4 & 1.0060 & 0.0013 & 2.4287 & & 3.8 & 71 & $1 / 03 / 03$ \\
\hline 1450-01! & GR-29 & biotita & 0.64 & 6.66 & 79.45074 & 0.01516 & 19826 & 0.00172 & 78.96873 & 99.4 & 0.0086664 & $5.40 \mathrm{E}-06$ & 1.0060 & 0.0013 & 0.4589 & $8.73 E-15$ & 5.2 & SPA0203-71 & $01 / 03 / 03$ \\
\hline $1450-02 A$ & GR-2 & tita & 500 & 4.75 & & 154 & & & & 98 & & & & .0013 & 8 & 4 & 5 & & 3 \\
\hline $1450-02 B$ & GR-29 & biotita & 1.5 & 2.8 & 6.38 & 3 & 0 & 11 & 01 & 99.2 & & 5.4 & 1.0067 & 0.0013 & 1.6951 & & 0.8 & & 6103 \\
\hline $1450-02 \mathrm{C}$ & GR-29 & biotitla & 1929 & 26 & 76.04554 & 0.01515 & 00000 & 0.00144 & 15 & 99.4 & & $5.40 \mathrm{E}-06$ & 1.0067 & 0.0013 & 1.4423 & & 1.2 & SPA0203-71 & $1 / 25103$ \\
\hline $1450-02 D$ & GR-29 & & & 3.36 & 76.92730 & 0.01361 & 80000 & 0.00074 & 6.70825 & 99.7 & 684 & $5.40 \mathrm{E}-06$ & 1.0067 & 0.0013 & 1.2937 & & & SPAO203-71 & \\
\hline $1450-$ & GR-29 & & & 2.13 & 76.05442 & 0.01445 & 00000 & 0.00075 & 75.83229 & 99.7 & & & & & & & & & \\
\hline $1450-02 \mathrm{~F}$ & GR-29 & biobita & 914.09 & 2.05 & 76.36446 & 0.01425 & 0.02056 & 0.00080 & & 99.7 & & & & 0.0013 & & & & & \\
\hline $1450-02 G$ & GR-29 & biotita & 919.31 & 3.27 & 5.44897 & 0.01138 & 0 & & & 100.3 & & 06 & 1.0067 & 0.0013 & 1.1049 & & 4.0 & & $/ 03$ \\
\hline $1450-02 \mathrm{H}$ & GR-29 & biotita & 919.18 & 13.40 & 78.43873 & 0.02020 & .53867 & 0.00622 & 76.67089 & 97.7 & 0,0086664 & $5.40 E-06$ & 1.0067 & 0.0013 & 0.1982 & $3.78 E-15$ & 5.2 & SPA0203-71 & $01 / 25 / 03$ \\
\hline & & & & & & & & & & 9 & & & & & & & & & \\
\hline $1450-038$ & GR-29 & tita & 5.48 & 58 & 44859 & 1511 & 1 & 0 & & 9 & & & & & & & & & 103 \\
\hline $1450-03 \mathrm{C}$ & GR-29 & tita & 955 & 3.68 & & & & & & & & & & 13 & & & 1.3 & & 503 \\
\hline $1450-03 \mathrm{D}$ & GR-29 & ita & & & & 0.01362 & & -0.00 & & 100.6 & & & & 13 & & & 2.0 & & $5 / 03$ \\
\hline & GR-29 & & & 2. & 61 & 70 & serat & & & 99.4 & & & & 3 & & & & -71 & $5 / 03$ \\
\hline 1450 & GR-29 & & & 2.56 & 76.1 & 1659 & 0 & 0 & & 99 & & & & 3 & & & & & \\
\hline $1450-036$ & GR-29 & biotita & 914.71 & 5.62 & 76.24485 & 0.01484 & 0.50793 & 0.00039 & & 99 & & & & 0.00 & 2.5 & 1.03 & 5.2 & 71 & $01 / 25 / 03$ \\
\hline & & & & & & & & & & & & & & & & & & & \\
\hline $1452.01 \mathrm{~B}$ & V-198 & & & & & 00297 & & & & 199.5 & & & & 3 & & & 0.3 & 71 & 103 \\
\hline 1 & V-19 & & & & 03 & 1607 & & & & of & & & & & & & & & \\
\hline & $V-19$ & & & & & & & & & & & & & & & & & & \\
\hline & $\begin{array}{l}V-198 \\
V-198\end{array}$ & & & $\begin{array}{l}0 . \\
0 .\end{array}$ & & & & & & 10 & & & & & & & 1. & & 103 \\
\hline $\begin{array}{l}1452 \\
1452\end{array}$ & $\begin{array}{l}V-198 \\
V-198\end{array}$ & & & & & & & & & & & & & & & & & & \\
\hline$\$ 45$ & $\begin{array}{l}v-198 \\
v-198\end{array}$ & & & & & & & & & & & & & & & & & & 03 \\
\hline 14 & $V-198$ & & & & & & & & & 10 & & & & & & & & & \\
\hline$\{452-01 H$ & $V-198$ & & & & & & & -0.00003 & 21.25174 & 100.0 & & & & 0.8 & & & 3. & & \\
\hline 1452.011 & $V-198$ & iotita & 43 & 1.86 & 69706 & 0.01404 & 0.01148 & -0.00063 & 18.88357 & 101.0 & 664 & $5.40 E-06$ & 1.00 & 0.0013 & 0.3617 & $6.90 \mathrm{E}-$ & 5.2 & SPA0203-71 & $01 / 03 / 03$ \\
\hline & & & & & & & & & & & & & & & & & & & \\
\hline 1 & v & & & & & & & & & 99 & & & & & & & & & \\
\hline $1452-0$ & v- & & & & & 85 & & & & 99 & & & & & & & & & \\
\hline $1452-020$ & V.198 & & & 0 & & & & & & & & & & & & & & 71 & 03 \\
\hline & $V-198$ & & & & & & & & & & & & & 13 & & & & & \\
\hline & $V-198$ & & & & & & & & & 100.1 & & & & & & & & & 03 \\
\hline $1452-02 G$ & $V-198$ & biolita & 294.60 & 1.18 & .53998 & .01440 & 0.005 & 0.00024 & 20.46797 & 99.7 & 0.0086684 & $5.40 E-06$ & 1.006 & 0.0013 & 0.6285 & $20 \mathrm{E}-14$ & 5.2 & SPA0203-71 & $01 / 25 / 03$ \\
\hline & & & & & & & & & & & & & & & & & 6 & & \\
\hline & & & & & & & & & & & & & & & & & & & \\
\hline & & & & & & & & & 37.01813 & 100.1 & & & & & & & & & $01 / 25 / 03$ \\
\hline & & & & & & & & & & & & & & & & & & & \\
\hline & & & & & & & & & & 100.0 & 086664 & & & & & & & & \\
\hline
\end{tabular}




\begin{tabular}{|c|c|c|c|c|c|c|c|c|c|c|c|c|c|c|c|c|c|c|c|}
\hline Run & Sample & Material & $\begin{array}{r}\text { Age } \\
\text { (Ma) }\end{array}$ & $\underset{(\mathrm{Ma})}{ \pm}$ & $40 / 39$ & $38 / 39$ & $37 / 39$ & $36 / 39$ & $40^{ \pm} / 39$ & $\% \operatorname{Rad}$ & $J$ & \pm & Discr. & \pm & $\begin{array}{l}\text { Ar40 } \\
(n A)\end{array}$ & $\begin{array}{l}\text { Ar40 } \\
\text { \{mots\} }\end{array}$ & $\begin{array}{l}\text { Laser } \\
\text { (W) }\end{array}$ & Irrad. & Run Date \\
\hline $1452.03 \mathrm{~F}$ & V-198 & biotita & 475.53 & 0.92 & 34.83202 & 0.01475 & 0.00000 & 11 & 4.79967 & 99.9 & 0.00866 & $5.40 E-06$ & 1.0067 & 0.0013 & 4.2894 & $8.20 \mathrm{E}-14$ & 3.8 & SPA0203-7i & $01 / 26 / 03$ \\
\hline $1452-03 G$ & $V-198$ & biotita & 444.21 & 1.59 & 32.36095 & 0.01566 & 0.02431 & 0.00050 & 32.21500 & 99.5 & 0.0086664 & $5.40 E-06$ & 1.0067 & 0.0013 & 0.7556 & $1.44 \mathrm{E}-14$ & 5.2 & SPAO203-71 & 01126103 \\
\hline $1453-01 \mathrm{~A}$ & C. 271 & biolita & 586.93 & 25.51 & 47.64087 & 0.03897 & & & & & & & & & & & & & \\
\hline 1453-01B & C-271 & biolita & 996.81 & 3.38 & 84.94026 & 0.01211 & $\begin{array}{l}0.42518 \\
0.00000\end{array}$ & $\begin{array}{r}0.01124 \\
-0.00059\end{array}$ & 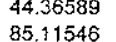 & $\begin{array}{l}93.3 \\
100.2\end{array}$ & 0.0086664 & $\begin{array}{l}5.40 E-06 \\
5.40 \mathrm{E}-06\end{array}$ & 1.0060 & 0.0013 & 0.0443 & $8.37 E-16$ & 0.3 & SPA0203-71 & 01103103 \\
\hline $1453-01 \mathrm{C}$ & C.271 & biotita & 1030.18 & 2.99 & 89.00968 & 01313 & 0.00000 & 0.00051 & 88.85841 & $\begin{array}{l}700.2 \\
99.8\end{array}$ & 0,0086664 & $\begin{array}{l}5.40 \mathrm{E}-06 \\
5.40-06\end{array}$ & 1.0060 & 0.0013 & 1.0778 & $2.05 E-14$ & 0.6 & SPA0203-71 & $0103 / 03$ \\
\hline 1453-01D & C-271 & biotita & 1040.15 & 2.31 & .76579 & 01206 & 0.00000 & -0.00 & 89. & 10 & 0.008 & $\begin{array}{l}5.40 E-06 \\
5.40 E-06\end{array}$ & 1.0060 & 0.0013 & 2.9139 & 5.54 & 0.9 & SPA0203-71 & $01 / 03 / 03$ \\
\hline 1453-01E & $C-271$ & biotita & 1034.93 & 1.90 & 16377 & 0 & 000382 & & & & 00086664 & $\begin{array}{l}5.40 \mathrm{E}-06 \\
5.40 \mathrm{E}-06\end{array}$ & 1.0060 & 0.0013 & 3.3975 & $6.46 \mathrm{E}-14$ & 1.2 & SPA0203-71 & $01 / 03 / 03$ \\
\hline $1453.01 F$ & $C-271$ & bioltla & 1023. & 2 & 31 & & & & 39 & & $\begin{array}{l}0.00856664 \\
0.008664\end{array}$ & $\begin{array}{l}5.40 E-06 \\
5.40 E-06\end{array}$ & 1.0060 & 0.0013 & 2.6488 & $5.05 E-14$ & 1.6 & SPA0203-71 & $01 / 03 / 03$ \\
\hline $1453.01 \mathrm{G}$ & C-271 & biotita & 1028.66 & 2.91 & 88.47651 & $\begin{array}{l}0.01170 \\
0.01242\end{array}$ & 0.000000 & $\begin{array}{l}-0.00141 \\
.000071\end{array}$ & $\begin{array}{l}88.06 \\
8868\end{array}$ & $\begin{array}{l}100.5 \\
100.2\end{array}$ & 0.0086664 & $\begin{array}{l}5.40 E-06 \\
5.40 E-06\end{array}$ & $\begin{array}{l}1.0060 \\
10060\end{array}$ & 0.0013 & $\begin{array}{l}1.5249 \\
20509\end{array}$ & 14 & 2.0 & 03.71 & $01 / 03 / 03$ \\
\hline 1453-01H & C. 271 & biotita & $\{033.32$ & 1.95 & 9.22221 & 0.01273 & 0.02335 & 0.00004 & 89.21436 & 100.0 & 0.0086664 & 5.40 & 1.0060 & $\begin{array}{l}0.0013 \\
0.0013\end{array}$ & $\begin{array}{l}2.0509 \\
4.7142\end{array}$ & & 2.7 & & \\
\hline 1453.011 & C-271 & biotita & 1022.34 & 2.74 & 87.99911 & 0.01357 & 0.01568 & 0.00009 & 87.97338 & 100.0 & 0.0086664 & $5.40 E \cdot 06$ & 1.0060 & 0.0013 & 2.2208 & $\begin{array}{l}8.93 E-14 \\
4.23 E-14\end{array}$ & 5.2 & $\begin{array}{l}\text { SPA0203-71 } \\
\text { SPA0203-71 }\end{array}$ & $\begin{array}{l}01 / 03 / 03 \\
01 / 03 / 03\end{array}$ \\
\hline $1453-02 \mathrm{~A}$ & $C-271$ & & .75 & 3.35 & 99958 & 0.01106 & 0.00000 & 0150 & 1351 & 100.5 & 0.0080664 & $5.40 E-06$ & 1.0067 & 0.0013 & 12895 & 4 & 6 & & \\
\hline 1453.028 & $C-271$ & ita & 1018.28 & 2.92 & 87.15884 & 0.01068 & 0.00000 & -0.00121 & 87.51637 & 100.4 & 0.00 & $5.40 E-06$ & 1.0067 & 0.0013 & 2.0868 & 3.9 & 0.9 & SPA0203-71 & $01 / 26103$ \\
\hline $1453-02 \mathrm{C}$ & $C-271$ & biolita & 1021.41 & 3.72 & 87.16125 & 0.01081 & 0.00000 & -0.00240 & 87.86883 & 100. & 0.0086664 & $5.40 E-06$ & 1.0067 & 0.0013 & 1.3204 & 14 & 1.2 & SPA0203-71 & $01 / 26 / 03$ \\
\hline 1453-02D & C-271 & biobita & 1017.76 & 3.26 & 87.03284 & 0.01 & 0.03273 & .0 .00 & 87.45735 & 100.5 & 0.0086664 & $5.40 \mathrm{E}-06$ & 1.0067 & 0.0013 & 1.0422 & $1.98 E-14$ & 1.6 & SPA0203-71 & 103 \\
\hline 1453-02E & C-271 & biolita & 1017.68 & 3.61 & 02152 & 0.01022 & 0.00000 & -0.00145 & 87.44909 & 100.5 & 0.0086664 & $5.40 E-06$ & 1.0067 & 0.0013 & 1.1984 & & 2.2 & & 03 \\
\hline $1453-02 F$ & C-271 & & 1019.16 & 1.92 & 87.41167 & 0.01177 & 0.00000 & -0.00069 & 87.61457 & 100.2 & 0.0086664 & $5.40 E-06$ & 1.0067 & 0.01 & 38 & & 9 & 71 & $01 / 26 / 03$ \\
\hline $1453-02 G$ & C-271 & biolita & 1011.30 & 2.76 & 86.83074 & 0.01293 & 0.00000 & 0.00033 & 86.73300 & 99.9 & 0.0086664 & 5.40 & 1.0067 & 0.0013 & 2.4602 & & 3.8 & SPA0203-71 & $01 / 26 / 03$ \\
\hline $1453-02 \mathrm{H}$ & $C-271$ & biolita & 1026.56 & 5.16 & 87.29560 & 0.00780 & 0.00000 & -0.00391 & 88.44990 & 101.3 & 0.0086664 & $5.40 \mathrm{E}-06$ & 1.0067 & 0.0013 & 0.6983 & 1.33E-14 & 5.2 & SPA0203-71 & $01 / 26 / 03$ \\
\hline 1453 & C-271 & & 10 & 2.78 & 03 & 0 & 0.06545 & 0.004 & 88.92444 & 98.6 & 0.00 & 5.40 & 1.00 & 13 & & 4 & 6 & 1 & 03 \\
\hline $1453.03 B$ & $C-271$ & ita & 1051.27 & 2.40 & 91.45090 & 0.01344 & 0.04557 & 0.00066 & 91.2 & 99.8 & & 5.40 & 1.0067 & 0.0013 & 2.9448 & & 0.9 & SPA0203-71 & $01 / 26 / 03$ \\
\hline $1453-03 \mathrm{C}$ & C-27i & biotita & 1044.05 & 2.59 & 90.78866 & 0.01341 & 0.04757 & 0.00122 & 90.43502 & 99.8 & 0.0086664 & $5.40 \mathrm{E}-06$ & 1.0067 & 0.0013 & 2.8419 & $: 14$ & 1.2 & SPAO203-71 & $01 / 26 / 03$ \\
\hline $1453-030$ & C-271 & & 1041. & 2.02 & 90.1 & 0.01217 & 0.01320 & 0.00012 & 90.12746 & 100.0 & 0.0086664 & $5.40 \mathrm{E}-06$ & 1.0067 & 0.0013 & 4.7695 & 9.1 & 1.9 & & \\
\hline $1453-0$ & C.271 & & 1046.06 & 2.00 & 90.82537 & 01292 & 0.04181 & 0.00056 & 90.66446 & 99.8 & 0.0086664 & $5.40 \mathrm{E}-06$ & 1.00 & 0.04 & & & 2.8 & & $01 / 26 / 03$ \\
\hline $1453-03 F$ & C. 271 & biotita & 3046.11 & 1.99 & 90.79049 & 0.01229 & 0.02384 & 0.00042 & 90.67003 & 99.9 & 0.0086664 & $5.40 \mathrm{E}-06$ & 1.0067 & 0.0013 & 7.2512 & & 3.8 & SPA0203-71 & $01 / 26 / 03$ \\
\hline $1453-03 G$ & C. 271 & biofita & 1036.71 & 1.72 & 89.60714 & 0.01197 & 0.00000 & 0.00002 & 89.59957 & 100.0 & 0.0086664 & $5.40 \mathrm{E}-06$ & 1.0067 & 0.0013 & 5.0062 & $9.53 E-14$ & 5.2 & SPAO203-71 & $01 / 26103$ \\
\hline $1455.01 \mathrm{~A}$ & $c-302$ & biotita & 296.19 & 17.91 & 21.29934 & 73 & & 40 & 33 & & & & & & & & & & \\
\hline & & & 893.26 & 8.04 & 680 & 3141 & 0000 & & 3.93088 & 71.9 & $\begin{array}{l}0.0086664 \\
0.0086664\end{array}$ & $\begin{array}{l}5.40 E-06 \\
5.40 E-06\end{array}$ & $\begin{array}{l}1.0060 \\
1.0060\end{array}$ & 0.0013 & 0.0307 & $5.85 E-16$ & 0.3 & 71 & 3 \\
\hline $1455-0$ & C-302 & & 988.73 & 2 & & 0 & 0000 & & & 97 & & & & & & & 6 & & \\
\hline $1455-010$ & C-302 & & 1010.04 & 2 & 62 & 71 & & & & 99 & & 5.40 & 18 & 0.0 & & & 0.9 & $3-71$ & $01 / 03 / 03$ \\
\hline 1455-0价 & C-302 & & 1009.51 & 2. & & 29 & 00000 & 00038 & 6.53225 & 99 & & 5.40 & 1.0060 & 0.0013 & $\begin{array}{l}6.3814 \\
10.8606\end{array}$ & 3 & 1.2 & SPA0203-71 & $01 / 04 / 03$ \\
\hline $1455.01 \mathrm{~F}$ & C-302 & 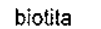 & to & 1. & 8 & & & & & & & & 10050 & 0.0013 & & & 1.6 & & \\
\hline 1455 & C. 3 & & & & & 54 & & & & & & & & & & & 2.0 & & 103 \\
\hline $1455-01 \mathrm{H}$ & C-302 & & 1020.26 & 1. & & & & 0 & 77. & 100.0 & & 5.4 & & 0.00 & & & 2.7 & 3.71 & $1 / 04 / 03$ \\
\hline $1455-011$ & C-302 & biotita & 1002.06 & 1.94 & $\begin{array}{l}87.81542 \\
85.71284\end{array}$ & $\begin{array}{l}0.01469 \\
0.01382\end{array}$ & $\begin{array}{l}0.00000 \\
0.00000\end{array}$ & & $\begin{array}{l}87.73943 \\
85.70017\end{array}$ & $\begin{array}{r}99.9 \\
800\end{array}$ & 0.09 & $\begin{array}{l}5.40 \mathrm{E}-06 \\
5.40 \mathrm{E}-06\end{array}$ & 1.0060 & .00 & 68 & & 8 & 3.71 & $104 / 03$ \\
\hline & & & & & & & & & 00.1 (1) & 800 & 0.0 & & & .00 & 18.6845 & $3 f^{2}$ & 2 & SPA0203-71 & $01 / 04 / 03$ \\
\hline 1455 & & & & & & & & & & & & & & & & & 0.6 & & \\
\hline & & & & & & & & & & 99 & & 5.4 & $t$. & 0.00 & & & 1.0 & & $6 / 03$ \\
\hline $\begin{array}{l}14555-02 C \\
1455-02 D\end{array}$ & & & & & & 1429 & & & & 100 & & & & & & & 14 & 71 & \\
\hline $1455-02 E$ & c-302 & 等i & $\begin{array}{r}955 \\
954\end{array}$ & 1. & & 53 & & & & & & & & & & & & & \\
\hline & C-3 & & 95 & & & & & & & 99 & & & & & & & & & \\
\hline 1455- & $c-3$ & & $\begin{array}{l}95 \\
94\end{array}$ & 2. & & & & & 889 & 100.2 & & & & 0.0 & & & 3. & & \\
\hline $1455-02 \mathrm{H}$ & C-302 & biotita & 949.60 & 2.13 & $\begin{array}{l}79.77528 \\
79.92805\end{array}$ & $\begin{array}{l}0.01466 \\
0.01418\end{array}$ & $\begin{array}{l}0.01635 \\
0.00000\end{array}$ & $\begin{array}{l}0.00013 \\
.0 .00003\end{array}$ & 39.9 & $\begin{array}{l}100 \\
100\end{array}$ & & & & 0.0 & & & $\ldots$ & $3-71$ & 26103 \\
\hline & & & & & & & & & 9.936 & 100 & & 5.40 & 1.0067 & 0.0013 & 4.2574 & -14 & 5.2 & PAO203-71 & $1 / 26 / 03$ \\
\hline & & & & & & & & & & & & & & & & & 0.0 & & \\
\hline & & & & & & & & & & 99 & & & & & & & 1.0 & & \\
\hline $\begin{array}{l}14 \\
14 \\
\text { (n) }\end{array}$ & & & 0 & 16 & 02 & 374 & & & & 99 & & & & & & & 1.4 & 3.71 & 103 \\
\hline 1455-03E & c & & 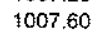 & 1 & & & & & & & & & 1.0 & 0.0 & & & & & \\
\hline & & & & & & & & & & 99.9 & & 5.4 & & 00 & & & & & \\
\hline & & & & & & 1449 & & 0054 & 19674 & $\begin{array}{l}99.8 \\
90.9\end{array}$ & & & & & & & 0 & & \\
\hline 5-03H & 302 & biolita & 1003.11 & 3.23 & 85.87354 & 0.0 & $\begin{array}{l}0.00 \\
0.00\end{array}$ & $\begin{array}{l}0.00019 \\
0.0019\end{array}$ & & 99.9 & & & & & & & 4.1 & 3-71 & $01 / 26 / 03$ \\
\hline & & & 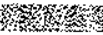 & & & . & 0 & & 85.816 & 99.9 & 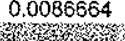 & $5540 E-06$ & 1.0067 & 0.013 & 2.3033 & $4.39 \mathrm{E}-14$ & 5.2 & SPA0203-71 & $01 / 26$ \\
\hline & & & 07 & 38 & 70540 & 0. & & & & 99.4 & & & & 0.6 & & & & & \\
\hline & & & 959.73 & 2.02 & 98923 & 1611 & 0.00000 & -0.00016 & 3648 & 100.1 & 0.0086864 & & 1.0067 & 0.0013 & 4.0074 & 7.66E-14 & 0.8 & SPAO203-71 & $01 / 28 / 03$ \\
\hline
\end{tabular}




\begin{tabular}{|c|c|c|c|c|c|c|c|c|c|c|c|c|c|c|c|c|c|c|c|}
\hline Run ID\# & Sample & Materiai & $\begin{array}{l}\text { Age } \\
\text { (Ma) }\end{array}$ & $\stackrel{ \pm}{ \pm}$ & $40 / 39$ & $38 / 39$ & $37 / 39$ & $36 / 39$ & $40^{x / 39}$ & $\%$ Rad & 3 & \pm & Disc: & \pm & $\begin{array}{l}\text { Ar40 } \\
\text { (nA) }\end{array}$ & $\begin{array}{c}\text { Ar40 } \\
\text { (mols) }\end{array}$ & $\begin{array}{l}\text { Laser } \\
\text { (W) }\end{array}$ & Irrad. & Run Date \\
\hline 1456-01C & GR-15P & biotita & 959.03 & 2.49 & 80.96652 & 0.01649 & 0.00000 & 0.00002 & 80.96062 & 100.0 & 0.0086664 & $5.40 E-06$ & 1.0067 & 0.0013 & 2.5448 & $4.84 \mathrm{E}-14$ & 1.2 & SPAO203 & 3 \\
\hline 1456-01D & GR-15P & biotita & 964.24 & 2.40 & 81.33917 & 0.01545 & 0.00000 & -0.00064 & 81.52880 & 100.2 & 0.0086664 & $5.40 E-06$ & $m$ & & 3.0755 & $5.88 E-14$ & 1.7 & SPAO203-71 & $6 / 63$ \\
\hline 1456-01E & GR-15P & biotila & 963.83 & 2.36 & 81.19796 & 0.01545 & 0.00000 & -0.00097 & 81.48416 & 100 & 0.0086664 & $5.40 E-06$ & 1.0067 & 0.0013 & 3.3826 & $6.42 E-14$ & 2.2 & SPAO203-7i & $01 / 26 / 03$ \\
\hline $1456-01 \mathrm{~F}$ & GR.15P & biotita & 963.64 & 3.44 & 80.76442 & 0.01573 & 0.00000 & -0.00236 & 81.46304 & 100.9 & 0.0086664 & $5.40 E-06$ & 1.0067 & 0.0013 & 1.4015 & $2.68 E-14$ & 2.7 & SPA0203-71 & $01 / 26 / 03$ \\
\hline $1456-01 \mathrm{G}$ & GR-15P & biotita & 952.87 & 6.38 & 80.24255 & $0.015\{2$ & 0,00000 & .0 .00018 & 80.29070 & 100.1 & 0.0086664 & $5.40 E-06$ & 1.0067 & 0.0013 & 0.4154 & $7.94 \mathrm{E}-15$ & 3.7 & SPA0203-71 & $01 / 26 / 03$ \\
\hline $1456-01 \mathrm{H}$ & GR-15P & biotita & 972.83 & 5.60 & 80.56644 & 0.01155 & 0.00000 & .0 .00644 & 82.46853 & 102.4 & 0.0086664 & $5.40 E-06$ & 1.0067 & 0.0013 & 0.4895 & $9.32 E-15$ & 5.2 & SPA0203-71 & $01 / 26 / 03$ \\
\hline $1456-02 \mathrm{~A}$ & $G R-\{5 P$ & biotita & 487.33 & 9.40 & 28375 & 1768 & 00000 & 0169 & 35.78569 & 98.6 & 0.0086664 & $5.40 E-06$ & 1.0060 & 0.0013 & 0.1324 & $2.52 E-15$ & 0.3 & SPA0203-71 & $01 / 04 / 03$ \\
\hline $1456-028$ & GR-15P & biotita & 953.62 & 1.94 & 80.39355 & 0.01485 & 0.00000 & 0.00007 & 80.37267 & 100.0 & 0.0086664 & $5.40 \mathrm{E}-06$ & 1.0060 & 0.0013 & 3.6133 & $6.87 E-14$ & 0.6 & SPA0203-71 & $01 / 04 / 03$ \\
\hline $3456-02 \mathrm{C}$ & GR-15P & biobita & 967.20 & 2.00 & 81.86116 & 0.01600 & 0.00000 & 0.00003 & 81.85223 & 100.0 & 0.0086664 & $5.40 E-06$ & 1.0060 & 0.0013 & 6.2520 & $1.19 \mathrm{E}-13$ & 0.9 & SPA0203-71 & $01 / 04 / 03$ \\
\hline $1456-02 \mathrm{D}$ & GR-15P & biolita & 972.53 & 2.04 & 82.35827 & 0.01572 & 0.00000 & -0.00026 & 82.43523 & 100.1 & 0.0086664 & $5.40 E-06$ & 1.0060 & 0.0013 & 5.0046 & 9.57 & 1.2 & SPA0203-71 & $01 / 04 / 03$ \\
\hline$\{456-02 E$ & GR-15P & biolita & 976.78 & 2.29 & 82.69342 & 0.01516 & 0.00000 & -0.00070 & 82.90141 & 100.3 & 0.0085664 & $5.40 E-06$ & 1.0060 & 0.0013 & 4.0080 & $7.63 E-14$ & 1.6 & SPA0203.71 & $01 / 04 / 03$ \\
\hline $1456-02 F$ & GR-15P & biobita & 975.97 & 1.77 & 82.85777 & 0.01586 & 0.00000 & 0.00015 & 82.81283 & 99.9 & 0.0086664 & $5.40 E-06$ & 1.0060 & 0.0013 & 4.5077 & $8.60 E-14$ & 2.0 & SPA0203-71 & $01 / 04 / 03$ \\
\hline $1456-02 G$ & GR-15P & biotita & 972.72 & 2.10 & 82.22413 & 0.01498 & 0.00000 & -0.00079 & 82.45629 & 100.3 & 0.0086664 & $5.40 \mathrm{E}-06$ & 1.0060 & 0.0013 & 6.1528 & 1.17 & 27 & SPA0203-71 & $01 / 04 / 03$ \\
\hline $1456-02 \mathrm{H}$ & GR-15P & biolita & 968.77 & 1.88 & 81.96036 & 0.01575 & 0.00000 & .0 .00021 & 82.02341 & 100.1 & 0.0086664 & $5.40 \mathrm{E}-08$ & 1.0060 & 0.0013 & 4.9208 & 4 & 3.8 & 3.71 & $104 / 03$ \\
\hline $\mid 456-021$ & GR-15P & biolita & 966.06 & 4.62 & 80.70438 & 0.01328 & 0.00000 & -0.00346 & 81.72705 & 101.3 & 0.0086664 & $5.40 E-06$ & 1.0060 & 0.0013 & 0.7754 & 1.47E-14 & 5.2 & SPA0203-71 & $01 / 04 / 03$ \\
\hline $1456-0$ & -1 & iotita & 951.02 & 213 & .19435 & 1661 & 0.00000 & 0.00035 & 0.09095 & 99 & & 6 & 1.0053 & .0013 & 5.8987 & 1.13E-13 & 0.6 & 71 & 103 \\
\hline $1456-038$ & GR-15P & biobita & 965.20 & 2.14 & 81.72264 & 0.01623 & 0.00000 & 0.00030 & 81.63356 & 99.9 & 0.0086664 & $5.40 \mathrm{E}-06$ & 1.0053 & 0.0 & & & 0 & & 103 \\
\hline $1456-03 \mathrm{C}$ & GR-15P & biotita & 968.27 & 2.50 & $8\{.73304$ & 0.01571 & 0.00075 & -0.00080 & 81.96896 & 100.3 & 0.0086664 & $5.40 E-06$ & 1.0053 & 0.0013 & 62 & & 1.2 & SPA & $01 / 27 / 03$ \\
\hline $1456-030$ & GR-15P & biotita & 963.59 & 2.24 & 81.52940 & 0.01647 & 0.02376 & 0.00025 & 81.45716 & 99.9 & 0.00 & $5.40 E-06$ & 1.0053 & 0.0013 & 5.3894 & 1.03 & 1.7 & SPA0203-71 & $01 / 27 / 03$ \\
\hline$\$ 456-03 E$ & GR-15P & biofita & 963.09 & 1.8 & 81.49 & 0.01655 & 0.02129 & 0.00033 & 81.40256 & 99.9 & 0.00 & $5.40 \mathrm{E} \cdot 06$ & 1.0053 & 0.0013 & 4.8803 & 9.36 & 2.3 & SPA0203-?1 & $01 / 27 / 03$ \\
\hline $1456-03 F$ & GR-15P & biotita & 958.52 & 5.15 & 80.60035 & 0.01568 & 0.15336 & -0.00096 & 80.90505 & 100.4 & 0.0086664 & $5.40 \mathrm{E}-06$ & 1.0053 & 0.0013 & 0.6012 & & & & $01 / 27 / 03$ \\
\hline $1456-03 \mathrm{G}$ & GR-15P & biotita & 962.14 & 6.09 & 81.20864 & 0.02136 & 0.42699 & -0.00011 & 81.29892 & 100.1 & 0.0086664 & $5.40 E-06$ & 1.0053 & 0.0 & 0.5 & & 3.7 & 3-71 & $01 / 27 / 03$ \\
\hline $\begin{array}{l}3456-03 H \\
x_{2}\end{array}$ & GR-15P & biotita & 939.71 & 12.21 & 80.69901 & 0.02879 & 0.07556 & 0.00623 & 78.86880 & 97.7 & 0.0086664 & $5.40 E-06$ & 1.0053 & 0.0013 & 0.2313 & 4.41E-15 & 5.2 & SPA0203-71 & 0127103 \\
\hline $1458-01 \mathrm{~A}$ & A.746 & biotita & -458.64 & 296.84 & 10.21137 & .0 .02132 & 0.31810 & 0.1222 & -25.90281 & $\%-253.6$ & & $5.40 \mathrm{E}-06$ & & & & & & & \\
\hline $1458-01 \mathrm{~B}$ & A. -746 & biotita & -3.68 & 3.27 & 2.26423 & 0.01776 & 0.05493 & 0.00847 & .0 .23545 & -10.4 & 0.0086664 & $5.40 E-06$ & $\begin{array}{l}1.0060 \\
1.0060\end{array}$ & $\begin{array}{l}0.0013 \\
0.0013\end{array}$ & $\begin{array}{l}0.0013 \\
0.0196\end{array}$ & $\begin{array}{l}2.26 E-17 \\
3.72 E-16\end{array}$ & 0.3 & $33-71$ & $01 / 04 / 03$ \\
\hline $1458-01 \mathrm{C}$ & A. 746 & tia & 23.16 & 0. & 1.78766 & 0.01277 & 0.00000 & 0.00100 & 1.49070 & 83.4 & & & & & & & 0.6 & & $1 / 03$ \\
\hline 1458-01D & A. 746 & & 22.47 & 0.39 & 1.68625 & 01287 & 0.01420 & 0.00 & 1.4 & $8 t$ & & 5.40 & 1.0060 & 0.0013 & 0.13 & & 0.9 & $3-71$ & $01 / 04 / 03$ \\
\hline 1458-01E & A. 746 & & 22. & 0.29 & 1.61890 & 308 & 0.00 & 0.00 & 1.4474 & 89 & & 5.40 & 1.0060 & 0.6 & 77 & & 1.2 & $3-71$ & $01 / 04 / 03$ \\
\hline & A.7. & & 21 & & 1.57995 & 1343 & 014 & 14 & & 86.2 & & & 1.0 & 0.0013 & 0.1242 & & 1.6 & $3-71$ & $01 / 04 / 03$ \\
\hline $1458-01 G$ & A.746 & otita & 20.27 & 0. & 3. & 0.01324 & 44 & 80 & 1.30395 & 84.7 & 0.00 & 5.40 & & 0.0 & 0.1 & & .0 & & $\begin{array}{l}01104 / 03 \\
010403\end{array}$ \\
\hline $1458-01 \mathrm{H}$ & A.746 & sa & 21.53 & 0.17 & 1.48929 & 0.01315 & 0.00111 & 0.00035 & 1.38554 & 93. & & & 1.0 & 0.00 & 0 & & 2.7 & -71 & 01104103 \\
\hline $1458-011$ & A.746 & biotita & 20.05 & 0.46 & 1.46219 & 0.01342 & 0.00000 & 0.00058 & 1.28924 & 88.2 & 0.0086664 & $5.40 E-06$ & 1.0060 & 0.0013 & 0.0880 & $1.66 \mathrm{E}-15$ & $\begin{array}{l}5.2 \\
5.2\end{array}$ & $\begin{array}{l}\text { SPA0203-71 } \\
\text { SPA0203-71 }\end{array}$ & $\begin{array}{l}01 / 04 / 03 \\
01 / 04 / 03\end{array}$ \\
\hline & & & & & & & & & & & & & & & & & & & \\
\hline 1458 & A. & & 22. & & & 58 & & & 1.45038 & 97.3 & 0.00 & 5.40 & 1.0053 & 0.0013 & 0.1693 & & 1.3 & $33-71$ & $01 / 27 / 03$ \\
\hline $1458.02 \mathrm{C}$ & A-1 & & 22 & & 1.45823 & 0.01280 & 0.00000 & & 1.45793 & 100.0 & & 5.40 & 1.0053 & 0.0013 & & & 1.7 & $3-71$ & $04 / 27 / 03$ \\
\hline & & & 21.98 & 0.30 & 1.49499 & 0.01290 & 0.01363 & & 1.4 & 94 & & & & & & & 2. & 71 & $01 / 27 / 03$ \\
\hline $1458-02 E$ & A-746 & & 20.37 & 0. & & 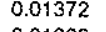 & & & & & & & & & 0.8 & 9. & 3 & 71 & $01 / 27 / 03$ \\
\hline & A. 74 & & 23.6 & 1.55 & & 23 & & & 1.53922 & 103.6 & & $5.40 E \cdot 06$ & 1.0053 & 0.0013 & 0.0 & & & & \\
\hline $1458-02 G$ & A.746 & iotita & 20.08 & 12.27 & 1.22129 & 0.01764 & 0.00000 & .0 .00024 & 1.28144 & 105.8 & 0.0086664 & $5.40 E-06$ & 1.0053 & 0.0013 & 0.0030 & $5.69 \mathrm{E}-17$ & 5.2 & SPAO203-71 & $01 / 27103$ \\
\hline & & & & & & & & & & & & & & & & & 0.8 & & \\
\hline $1458-0$ & A.7 & & 22 & 0.7 & & 1227 & & & & & & & & & 0.0 & 1.1 & 1.4 & -71 & $01 / 27 / 03$ \\
\hline & A- & & & 0. & & & & & & 96.7 & & 5.40 & 1.0053 & 0.0013 & 0.0479 & 9.1 & & $3-71$ & \\
\hline & & & & & & & & -0.00143 & 1.84033 & 130.5 & 0.0086664 & 5.40 & 10 & 0.0013 & & & 2.8 & SPAOZ & $01 / 27 / 03$ \\
\hline & & & & 1 & & -0.0 & ( & & 4.73545 & 309.6 & & & 1.0 & & & & 3.8 & $S P A$ & $01 / 27 / 03$ \\
\hline 8-03F & A-746 & & 8.10 & 77 & 10703 & -0.03917 & 0.00000 & -0.03679 & 11.97220 & & 0.0086664 & $5.40 \mathrm{E}-06$ & 1.0053 & 0.0013 & 0.0010 & $2.13 E-17$ & 5.2 & SPA0203-71 & $01 / 27 / 03$ \\
\hline
\end{tabular}


